
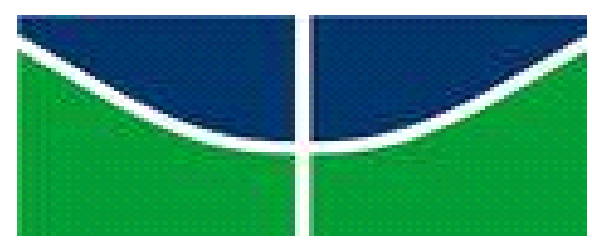

UNIVERSIDADE DE BRASÍLIA

INSTITUTO DE CIÊNCIAS HUMANAS - IH

DEPARTAMENTO DE SERVIÇO SOCIAL - SER

PROGRAMA DE PÓS-GRADUAÇÃO EM POLÍTICA SOCIAL - PPGPS

\title{
POLÍTICAS PÚBLICAS PARA IDOSOS NO BRASIL: Análise à luz da influência das Normativas Internacionais
}

\author{
Jurilza Maria Barros de Mendonça
}

Orientadora: Prof. Dra. Potyara Amazoneida Pereira Pereira

Tese de Doutorado

Brasília-DF, março de 2015 
Mendonça, Jurilza Maria Barros de

Políticas públicas para idosos no Brasil: análise à luz da influência das Normativas Internacionais / Jurilza Maria Barros de Mendonça, 2015.

172 f. : II.

Tese de Doutorado. Departamento de Serviço Social - Universidade de Brasília, Brasília, 2015

1. Serviço Social, envelhecimento, dependência, cuidado, pessoa idosa. I. Universidade de Brasília SER. II. Título.

CDU 360

É concedida à Universidade de Brasília permissão para reproduzir cópias desta tese e emprestar ou vender tais cópias somente para propósitos acadêmicos e científicos. A autora reserva outros direitos de publicação e nenhuma parte desta tese de doutorado pode ser reproduzida sem a autorização por escrito da autora. 


$$
\begin{gathered}
\text { UNIVERSIDADE DE BRASÍLIA } \\
\text { INSTITUTO DE CIÊNCIAS HUMANAS - IH } \\
\text { DEPARTAMENTO DE SERVIÇO SOCIAL - SER }
\end{gathered}
$$

PROGRAMA DE PÓS-GRADUAÇÃO EM POLÍTICA SOCIAL - PPGPS

\title{
POLÍTICAS PÚBLICAS PARA IDOSOS NO BRASIL: Análise à luz da influência das Normativas Internacionais
}

\author{
Jurilza Maria Barros de Mendonça
}

Tese de Doutorado apresentada ao Programa de Pós-Graduação em Política Social do Departamento de Serviço Social da Universidade de Brasília, como requisito parcial à obtenção do título de Doutora em Política Social.

Banca examinadora

Potyara Amazoneida P. Pereira, Professora Doutora (Departamento de Serviço Social SER/UnB)

Orientadora

Rosa Helena Stein, Professora Doutora (Departamento de Serviço Social - SER/UnB) Membro 
Maria Cecília de Sousa Minayo, Professora Doutora (Centro Latino-Americano de Estudos de Violência e Saúde Jorge Careli - CLAVES/FIOCRUZ)

Membro-Externo

Ana Amélia Camarano Moreira, Professora Doutora (Instituto de Estudos e Pesquisa Aplicada - IPEA)

Membro externo

Paulo Roberto Barbosa Ramos, Professor Doutor (Universidade Federal do Maranhão UFMA)

Membro externo

Maria Auxiliadora César, Professora Doutora (Núcleo de Estudos Cubanos NESCUBA/CEAM/UnB)

Suplente Membro interno 
Aos meus filhos,

Victor, Vinícius e Micheline À memória de meu marido Ernesto 


\section{AGRADECIMENTOS}

À minha orientadora, Professora Dra. Potyara Amazoneida Pereira Pereira, pela incessante dedicação, socialização de conhecimentos, orientação e incentivo para seguir em frente mergulhando na política social;

Ao Professor Gregório Rodriguez Cabrero, pela coorientação no período em que realizei o doutorado-sanduíche na Universidade de Alcalá de Henares - España, pela condução ao conhecimento e à pesquisa sobre dependência e cuidados e pela facilitação ao acesso a instituições públicas e privadas de atenção às pessoas idosas dependentes;

À Dra. Ana Amélia Camarano, pela participação na minha banca de qualificação do Projeto de Tese e pela sugestão de mudança da unidade de análise empírica da pesquisa: substituir política de previdência pelo trato da dependência e dos cuidados às pessoas idosas - um tema ainda pouco conhecido e trabalhado no Brasil;

Às Professoras Dras. Maria Cecília Minayo e Maria Auxiliadora César, pelas orientações oferecidas no exame de qualificação do Projeto; à Dra. Elizabeth Hernandes Cangliari, pela participação na suplência deste Exame;

Ao Professor Dr. Paulo Roberto Barbosa Ramos, pela aceitação em compor a Banca de Defesa desta Tese;

À Professora Dra. Rosa Helena Stein, pelo incentivo e pela indicação dos caminhos de acesso à Universidade de Alcalá de Henares - Espanha e pela aceitação em compor a Banca de Defesa desta Tese;

À Professora Dra. Silvia Cristina Yannoulas, coordenadora de Pós-Graduação PPGPS/SER/IH/UnB, pelo apoio à pesquisa no doutorado-sanduíche.

À Coordenação de Aperfeiçoamento de Pessoal de Nível Superior (CAPES), pelo apoio institucional e financiamento do doutorado-sanduíche (PDSE);

À secretária do Programa de Pós-graduação em Política Social da UnB, Domingas Carneiro, pela permanente disposição em agilizar processos e em dirimir dúvidas.

Às amigas Izabel Pessoa e lone Medeiros, pelo apoio e incentivo à pesquisa;

À amiga Camila Potyara Pereira, pelas informações e incentivo referentes à minha participação no doutorado-sanduíche;

Aos amigos Marcelo Antonio Salgado, Vitória Góis de Araújo, Sérgio Márcio Pacheco Paschoal, Emídio Rebelo Filho, Edusa César, Sérgio Antonio Carlos, Emanuel Dantas, Sandra Mallet e Elizabeth Hernandes, pela contribuição e pelos depoimentos para este trabalho; 
Aos amigos Miguel Ángel Vazquez Vazquez, Eulalia Cucurella, Antonio Yuste, pelos conhecimentos fornecidos sobre os serviços destinados aos idosos dependentes nas regiões da Galícia e da Catalunia/Espanha;

Aos Conselhos de Defesa dos Direitos do Idoso dos Estados do Amazonas, Amapá, Acre, Distrito Federal, Goiás, Maranhão, Minas Gerais, Paraná, Pernambuco, Rio de Janeiro, Rondônia, Santa Catarina; e dos Municípios de Belo Horizonte, Cuiabá, Florianópolis, Feira de Santana, Maceió, Palmas, Recife, São Paulo, São Luís e Santos, pela colaboração, pelo apoio e pelas informações, como sujeitos da minha pesquisa de campo;

Ao meu neto João Victor, pelo apoio nas horas de aperto com o mundo da informática;

À minha irmã Sonia, pelo apoio e pela companhia no período do doutoradosanduíche. 
Os grandes empreendimentos não levam a cabo por meio de força ou velocidade ou agilidade do corpo, mas, sim, pela sabedoria, pela autoridade e pelos bons conselhos; e de todas essas qualidades, a velhice costuma não somente não estar privada, mas até ser delas provida com abundância.

Cícero 


\section{RESUMO}

Trata a presente tese das políticas sociais públicas para os idosos no Brasil à luz das normativas internacionais. Dentre estas, destacam-se às associadas aos cuidados de longa duração, como demanda premente e arena na qual se confrontam interesses diferenciados: os do Estado, os do mercado e os dos idosos em particular. O envelhecimento populacional é um processo que vem se impondo como uma realidade incontestável, sem, porém, constituir prioridade na agenda política de vários países. Nesse contexto, caracterizado por crises do capital e pela hegemonia do ideário neoliberal, a garantia de direitos da pessoa idosa vem sendo negligenciada não apenas no Brasil. É fato empírico que, tanto no chamado Terceiro Mundo, quanto no Primeiro Mundo, há - embora de forma diferenciada - crescente esvaziamento dessa garantia. E isso ocorre na contramão da seguinte tendência: com o aumento da expectativa de vida, vem aumentando significativamente o número de pessoas com 80 anos e mais de idade, sendo essa faixa etária a que apresenta maior incidência de dependência de cuidados. Tal dependência já vem sendo considerada como um "risco social", nos países desenvolvidos, que extrapola da esfera familiar para o Estado. Desde 1982, a Organização das Nações Unidas vem discutindo o envelhecimento populacional e seus impactos econômicos e sociais. Dentre as normativas internacionais, destacam-se o Plano de Madri, de 2002, e a Declaração de Brasília, de 2007, que recomendam a criação de um documento de âmbito internacional juridicamente vinculante. As discussões na Organização das Nações Unidas e na Organização dos Estados Americanos, das quais o Brasil tem feito parte, vêm avançando sobre a importância de uma Convenção dos Direitos Humanos da Pessoa Idosa. A pesquisa realizada revela a ausência de mecanismos que exijam o cumprimento de legislações que assegurem os direitos das pessoas idosas; a falta de compromisso político por parte dos gestores em implementar as legislações existentes; e a precariedade do controle democrático eficiente em fazer com que as legislações sejam cumpridas.

Palavras-chaves: envelhecimento; dependência; cuidado; pessoa idosa. 


\begin{abstract}
This thesis analyzes public social policies for the elderly in Brazil, considering the international agreements. There are the policies associated with long-term care as an urgent demand and arena in which to confront state interests, the market and in particular the elderly. Population aging is a process which has been growing as an undeniable reality, without, however, the proper inclusion on the political agenda of many countries. In this context, characterized by crises of capital and hegemony of neoliberal ideas, the elder guarantee of rights has been overlooked. It is an empirical fact that the there has been an increasing emptying of the rights of the elderly in the First and Third World. And this is counter to the following trend: with increasing life expectancy, has been significantly increasing the number of people aged 80 and older, which is the group that has the highest incidence of dependency care. This dependency is already considered as a "social risk" in developed countries, which goes beyond the family sphere to the state. Since 1982, the United Nations has discussed the aging population and its economic and social impacts. Among the international agreements, we highlight the Madrid Plan of 2002 and the Brasilia Declaration of 2007, which recommended the creation of an international framework document that is legally binding. The discussions at the United Nations and the Organization of American States, of which Brazil has been part, is advancing on the importance of a Convention on Human Rights of the elderly. At the end, this survey reveals: the absence of mechanisms that require compliance with laws that ensure the rights of older people, lack of political commitment from government to implement the existing legislation and the precariousness of effective democratic control in making the laws effective.
\end{abstract}

Keywords: aging; dependency; care; elder. 


\section{RESUMÉ}

La thèse aborde les politiques sociales publiques pour les personnes âgées au Brésil, à la lumière des normes internationales. Parmi celles-ci, on peut mettre en évidence les normes associées aux soins de longue durée qui constituent une demande pressante où s'affrontent des intérêts distincts, de l'État, du marché et des personnes âgées au niveau particulier. Le vieillissement de la population est un processus qui s'impose comme une réalité incontestable, même s'il ne constitue pas une priorité dans l'agenda politique de nombreux pays. Dans un contexte caractérisé par des crises du capital et une hégémonie des idées néolibérales, les garanties des droits des personnes âgées sont laissées au second plan, et pas seulement au Brésil. Aussi bien dans le tiers-monde que dans les pays développés, il est possible de constater de manière empirique un recul croissant de ces garanties, encore que de manières différentes. Avec l'allongement de l'espérance de vie, cette tendance va à contresens de l'augmentation significative du nombre de personnes de 80 ans et plus, à un âge où elles dépendent le plus de soins. Cette dépendance est d'ores et déjà considérée un "risque social» dans les pays développés, qui dépasse les limites de la sphère familiale pour devenir la responsabilité de l'État. Depuis 1982, les Nations Unies organisent des débats au sujet du vieillissement de la population et de ses impacts économiques et sociaux. Parmi les normes internationales, on peut mentionner le Plan de Madrid de 2002 et la Déclaration de Brasília de 2007, qui recommandent l'établissement d'un document de portée internationale juridiquement contraignant. Aux Nations Unies et à l'Organisation des États Américains, dont le Brésil fait partie, les discussions progressent quant à l'importance d'une Convention des droits humains des personnes âgées. La recherche menée révèle l'absence de mécanismes obligeant l'application de législations qui garantissent les droits des personnes âgées; le manque d'engagement politique de la part des responsables pour la mise en œuvre des lois existantes; et la précarité d'un contrôle démocratique efficace pour l'application de ces lois.

Mots-clés: vieillissement; dépendance; soins; personnes âgées. 


\section{RESUMEN}

La presente tesis trata de la políticas sociales públicas para las personas mayores en Brasil considerando las normativas internacionales. Entre esas se destacan las asociadas a los cuidados de larga duración como demanda urgente y la zona en la cual se confrontan intereses diferenciados: del Estado, del mercado y de los mayores en particular. El envejcimiento poblacional es un proceso que se impone como una realidad incontestable, sin, todavía, componer prioridad en la agenda política de vários países. En ese contexto, caracterizado por la crisis del capital y la hegemonía del neoliberalismo, la garantía de los derechos de la persona mayor está descuidado no solamente en Brasil. Es un hecho empírico que tanto en el llamado Tercer Mundo cuanto en el Primero, hay un creciente agotamiento de esa garantía, aunque de forma diferenciada. Eso ocurre en dirección contraria a la siguiente tendencia: con el aumento de la expectativa de vida, hay un aumento significativo en el número de personas con 80 años o más de edad, y ese grupo de edad que presenta mayor incidencia de dependencia de cuidados. Tal dependenca ya es considerada un "riesgo social" en los países desarrollados, que extrapola la esfera familiar para el Estado. Desde 1982 las Naciones Unidas discute el envejecimiento poblacional y sus impactos económicos y sociales. Entre las normativas internacionales, se destacan el Plan de Madrid de 2002 y la Declaración de Brasília de 2007, que recomiendan la creación de un documento de ámbito internacional que sea juridicamente obligatorio. Las discusiones en las Naciones Unidas y en la Organización de los Estados Americanos, las cuales Brasil es participante, se avanza la importancia de una Convención de los Derechos Humanos de la persona mayor. Esa investigación revela: la ausencia de mecanismos que exijam el cumplimiento de las legislaciones que aseguren los derechos de las personas mayores; la falta de compromiso político por parte de los gestores en implementar las legislaciones existentes; y la precariedad del control democrático eficiente en hacer con que las legislaciones sean cumplidas.

Palabras clave: envejecimiento; dependencia; cuidado; persona mayor.. 


\section{LISTA DE SIGLAS}

ACEPI - Associação Cearence Pró-Idosos

AICP - Atenção Centrada na Pessoa

ASIPA - Asistencia a Personas Mayores

ASSISPA - Associação dos Idosos do Pará

ANG - Associação Nacional de Gerontologia

ANFIP - Associação Nacional dos Auditores-Fiscais da Receita Federal

AVDs - Atividades de Vida Diária

AIVDs - Atividades Instrumentais de Vida Diária

CAPs - Caixas de Aposentadorias e Pensões

CCAA - Comunidades Autônomas

CEI - Conselho Estadual do Idoso

CEPAL - Comissão Econômica para América Latina e Caribe

CLD - Cuidados de Longa Duração

CNBB - Confederação Nacional dos Bispos do Brasil

CEME - Central de Medicamentos

CNDI - Conselho Nacional dos Direitos do Idoso

COBAP - Confederação Brasileria dos Aposentados, Pensionistas e Idosos

CONTAG - Confederação dos Trabalhadores da Agricultura

CRAS - Centro de Referência de Assistência Social

CREAS - Centro de Referência Especializada de Assistência Social

CUT - Central Única de Trabalhadores

DATAPREV - Empresa de Processamentos de Dados da Previdência Social

DESC - Direitos Econômicos, Sociais e Culturais

EBE - Estado de Bem-Estar

El - Estatuto do Idoso

FNI - Fundo Nacional do Idoso

FUNABEM - Fundação Nacional do Bem-estar do Menor da Previdência Social

GIE - Grupo Interagencial sobre Envelhecimento

IAPAS - Instituto de Administração Financeira da Previdência e Assistência Social 
INAMPS - Instituto Nacional de Assistência Médica e Assistência Social

IAPC - Instituto de Aposentadorias e Pensões dos Comerciários

IAPB - Instituto de Aposentadorias e Pensões dos Bancários

IAPETEC - Instituto de Aposentadorias e Pensões dos Trabalhadores e Empregadores de Cargas

IAPM - Instituto de Aposentadorias e Pensões dos Marítimos

IBGE - Instituto Brasileiro de Geografia e Estatística

ILPI - Instituição de Longa Permanência para Idosos

IMSERSO - Instituto de Mayores y Servicio Social

IPEA - Instituto de Pesquisa Econômica Aplicada

IPASE - Instituto de Aposentadorias e Pensões dos Servidores do Estado

IAP - Instituto de Aposentadorias e Pensões

INPS - Instituto Nacional de Previdência Social

LAPAD - Lei da Autonomia y Atención a las Personas en Situación de Dependencia

LBA - Legião Brasileira de Assistência

LOAS - Lei Orgânica da Assistência Social

MDS - Ministério do Desenvolvimento Social e Combate à Fome

MOSAP - Movimento Nacional dos Servidores Públicos Aposentados e Pensionistas

OCDE - Organização para Cooperação e Desenvolvimento Econômico

OEA - Organização dos Estados Americanos

OMS - Organização Mundial de Saúde

ONU - Organização das Nações Unidas

OISS - Organização Iberoamericana de Seguridade Social

OPS - Organização Panamericana de Saúde

PEC - Projeto de Emenda Constitucional

PIA - Plano Individual de Atenção

PIB - Produto Interno Bruto

PNAD - Pesquisa Nacional por Amostra de Domicilio

PNI - Política Nacional do Idoso

PNSPI - Política Nacional de Saúde da Pessoa Idosa

PSF - Programa Saúde da Família 
RIICOTEC - Red Intergubernamental Iberoamericana de Cooperación Técnica en el área de Personas Mayores y con Discapacidad

SBGG - Sociedade Brasileira de Geriatria e Gerontologia

SCFV - Serviço de Convivência e Fortalecimento de Vínculos

SDH - Secretaria de Direitos Humanos

SEDH - Secretaria Especial de Direitos Humanos

SESC - Serviço Social do Comércio

SAD - Serviço de Atenção Domiciliar

SAAD - Sistema de Autonomia y Atención a las Personas en Situación de Dependencia

UDP - Unión Democrática de Pensionados y Jubilados

UAH - Universidade de Alcalá de Henares

UGT - União Geral de Trabalhadores

UNICEF - Fundo das Nações Unidas para a Infância

UNFPA - Divisão de População das Nações Unidas 


\section{LISTA DE TABELAS E GRÁFICOS}

Quadro 1 - Modelos europeus de cuidados de larga duración p. $64-65$

Quadro 2 - Comité de Derechos Económicos, Sociales Y Culturales: contenidos de la Observación General № 6 ..p. 73 


\section{Sumário}

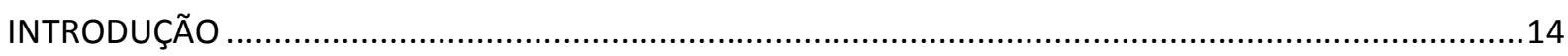

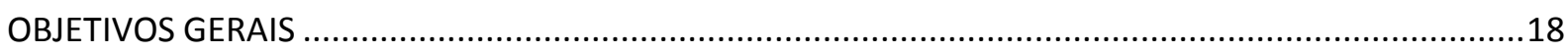

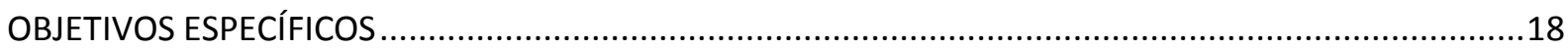

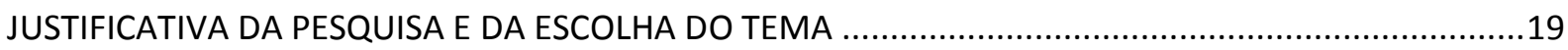

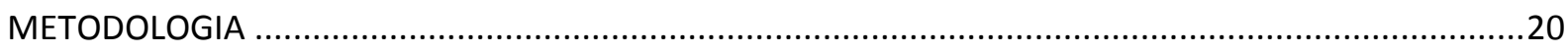

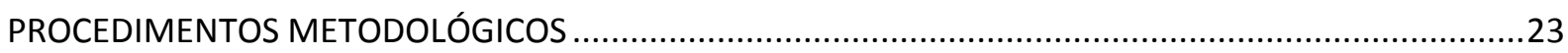

1 ENVELHECIMENTO E CONCEITOS CORRELATOS REVISANDO A LITERATURA ESPECIALIZADA ......27

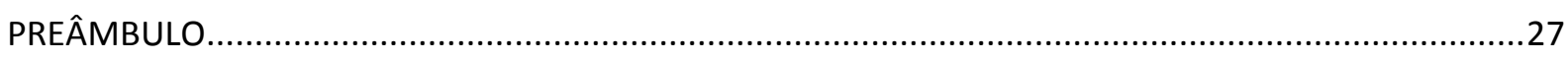

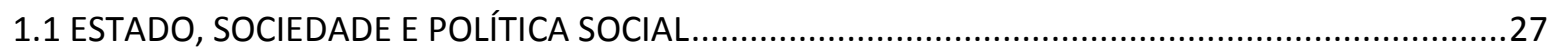

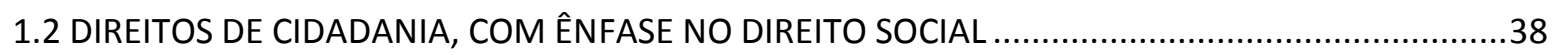

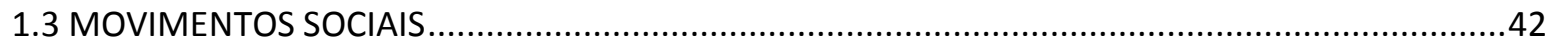

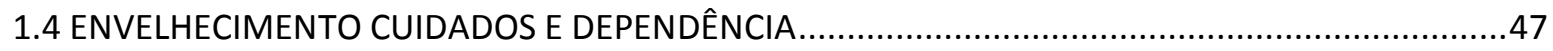

2 CAPITALISMO EM CRISE E POSSIBILIDADES DAS POLÍTICAS PÚBLICAS PARA O ENVELHECIMENTO:

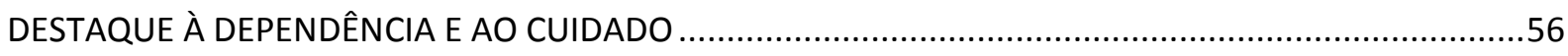

2.1 ASCENSÃO E CRISE DO ESTADO SOCIAL NO CAPITALISMO DOS ÚLTIMOS SETENTA ANOS..56

2.2 O SISTEMA DE ASSISTÊNCIA À PESSOA IDOSA DEPENDENTE NA CONJUNTURA DA CRISE

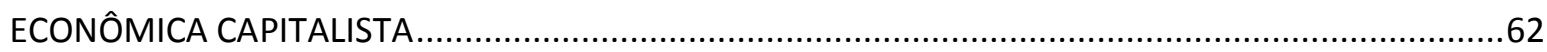

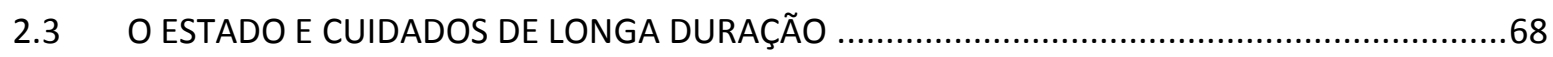

3 POLÍTICA DE CRIAÇÃO DE GARANTIAS FORMAIS DOS DIREITOS DOS IDOSOS EM ÂMBITO

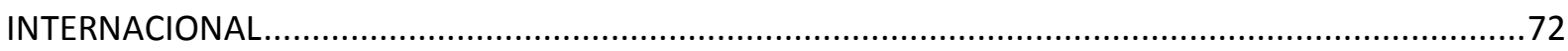

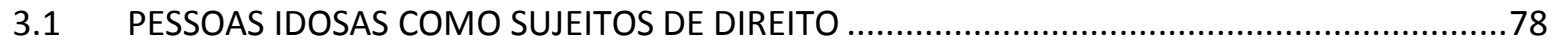

3.2 DISPONIBILIDADE DOS SISTEMAS DE APOIO SOCIAL ÀS PESSOAS IDOSAS ..........................78

3.3 IGUALDADE DOS SISTEMAS DE APOIO SOCIAL DAS PESSOAS IDOSAS …...........................79

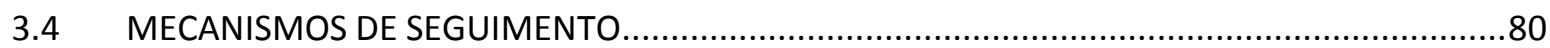

4 EVOLUÇÃO E TENDÊNCIAS DAS NORMATIVAS E POLÍTICAS DE PROTEÇÃO AO IDOSO NO BRASIL

4.1 CONTROLE DEMOCRÁTICO COMO INSTRUMENTO DE DEMOCRACIA DIRETA ...................116

5 SERVIÇOS DE ATENÇÃO ÀS PESSOAS IDOSAS DEPENDENTES ................................................121 
5.1 SERVIÇOS DESTINADOS AOS CUIDADOS DE LONGA DURAÇÃO NA ESPANHA ....................121

5.2 DEPENDÊNCIA E CUIDADO NO CONTEXTO ESPANHOL.................................................124

5.3 INSTITUIÇÕES NÃO GOVERNAMENTAIS QUE DESENVOLVEM AÇÕES EM PROL DAS PESSOAS

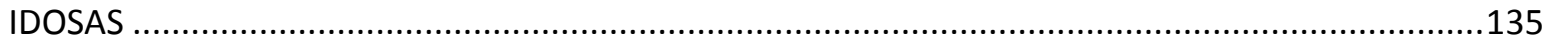

5.4 SEGURO-CUIDADO E A QUESTÃO DO FINANCIAMENTO ….............................................139

5.5 SERVIÇOS DESTINADOS AOS CUIDADOS DE LONGA DURAÇÃO NO BRASIL ........................144

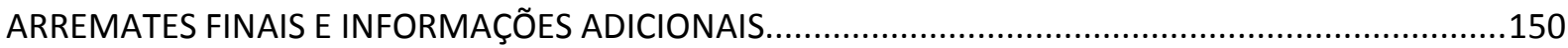

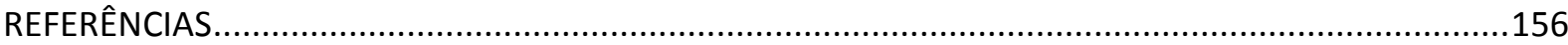

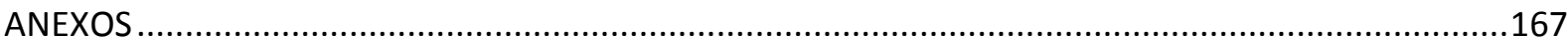

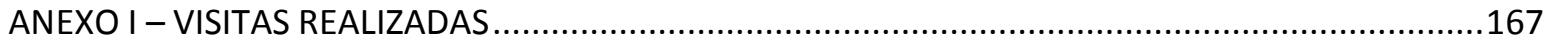

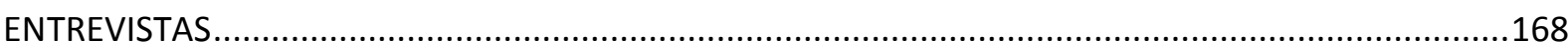




\section{INTRODUÇÃO}

Seguindo tendência internacional, o envelhecimento populacional vem-se impondo nos países em desenvolvimento como uma realidade incontestável. Todavia, observa-se que o governo e a sociedade brasileira não tratam essa realidade como um fato prioritário e emergente, o que explica a inexistência, na agenda política nacional, de uma discussão consistente sobre a velhice que inclua a efetivação dos direitos dos idosos, especialmente os sociais.

Embora o Brasil tenha instituído a Política Nacional do Idoso, as condições de vida e de cidadania da população idosa são precárias, uma vez que as políticas públicas destinadas a esse segmento não têm conseguido atender às suas necessidades mais vitais. Daí, é necessário ampliar a discussão sobre a criação de uma Convenção Internacional dos Direitos dos Idosos na perspectiva de reforçar a efetividade da implementação dessas políticas e a sua possibilidade de concretizar direitos previstos legalmente. Como afirma Bobbio (2004, p. 40), "o Estado de direito é aquele que funciona regularmente como um sistema de garantia dos direitos do homem".

O sistema de garantia dos direitos dos idosos no Brasil tem sido negligenciado. O país possui uma legislação que, em tese, contempla a garantia de ampla cobertura à população idosa; porém, prevalece a não efetivação dos direitos nela previstos, direitos esses que deveriam ser concretizados por políticas sociais públicas e controlados democraticamente pela sociedade, incluindo o seu público-alvo, até porque, dado o acelerado processo de envelhecimento populacional, as questões que permeiam a velhice tornam-se urgentes.

Além disso, com o aumento da expectativa de vida, também está aumentando significativamente a população brasileira acima dos oitenta anos de idade. Em 2000, segundo dados do Censo realizado pelo Instituto Brasileiro de Geografia e Estatística IBGE, existiam, no país, 1.832 .105 pessoas com 80 anos e mais de idade; mas esse número saltou para 2.935.558 no Censo de 2010, dos quais 1.133 .112 eram homens e 1.802.446, mulheres. E mais, mostram que já são 24.210 centenários, sendo 2/3 mulheres.

Esse contingente é constituído, na maior parte, por pessoas que apresentam não só incidência de enfermidades crônicas, mas também como diminuição de capacidade funcional e de autonomia, exigindo maiores cuidados em razão da dependência. As mulheres, cuja proporção é de 100 para cada 63 homens, são as que mais apresentam limitações relacionadas à saúde.

A maioria dos governantes demonstra não ter despertado para o impacto que o envelhecimento terá sobre a eficiência e a eficácia das políticas sociais. Essa atitude agrava a situação descrita porque impede o desenvolvimento de ações de prevenção de doenças e 
de promoção da saúde das pessoas idosas, que solicitam: rede de proteção e defesa dos direitos, com serviços em centros-dia; centros de convivência; instituições de longa permanência; atenção domiciliar; centros de saúde e reabilitação; centros de apoio de assistência social, dentre outros.

Até o momento, têm sido considerados apenas os impactos do envelhecimento na Previdência Social, o que torna imperiosa a luta dos movimentos sociais por uma ampla atenção ao idoso por intermédio de serviços, programas e projetos intersetoriais de qualidade e desmercadorizados.

A magnitude das mudanças sociais provocadas pelos determinantes estruturais e históricos do envelhecimento populacional, que fazem deste um novo eixo de pressão sobre o Estado, requer investimentos significativos nas políticas públicas. Entre estas, ressaltamse as que repercutem no âmbito econômico, no mercado de trabalho, nas aposentadorias e pensões (contributivas e não contributivas), e nos sistemas de saúde, educação, habitação, transporte, lazer e relações intergeracionais.

Dada a prevalência desse padrão ainda limitado de cidadania na realidade brasileira, elegeu-se como objeto de interesse desta tese as políticas sociais públicas para os idosos no Brasil contemporâneo vis-à-vis a influência das decisões acordadas nos eventos internacionais sobre a construção de um marco legal supranacional. Dentre essas políticas públicas, foram enfatizadas as associadas aos cuidados de longa duração, como uma arena na qual se confrontam interesses diferenciados: os do Estado, os do mercado e os dos idosos a que delas fazem jus. O período investigado situa-se entre os anos 2002 e 2013.

Embora, nesta pesquisa, tenha-se dado ênfase aos cuidados de longa duração, foi observado o caráter transversal e contextualizante do tema do envelhecimento, o qual requer ações intersetoriais de diversas áreas, como saúde, assistência social, previdência social, esporte, cultura, dentre outras, com vista a uma proteção social integral. Assim, não se pôde deixar de considerar o comprometimento do Estado e da sociedade com o bemestar integral dos idosos, pois o desenvolvimento de ações previstas nas legislações existentes depende do poder de pressão de setores organizados da sociedade e da vontade política dos governantes. Isso ocorre em virtude de:

[...] embora a política pública seja regulada e frequentemente provida pelo Estado, ela também engloba demandas, escolhas e decisões privadas, podendo (e devendo) ser controlada pelos cidadãos. Isso é o que se chama de controle democrático (PEREIRA, 2008, p.174).

O controle democrático das políticas destinadas às pessoas idosas, conforme previsto na Constituição Federal vigente, promulgada em 1988, pode ser exercido por vários canais institucionais de participação política direta, tais como o plebiscito, o referendo e a iniciativa 
popular; mas são os Conselhos de Defesa de Direitos da Pessoa Idosa, existentes nas três esferas de Governo (União, estados e municípios, além do Distrito Federal), que devem exercitar regularmente essa tarefa. Porém, observa-se que esses canais têm sido pouco efetivos no seu papel de zelar pela garantia dos direitos dos idosos. Entre os aspectos que concorrem para essa situação é a fragilidade da correlação de forças entre sociedade civil e Estado no âmbito dos referidos Conselhos. No atual estágio de desenvolvimento capitalista, regido pelo ideário neoliberal, que privilegia a acumulação do lucro privado, as pessoas idosas são vistas como um peso para a sociedade e para os governos, apesar de haver comprovação de que cerca de $64,2 \%$ dessas pessoas contribuem com a renda total das famílias brasileiras.

Nesse contexto, é de interesse desta pesquisa analisar, à luz da legislação internacional, não só em que medida o processo de institucionalização das políticas sociais públicas para os idosos, em especial a Política Nacional do Idoso, criada no país em 1994, efetiva, no âmbito dos cuidados, os direitos sociais desse segmento, contidos no Estatuto do Idoso (EI), de 2003, mas também se o El tem sido acionado como um mecanismo capaz de levar à punição quem fere esses direitos. Cabe também averiguar se esses dois institutos legais preveem e garantem de fato a realização de serviços, de programas e de projetos de forma intersetorial e descentralizada.

Tal interesse assenta-se na compreensão de que as políticas sociais públicas não se dão de forma acéfala, espontânea e intuitiva. Pelo contrário, elas obedecem a uma espécie de ciclo vital, cujas etapas procedimentais de análise, no dizer de Moreno (2000), podem ser assim descritas: a fixação de uma agenda de atuação, a identificação do problema a enfrentar e a previsão das fases de tomada de decisões, execução e avaliação. Em todas essas etapas, o Estado está presente, mediado pelos governos que, por sua vez, mantêm relações nem sempre harmônicas com a sociedade. Por isso, Estado e Governo dão a impressão de se confundirem. Mas o Estado, conforme Pereira (2008, p. 148), "representa mais que um conjunto de instituições com autoridade para tomar decisões e exercer poder coercitivo, pois revela-se também uma relação de dominação". Portanto, o Estado:

[...] é muito mais do que governo, pois, se por um lado, seus sistemas administrativos, legais e coercitivos (policiais) o diferenciam da sociedade e estabelecem formas particulares de relações entre a autoridade estatal e a sociedade civil, por outro lado, esses mesmos sistemas penetram na sociedade e influenciam a formação de relações no interior desta (PEREIRA, 2008, p. 148).

Com base nesse entendimento, percebe-se que a análise das políticas públicas propicia uma visão holística da questão a enfrentar e uma perspectiva de que o todo é mais do que a mera soma das partes constituídas de indivíduos, de instituições, de leis, de ideologias e de interesses particulares, mesmo que existam diferenças sobre a importância 
relativa desses fatores (SOUZA, 2006). Portanto, as políticas sociais públicas destinadas às pessoas idosas precisam ser desenvolvidas organicamente articuladas com as demais políticas socioeconômicas e realizarem-se de maneira descentralizada. Ademais, a sua avaliação deve-se pautar pela seguinte pressuposição assinalada por Boschetti:

[...] a avaliação de uma política social pressupõe inseri-la na totalidade e dinamicidade da realidade. Mais que conhecer e dominar tipos e métodos de avaliação ou diferenciar análise e avaliação, é fundamental reconhecer que as políticas sociais têm um papel imprescindível na consolidação do Estado democrático de direito e que, para exercer essa função, como seu objetivo primeiro, devem ser entendidos e avaliados como um conjunto de programas, projetos e ações que devem universalizar direitos (2010, p. 3).

Reconhecendo o papel imprescindível da política social no atendimento das demandas e necessidades das pessoas idosas e considerando que as leis nacionais e as recomendações da Organização das Nações Unidas - ONU constituem um marco para a regulação desse atendimento por parte do Estado, a pesquisa desenvolvida teve, como fio condutor, as seguintes indagações:

- Nos últimos dez anos, as recomendações da Organização das Nações Unidas (das quais o Brasil é signatário), referentes às pessoas idosas, são aplicáveis à realidade brasileira?

- O Brasil tem procurado seguir essas recomendações?

- Que fatores facilitam ou dificultam o cumprimento dessas recomendações no contexto brasileiro?

- As recomendações da ONU, referentes aos cuidados do idoso e implementadas no Brasil, são compatíveis com as demandas e necessidades das pessoas idosas deste país?

Além desses questionamentos, visando à realização de uma análise da dinâmica do processo de construção das recomendações internacionais e das políticas nacionais na área do idoso, a pesquisa levou em conta as seguintes perguntas que "brotam de necessidades concretas" (ALVES, 2011, p. 64.):

- Como se realizam as discussões no âmbito da Organização das Nações Unidas e no Brasil com vista a contemplar os direitos às pessoas idosas?

- Quais os atores envolvidos nesse processo de discussão?

- Quais os interesses que permeiam esses espaços de discussões?

- Que contribuições o Brasil tem oferecido a essas recomendações internacionais? 
- O Conselho Nacional dos Direitos do Idoso - CNDI tem cumprido o seu papel no controle democrático das políticas sociais referentes aos idosos, especialmente no que diz respeito aos cuidados?

Essas questões expressam o caráter qualitativo da pesquisa e o caminho a ser trilhado em busca de respostas compatíveis com os seguintes objetivos:

\section{OBJETIVOS GERAIS}

Verificar a influência das normativas acordadas em eventos internacionais da Organização das Nações Unidas e da Organização dos Estados Americanos, das quais o Brasil é signatário, na construção do marco legal e das políticas públicas para os idosos, visà-vis o padrão ainda limitado de cidadania prevalecente na realidade brasileira e,

Analisar o conteúdo substantivo das normativas acordadas em eventos internacionais da Organização das Nações Unidas e da Organização dos Estados Americanos comparativamente à concepção e à prática das políticas sociais brasileiras voltadas para os idosos.

\section{OBJETIVOS ESPECÍFICOS}

- Detectar possíveis influências dessas recomendações no contexto da dependência e da política de cuidados às pessoas idosas no Brasil;

- Cotejar políticas relacionadas ao binômio dependência e cuidados, referentes à pessoa idosa, desenvolvidas em países mais envelhecidos e no Brasil.

Fazer pesquisa é, conforme Alves (2011, p. 97), procurar "decifrar códigos", e regularidades na natureza ou na vida social, com vista ao alcance de uma razão, um nexo, ou uma explicação embasada em conhecimento aprofundado de determinadas ocorrências que, à primeira vista, parecem aleatórias. Para produzir essa explicação, o pesquisador parte de hipóteses ou de conjecturas, que são afirmações provisórias e "começo de conversa" com o objeto de estudo para se orientar no percurso investigativo. Por isso, essas afirmações provisórias devem conter em si possíveis respostas, que são utilizadas como recurso heurístico da tarefa de ir afinando essas respostas com indicações fornecidas pela realidade pesquisada.

No caso específico desta pesquisa, e levando-se em conta que o tema do envelhecimento passou a ganhar relevância internacional a ponto de despertar interesse 
pelo estabelecimento de um consenso supranacional, supõe-se que o Brasil, como membro da Organização das Nações Unidas e da Organização dos Estados Americanos e frequente interlocutor das discussões internacionais sobre envelhecimento, tem reconhecido a relevância do tema relativo à proteção dos direitos da pessoa idosa e tem procurado concretizá-lo por meio de políticas públicas. Todavia, fatores estruturais e históricos, associados aos tradicionais limites da cidadania brasileira, têm impedido uma satisfatória aplicação de direitos declarados nas leis. E isso vale para a política de cuidados, que constitui a unidade empírica de análise desta pesquisa.

\section{JUSTIFICATIVA DA PESQUISA E DA ESCOLHA DO TEMA}

A opção por pesquisar a efetividade das normativas internacionais e de seu poder de influência sobre as políticas brasileiras de defesa dos direitos da pessoa idosa, particularmente a política de cuidados, deve-se, primeiramente, à relevância social e política do acelerado processo de envelhecimento populacional em escala planetária, cuja compreensão exige investigação científica e tratamento analítico contínuos e sistemáticos. E, em segundo lugar, deve-se ao interesse profissional e político desta pesquisadora, de aferir se, no Brasil, esse processo tem, de fato, implicado mudança na pauta de reivindicações sociais e suscitado a implementação de políticas públicas correspondentes.

A autora desta tese, por participar e acompanhar, há vários anos, as discussões sobre o tema aqui contemplado, sentiu-se motivada a refletir metodicamente sobre ele para realizar não apenas uma análise que se restringisse à letra das normas, mas, sobretudo, incluísse as efetivas ações do sujeitos e das organizações promotoras de políticas sociais públicas.

A importância deste estudo torna-se evidente pelo fato de o envelhecimento populacional ser uma realidade mundial que já vem afetando drasticamente as políticas públicas em geral. De acordo com a Organização das Nações Unidas - ONU, há previsão de que, entre os anos 2000 e 2050, a proporção de pessoas com 60 anos e mais de idade duplicará, passando de $10 \%$ para $21 \%$, enquanto o percentual de crianças reduzir-se-á de $30 \%$ para $21 \%$. Nos países em desenvolvimento, esse processo será mais acentuado: em 2050, a proporção de idosos aumentará de $8 \%$ para $19 \%$, enquanto a de crianças decrescerá de 33\% para 22\%. Em 2025, 82\% das pessoas idosas dos países em desenvolvimento viverão em áreas urbanas. O Brasil, segundo projeções demográficas, será, nesse ano, o sexto país do mundo em população idosa, com 32 milhões de pessoas com 60 anos e mais de idade; e até já se comenta que seria o quinto. Hoje, de acordo com a 
PNAD 2012, essas pessoas já são em torno de 24,2 milhões, o que equivale a $12,6 \%$ da população total.

Em suma, a importância de estudos que tratam as questões relacionadas ao fenômeno do envelhecimento populacional pode ser percebida na emergência do tema nas agendas públicas internacional e nacional.

\section{METODOLOGIA}

Traçar o panorama das políticas públicas voltadas para os idosos no Brasil; a influência das normativas internacionais; a forma como se coloca no ordenamento jurídico brasileiro; que tipo de proteção institucionalizada foi instituída para assegurar os direitos da pessoa idosa; como já indicado, esse é o escopo desta pesquisa. Neste, deu-se ênfase investigativa ao como vêm sendo consideradas e desenvolvidas as ações previstas nas legislações de defesa de direitos da pessoa idosa vis-à-vis normativas internacionais congêneres, no contexto capitalista recente.

Para tanto, utilizou-se um método que, conforme Lenin (1955, apud MINAYO, 2010, p. 44), não fosse exterior ao objeto de estudo, mas constituísse "a própria alma do conteúdo porque ele faz a relação entre pensamento e existência e vice-versa".

A pesquisa realizada caracterizou-se como um processo de conhecimento que buscou relacionar estrutura e história, isto é, que procurou considerar tanto as determinações de fundo econômico e demográfico, que se movimentam de forma quase autonomizada de acordo com suas leis de funcionamento, quanto as ações intencionais dos sujeitos historicamente afetados por essas determinações. Trata-se do que se convencionou chamar de "método histórico-estrutural"; um método que visa empreender um esforço de conhecimento totalizante do objeto em suas tendências gerais e particulares.

Segundo Minayo:

As sociedades humanas existem num determinado espaço cuja formação social e configurações culturais são específicas. Elas vivem o presente marcado pelo passado e projetado para o futuro que em si traz, dialeticamente, as marcas pregressas numa reconstrução constante do que está dado e do novo que surge (MINAYO, 2010, p. 39).

Nesse sentido, a pesquisa pautou-se por um percurso investigativo que se tornou dialético, histórico e relacional por obedecer à dialética da realidade pesquisada que, ontologicamente, é eivada de sinuosidades e de contradições. Foi por essa perspectiva que se procurou articular as normativas - internacionais e nacionais - com a dinâmica concreta 
da vida brasileira, cujas políticas sociais possuem um histórico de desenvolvimento periférico e de conquistas tardias de direitos sociais.

As principais fontes de dados e informação compulsadas foram secundárias, de caráter documental. Contudo, também foram utilizadas as fontes primárias representadas por pessoas e instituições-chave, tanto no Brasil quanto na Espanha, onde, durante quatro meses, a autora desta tese realizou estágio de doutoramento-sanduíche, patrocinado pela Coordenação de Aperfeiçoamento de Pessoal Docente - CAPES, do Ministério de Educação - MEC. Foi por meio das fontes documentais que se conheceu e se procedeu, qualitativamente, a análise do conteúdo das normativas internacionais, das leis e políticas nacionais, assim como das implicações sociais e políticas do intento governamental de aplicação desse conteúdo no Brasil. Porém, dessa fonte também foram extraídos e considerados dados quantitativos de particular contribuição para o esclarecimento do objeto de estudo e para a confirmação da hipótese de trabalho formulada. Tanto as informações e dados qualitativos quanto quantitativos foram obtidos nas fontes a seguir indicadas.

Espanha: Universidade de Alcalá de Henares - Faculdade de Economia, sob a orientação do Professor Dr. Gregório Rodriguez Cabrero; Instituto de Mayores y Servicio Social del Ministério de Salud (órgão coordenador da Política do Idoso na Espanha); Fundación Pilares para la Autonomia; Centro Dia e Residência Instituição Sant AntoniL’Onada (pública com gestão privada) - Barcelona; Centro Dia e Residência PortaFundação Vella Terra (público, com gestão privada) - Barcelona; Centro Dia e Residência Masbau y Los Joseps - Fundação Privada Sant Antoni Abat (privado mas com vagas compradas pelo governo - "plazas concertadas") - Villanova; Centro Dia e Residência Santa Engrácia (pública com gestão privada - EULEN) - Madri; Centro Dia ASISPA - Asistencia a Personas Mayores (pública com gestão privada) - Madri; Servicio de Atención Domiciliar SAD - ASISPA (público com gestão privada) - Madri; Serviço de Teleassistência - ASISPA - Madri; Centro Dia São José de Villareal, para idosos com demência e deficiência física (público com gestão privada - La Casona) - Madri; Centro Dia Atalaia - Consórcio Gallego (público com gestão pública) - Vigo; Centro Dia Beiramar - Associação de Familiares com Alzhaimer da Galícia - AFAGA para idosos com demência (público com gestão privada) Vigo; Centro Dia Parque Castrelos (privado com algumas vagas públicas) - Vigo; Unión Democrática de Pensionados y Jubilados - UDP - Madri, Organização Iberoamericana de Seguridade Social - OISS - Madri.

E, ainda, foram realizadas as entrevistas com os seguintes especialistas em Política Social e Envelhecimento: Antoni Vilá - Professor Pesquisador em Política Social da Universidade Autônoma de Barcelona; Eulalia Cucurella - Presidente da Fundação Alzheimer da Catalunha e trabalhadora social responsável pelos centros próprios com 
gestão própria e gestão privada do Departamento de Bem-Estar Social e Família da Generalitat da Catalunya - Barcelona, além de controlar o cumprimento das normas técnicas das instituições próprias e privadas; Pilar Rodriguez - Presidente da Fundação Pilares para la Autonomia Personal - Madri; Demetrio Casado - Especialista em Política Social, Educativa e Sanitária, funcionário público aposentado do Ministério do Trabalho e diretor técnico do Real Patronato sobre Discapacidad - Madri; Juan de la Torre Vidal - chef del Departamento de Centros de Dia y Residenciales e Director General de Mayores y Atención Social de Ayuntamiento de Madri; Miguel Ángel Vazquez Vazquez - professor pesquisador da Universidade de Vigo.

No Brasil: foi feita a aplicação de questionário junto aos Conselhos Estaduais e Municipais de Defesa de Direitos da Pessoa Idosa. Os municipais escolhidos foram os das capitais; porém, como apenas $40 \%$ das capitais responderam o questionário, foram selecionados aleatoriamente mais dois municípios (Santos - SP e Feira de Santana - BA), por serem um dos maiores em seus Estados (São Paulo e Bahia, respectivamente). Os Conselhos Estaduais que responderam o questionário foram: Acre, Amapá, Amazonas, Distrito Federal, Rondônia, Goiás, Maranhão, Pernambuco, Paraná, Minas Gerais, Rio de Janeiro e Santa Catarina; e os municipais: Belo Horizonte, Cuiabá, Maceió, Palmas, São Paulo, Santos, Recife, São Luís, Feira de Santana e Florianópolis.

Foi ainda formulada uma questão-chave para ser respondida por cinco pessoas idosas que protagonizaram o processo de construção e de implementação da Política do Idoso, sendo uma de cada região. Dentre elas, quatro com mais de 70 anos de idade.

Dos órgãos que atuam na Política do Idoso no plano federal, foram selecionados os que compõem o Sistema de Seguridade Social, constituído das políticas de previdência, saúde e assistência social, sendo entrevistados um coordenador-geral e uma gestora pública. Infelizmente, em que pesem vários contatos efetuados junto à Secretaria Nacional de Assistência Social, com finalidade de entrevistar um especialista da área, não se obteve resposta.

A prioridade dada à escolha da análise qualitativa deve-se ao fato de, nesta pesquisa, ter sido privilegiada a palavra expressa, especialmente a escrita, como um dado objetivo, o que encontra respaldo no seguinte pensamento de Minayo: "o material primordial da investigação qualitativa é a palavra que expressa a fala cotidiana, seja nas relações afetivas e técnicas, seja nos discursos intelectuais, burocráticos e políticos" (MINAYO, 1993, p. 245); e mais: 
inerente e que quantidade e qualidade são inseparáveis e interdependentes (MINAYO, 2010, p. 25).

\section{PROCEDIMENTOS METODOLÓGICOS}

A pesquisa adotou os seguintes procedimentos metodológicos:

- Seleção e análise dos documentos dos Organismos internacionais, como: Organização das Nações Unidas, Organização dos Estados Americanos e Comissão Econômica para América Latina e Caribe - CEPAL, que abordam os direitos das pessoas idosas, assim como os do que, no Brasil, foram criados com vista a contemplar a aplicabilidade dos acordos de defesa de direitos da pessoa idosa firmados pelo país;

- Seleção e análise de documentos nacionais, como a Política Nacional do Idoso e o Estatuto do Idoso, além de deliberações das três Conferências dos Direitos da Pessoa Idosa e de informações sobre a sua aplicabilidade;

- Identificação dos movimentos sociais de defesa dos direitos das pessoas idosas e análise de seus principais feitos e conquistas;

- Coleta direta de dados e de informações referentes ao controle democrático da Política Nacional do Idoso junto aos Conselhos Estaduais e Municipais de Defesa dos Direitos da Pessoa Idosa;

- Visitas, na Espanha, a Centros Dia, Instituições de Longa Permanência para idosos, para observar e colher informações sobre cuidados dos idosos, atendimento domiciliar e teleassistência;

- Entrevistas realizadas com especialistas, na Espanha, para tratar da aplicabilidade da Lei da Dependência;

- Levantamento de referências bibliográficas sobre dependência e cuidados;

- Realização, no Brasil das seguintes atividades: consultas às legislações existentes sobre a atenção aos cuidados dos idosos, levantamento nos municípios sobre programas de atenção à pessoa idosa dependente e pesquisa de referências bibliográficas sobre o tema;

- Aplicação do questionário junto aos Conselhos Estaduais e Municipais do Idoso.

Dentre os documentos consultados, destacam:

- Conclusões dos grupos de composição aberta da Organização das Nações Unidas e da Organização dos Estados Americanos sobre os direitos da pessoa idosa; 
- Resultados da 1a reunião de seguimento da Declaração de Brasília e da Carta de São José;

- Sistema de Informação Social do IBGE;

- Anais das Conferências Nacionais de Defesa dos Direitos da Pessoa Idosa;

- Documentos das reuniões da sociedade civil de seguimento do Plano de Ação Internacional para o Envelhecimento.

$E$, junto às fontes diretas, adotaram-se os seguintes procedimentos, técnicas e instrumentos:

No Brasil:

Além da aplicação de questionários junto aos Conselhos Estaduais e Municipais já indicados, procederam-se:

- Identificação dos sujeitos que participaram do processo de construção e implementação da Política do Idoso, para entrevistá-los e conhecer de que maneira vem sendo implementada a referida política;

- Realização de entrevista, por email, com o coordenador da Política de Saúde do Idoso do Município de São Paulo e com a Presidente do Conselho Municipal do Idoso de Belo Horizonte para identificar as ações realizadas em benefício das pessoas idosas que necessitam de cuidados.

Na Espanha:

- Aplicação de questionário a especialistas em política social que realizam investigações e dão atenção às pessoas idosas dependentes que necessitam de cuidados;

- Entrevista com servidor que atua no órgão coordenador da Política para idosos;

- Participação em seminário e jornada sobre idoso e dependência.

$\mathrm{Na}$ Organização das Nações Unidas, a autora desta tese participou de quatro sessões do GT de composição aberta sobre os direitos da pessoa idosa, em Nova York.

De posse dos dados coletados, foram possíveis:

- Reflexões críticas a respeito da influência das normativas internacionais sobre a legislação brasileira de defesa dos direitos da pessoa idosa; 
- Análises da participação e dos posicionamentos governamentais nas discussões internacionais sobre o seguimento do Plano de Madri e do grupo de composição aberta, no âmbito da Organização das Nações Unidas e da Organização dos Estados Americanos - OEA, para a construção de um documento de âmbito internacional, juridicamente vinculante, de direitos humanos das pessoas idosas.

Enfim, todas as informações colhidas foram analisadas com o objetivo de verificar a pertinência, ou não, da hipótese de trabalho formulada como um recurso heurístico indispensável ao conhecimento do objeto que constitui o núcleo essencial da pesquisa.

A tese está dividida em cinco capítulos, além dos itens introdutório e conclusivo. O primeiro capítulo tem caráter e função conceitual e, portanto, instrumental. Apresenta a concepção de envelhecimento e de conceitos que lhe são correlatos, sob a forma de explicitação das categorias centrais de análise. Trata, por conseguinte, de qualificar, com anterioridade, o significado de Estado e Sociedade e de suas relações, particularizando o Estado moderno, capitalista - com seu aparato institucional, legal e político - e a sociedade como espaço das classes sociais. Qualifica, também, noções de "cuidado" e "dependência", no âmbito do envelhecimento; de "política social" como resultado da relação conflituosa entre Estado x sociedade e governo $x$ cidadãos, tendo como pano de fundo o antagonismo entre capital e trabalho; de direitos de cidadania, com ênfase no direito social; e de movimentos sociais organizados em torno da defesa de direitos da pessoa idosa.

O segundo capítulo aborda o capitalismo contemporâneo em crise e as possibilidades de realização das políticas públicas para o envelhecimento nessa conjuntura, dando destaque à dependência e ao cuidado. Contudo, para melhor retratar as limitações atuais do chamado Estado de Bem-Estar capitalista, que gerencia tais políticas, teve-se que fazer remissão às suas diferentes fases, incluindo o período de ouro dos anos 1940 a 1970, para confrontá-lo com o "período de bronze" (passando pelo de "prata") dos dias correntes, iniciado nos anos 1980. E, neste último período, o sistema socioassistencial referente à pessoa idosa dependente de cuidados recebeu atenção particular.

O capítulo terceiro traça o panorama histórico das medidas formais de defesa de direitos do idoso no âmbito internacional e indica os principais eventos promovidos pela Organização das Nações Unidas e pela Organização dos Estados Americanos para criação coletiva e supranacional dessas medidas. Apresenta, igualmente, as normativas aprovadas por esses organismos, os mecanismos de seguimento dessa normatização e as suas possíveis influências, as quais merecem análise mais particularizada no Brasil. Eis por que o capítulo quarto aborda a evolução e o perfil da legislação e da política do idoso brasileiro, no 
rastro das normativas internacionais, assim como o processo de conquistas dos direitos do idoso no país.

Por fim, o capítulo quinto trata dos serviços de atenção às pessoas idosas dependentes, identificando-os tanto no contexto espanhol, no qual a autora da tese realizou estudos complementares sobre essa temática, quanto no Brasil. No que diz respeito à Espanha, são indicadas as legislações criadas para dar cobertura aos serviços destinados às pessoas idosas; as mudanças ocorridas em função da crise capitalista em curso; o funcionamento das instituições visitadas e as propostas de cobertura do seguro cuidado. E no Brasil, indicam-se as legislações existentes, as dificuldades para implementação das ações em prol das pessoas idosas dependentes e o cenário das ILPIs e dos demais serviços. E, ainda, consta um anexo que contempla as visitas realizadas na Espanha. 


\section{ENVELHECIMENTO E CONCEITOS CORRELATOS REVISANDO A LITERATURA ESPECIALIZADA}

Ler o real social, questioná-lo e conhecê-lo: precisa-se de palavras
para isso. Como nomear aquilo do que se trata, distinguir uma
realidade de outra, falar dela com outros havendo mútua
compreensão? Com esse fim, dentre as palavras, desenvolveram-
se as que chamamos conceitos.

Laville \& Dione

PREÃMBULO

Este capítulo é de natureza e escopo conceitual. Explicita as categorias analíticaschaves da pesquisa e, com base nelas, procede-se a revisão do referencial teórico no qual esta tese se baseia. Trata-se de categorias que estão no cerne da discussão teórica e política sobre a estrutura de poder do Estado nas suas relações de antagonismo e de reciprocidade com a sociedade, o processo dialético de correlação de forças entre interesses conflitantes e a luta por direitos e cuidados na esfera do envelhecimento.

Dentre as categorias a seguir explicitadas, que, direta ou indiretamente, marcarão presença nos capítulos substantivos desta tese, destacam-se: Estado e sociedade, política social, direitos, movimento social associado à luta por proteção aos idosos, envelhecimento populacional, dependência e cuidado na velhice.

\subsection{ESTADO, SOCIEDADE E POLÍTICA SOCIAL}

O Estado aqui abordado é o moderno, capitalista, aquele que atua na produção, na distribuição e no controle das políticas públicas e é ontologicamente dependente da sociedade. Essa relação com a sociedade é fundamental para compreensão de sua origem e significado. Conforme Pereira, "ambas as entidades [Estado e sociedade] têm particularidades e interesses próprios, embora interdependentes e, portanto, [não possuem] autonomia absoluta" (PEREIRA, 2008, p. 135).

Foi no século XVII que o Estado tornou-se instituição verdadeiramente política, com ascendência sobre as demais instituições e adquiriu persona própria, separada dos governantes e das influências religiosas. Nesse contexto, rompeu com a religião, o que o levou a ter poder particular e a organizar sua estrutura técnico-administrativa. Para isso, contribuíram iniciativas de demarcação de suas fronteiras territoriais, cobrança de impostos, formação de fundo público, criação e manutenção de forças armadas que thes conferiram a prerrogativa de ser a única instituição dotada de poder coercitivo. Eis por que, para Weber 
(1973 apud PEREIRA, 2008, p. 136) “o Estado é o monopólio legal da violência, como um atributo característico das autoridades legítimas, impeditivo da multiplicação de iniciativas privadas e de autodefesa armada ou da instauração de regimes de exceção". Disso inferese que o poder do Estado não Ihe é inerente ou natural, mas, sim, adquirido e consentido pela sociedade.

No entanto, com o passar do tempo, a complexificação da sociedade ao do seu poder coercitivo, o Estado passou a desenvolver outra forma de dominação não violenta, mas nem por isso menos importante. É o que Gramsci (apud PEREIRA, 2008, p. 136) chama de hegemonia, indicando, com essa categorização, que, "para além do uso da coerção, há outras ações do Estado que não requerem força nem mesmo como ameaça". É, portanto, no campo da hegemonia que as políticas públicas se situam e se processam; e é por meio dessa modalidade não coercitiva de dominação que o Estado atual adquiriu várias e diferentes atribuições, as quais perpassam desde a vigilância de suas fronteiras até a preservação da ordem nacional.

Para Mascaro (2013, p.18) "o Estado [com essas características] é um fenômeno especificamente capitalista. Sobre as razões dessa especificidade, que separa política de economia, não se pode buscar respostas, a princípio, na política, mas sim no capitalismo", porque "o Estado é um derivado necessário da própria reprodução capitalista" (MASCARO, 2013, p. 19). Por outro lado, o capitalismo não sobreviveria sem o apoio do Estado, porque é este que cria as condições para o seu desenvolvimento e o socorre nos momentos de crise.

Disso decorre o fato de o Estado não ser neutro e de seu vínculo com o capitalismo não ser acidental. Entretanto, apesar de ter caráter de classe, como afirma Poulantzas (1981), e ser identificado como uma organização burguesa, ele não pode deixar de conhecer e, em certa medida, atender os pleitos das classes dominadas. É isso que the garante a indispensável legitimidade e dá-Ihe a aparência de universalidade e da posição de estar acima das classes sociais. Mas, também, é esse modo de proceder que desnuda o seu caráter dialeticamente contraditório, isto é, de ser ao mesmo tempo interlocutor e provedor de demandas do capital e do trabalho. Assim, a melhor definição do Estado de tipo capitalista, encampada por este estudo, é aquela que, nos termos de Jessop (2008), com base em Poulantzas, identifica-o como uma:

[...] relación social. Esto implica que el ejercicio del poder estatal (o, mejor aún, de los poderes del Estado en plural), supone una condensación determinada por la forma del cambiante equilibrio de fuerzas. En otras palabras, el poder del Estado refleja el equilibrio de fuerzas predominante, mediado por el poder estatal en su selectividad estratégica inscrita estructuralmente. Al adoptar-se este enfoque, el Estado pode definir-se como un conjunto relativamente unificado de instituciones, organizaciones, fuerzas sociales y actividades socialmente incrustadas, socialmente reguladas y 
selectivas estratégicamente, que se organiza en torno de la toma de decisiones (o que al menos se involucra en ella) que son vinculantes colectivamente para una comunidad política imaginada (p. 46).

Em suma, esse enfoque desaconselha tratar o Estado seja como um sujeito dotado de poder imanente e refratário a ingerências ou pressões da sociedade, seja como um simples instrumento a serviço exclusivo de uma determinada classe, apesar - como já salientado - de ele ter caráter de classe. É essa particularidade que lhe permite incorporar demandas por direitos emanadas por diferentes classes e segmentos sociais, entre as quais as referentes às pessoas idosas.

Contudo, por ser capitalista mesmo garantindo direitos sociais, ele mantém a lógica do valor: tem que saber quanto vai gastar na provisão de políticas que concretizem esses direitos; e até mesmo os aumentos concedidos aos trabalhadores têm relação com a referida lógica. Como afirma Mascaro:

[...] uma sociedade capitalista, a identidade de tudo com tudo é mercantil, e poder-se-ia dizer então, no limite, que a própria noção lógica e mental de identidade remonta a alguma espécie de intercâmbio de objetos e pessoas como mercadorias. A própria operação de reciprocidade de objetos distintos se faz, ou se completa, como pensamento, a partir da constituição de relações sociais como a do dinheiro (MASCARO, 2013, p. 22).

Porém, quem garante a reprodução social é o Estado. Sendo assim, a sociabilidade do capitalismo só é possível com a contribuição do Estado, já que "as formas sociais capitalistas ensejam a estruturação da própria reprodução social" (MASCARO, 2013, p. 24). Assim, se as relações sociais capitalistas constituem formas sociais como a forma-valor, a forma-mercadoria, a forma-sujeito de direito decorre do entrelaçamento do Estado com essas relações (MASCARO, 2013, p. 27).

O Estado, com todo o seu aparato institucional, está sempre atrelado aos meios que buscam condições políticas para o desenvolvimento do capital. Quando há crises estruturais no capitalismo, o Estado tem todas as condições de intervir para a reorganização e a melhora dessa situação; ou pode, também, levá-la ao colapso.

O Estado, dado o seu caráter contraditório, também utiliza meios para cercear a sociedade quando lhe é conveniente, atingindo grupos ou classes sociais. E aí ele exerce a sua seletividade estratégica de que fala Jessop, como, por exemplo, no âmbito dos direitos das pessoas idosas.

Note-se o embate nas negociações que vêm sendo feitas, no Brasil, pelo grupo dos aposentados e pensionistas, representados por sindicatos e associações. Estes reivindicam melhores reajustes nas aposentadorias e pensões, como a queda do fator previdenciário, e, ainda, a criação de uma secretaria dos idosos, aposentados e pensionistas na estrutura do Poder Executivo da Administração Pública Federal para que, por seu intermédio, as políticas 
públicas de defesa de direitos das pessoas idosas sejam efetivadas. Porém, durante todo o ano de 2013, aconteceram reuniões mensais do Conselho de Previdência Social e do Grupo de Trabalho dos aposentados e pensionistas, coordenado pelo Ministério da Previdência Social, com apoio da Casa Civil da Presidência da República, sem que nada de concreto tenha sido negociado.

Nesse caso, observa-se claramente, que, no executivo estatal, os gestores optam pelos interesses econômicos priorizando as grandes empresas, enquanto as demandas dos grupos sociais, com pouca influência, são negligenciadas. Nesse contexto, a ação dos movimentos sociais é indispensável para garantir maior justiça na distribuição dos bens sociais públicos, pois, sem pressão social, a conquista é dificultada, porque gera desequilíbrio na correlação de forças. É como assinala Mascaro:

As lutas das classes não avançam como tais nas teias dos Estados, ficando
retidas nas categorias da forma política-cidadão, voto e representação e da
forma jurídica-cumprimento dos direitos subjetivos e deveres dos sujeitos de
direito, pessoa física e pessoa jurídica. [Mas, é preciso ter em mente que] A
forma política estatal, sendo autônoma em relação aos indivíduos, grupos e
classes, assim o é apenas relativamente, porque espelha, estrutural e
necessariamente, a própria reprodução capitalista. Não é pelas classes que o
dominam, mas pela forma, que o Estado é capitalista (MASCARO, 2013, p.
50).

Contemporaneamente, o Estado mantém formas de relações mais ampliadas com a sociedade civil, nas quais, de acordo com Gramsci, "não prevalece a força, mas direção espiritual e cultural, voltada para todo o complexo das relações ideológico-culturais-escolas, religião, comunicação - por meio do qual as classes exercem a sua hegemonia de forma consensual" (GRAMSCI apud PEREIRA, 2008, p.158).

Essa correlação de forças é constante entre a sociedade civil - constituída de agrupamentos sociais, como partidos políticos, sindicatos, associações, igrejas, dentre outros - e o Estado, o qual, em última instância, detém o poder coercitivo. E, nesse confronto, a vontade do Estado hegemônico tende, no fundo, a prevalecer.

A sociedade, considerada por lanni (1986) como o espaço das classes sociais, não deve ser considerada como uma simples soma de indivíduos. Contemplando os fundamentos do Estado, sua natureza não poderia ser diferente daquele. Portanto, a sociedade também deve ser entendida como um conjunto de relações que são históricas e que igualmente expressam antagonismos e reciprocidades simultâneos, típicos de sociedades de classes. Para abordar a sua organização e forma burguesa, é necessário visitar tanto sua história, bem como os seus determinantes econômicos, sociais, políticos e culturais. 
No modo de produção capitalista, duas classes se destacam: os trabalhadores e a burguesia. Marx foi o grande estudioso da sociedade burguesa e de acordo com Neto (2012), seu estudo visavam conhecer sua estrutura e dinâmica. Para Marx, portanto, "a sociedade é o produto da ação recíproca dos homens" que:

[...] a um determinado estágio de desenvolvimento das faculdades produtivas corresponde determinada forma de comércio e de consumo. As determinadas fases do desenvolvimento da produção do comércio e do consumo correspondem determinadas formas de constituição social, determinada organização da família, das ordens ou das classes; uma palavra, uma determinada sociedade civil. A uma determinada sociedade civil corresponde um determinado estado político, que não é mais que a expressão oficial da sociedade civil (apud NETO, Id., p. 9).

Com o desenvolvimento das forças produtivas e das relações de produção, os homens também mudaram a forma de se relacionar, a maneira de produzir e, consequentemente, o processo de trabalho e modo de vida. A sociedade dividida em classes passou a experimentar um constante e conflituoso movimento em torno da apropriação privada do produto coletivo do trabalho humano. No capitalismo moderno e contemporâneo, a correlação de forças entre Estado e sociedade contempla também a luta por direitos, incluindo os sociais conquistados pelos movimentos trabalhistas e sociais em geral.

De acordo com Pereira (2008), uma contribuição teórica importante para a compreensão de sociedade no capitalismo é a de Gramsci, a qual, centrando-se no conceito mais delimitado de "sociedade civil", conseguiu explicar a particularidade da relação de mútua influência entre Estado e sociedade na contemporaneidade. A originalidade do pensamento de Gramsci, diz a autora:

[...] está na ampliação marxista do conceito de Estado (Estado ampliado), no qual inclui a sociedade. Isso difere da concepção restrita de Estado, de Marx, para quem o Estado é um instrumento de dominação da classe dominante e a sociedade civil faz parte do terreno estrutural ou da "base material" (PEREIRA, 2008, p. 159).

Assim, distinguindo sociedade civil e sociedade política (Estado restrito), Gramsci define a primeira como:

[...] o conjunto das instituições responsáveis pela representação dos interesses de diferentes grupos sociais, bem como pela elaboração e/ou difusão de valores simbólicos, de ideologias, compreendendo o sistema escolar, os partidos políticos, as igrejas, as organizações profissionais, os sindicatos, os meios de comunicação, as instituições de caráter científico e artístico (COUTINHO, 1996, p. 54 apud PEREIRA, 2008, p. 159).

E a sociedade política como:

[...] o conjunto de aparelhos por meio dos quais a classe dominante detém ou exerce o monopólio legal ou de fato da violência; trata-se, portanto, dos aparelhos coercitivos do Estado, encarnados nos grupos burocráticoexecutivos ligados às forças armadas e policiais e à aplicação das leis (COUTINHO, 1996, p. 54, apud PEREIRA, 2008, p. 159). 
Logo, a junção da sociedade política (Estado restrito) com a sociedade civil forma o Estado ampliado, o qual exerce, ao mesmo tempo, hegemonia (atributo da sociedade civil) e coerção (atributo da sociedade política).

É pela perspectiva do Estado ampliado que esta tese se orienta, uma vez que ela permite a identificação dos movimentos sociais e especialmente a dos Conselhos de Defesa dos Direitos do Idoso como um canal de participação de instituições da sociedade civil para exercerem o controle democrático.

A sociedade civil, para conquistar seus direitos, necessita organizar-se para pressionar o Estado. No caso da população idosa, no Brasil, as legislações existentes, destinadas a garantir os direitos desse segmento, definem importantes avanços no campo da cidadania, visto preverem ações intersetoriais e descentralizadas a serem desenvolvidas por intermédio dos entes federados - Estados membros, Distrito Federal e municípios. No entanto, após mais de 10 anos da promulgação dessas legislações, constata-se que elas pouco avançaram na sua implementação.

Os direitos sociais devem ser concretizados por política social. O processo de implementação das ações dessa política está associado a um contexto que diz respeito à forma de organização e à produção social da sociedade que a contempla. Assim, com a finalidade de compreender como ocorre a legitimação dos direitos sociais da pessoa idosa, é necessário refletir sobre política social.

Na perspectiva deste estudo, política social refere-se:

[...] a ações que determinam o padrão de proteção social implementado pelo Estado, voltadas, em princípio, para redistribuição dos benefícios sociais visando à diminuição das desigualdades estruturais produzidas pelo desenvolvimento socioeconômico. As políticas sociais têm suas raízes nos movimentos populares do século XIX, voltadas aos conflitos surgidos entre capital e trabalho, no desenvolvimento das primeiras revoluções industriais (HOFLING, 2001, p. 31).

Política social é também uma disciplina acadêmica e interdisciplinar (ALCOCK, 1992). Configura-se como um fato complexo que se insere nas funções sociais do Estado e na mobilização política da sociedade. Esse é o motivo pelo qual, também para Dean (2006), a política social refere-se a muitas coisas com as quais os governos gastam os recursos arrecadados da sociedade. Nada mais natural, portanto, que esta espere ou exija retornos políticos dos governos.

Pode-se dizer, conforme Pereira:

[...] que a política social só ganhou densidade institucional e dimensão cívica quando se consolidou o Welfare State, que começou a ser formado na Europa, no último terço do século XIX, e se firmou em meados do século XX como o modelo estatal diretamente responsável pelo atendimento de 
necessidades sociais agravadas pelo inexorável desenvolvimento capitalista.

Sinteticamente, tal fato foi impulsionado por dois principais conjuntos de forças em expansão, desde a segunda metade do século XVIII, a saber:

- A Revolução Industrial, com sua capacidade sem precedentes de reproduzir bens materiais e de poder livrar as classes laborais da pobreza herdada do processo de construção dos Estados nacionais, na Europa Ocidental, desde o fim da Idade Média;

- As mobilizações sociais pela conquista de direitos individuais - civis e políticos - sob o efeito das revoluções burguesas (em particular da francesa, de 1789), que transformaram a antiga ordem feudal na ordem capitalista dominada pela produção mercantil e pela ideologia liberal (PEREIRA, 2008, p. 59).

Dessa feita, a política social se expressa, preponderantemente, como:

[...] política de ação que visa, mediante esforço organizado e pactuado, atender necessidades sociais cuja resolução ultrapassa a iniciativa privada, individual e espontânea, e requer deliberada decisão coletiva regida por princípios de justiça social que, por sua vez, devem ser amparados por leis impessoais e objetivas, garantidoras de direitos (PEREIRA, 2008, p. 171).

$\mathrm{E}$, como tal, a política social se configura como uma política pública, isto é, comprometida com todos que, em tese, possui caráter universal. Entretanto, convém indagar: de onde vem e o que significa o termo "política pública"?

Para Souza (2006, p. 22), a política pública enquanto área de conhecimento e disciplina acadêmica nasceu nos Estados Unidos, em 1948. Na Europa, essa modalidade de política surgiu também no segundo pós-guerra como um dos desdobramentos de uma das mais importantes instituições do Estado: o governo. Entretanto, Pereira (2008) esclarece que:

[...] política pública não é sinônimo de política estatal. A palavra pública, que sucede a palavra política, não tem identificação exclusiva com o Estado. Sua maior identificação é com o que em latim se denomina de res publica, isto é res (coisa), pública (de todos), e, por isso, constitui algo que compromete tanto o Estado quanto a sociedade. É, em outras palavras, ação pública, na qual, além do Estado, a sociedade se faz presente, ganhando representatividade, poder de decisão e condições de exercer o controle sobre a sua própria reprodução e sobre os atos de decisão do governo (PEREIRA, 2008, p.94).

Fica evidente, com base nessa argumentação, que a política pública resulta da relação entre Estado e sociedade e entre governo e cidadão. Como toda e qualquer política, é de natureza conflituosa, porque configura uma representação de interesses divergentes. Vale dizer: a política pública é produto do confronto de sujeitos sociais que diferem não só quanto à raça, à idade, ao sexo, mas também quanto à etnia e às ideologias, além da classe social. Logo, é de se esperar que tal política contenha em si uma heterogeneidade de demandas, o que a induz a ser contraditória, isto é, a ser levada a procurar satisfazer, simultaneamente, diferentes interesses, sendo que será mais bem atendido quem tiver maior força ou poder. Essa é uma característica fundamental da política social considerada neste estudo. 
No tocante às modificações sofridas pela política social no curso da História, vale ressaltar que, a partir do final dos anos 70 do século XX, ela, de acordo com Pereira:

[...] trouxe à luz as mudanças internas e externas ao Estado de Bem-Estar, causadas, respectivamente, pela passagem de um modelo de produção fordista para um outro, pós-fordista, e pelo processo de globalização. Disso resultou uma nova fase de reformas sociais eivada de desafios e de conflitos inevitáveis. A presença de situações dilemáticas decorrentes do envelhecimento populacional, do desemprego estrutural, da reestruturação da família, da dinâmica migratória, transcenderam as dimensões econômicas e fiscais e requereram no bojo da política social, novas correlações de forças (PEREIRA, 2008, p.192).

Em relação ao envelhecimento populacional, a implementação de políticas sociais públicas destinadas às pessoas idosas apresenta retrocessos no tocante a serviços, aposentadorias e pensões, uma vez que não constituem prioridade do modelo neoliberal dominante em âmbito planetário. Por ser uma demanda que não interessa ao mercado, apesar de ser socialmente legítima, os recursos públicos a ela destinados são sempre escassos Além disso, o atendimento dessa demanda sofre um processo de privatização, haja vista que parte das ações implementadas são desenvolvidas por entidades privadas sem fins lucrativos. Isso explica o porquê, também nessa área, da tendência de prevalecerem políticas sociais compensatórias, focalizadas na extrema pobreza. Tais políticas, ao deixarem de atender cidadãos que não estão na miséria, rompem com o princípio da isonomia ou da universalidade, ao mesmo tempo em que aumenta a pobreza relativa. Essa tendência tende a se acentuar com a elevação do número dos mais idosos, pois é nesse grupo que se concentra o maior número de pessoas com dependência para a realização de atividades de vida diária - AVDs.

Tal situação está associada ao fato de que, para o capitalismo, especialmente em sua atual fase neoliberal, os idosos são considerados improdutivos e um peso para a seguridade social. Por isso, são incluídos no rol dos responsáveis pela crise do sistema. Ou, no dizer de Boschetti (2010, p. 69):

[...] os "responsáveis" por essa nova crise foram a ampliação dos direitos sociais, das políticas sociais, dos direitos relacionados ao trabalho, conquistados pela classe trabalhadora no período usualmente conhecido como "30 anos gloriosos", ou "anos de ouro do capitalismo" ( sic).

Essa afirmação da autora foi aqui utilizada para explicitar que, se os anos foram de ouro quanto aos direitos e às políticas sociais asseguradas, a crise foi consequência das contradições do próprio sistema capitalista, o qual não existe sem elas e delas se alimenta para ampliar sua capacidade de acumulação. E, nesse contexto, os direitos sociais dos trabalhadores, dos aposentados e dos pensionistas, tão necessários à equidade intergeracional e ao bem-estar na velhice, estarão sempre inseridos nesse campo de contradições e de correlação de forças capitalistas. 
A concretização dos direitos sociais se faz com políticas sociais públicas. Isso é uma questão muito mais profunda do que a mera declaração de direitos faz crer. A sua complexidade assim o demonstra. É como diz Bobbio (2004), o grande desafio de nosso tempo é a efetivação de direitos humanos, o que, no que tange aos direitos sociais, só pode ocorrer mediante a participação ativa do Estado.

De acordo com esse entendimento, a Constituição dos países, as declarações internacionais e a própria legislação ordinária são as principais referências para a orientação dessas políticas. Todavia, elas nem sempre são seguidas.

No Brasil, embora a Constituição Federal de 1988 seja relativamente pródiga em anunciar direitos sociais, o descompasso entre o declarado e o cumprido é evidente. Nesse contexto, torna-se importante avaliar se, apesar da irrestrita vinculação das políticas sociais aos mandamentos neoliberais de controle da pobreza, o cumprimento de normativas internacionais é possível e se o debate global relacionado à cidadania oferece reais contribuições para a efetivação de direitos, mediante a implementação de políticas sociais públicas.

É válido salientar também que não são apenas as normativas externas e internas que definem os rumos das políticas sociais. Mais do que elas, cujo papel é instrumental, a mobilização social e o controle democrático dos atos e das ações dos governos são essenciais, o que se relaciona com a participação política que alguns entendem como empoderamento.

Por ocasião da 51 a Sessão da Comissão de Desenvolvimento Social das Nações Unidas, em fevereiro de 2013, discutiu-se muito a respeito da importância do empoderamento como estratégia para retirar as pessoas da pobreza. E, por empoderamento, entendia-se a participação efetiva dos indivíduos e grupos nas decisões que afetam as dimensões sociais, legais, políticas e econômicas de suas vidas e está integralmente ligada à erradicação da pobreza, ao trabalho decente e à integração social. Com base nesse parâmetro, foi recomendado nas exposições do evento (ONU, 2013) o seguinte:

- Investir na educação, trabalhar para promover o bem comum, mediante mecanismos que permitam a participação de todos os cidadãos em âmbito local e nacional na vida social, política e econômica de suas sociedades;

- Implementar a Recomendação 202 da Organização Internacional do Trabalho - OIT, que estabelece um piso nacional de proteção social como um meio eficaz de capacitar as pessoas e reduzir a pobreza e as desigualdades; 
- Trabalhar para implementar os princípios orientadores, recentemente adotados, sobre pobreza extrema e direitos humanos;

- Promover a capacitação legal de todas as pessoas, especialmente aquelas que vivem em extrema pobreza, assegurando-Ihes o acesso aos direitos à justiça, à propriedade, à proteção trabalhista, ao registro de nascimento e documentos de identidade;

- Implementar a agenda da Organização Internacional do Trabalho - OIT referente ao trabalho decente e seu Pacto Global pelo Emprego; incentivar e garantir o pleno emprego e segurança de renda; ${ }^{1}$

- Iniciar a transição para fontes de energia de baixo carbono ligadas a um consumo mais ecológico e para promoção de tecnologias energicamente eficientes;

- Estimular as pessoas a se tornarem agentes de mudanças em suas sociedades no exercício de seus direitos e bem-estar;

- Desenvolver políticas públicas que incidam sobre o uso e desenvolvimento de tecnologias de informação e comunicação (TIC);

- Desenvolver infraestrutura tecnológica e de acesso público, a qual deve ser reforçada como um meio concreto para capacitar sociedades;

- Trabalhar para ampliar as fontes de financiamento inovadoras para o desenvolvimento, nomeadamente por meio da implementação de um imposto sobre transações financeiras, do Fundo Mundial para Proteção Social e da redução de gastos militares.

Essas recomendações demonstram a importância de os países investirem no que é chamado de capital social, ambiental e econômico. Esses aspectos são relevantes para o empoderamento do capital humano e como alternativa para a diminuição da pobreza e para o desenvolvimento das comunidades.

Todavia, cabe observar que, embora a linguagem utilizada no parágrafo anterior esteja em conformidade com a tradição do pensamento reformista, que não questiona o capitalismo, mas, ao contrário, intenta elevar a sua reprodução, o uso ipsis literis dessa linguagem neste estudo tem dois propósitos: a) revelar a noção de política de proteção social que prevalece nas normativas internacionais; e b) mostrar que, apesar de essa noção pertencer ao pensamento reformista capitalista, ainda assim constitui um avanço, se comparado com as negligências atualmente existentes no âmbito de proteção social dos idosos.

\footnotetext{
${ }^{1}$ Pacto Global para enfrentar a crise mundial de emprego com políticas que estejam alinhadas com o Programa de Trabalho Decente/OIT-98ª Conferência Internacional do Trabalho.
} 
Da estrutura da Organização das Nações Unidas, o Conselho de Desenvolvimento Social faz parte com a função de assessorar os governos a erradicar a pobreza e a estimular o trabalho decente para todos, no marco do desenvolvimento social sustentável com metas concretas, e examinar seus veículos de empoderamento. Com o advento do envelhecimento populacional, esse Conselho incluiu na sua agenda as discussões sobre os direitos da população idosa.

Em sessão realizada por esse Conselho, foi feita a avaliação do seguimento do Plano de Ação Internacional para o Envelhecimento (2002), também conhecido como Plano de Madrid sobre Envelhecimento. Esse documento pautou questões como os avanços comuns, os desafios, o abuso e a violência contra a pessoa idosa, o trabalho, além de recomendar maior atenção sobre o envelhecimento e a mobilização de recursos humanos e financeiros. Ainda nesse documento, a Comissão Econômica para América Latina e Caribe - CEPAL, assim como a União Europeia, a Ásia, a África, os países árabes e os Estados Unidos, apresentou os avanços nas suas regiões.

O Brasil, por intermédio de sua missão junto à Organização das Nações Unidas, apresentou suas políticas de distribuição de renda como um grande avanço na diminuição da pobreza. No entanto, embora nessas políticas não tenham sido destacadas ações específicas em prol das pessoas idosas, vale ressaltar que o referido avanço engloba o conjunto de iniciativas implementadas que, indiretamente, os atingem, a saber: o Benefício de Prestação Continuada - BPC, as pensões e aposentadorias rurais e a cobertura previdenciária, que abarca $82 \%$ da população com 60 anos e mais de idade (MPS, 2014). Porém, não foi explicitado que, em relação aos serviços, o país não oferece atendimento em espaços adequados aos idosos, em especial aos dependentes, seja no âmbito da saúde, da assistência, do esporte, da justiça, dentre outros.

A fragilidade na oferta de serviços é um aspecto que merece atenção no contexto do envelhecimento e das mudanças nos arranjos familiares. Nas sociedades contemporâneas, a mulher, a quem sempre coube o cuidado com a família, teve e quis sair, como uma opção legítima, para o mercado de trabalho e, com isso, as pessoas em situação de dependência tendem a ficar desassistidas no recinto doméstico. Isso torna imperiosa a necessidade de criação de políticas públicas destinada a esse público-alvo como um todo, incluindo as mulheres trabalhadoras, especialmente referentes aos cuidados de longa duração.

Dean (2006) afirma que é possível, por meio da política social, compensar as dependências que a sociedade contemporânea produz, o que explicita a importância dessa política e a responsabilidade do Estado na sua provisão, além de evidenciar que política social não só estuda o bem-estar humano, mas também contribui para esse bem-estar. 
O sociólogo inglês T.H Marshall (1967) divide a cidadania em três elementos: civil, surgido no século XVIII; político, no século XIX; e social, no século XX. E afirma que houve um entrelaçamento considerável entre o direito político e o social. Para ele:

O elemento civil é composto dos direitos necessários à liberdade individual - liberdade de ir e vir, liberdade de pensamento e fé, o direito à propriedade e de concluir contratos validos e o direito à Justiça.

Por elemento político se deve entender o direito de participar no exercício do poder político, como membro de um organismo investido da autoridade política ou como um eleitor dos membros de tal organismo (MARSHALL, 1967, p. 63).

O elemento social se refere tudo o que vai desde o direito a um mínimo de bem-estar econômico e segurança ao direito de participar, por completo, na herança social e levar a vida de um ser civilizado de acordo com os padrões que prevalece uma sociedade. As instituições mais intimamente ligadas com ele são o sistema educacional e serviços sociais (MARSHALL, 1967, p. 64).

Em épocas pré-capitalistas, os direitos sociais, segundo o mesmo autor, eram oriundos da participação da comunidade. Mas, gradativamente, foram se dissolvendo, em decorrência das mudanças econômicas, até o ponto em que nada restou senão a Lei dos Pobres, de 1834. De cunho liberal, essa Lei reformulou as Leis dos Pobres anteriores, adquirindo base nacional. Nesse processo, duas consequências importantes se fizeram notar: a primeira, "quando as instituições, dos quais os três elementos da cidadania dependiam, se desligaram" (MARSHALL, 1967, p. 65), cada uma seguindo um rumo particular e somente se reaproximando no século XX. A segunda residiu no fato de que "as instituições que eram de caráter nacional e especializado não poderiam pertencer tão intimamente à vida dos grupos sociais que elas serviam como aquelas que eram locais ou de caráter geral" (MARSHALL, 1967, p. 65).

Com o desmembramento dos três elementos da cidadania, eles se tornaram estranhos entre si e só foram claramente constituídos em séculos diferentes. Marshall define a cidadania como "um status concedido àqueles que são membros integrais de uma comunidade, todos aqueles que possuem status são iguais com respeito a direitos e obrigações pertinentes ao status" (MARSHALL, 1967, p. 76).

O crescimento da cidadania coincidiu com o desenvolvimento do capitalismo, que é um sistema de desigualdade, o que evidencia que, no mundo capitalista, a cidadania foi conquistada e muito se avançou com as lutas dos movimentos organizados para essa conquista. Como afirma Marshall:

[...] a cidadania exige um elo de natureza diferente, um sentimento direto de participação numa comunidade baseado numa lealdade e uma civilização que é um patrimônio comum. Compreende a lealdade de homens livres, 
imbuídos de direitos e protegidos por uma lei comum. Seu desenvolvimento é estimulado tanto pela luta para adquirir tais direitos quanto pelo gozo dos mesmos, uma vez adquiridos (MARSHALL, 1967, p. 84).

Portanto, a cidadania é um processo histórico acionado pelos homens, que redundou em aberturas políticas, aperfeiçoamento da democracia e extensão formal de direitos a todas as classes sociais.

No século $X X$, os indivíduos e a classe trabalhadora, em particular, tornaram-se mais organizados em associações e sindicatos; por isso, para Marshall,

[...] o método normal de assegurar direitos sociais é o exercício do poder político, pois os direitos sociais pressupõem um direito absoluto a um determinado padrão de civilização que depende apenas do cumprimento das obrigações gerais de cidadania (MARSHALL, 1967, p. 86).

Assim, a existência dos direitos civis e políticos contribuiu para o surgimento dos direitos sociais. Juntos, esses três conjuntos de direitos conformam a cidadania. Daí, afirmase que cidadania é um processo de construção permanente, baseado nas lutas e conquistas para garantir a todos, pelo menos, o direito formal à isonomia, isto é, à igualdade perante às leis. Nesse sentido, Barbalet (1989, p.12) entende que a cidadania pode ser descrita como participação numa comunidade ou como qualidade de membro dessa comunidade que engloba, além dos direitos, os deveres dos cidadãos.

A noção de cidadania, portanto, sempre se refere a práticas históricas conflitantes. Assim, os direitos que a compõem estão subjacentes ao processo de construção e de transformação social (JELIN, 2006, p. 159).

A esse respeito, Pisón (1998) esclarece que os direitos de cidadania surgiram à medida que os homens se viram diante de certas exigências básicas. Daí, segundo ele, a existência de três gerações de direitos: os de primeira geração - civis e políticos, conforme classificação de Marshall, reconhecidos nas primeiras Declarações de Direitos e, no século XIX, nas Constituições políticas. O artigo $1^{\circ}$ da Declaração Francesa, de 1789, assim se refere a eles:

Parece no sólo una mera afirmación categórica, sino la perfección de un contrato por el que "todos los hombres nacen y permanecen libres e iguales en derechos". Y el articulo 2 [indican] cuáles son esos derechos naturales y imprescriptibles y fundamentadores de toda asociación política: la libertad, la propiedad, la seguridad y la resistencia a la opresión (PISÓN, 1998, p. 71).

Foi por meio dos direitos civis e políticos que os movimentos democráticos conquistaram, contra o Estado absolutista do século XVIII, o poder de impor limites às arbitrariedades do monarca, que incluíam torturas, prisões indevidas, dentre outros atos imperiais. 
La teoría de los derechos del hombre encuentra su justificación y sus primeras discusiones en la tradición del pensamiento jusnaturalista que, poco a poco, esbozó los grandes trazos de sus ideas básicas, aunque no logro su plasmación teórica moderna hasta la Escuela de Derecho natural racionalista y hasta la filosofía de Locke (PISÓN, 1998, p. 70).

É importante, porém, notar que esses movimentos políticos dos séculos XVII e XVIII eram também conhecidos como revoluções burguesas - promovidas pela classe social que ascendia com o desenvolvimento do capitalismo, em detrimento da nobreza já decadente. Nesse contexto, os detentores dos recursos materiais defendiam a igualdade entre os homens para que pudessem, também, ter acesso ao poder político.

Assim, o que importava era o reconhecimento jurídico, com despreocupação com os meios jurisdicionais de proteção e das condições sociais e econômicas de quem devia exercê-los. Entretanto, no final do século XIX, no bojo da Revolução Industrial, surgiram movimentos reivindicatórios de massa, pleiteando mudanças de orientação dos direitos dos homens em direção à ampliação da igualdade e conquistando legislação social e políticas protetivas contra os rigores do processo de exploração do trabalho assalariado, que, então, tornava-se imprescindível à acumulação de riqueza privada.

A partir daí, surgem, conforme Pisón, os direitos de segunda geração, que são os direitos econômicos, sociais e culturais reconhecidos baseados da constatação de que a mera adoção, pelas leis, da igualdade formal não era suficiente para viabilizar a eficácia dos direitos. Assim, restava assentada a máxima de que a verdadeira igualmente se faz quando os desiguais são tratados desigualmente, isto é, de acordo com as suas necessidades.

Em momento posterior, surgiram os direitos de terceira geração, chamados difusos pelo fato de seus titulares serem cidadãos do mundo inteiro e pela indefinição a respeito de qual instituição mundial os garantiria. Deles são exemplos: o direito à paz, ao meio ambiente saudável, à determinação dos povos, entre outros, que estão associados à solidariedade e à fraternidade e buscam garantir direitos não apenas das gerações presentes, mas também das futuras.

Em 10 de dezembro de 1948, os direitos de primeira, segunda e terceira gerações foram reconhecidos na Declaração Universal dos Direitos Humanos, proclamada pela Resolução nำ 217 A (III) da Assembleia Geral das Nações Unidas e firmada pelo Brasil na mesma data (SEDH, 2006, p. 41). Em seu artigo $1^{\circ}$, essa Declaração dispõe que "todos os homens nascem livres e iguais em dignidade e direitos. São dotados de razão e consciência e devem agir em relação uns aos outros com espírito de fraternidade".

"A construção da cidadania no Brasil ganhou ímpeto após o fim da ditadura militar, em 1985. Uma das marcas desse esforço [foi] a voga que assumiu a palavra cidadania" (CARVALHO, 2009, p. 7). Os movimentos sociais organizados pleitearam e conquistaram a 
democracia e a Constituição Federal, promulgada em 1988, passou a ser conhecida como Constituição Cidadã. De acordo com Carvalho (2009), a partir de então não se diz mais "o povo quer isto ou aquilo", diz-se "a cidadania quer". Todavia, é preciso ter claro, conforme o mesmo autor, que, na prática, a cidadania se estratifica e essa estratificação produz a seguinte realidade típica em sociedades divididas em classe: "o cidadão pleno seria aquele que fosse titular dos três direitos. Cidadãos incompletos seriam os que possuíssem apenas alguns direitos. Os que não se beneficiassem de nenhum dos direitos seriam não-cidadãos" (CARVALHO, 2009, p. 9).

Como se vê, a garantia dos direitos conquistados exige, para a sua materialização, lutas constantes, "sobretudo diante da mais recente crise do capital, que vem solapando direitos conquistados árdua e historicamente" (BOSCHETTI, 2010, p. 64).

No Brasil, em que pese a conquista da cidadania, o cidadão ainda enfrenta sérios problemas nas áreas da saúde, educação, segurança pública, transportes, que estão diretamente associados ao aumento da desigualdade social e à concentração de renda. Enfim, há um quadro secular de difícil reversão, porém, não impossível, caso haja permanente pressão da sociedade organizada e controle democrático das decisões e das ações do bloco no poder.

De acordo com Bobbio (2004, p. 209), "a luta pelos direitos teve como primeiro adversário o poder religioso; depois, o poder político; e, por fim, o poder econômico." Hoje, percebe-se que os adversários históricos ainda se fazem presentes, criando barreiras, as quais, em muitas circunstâncias, chegam a ser instransponíveis.

Como mostra a história da evolução dos direitos humanos, o cidadão foi ampliando, aos poucos, suas conquistas na esfera da cidadania sem conseguir garantir, até hoje, em sua plenitude, a eficácia de todos os direitos. A segunda geração não surgiu da plena eficácia da primeira, assim como a terceira não apareceu só depois que todos os cidadãos tiveram seus direitos de segunda geração assegurados. Porém, nesse processo, pode-se perceber uma expansão da consciência acerca do papel do cidadão na sociedade, não apenas na esfera política, mas também nas esferas civil e social.

A ampliação do rol dos direitos representa, na verdade, um aumento da agenda pela qual lutam os movimentos sociais, com o objetivo de garantir tanto a efetiva cidadania, quanto a dignidade da pessoa humana.

E, não obstante o lapso entre a criação dos direitos e sua eficácia, é possível perceber que o reconhecimento e a inscrição desses direitos em instrumentos juridicamente vinculantes de caráter internacional, contando com o aval de várias nações, têm-se constituído em uma forma relevante de luta pela eficácia desses direitos. 


\subsection{MOVIMENTOS SOCIAIS}

Como já assinalado, os movimentos associados aos direitos sociais surgiram no século XIX para reivindicar maior igualdade. De acordo com Pisón (1998), o surgimento desses movimentos está também ligado ao desenvolvimento da sociedade capitalista durante o século XIX e ao fortalecimento de uma nova classe social, o proletariado, que tinha como principal pleito a melhoria de suas condições de vida e de trabalho. Tratava-se, portanto, de ações coletivas mobilizadas em torno de um objetivo comum e indicadoras de que, só por meio da organização política, a sociedade teria maior poder de conquista.

Além disso, causas econômicas e sociais produziram significativas mudanças na configuração do Estado liberal, o qual não interferia na vida econômica nem no fluxo de mercado, que produziam, progressivamente, desigualdades sociais.

Consequentemente, com o advento do capitalismo monopolista, os novos movimentos sociais e as lutas trabalhistas aumentaram as tensões entre capital e trabalho, contribuindo para a criação do Estado Social que se consolidou após a Segunda Guerra Mundial.

No século $\mathrm{XXI}$, novos atores entraram em cena sob a forma de movimentos sociais globais, fóruns, conselhos, câmaras de participação, ao mesmo tempo em que novas lutas sociais se internacionalizam em prol da efetivação dos direitos do cidadão. $O$ associativismo se consolidou, desse modo, como a tendência contemporânea de grupos. Assim, os movimentos sociais articularam-se em redes graças ao avanço dos meios midiáticos e informacionais.

Em conformidade com Touraine (apud GOHN, 2010, p.12), cabe identificar e considerar os sujeitos que estão em discussão neste cenário tão amplo. As atuais formas de associações civis organizadas em redes podem ser agrupadas em três grandes blocos:

- Os movimentos de ações de grupos identitários que lutam por direitos sociais, econômicos, políticos, e, mais recentemente, culturais. São movimentos sociais excluídos, geralmente de camadas mais populares, mas não exclusivamente;

- Os movimentos e organizações de lutas por melhores condições de vida e de trabalho no meio urbano e rural, que demandam acesso a terra, moradia, alimentação, saúde, transportes, lazer, salários etc.;

- Os movimentos globais ou globalizantes que atuam em redes sociopolíticas e culturais via fóruns, plenárias, colegiados, conselhos etc., em âmbitos locais, regionais, nacionais ou transnacionais.

No mundo globalizado dos dias de hoje, são crescentes os movimentos sociais que se organizam em redes em decorrência das mudanças organizacionais, políticas e 
tecnológicas. Não tendo o Estado poder de restringir a ação coletiva, as redes de comunicação fortalecem-se e possibilitam a expansão de conhecimento e sua penetração em âmbito global. Conforme Gohn (2010):

\begin{abstract}
Os movimentos sociais na atualidade são distintos tanto daqueles que levaram à sua emergência na cena pública no século XIX e nas primeiras décadas do século XX (movimento operário e movimentos revolucionários desde a Revolução Francesa), como dos movimentos que emergiram nos Estados Unidos nos anos 1960 (direitos civis, feminismo, contra a guerra do Vietnã, estudantil etc.). Na América Latina, especialmente no Brasil, os atuais movimentos sociais são distintos dos movimentos que ocorreram na fase do regime político populista. São diferentes também dos movimentos ocorridos do final da década de 1970 e parte dos anos e 1980 (movimentos populares reivindicatórios e melhorias urbanas articulados com pastorais, grupos políticos de oposição ao regime militar etc.), embora muitos dos atuais movimentos sejam herdeiros daqueles dos anos 1980 (GOHN, 2010, p. 170)
\end{abstract}

Nesse contexto, a mobilização popular e os movimentos sociais foram se fortalecendo de maneira a expressar, com mais intensidade, suas reivindicações sociais, políticas e culturais. A sociedade civil começou a se organizar em busca de conquistas de cidadania, destacando-se, em torno dessa busca, o movimento dos aposentados e pensionistas.

As organizações não governamentais de defesa dos direitos da pessoa idosa em âmbito mundial têm participado ativamente, como força política, de um pleito global para a criação de um Consenso de proteção social. Desse movimento, prevê-se a participação do UNICEF, do Banco Mundial ou de um Conselho Internacional de Bem-estar Social que dê oportunidade às pessoas idosas de acessarem bens e serviços e terem proteção baseada na solidariedade, além de suporte financeiro internacional com recursos provenientes de impostos.

No Brasil, um dos movimentos sociais que, a cada dia, vem se fortalecendo e ganhando adeptos é o dos aposentados, pensionistas e idosos. Esse movimento criou, no dia 13 de outubro de 1985, por ocasião da IX Congresso Nacional dos Aposentados e Pensionistas, a Confederação Brasileira dos Aposentados e Pensionistas - COBAP, com as seguintes finalidades: congregar e representar os aposentados, pensionistas e pessoas idosas; promover ações coletivas que visem o bem-estar de seus associados; contribuir com ações nas áreas de saúde, lazer, cultura, educação, dentre outras, para o exercício pleno da cidadania do idoso (site COBAP, 2011); e desenvolver políticas e ações junto às entidades de base, com o fim de resgatar o poder aquisitivo, a dignidade e o respeito aos aposentados, pensionistas e idosos.

A COBAP anualmente realiza congressos nacionais e participa de eventos com o objetivo de não só intercambiar experiências entre as Federações e Associações a ela vinculadas, mas também de discutir temas de interesse dos participantes. Tem 
frequentemente participado de reuniões e de encontros com gestores públicos, sobretudo os da previdência, saúde e assistência social, com o objetivo de discutir temas que beneficiem os aposentados, pensionistas e pessoas idosas. A atuação da COBAP junto ao Poder Legislativo também tem sido relevante com vista à conquista dos direitos.

Por ocasião do XXII Congresso Nacional de Aposentados, Pensionistas e Idosos, em outubro de 2013, em Camboriú, Santa Catarina, foi aprovada por unanimidade a Carta Compromisso, pela plenária de representantes de entidades de todo território nacional, reivindicando a inclusão nos planos de governo dos candidatos à Presidência da República as seguintes propostas:

- Participação efetiva da COBAP nas tomadas de decisões relativas à Previdência Social;

- Fim da Desvinculação da Receita da União - DRU e da desoneração da folha de pagamentos, bem como a devolução, com transparência, dos valores da Previdência já utilizados;

- Reajustes dos benefícios acima do piso com o mesmo índice concedido ao salário mínimo nacional;

- Fim do Fator Previdenciário e respectivo ressarcimento àqueles que se aposentaram nos últimos 5 anos;

- Criação do Banco da Seguridade Social, para gerir os recursos oriundos das contribuições sociais, com gestão quadripartite;

- Regulamentação da desaposentação;

- Recuperação das perdas salariais, assistência médica de qualidade preferencial aos aposentados, pensionistas e idosos brasileiros;

- Criação da Secretaria Nacional dos Aposentados, Pensionistas e Idosos do Brasil, com participação efetiva da COBAP.

Além da COBAP, as Federações e os Sindicatos de Aposentados e Pensionistas, a Central Única de Trabalhadores - CUT, a Confederação dos Trabalhadores da Agricultura CONTAG e a União Geral de Trabalhadores - UGT vêm participando ativamente das reuniões do GT com setores de aposentados das Centrais Sindicais, coordenadas pelo Ministério da Previdência e contando com a participação do Ministro-Chefe da Casa Civil da Presidência da República.

Dentre as reivindicações apresentadas nessas reuniões, ressalta-se a reativação do Conselho Nacional de Seguridade Social, cuja resolução já foi aprovada pelo Conselho 
Nacional de Previdência Social. No entanto, tal Conselho terá caráter consultivo e atribuição de discutir a política de Seguridade Social, especialmente nas áreas de segurança e saúde do trabalhador; das pessoas idosas; das pessoas com deficiência; das mulheres e da igualdade racial. Além disso, visa discutir o orçamento da Seguridade Social.

Foram criadas, ainda, no Brasil, as associações e as federações de aposentados e pensionistas com o objetivo de lutar pelos direitos de seus associados e por melhores aposentadorias e pensões. Um exemplo é o da Associação dos Aposentados e Pensionistas de Volta Redonda - Rio de Janeiro, criada em 1973. Essa instituição, além de zelar pelos interesses de seus associados, proporciona serviços e ações nas áreas de saúde, assistência social, lazer, esporte e eventos diversos.

A participação dos idosos nesse processo é imperiosa, pois, de acordo com Gohn (2008), ele:

[...] imprime sentido e significado [a sua luta] tornando-o protagonista de sua história, desenvolvendo uma consciência crítica desalienadora, agregando força sociopolítica a esse grupo ou ação coletiva, e gerando novos valores e uma cultura política nova (GOHN, 2008, p. 30).

Para Gohn (2008), portanto, a participação cidadã leva à mudança e à transformação social. Também os sujeitos coletivos precisam de orientação e saberem o que realmente querem. Nesse sentido, também cabe mencionar o Grupo de Articulação para Conquista de Moradia do Idoso da Capital - GARMIC. Criado em 1999, no município de São Paulo, o grupo já conquistou 145 moradias, atendendo a 200 idosos com renda de 1 a 3 salários mínimos. As moradias são construídas em sistema de locação social e os moradores pagam mensalmente $10 \%$ de sua renda. O grupo é filiado à União Nacional de Moradia Popular, o qual tem assento no Conselho Nacional das Cidades. Por seu intermédio, o GARMIC conquistou mais 500 moradias para os idosos do Programa Minha Casa Minha Vida.

Uma das conquistas mais relevantes e históricas do movimento dos aposentados e pensionistas foi a mobilização, em âmbito nacional, pelo reajuste das pensões e aposentadorias em 147\%, que haviam sido expurgadas pelo governo Collor, no início do ano de 1990. Os aposentados e pensionistas do Estado de Santa Catarina decidiram fazer caravana, partindo da cidade de Criciúma até a capital Florianópolis, para pedir apoio à Câmara Legislativa e ao governador daquele Estado, uma vez que já existiam decisões do Poder Judiciário a favor do referido reajuste. Porém, a surpresa: a ponte que liga a ilha ao continente estava bloqueada para que a caravana não pudesse passar. Os participantes tentaram conversar com a Polícia Militar que fazia o bloqueio, informando que a mobilização era pacífica; no entanto, não houve acordo. Mesmo assim, a caravana furou o bloqueio, chegando ao Palácio do Governador, apesar de muitos participantes terem sido feridos. Em 
22 de fevereiro de 1992, o Supremo Tribunal Federal deu ganho de causa aos aposentados e pensionistas.

Outra conquista obtida por meio de lutas sociais foi a Política Nacional do Idoso, instituída pela Lei no 8.842 , de 4 de janeiro de 1994. Essa Lei tem por objetivo assegurar os direitos do idoso à autonomia, integração e participação efetiva na sociedade. Sua elaboração e posterior promulgação resultaram de reivindicações da sociedade, sob a liderança da Associação Nacional de Gerontologia. Para tanto, essa entidade realizou três seminários regionais nas cidades de Goiás, Maranhão e Distrito Federal e um nacional. Participaram desses eventos: aposentados, idosos, profissionais das áreas de geriatria e gerontologia e pessoas interessadas na causa. A Associação Nacional de Gerontologia produziu o documento intitulado Recomendações sobre Políticas Sociais para o Idoso nos anos 1990. Esse documento foi entregue ao Governo Federal, sendo amplamente discutido entre as organizações governamentais e não governamentais, e redundando em um Projeto de Lei. Este, posteriormente, foi transformado na Lei supracitada. Essa Lei foi regulamentada pelo Decreto № 1.948, de 3 de julho de 1996.

Cabe ainda mencionar e elencar no rol de conquistas dos aposentados, pensionistas e idosos a elaboração da minuta do Estatuto do Idoso (EI), realizada pelas federações estaduais de defesa de direitos das pessoas idosas e consolidada pela COBAP. A minuta foi entregue ao então Deputado Paulo Paim, para subsidiar o Projeto de Lei que deu origem ao El. Em 1997, o referido Projeto de Lei começou a tramitar na Câmara Federal, subsidiado pelo documento consolidado pela COBAP; e, em torno dessa tramitação, numerosos eventos foram realizados na Comissão de Seguridade da Câmara Federal. Outros foram promovidos pela Câmara Distrital de Brasília e de outros estados da Federação, com a participação de aposentados, pensionistas, pessoas idosas, organizações governamentais, não- governamentais, instituições de ensino superior e Ministério Público. Em suma, após sete anos de luta, os aposentados conquistaram a Lei $n^{\circ} 10.741$, que foi sancionada em $1^{\circ}$ de outubro de 2003. Essa data é significativa por ter sido instituída pela Organização das Nações Unidas, como o Dia Internacional do Idoso. No Brasil, esse dia passou a vigorar também como o Dia Nacional do Idoso, em conformidade à Lei no 11.433, de 28 de dezembro de 2006.

O Estatuto do Idoso regula os direitos assegurados às pessoas com 60 e mais anos de idade. Trata-se de uma lei que se pauta pelas orientações do II Plano Internacional para o Envelhecimento, resultante da II Assembleia Mundial do Envelhecimento, realizada em Madrid, em 2002, pela Organização das Nações Unidas. 
Em 2014, a COBAP, as Federações e Entidades de Base organizaram-se com o objetivo de cumprir uma agenda de mobilização nacional. Esse movimento surgiu da necessidade de luta pela aprovação do Projeto de Lei no 4.434, de 2008, que corrige as aposentadorias do INSS de acordo com o número de salários mínimos da época da concessão, e da PEC no 555, de 2006, que extingue a cobrança da contribuição da Previdência Social dos aposentados e pensionistas do serviço público. A mobilização teve início no mês de janeiro, em Aparecida - SP, com uma missa, seguida de passeata e paralisação na Via Dutra. No mês de março, no dia da Mobilização Nacional, em vários Estados do país, foram realizadas as visitas dos dirigentes e diretores das federações a parlamentares, pedindo apoio à aprovação do referido Projeto de Lei.

A agenda de mobilização nacional ganhou forças e ocupou as ruas no dia 5 de agosto, com o lançamento do UMA - SE (Movimento Unificado dos Aposentados, Pensionistas e Idosos do INSS e do Serviço Público), organizada pela COBAP, ANFIP, MOSAP e outras instituições filiadas, realizando-se grande ato em Brasília, no Plenário da Câmara Federal, por ocasião da reunião da Frente Parlamentar em Defesa dos Aposentados e Pensionistas.

Vale lembrar, também, o 1ํㅡㄹ Encontro Nacional de Federações e Entidades de Base, que aconteceu em Natal - Rio Grande do Norte, reunindo mais de 600 lideranças de todo o Brasil para debater os direitos dos aposentados e idosos. No entanto, todos esses movimentos não despertaram, ainda, para a luta por uma cobertura de serviços para as pessoas idosas dependentes.

\subsection{ENVELHECIMENTO CUIDADOS E DEPENDÊNCIA}

O envelhecimento populacional decorre de uma série de fatores. A diminuição da taxa de fecundidade e de mortalidade é um dos mais importantes. O aumento da expectativa de vida dos indivíduos deve-se, preponderantemente, aos avanços da medicina, da tecnologia e da mudança de hábitos das pessoas idosas. Hoje, no Brasil, as pessoas estão vivendo mais: em média 73 anos de idade, sendo considerável o aumento daquelas com sessenta anos e mais.

Para Camarano (2011), o envelhecimento individual ocorre à medida que a pessoa envelhece; esse processo é irreversível, natural e acompanhado de perdas progressivas de funções e de papéis sociais. Já o envelhecimento populacional ocorre quando aumenta a participação da população idosa no total da população.

O envelhecimento populacional, no Brasil e no mundo, é, como já foi salientado, uma realidade incontestável, cujos efeitos já se fazem notar nos sistemas econômicos, sociais e 
políticos das nações. E, consequentemente, vem contribuindo para maior representação numérica e peso político das pessoas idosas na sociedade.

A questão da velhice não está associada apenas ao processo demográfico. Está inserida na produção das diferentes formas de relações sociais e, por isso, interroga os poderes públicos e a sociedade como um todo.

O assim chamado fenômeno do envelhecimento não tem uma explicação em si mesmo, nem é inócuo. O aumento da longevidade, além de conter várias determinações, implica queda da população economicamente ativa. Como diz Esping-Andersen (2011, p. 101), tal aumento poderá traduzir-se por uma queda na demanda agregada e da produtividade; e, ainda, "o envelhecimento nos expõe a outra ameaça iminente: a do choque intergeracional".

As reformas previdenciárias, neste contexto, têm sido bastante debatidas no cenário político nacional. A transição demográfica exige mudanças, visando assegurar aposentadorias e pensões. Entretanto, com a redução da população ativa, a carga para manutenção dessas políticas recairá pesadamente sob os ombros dessa população.

Para entender a importância dos cuidados a serem prestados à pessoa idosa dependente é importante reiterar que "o envelhecimento manifesta-se pelo declínio das funções dos órgãos que, caracteristicamente, tende a ser linear em função do tempo, não permitindo a definição de um ponto exato de transição, como nas demais fases" (NETTO, 2007, p. 6).

A velhice é uma fase da vida que, em função do tempo, produz o declínio das funções orgânicas. Por isso, para que uma pessoa envelheça com qualidade, deve investir, desde cedo, em atividades que estimulem sua capacidade funcional. Essas funções orgânicas variam entre os idosos; ou seja, o envelhecimento não é igual para todos, devendo ser levados em consideração o meio ambiente, o fator genético, os hábitos de vida, as causas psicossociais, culturais, dentre outros fatores.

Conforme Netto (2007, p. 34), "o envelhecimento (processo), a velhice (fase da vida) e o velho ou idoso (resultado final) são componentes que estão intimamente relacionados". Esse autor complementa que:

Pode-se considerar o envelhecimento, como admite a maioria dos biogerontologistas, como a fase de um todo continuum que é a vida, começando esta com a concepção e terminando com a morte. Ao longo desse continuum, é possível observar fases de desenvolvimento, puberdade e maturidade, entre as quais podem ser identificados marcadores biofisiológicos que representam limites de transição entre as mesmas. $O$ exemplo é a menarca como marcador do início da puberdade na mulher; ao contrário do que acontece com as outras fases, o envelhecimento não possui um marcador biofisiológico do seu início, por motivos já expostos. De 
qualquer forma, a demarcação entre maturidade e envelhecimento, à qual este período aparente segue, é arbitrariamente fixada mais por fatores socioeconômicos e legais do que pelos biológicos (NETTO, 2007, p. 35).

Um exemplo da relação entre idade e fatores socioeconômicos e legais é apresentada pela Organização Mundial de Saúde, que considera idosa a pessoa com 60 anos e mais de idade em países em desenvolvimento e com 65 anos as que vivem em países desenvolvidos. Outro exemplo é o Brasil, cujas políticas de defesa dos direitos das pessoas idosas consideram idosa a pessoa com 60 anos e mais de idade; e, para fins de distribuição de benefícios, as com 65 anos e mais e mais de idade.

Sabe-se que a população socialmente menos favorecida, com maiores dificuldades em relação à saúde, ao meio ambiente saudável, ao nível socioeconômico, envelhece mais rapidamente. Portanto, classificar o envelhecimento por idade sem considerar a produção social do processo de envelhecimento humano induz ao negligenciamento dos direitos sociais. Como afirma Netto:

[...] se o início da velhice é rigorosamente indefinido e, portanto, torna-se difícil tentar fixá-lo, maior dificuldade talvez resida nas diferentes formas como a sociedade vê o fenômeno e o idoso: preconceituosa com aqueles que têm origem nas classes sociais mais baixas, benevolentes para os que ocupam classes sociais mais elevadas (NETTO, 2007, p. 35).

Para Freitas et al. (2006), se for considerado apenas o aspecto fisiológico, o envelhecimento:

[...] é caracterizado por uma limitação de capacidade de cada sistema em manter o equilíbrio do organismo. O declínio fisiológico tem início após a terceira década de vida, sofrendo a influência dos fatores genéticos, do meio ambiente e dos fatores de risco. Isto significa que podemos modificar, até certo ponto, as características do envelhecimento, agindo sobre esses fatores (FREITAS, 2003 apud FREITAS et al., 2006, p. 25).

Mas, "o até certo ponto que pode ser modificado" depende muito dos hábitos de vida de cada um; o uso do fumo e do álcool são fatores de risco. Entretanto, apesar de não se ter como decidir sobre o envelhecimento de cada um, é possível investir na qualidade de vida por meio de ações que realizem a prevenção de doenças, a promoção saúde e a educação para uma vida saudável e ativa.

É como reforça Fericgla (1992, p. 65):

[...] el proceso de envejecimiento humano empieza muy pronto en relación a la duración cronológica de la vida, y se manifiesta en hecho como el progresivo endurecimiento de determinados tejidos, la aparición de canas, la perdida general de flexibilidad y otros cambios progresivos ampliamente estudiados por la medicina. Sin embargo, este proceso comienza a hacerse patente en el segundo o tercer decenio de vida y nadie afirma que una persona de 30 años es vieja por estos motivos (por ejemplo, se le aparece canas). Es decir, el envejecimiento en el sentido psicobiológico es un proceso lento de pérdidas de capacidades corporales que empieza a los 20 30 años, pero, en cambio, lo que se entendí por vejez es una cuestión 
cultural y social, y por tanto relativamente desvinculada de la evolución biológica.

Diante dessas argumentações, fica evidente que cada pessoa tem um modo de envelhecer e que nem todos são iguais, mesmo que participem de uma mesma cultura e tenham graus de parentesco. Mas, é válido observar que, biologicamente:

[...] o envelhecimento compreende os processos de transformação do organismo que ocorrem após a maturação sexual e que implica a diminuição gradual da probabilidade de sobrevivência. Esses processos são de natureza interacional, iniciam-se em diferentes épocas e ritmos e acarretam resultados distintos para as diversas partes e funções do organismo suportar uma determinada quantidade de mutações. Esgotando esse limite, o organismo perece (NETTO, 2001, p. 43).

Atualmente, as pessoas idosas possuem mais chances de ter uma vida longa, principalmente as que desenvolvem uma gama de ações que lhes proporcionam bem-estar e qualidade de vida, como: atividades físicas, recreativas, culturais, intelectuais, políticas, relações sociais e espiritualidade. O saneamento básico, os avanços da medicina e da tecnologia muito contribuíram, como já comentado, para a longevidade. Tanto é assim que, há três décadas, quando as pessoas se aposentavam, elas só pensavam em descansar e tinham em média uma sobrevida de 3 a 5 anos. Hoje, porém, com o envelhecimento ativo e saudável, a sobrevida para os situados no interregno de 20 a 30 anos é maior. No entanto, existem pessoas idosas que apresentam graus de dependência, em que "as alterações funcionais próprias do envelhecimento associadas à maior prevalência de doenças crônicas podem levar a deterioração da habilidade de manutenção da independência" (NETTO,2001, Id., p. 9). Esse é um fator a ser especialmente levado em conta nesta tese, já que é um aspecto importante na discussão e na compreensão da política de cuidados.

Com efeito, a perda da capacidade funcional torna as pessoas idosas dependentes do apoio de terceiros para o desenvolvimento de suas atividades de vida diária. Essas atividades, conhecidas pela sigla AVDs:

[...] são didaticamente subdivididas em: a) básicas (ou ABVDs - atividades básicas de vida diária), relacionadas à capacidade de autocuidado (alimentar-se, banhar-se, vestir-se, arrumar-se, mobilizar-se, utilizar o banheiro para eliminação de forma independente e deambular); b) instrumentais (ou AIVDs - atividades instrumentais da vida diária): fazer compras, tomar os próprios medicamentos, utilizar transporte, cuidar da casa, administrar as próprias finanças, indicando a capacidade para levar uma vida comunitária independente (WILKINS; LAW; LETS, 2001, apud LEBRÃO; DUARTE, 2007, p. 200).

No contexto brasileiro, a Pesquisa Nacional por Amostra de Domicílio - PNAD/IBGE, de 2008, mostrou que, das pessoas idosas com 60 anos ou mais de idade, $15,9 \%$ declararam alguma dificuldade para realizar as atividades de vida diária (AVDs), como alimentar-se, tomar banho ou ir ao banheiro. 
Já o Censo de 2010 detectou que 13,6\% das pessoas com 60 anos ou mais de idade apresentavam grande dificuldade para enxergar, ouvir, acrescidos ao fato de que não conseguiam caminhar, subir escadas ou possuíam deficiência mental/intelectual permanente. Esse fato está relacionado a uma tendência contraditoriamente alvissareira na sua conquista, mas concomitantemente desafiadora nas suas exigências: o aumento do percentual de pessoas acima dos 80 anos de idade.

Segundo Camarano e Kanso (2010), projeções populacionais indicam o acentuado crescimento desse segmento etário. Todavia, com o aumento de seu percentual, também aumentam os graus de dependência para atividades de vida diária, assim como a necessidade de cuidados de longa duração, ainda muito incipientes em várias partes do mundo, incluindo-se o Brasil.

A Organização para Cooperação e Desenvolvimento Econômico - OCDE (apud CAMARANO, 2010, p. 15) define como política de cuidado de longa duração "uma política transversal que inclua um conjunto de serviços para pessoas que dependem de ajuda para AVD's por um longo período de tempo". Trata-se, em outras palavras, da "acción social dirigida a garantizar la supervivencia social y orgánica de las personas que carecen o han perdido la autonomía personal y que necesitan ayuda de otros para realizar los actos esenciales de la vida diaria" (HUENCHUAN, 2012, p, 61).

Cuidar, portanto, é uma tarefa que requer habilidade e formação adequada do cuidador para o trato com a pessoa idosa com dificuldades de desenvolver suas atividades cotidianas. Em vista disso, tanto o cuidador familiar, como o domiciliar ou formal, de pessoas idosas com graus de dependência, devem ter aptidão para desenvolver as atividades de cuidado.

Os cuidados de longa duração incluem as seguintes tarefas, ainda que não estejam limitadas unicamente a elas:

- Estimular a participação dos idosos na vida comunitária, social e familiar;

- Adaptar o entorno de sua casa e instalar dispositivos de assistência para compensar funções deterioradas;

- Assessorar e avaliar o estado de assistência social e de saúde dos mesmos, com vista a proporcionar planos explícitos de cuidados e um seguimento adequado por parte dos profissionais e auxiliares;

- Adotar programas para reduzir as deficiências e prevenir maiores dependências por meio de medidas que reduzam fatores de riscos; 
- Fazer uso da assistência em instituições quando necessário;

- Reconhecer e cobrir as necessidades espirituais, emocionais e psicológicas;

- Proporcionar cuidado paliativo adequado (OMS, 2002).

A atenção prestada em instituições de longa permanência está sendo uma das alternativas de cuidados aos idosos que apresentam algum grau de dependência com maior demanda. Os cuidados no domicílio, na maioria informal, são prestados pela família, pelos voluntários e pela própria comunidade; no entanto, as famílias geralmente não apresentam as mínimas condições físicas e financeiras para o exercício do cuidado. Com a saída da mulher para o mercado de trabalho, torna-se cada vez mais difícil a família arcar sozinha com a atenção requerida por parentes idosos dependentes.

No Brasil, como 65\% das instituições são filantrópicas, estas, na sua maioria, enfrentam sérios problemas em relação à adequação de estrutura física e de recursos humanos às normas vigentes ${ }^{2}$, como a RDC no 283 da Agência Nacional de Vigilância Sanitária.

Para Debert (2012, p.224), os entusiasmos das imagens gratificantes da Terceira Idade "levantaram uma verdadeira cortina de fumaça para as situações de dependência e perda da autonomia funcional que caracterizam as etapas mais avançadas do envelhecimento".

Essa cortina de fumaça impede a sociedade e o Estado de verem que a velhice sem dependência não é para todos e que o envelhecimento populacional já é uma realidade. Nesse contexto, a dependência, já reconhecida nos países desenvolvidos como um risco social requer medidas urgentes do Estado. No entanto, o Brasil, até o momento, não despertou para o drama vivido pelas famílias brasileiras com pessoas idosas dependentes e sem acesso a qualquer serviço.

As instituições de longa permanência para idosos - ILPI's, como uma das modalidades de maior atendimento às pessoas idosas dependentes, enfrentam dificuldades em razão dos altos custos para sua manutenção e para o cumprimento das legislações vigentes. Além disso, o número de entidades não é suficiente para atender a demanda por esses serviços.

As ILPIS foram criadas para dar abrigo aos idosos desamparados. Para tanto, devem ter equipe interdisciplinar e oferecer serviços que contemplem diversas atividades

\footnotetext{
${ }^{2}$ Estatuto do Idoso, Política Nacional do Idoso.
} 
estimuladoras da capacidade funcional dos residentes, além de garantir-lhes direitos assegurados nas legislações vigentes.

Contudo, os cuidados com as pessoas idosas enfrentam problemas nos diferentes países. De acordo com Huenchuan (2013, p. 62):

La Oficina Nacional de Derechos Humanos del Reino Unido, por ejemplo, puso de manifiesto que las personas mayores que reciben cuidados a largo plazo experimentan dificultades para ejercer sus derechos. Apoyándose en un estudio reciente, el organismo sostuvo que este grupo tenía poco o nada que decir sobre la forma en que quería vivir, y a menudo confundía las opciones de las que disponía. La mayoría de las personas mayores consideró que la discriminación por edad y el estigma asociado a la vejez eran muy frecuentes en el trato que recibían por parte del personal que les brindaba atención, y que se les concebía más como una mercancía que como ciudadanos con derechos. La atención domiciliaria tampoco está exenta de problemas. Una investigación llevada a cabo por la misma Oficina arrojó que la mitad de las personas mayores entrevistadas estaban insatisfechas con los servicios, eran maltratadas, no tenían suficiente apoyo para alimentarse o beber, no se les dedicaba el tiempo suficiente para atender todas sus necesidades, y con frecuencia se ignoraban sus requerimientos. Se quejaron de la falta de intimidad y el escaso respeto a su autonomía personal. Asimismo, a diferencia de lo que ocurre con el cuidado de los jóvenes, la atención domiciliaria de las personas de edad en escasas ocasiones incluye el apoyo para actividades sociales. La investigación reveló que ello les genera un sentimiento de aislamiento y soledad que afecta su bienestar físico y la confianza personal.

A Europa, como um continente mais envelhecido, vem se esforçando para adotar medidas que propiciem o bem-estar das pessoas idosas dependentes, tais como:

El Grupo de redacción sobre los derechos humanos de las personas mayores, del Comité Directivo para los Derechos Humanos del Consejo de Europa, ha hecho una contribución destacable en este sentido, al incluir en el capítulo de cuidados de su proyecto de Recomendación algunos elementos novedosos que pueden ser útiles para orientar con respecto a qué se debe proteger en este ámbito. En la Recomendación se reconocen y garantizan los derechos de las personas mayores que reciben cuidados; se distribuyen los costos del cuidado de forma más equitativa entre toda la sociedad y se fomenta el apoyo a las formas profesionales, decentemente remuneradas y sensibles de cuidado. Además, en este capítulo se incorporan la atención residencial e institucional y los cuidados paliativos. Con respecto a la primera, se recomienda lo siguiente:

- Las personas de edad que son colocadas en instituciones tienen derecho a la libertad de movimiento. Todas las restricciones deben ser legales, necesarias y proporcionadas, y de conformidad con el derecho internacional. Debe haber garantías suficientes para la revisión de estas decisiones. Los Estados miembros deben velar por que las restricciones individuales para una persona de edad se apliquen con su consentimiento libre e informado, o como una respuesta proporcionada a un riesgo de daño potencial.

- Los Estados miembros deben asegurarse de que exista una autoridad u organismo encargado de la inspección de las instituciones públicas y establecer mecanismos de denuncia fácilmente accesibles y eficaces y la reparación de las deficiencias en la calidad de la atención.

- En principio, las personas de edad solo se deben colocar en la atención residencial, institucional o psiquiátrica con su consentimiento libre e 
informado. Cualquier excepción a este principio deberá cumplir los requisitos del Convenio Europeo de Derechos Humanos, en particular el derecho a la libertad y a la seguridad (HUENCHUAN, 2013, p.73).

Os cuidados pessoais aos idosos dependentes demandam grande parte do tempo dos cuidadores que, em geral, são mulheres. Essa tarefa é desgastante e exige sacrifícios. $\mathrm{Na}$ Espanha, o modelo de cuidado informal, de acordo com Rodriguez Cabrero (2005), é intenso; algo mais que $62 \%$ das pessoas dependentes recebem cuidados pessoais por mais de 4 anos e quase $42 \%$ dos dependentes recebem atenção pessoal pelo cuidador principal por mais de 8 anos. A duração média de cuidados pessoais gira em torno de 6 anos, mas, no caso da família (os parentes em geral são os cuidadores), chega aos 6 anos e meio. Por isso, na avaliação desse autor, a dependência é um risco social que pode ser definida como:

[...] 'a necessidade de ajuda ou assistência importante para as atividades de vida cotidiana', ou de maneira mais precisa, como 'um estado' em que se encontram as pessoas que, por razões ligadas à falta ou perda de autonomia física, psíquica ou intelectual, têm necessidade de assistência e/ou ajudas importantes a fim de realizar as atividades de vida diária e, de modo particular, as que se referem aos cuidados pessoais (CONSEJO DE EUROPA apud LIBRO BLANCO, 2005, p.4, tradução nossa). ${ }^{3}$

Trata-se, nas próprias palavras do autor, da:

[...] extensión actual del problema y, sobre todo, la intensidad que va tener en los años venideros exige crear un sistema de protección social que aquí entendemos como un sistema de cobertura universal, integrado, coordenado y basado en el principio de igualdad (RODRIGUEZ CABRERO, 2005, p. 68).

Em suma, a dependência é considerada um risco social comprovado por dados demográficos. De acordo com esses dados, a partir de 2015, com o crescimento da população acima de 65 anos, aumentará, consequentemente, o número de pessoas que precisarão de cuidados. Nesse sentido:

[...] una proyección de la población dependiente en base a la proyección de la población general es relativamente engañosa ya que la clave de la proyección reside en la evolución de la esperanza de vida libre de discapacidad, todo ello sin tener en cuenta que la utilización de uno u de otro indicador sintético de discapacidades también afecta al volumen y estructura de de la población dependiente (RODRIGUEZ CABRERO et al., 2004 apud RODRIGUEZ CABRERO, 2007, p. 77).

Efetivamente, o arco da situação de dependência tende a se ampliar, inclusive como produto da vida moderna. Não é à toa que Libro Blanco (2007) assinala que as más formações congênitas, os acidentes (laborais, de trânsito, domésticos), as novas enfermidades que invalidam as pessoas, como a AIDS, e o próprio curso da idade, sob determinadas circunstâncias físicas e pessoais, são fatores que contribuem para que a dependência seja um problema social de primeira magnitude.

\footnotetext{
${ }^{3}$ Texto original: "La necesidad de ayuda o asistencia necesaria para realizar las actividades de la vida cotidiana", o, de manera más precisa, como "un estado en el que se encuentran las personas que por razones ligadas a la falta o la pérdida de autonomía física, psíquica o intelectual, tienen necesidad de asistencia y/o ayudas importantes a fin de realizar los actos corrientes de la vida diaria y, de modo particular, los referentes al cuidado personal".
} 
Até mesmo situações de dependência funcional que afetam as pessoas de idade avançada provêm de idades anteriores, como o caso de uma deficiência intelectual grave de nascimento ou derivada de um acidente de trabalho. Porém, a maior parte das situações de dependência aparece ou consolida-se no curso do envelhecimento em função de processos patológicos. Em tais casos, a dependência de ajuda para as atividades comuns não se vincula necessariamente ao envelhecimento comum e, sim, ao envelhecimento patológico (CASADO, 2006, p.15).

É esse quadro situacional que explica por que hoje, tanto na União Europeia e, particularmente, na Espanha, onde sempre houve a necessidade de cuidados nas situações de dependência, há aumento da preocupação com a relação entre dependência e cuidado. Esse fato está diretamente associado à dimensão da mudança provocada pelo envelhecimento populacional, que retira esse fenômeno da esfera individual e privada e transforma-o em assunto público. Isto é, em assunto que afeta a sociedade e exige a revisão dos objetivos dos cuidados e financiamentos por parte do Estado.

Daí a compreensão de que, na trajetória da luta pela garantia dos direitos humanos às pessoas idosas, existe uma complexidade que envolve o mercado, o Estado, a família e todo um processo histórico do Estado de bem-estar e as políticas públicas para o envelhecimento, o que será explicitado a seguir. 


\section{CAPITALISMO EM CRISE E POSSIBILIDADES DAS POLÍTICAS PÚBLICAS PARA O ENVELHECIMENTO: DESTAQUE À DEPENDÊNCIA E AO CUIDADO}

Compreender o fluxo do capitalismo, seus caminhos sinuosos e sua estranha lógica de comportamento é, portanto, fundamental para entendermos as condições em que vivemos.

David Harvey

\subsection{ASCENSÃO E CRISE DO ESTADO SOCIAL NO CAPITALISMO DOS ÚLTIMOS SETENTA ANOS}

O Estado Social ou de Bem-Estar (EBE) é, conforme Moreno, "un conjunto de instituciones estatales provedoras de políticas sociales dirigidas a la mejora de las condiciones de vida y a procurar la igualdad de oportunidad entre los ciudadanos" (MORENO, 2012, p. 17).

Sua aparição, como um fenômeno institucional e histórico distinto das diversas experiências de provisão social que Ihes antecederam, desde o século XIV, sob várias dominações, como a "Lei dos Pobres", ocorreu, mais precisamente, na Europa, após a Segunda Guerra Mundial. Mas isso não significa que esse Estado tenha, a partir de então, em todo lugar, um padrão unívoco e se manteve imune a variações.

Segundo Pereira (2008), um traço distintivo do Estado de Bem-Estar do segundo pósguerra, apontado por Misha, são as políticas de pleno emprego propiciadas pelo prevalecimento de um novo modelo socioeconômico, denominado "keynesiano", e de um novo regime de produção conhecido como "fordismo". Assim, ao lado de políticas sociais universais regidas pelo estatuto da cidadania e de ações de combate à pobreza, a intervenção estatal no sentido de manter o pleno emprego como motor do consumo e da produtividade econômica foi crucial para caracterizar o Estado de Bem-Estar pós-bélico e para diferenciá-lo de outras intervenções governamentais e da política social em seu sentido amplo.

Com efeito, embora o Estado Social se manifeste por meio de políticas igualmente sociais, estas têm suas particularidades. Conforme Moreno (2012), tais políticas:

[...] son intervenciones de los poderes públicos que afectan a las oportunidades vitales, sobre todo en los ámbitos de la educación, el empleo, la salud, la seguridad social y las transferencias fiscales (MORENO, 2012, p. 17).

Ou, nas palavras de Pereira (2008, p. 53), a política social, comparada ao Estado de Bem-Estar é "mais ampla, variável, complexa e longeva" (p. 53), (...) "apesar de os dois 
terem se encontrado e se imbricado num momento histórico específico (1945-1975) e de ter sido este o melhor momento da política social" (PEREIRA, 2008, p. 57).

De fato, o período compreendido entre 1945 e 1975 é amplamente reconhecido como a "idade de ouro" ou os "trinta anos gloriosos" do Estado de Bem-Estar, nos quais os cidadãos da Europa ocidental tiveram melhores condições de vida em relação à saúde, à educação, à previdência social, além de maiores facilidades de inserção num mercado de trabalho socialmente protegido. Esse Estado foi efetivo por garantir essas condições como direito de cidadania social e por manter a paz e a coesão social, embora tenha se questionado a sua capacidade de alterar a estrutura básica do capitalismo. Isso, sem falar da contradição por ele engendrada entre controle dos mecanismos de acumulação capitalista e legitimação do sistema, tão bem apontada pelos teóricos marxistas James O'Connor, lan Gough e Claus Offe, os quais, com suas formulações críticas, ensejaram a criação da "lenda O'Goffe", frequentemente citada na literatura da política social (MORENO, 2012; PEREIRA, 2008). De fato:

[...] un tanto paradójicamente, y desde posiciones ideológicas y prescriptivas de carácter contrapuesto, tanto pensadores neomarxistas como neoliberales y inspiradores de la Nueva Derecha coincidieron en las décadas de 1970 y 1980 en algunos de sus diagnósticos respecto a la dificultad de conciliar las lógicas del estado del bienestar y del crecimiento capitalista. Si bien la primera afectaba a una institución garante de estabilidad en el reparto desigual de la riqueza, la segunda encontraba dificultes en los mecanismos de generación de beneficios exigibles a la eficiencia capitalista (MORENO, 2012, p. 43).

Portanto, foi no bojo dessa contradição que o economista inglês Maynard Keynes mentor intelectual da teoria macroeconômica, que previa o intervencionismo estatal na economia por meio de medidas fiscais e monetárias, para mitigar os efeitos perversas dos ciclos econômicas - preocupou-se, segundo Behring e Boschetti (2011), com saídas democráticas da crise capitalista ocorrida nos anos 1930. Além disso, propugnou mudanças na relação do Estado com o sistema produtivo e rompimento parcial com os princípios do liberalismo. Para ele, a mão invisível do mercado era o caminho para o bem comum, mas o Estado deveria intervir para criar demanda efetiva, restabelecendo o equilíbrio econômico mediante política fiscal expansiva, mesmo sob o risco de déficit em períodos de crise.

Por seu turno, o industrial americano Henry Ford, patrocinador da técnica capitalista de linha de montagem de produção de massa, associou a geração da demanda ao estabelecimento de uma cultura de consumo também massiva, sem vinculação necessária com o Estado de Bem-Estar Social. E disso resultou que o acesso ampliado ao consumo, incentivado por Ford, contribuiu significativamente para o fortalecimento da demanda agregada, prevista por Keynes, redundando no crescimento econômico sustentado que criou a ilusão de que: 
[...] las desigualdades poseían un carácter circunstancial y que los diferentes niveles socioeconómicos serían una mera función relativa y los procesos de movilidad social - generalmente ascendente - de los ciudadanos. Rico y pobre, por consiguiente, serían etapas de un perpetuo móvil en función de las capacidades y deseos por mejorar o empeorar de los propios ciudadanos (MORENO, 2012, p. 47-48).

Entretanto, conforme Esping-Andersen (2011), a expansão do Estado de Bem-Estar começou a suscitar preocupações conservadoras com as consequências fiscais das provisões sociais públicas em meio a uma nova crise capitalista que se instalou no final dos anos 1970: uma crise de superprodução, comum ao capitalismo, que, ao não encontrar demanda correspondente, provocou consequências depressivas e recessivas, por muitos considerados, equivocadamente, como resultado das políticas do EBE. Tal crise, associada aos choques do petróleo dos anos 1973-1974 e 1978-1979, abalou os alicerces da prosperidade econômica da "idade de ouro" do Estado de Bem-Estar, fazendo-a ceder espaço a um período menos promissor, denominado por Moreno (2012) de "idade de prata". E, nesta fase, o EBE manteve apreciável resiliência, para usar a expressão de Taylor-Gooby (2003) diante dos constantes ajustes econômicos e cortes nos gastos sociais a que se viu submetido.

Segundo Rodriguez Cabrero (1997), a crise mais profunda do Estado de Bem -Estar do segundo pós-guerra começou no período de 1950-1980, ainda na época da prevalência do modelo keynesiano-fordista que coincidiu com a emergência de novas forças produtivas e tecnológicas. O esgotamento do EBE não foi só de natureza econômica, mas também organizativa, social, política e ideológica, causando o fim do pleno emprego, de mudanças de vida, do consumo e, acima de tudo, a crise de legitimidade.

Nesse período, ficou evidenciada a crescente influência do mercado sobre o EBE, o que repercutiu negativamente sobre os direitos sociais e as políticas sociais que deveriam concretizá-los. Esses direitos e políticas também sofreram forte impacto com o envelhecimento populacional, que elevou os gastos sociais e desafiou o Estado e a sociedade a repensarem as suas estratégias de ação social.

As transformações do fordismo em pós-fordismo movidas pelo imperativo de adaptação do capitalismo às economias globais levaram a União Europeia - UE a reestruturar o EBE e não eliminá-lo em virtude de vários motivos, inclusive estruturais: o capitalismo não vive sem Estado regulador. Mas, dentre esses motivos, vale ressaltar o envelhecimento populacional e os riscos políticos de desemprego estrutural que, na prática, limitavam a gestão governamental.

A primeira reestruturação do EBE coincidiu com o aumento do preço do petróleo, em 1973/1974; com o colapso do socialismo real no Leste europeu e com a queda do muro de 
Berlim, em 1989. Outra reestruturação ocorreu nos anos de 1990, com as privatizações e redução da proteção social, a mercantilização da proteção social, a crise fiscal do Estado e a fragmentação do mercado de trabalho, produzida pela gestão neoliberal da crise.

No ano de 1979, o Governo conservador da ex-Primeira Ministra inglesa Margareth Thatcher quebrou um amplo consenso econômico, político e social, sustentador do EBE britânico, fato que foi seguido por outros países europeus e do chamado Primeiro Mundo. Segundo Moreno (2012), esses países:

[...] retrotrajeron sus recetas de economía política a actuaciones "ortodoxas" propias de las formas del capitalismo decimonónico, tales como la reversión de la intervención pública (rolling back the frontiers of the state), una baja inflación, una férrea disciplina financiera y una neutralización de actores sociales antagónicos (sindicatos) (MORENO, 2012, p. 20).

Tal postura representou retrocessos no campo dos direitos sociais e (re) privatizações de empresas públicas, também no Brasil, em esforço ao credo neoliberal de transferir para os mercados financeiros a condução da vida econômica e social.

As orientações de cunho neoliberal monopolizaram os debates da economia política, angariando um acordo quase unânime que culminou, em 1989, com o Consenso de Washington, comandado pelo Banco Mundial, Fundo Monetário Internacional - FMI e Departamento do Tesouro Nacional dos Estados Unidos. O referido Consenso passou a funcionar como uma regra estabelecida para os países da OCDE, outorgando forças ao mercado como critério basilar e impondo, como referência, o padrão anglo-americano de globalização.

No entanto, para agravar ainda mais esse quadro de retrocessos sociais, desde 2008, o capitalismo vem enfrentando outro agudo momento de crise que, de acordo com Boschetti (2010), está produzindo efeitos amargos para as políticas sociais. Trata-se do que Moreno (2012) identificou como a "idade de bronze" do Estado de Bem-Estar, iniciada oficialmente em 2008, com a "bancarrota [do Banco] Lehman Brothers, a venda do Merryll Lynch al Bank of America e o colapso do gigante dos seguros American International Group" (p.215/16; tradução nossa); mas, que, na prática, expressou-se, em 2007, com o crack econômico estadunidense causada pela quebra das hipotecas imobiliárias subprime e a queda da bolsa de Nova York. Trata-se de uma crise que, embora tenha se explicitado nos Estados Unidos, é, como diz Mészáros (2009), estrutural, isto é, global (abarcando todos os países, incluindo o Brasil); sistêmica (atingindo todas as áreas da existência humana) e permanente (não mais cíclica e temporária). Diante dessa crise, países europeus como a Grécia, Espanha, Portugal e Itália foram obrigados a equilibrar suas contas, efetuar cortes nas aposentadorias e pensões, levando pessoas idosas ao suicídio. Instalou-se, a partir de então, no dizer de 
Moreno (2012), a combinação dos discursos e das práticas neoliberais e neoconservadores, formando uma espécie de pensamento único que propugna:

(1) una profundización del proceso de desreglamentación, flexibilización y liberación, no solo respecto a las políticas estatales, sino también en lo concerniente a aquellas funciones estatales clásicas como las relativas al planeamiento y provisión de servicios públicos y sociales;

(2) un apoyo activo desde las propias instancias gubernamentales a los procesos de internacionalización de los mercados, a la promoción de un individualismo consumista y expresivo, y la creciente mercantilización de la vida pública (MORENO, 2012, p. 87-88).

Assim, com a crise de 2007/8, o modelo socioeconômico neoliberal vem, segundo Moreno (2012), se constituindo no principal responsável pelas turbulências econômicas mundiais, "advogam pela privatização [da previdência] enquanto os sindicatos e os lobbies dos aposentados insistem na preservação do status quo a todo custo. Duas posições que não são nem realistas nem equitativas" (ESPING-ANDERSEN, 2011, p. 101). E pregam não mais um Estado Social - visto que este se tornou "asocial", na percepção de Moreno (2012), ou antissocial, na de Pereira (2009) - mais um capitalismo de bem-estar em que o indivíduo é responsável pelo seu bem-estar. Essa postura é criticada por Moreno nos seguintes termos:

\begin{abstract}
Las sociedades modernas otorgaron carta de naturaleza al mercado y al estado como instituciones reguladoras del bienestar y de la satisfacción vital de los ciudadanos. La primera institución articula los valores del auto interés individualista y del cálculo económico en las relaciones materiales entre los ciudadanos. La segunda es depositaria de la autoridad de carácter coercitivo, asumiendo funciones de procura pública. Tanto una como otra han contribuido a disipar las responsabilidades morales de los ciudadanos respecto al cuerpo político, o politeya, del que forma parte. El sentido de obligación moral de los individuos respecto a sus conciudadanos han tendido a debilitarse, bien se pusiese el acento en la mercantilización o en la solidaridad vicaria estatalista. Tales desarrollo han socavado en diferentes grados e intensidades el proprio concepto de bienestar social y han contribuido a difundir la idea de que el EB europeo es un mero epifenómeno de la modernidad (MORENO, 2012, p. 40).
\end{abstract}

Dessa forma, a ação do Estado (neo)liberal torna-se residual e reduz-se a atendimentos sociais que apenas aliviam a situação de pobreza, tendo ainda como critério de elegibilidade para o acesso a esse atendimento o mérito e não, necessariamente, a justiça social.

Para tanto, o Estado de Bem-Estar tornou-se menor, controlado pelo grande capital e pelas multinacionais, sendo privilegiadas as políticas sociais mínimas. Dessa maneira, passou a ser atribuída ao cidadão a responsabilidade pelos seus próprios riscos, vez que apenas eles sabem de suas necessidades e de seus interesses. Surgem, assim, as incertezas e os riscos sociais com a racionalização dos sistemas de proteção social gerados pelas pressões neoliberais da globalização. 
Nessa conjuntura, a dependência e os cuidados são considerados como riscos sociais que demandam atenção de alto custo e estão inseridos no quarto pilar do EBE, que são os serviços sociais, aos quais competem medidas e salvaguardas e que contribuem para a coesão social, como participação e inclusão social dos cidadãos, redes de serviços estruturadas e direitos sociais assegurados. Com a crise estrutural do capital em curso, as políticas públicas destinadas às pessoas idosas, em situação de dependência, estão sendo amplamente afetadas com a limitação de serviços imposta pelas políticas de austeridade econômica prevalecente, que preconizam restrições orçamentárias e respondem por um EBE empobrecido e agudizante.

Apesar de, em boa parte dos países europeus, já estar consolidado o desenvolvimento de políticas de apoio a dependência, para Rodriguez Cabrero (2014), manter os atuais sistemas sob a perspectiva da universalidade, qualidade e sustentabilidade não quer dizer que não possa haver reformas no sentido de reduzir a intensidade protetora do Estado, retornando às famílias parte da carga dos cuidados públicos. Com o envelhecimento populacional, a pressão da economia de mercado aumenta para conter os gastos públicos e dividir as despesas com o usuário e sua família.

Como já citada, a dependência é um risco social. Mas, por quê? Porque ela corresponde à noção corrente de risco que está relacionada às limitações da proteção social frente aos acontecimentos cujos efeitos provocam mudanças societárias desafiadoras das política públicas (MORENO, 2012). O aumento da expectativa de vida é um desses acontecimentos que, não obstante salutar, cria o seguinte dilema nas sociedades capitalistas: amplia significativamente o leque de dependência nas pessoas acima de 80 anos de idade, o que tem implicado maiores demandas por serviços sociais onerosos; mas dado a crise capitalista em curso e o imperativo do sistema de adotar uma férrea disciplina financeira no campo social, a capacidade protetora do Estado vem-se reduzindo cada vez mais, dando lugar à mercadorização dos serviços e à socialização dos cuidados de idosos dependentes entre Estado, família e mercado. Daí, o dilema das políticas públicas em tempos de austeridade.

A contenção de gastos, em decorrência da crise, deixa as pessoas em situação de dependência, em estado de vulnerabilidade. A Lei da dependência encontra-se sob um fogo cruzado: por um lado, tem que propiciar os cuidados de longa duração e, por outro, frear os gastos. Portanto, eis a questão a ser retomada nos próximos itens deste capítulo: como avançar na melhoria e na ampliação dos cuidados se, a cada dia, aumenta o número de pessoas com dependência? E, ainda, se a ausência de programas e serviços de prevenção à dependência e à estimulação da autonomia vem contribuindo para o agravamento da dependência. 


\subsection{O SISTEMA DE ASSISTÊNCIA À PESSOA IDOSA DEPENDENTE NA CONJUNTURA DA CRISE ECONÔMICA CAPITALISTA}

Considerando a história recente do Estado de Bem-Estar dos países europeus desenvolvidos, Rodriguez Cabrero (2011) constatou que o risco da dependência suscitava uma combinação de intervenção prioritária, por parte da família, e secundária, por parte das instituições públicas. Na família, a mulher era encarregada do cuidado das crianças e das pessoas dependentes. O Estado intervia mediante ajudas financeiras e técnicas em caso de acidentes do trabalho, que provocavam invalidez grave e, excepcionalmente, atendia as pessoas em situação de dependência sem recursos e sem apoio familiar. Os cuidados de longa duração eram realizados pela família, porém sem remuneração. O Estado cumpria uma função residual e as sociedades civis sem fins lucrativos desenvolviam ações assistenciais voltadas para as pessoas sem condições financeiras.

Essas mudanças no papel do Estado Social traz à tona a reflexão sobre "regimes de bem-estar", que será aqui brevemente comentada a título de informação. Na Europa, segundo Moreno (2012), existem quatro regimes de bem-estar social: o Anglo-saxão, cujo maior exemplo é a Grã Bretanha; o Continental, abarcando os países da Europa Continental; o Nórdico, representando os países escandinavos; e o Mediterrâneo, do qual fazem parte a Espanha, sul da Itália, Portugal e Grécia. Essa classificação (dentre outras), na verdade, engloba outros países fora do continente europeu e "há sido el más influyente en el análisis de la configuración de los estado del bienestar. Tal perspectiva propone el agrupamiento de países caracterizados por una peculiar constelación de encajes económicos, políticos y sociales" (MORENO, 2012, p. 53). Regimes, portanto, remetem a categorias que contemplam famílias de nações com características comuns quanto à proteção social, particularmente no que concerne à estruturação de cada família de acordo com princípios organizativos, ideologias e aspectos culturais afins.

O Estado Social ou EBE de cada país se adaptará aos regimes que Ihes são correspondentes. Em torno dessa ideia, o dinamarquês Esping-Andersen, seguindo o pensador inglês dos anos de 1960, Richard Titmuss, construiu, nos anos 1990, uma tipologia de regimes de bem-estar que vem inspirando os estudiosos da política social contemporânea. Para ele, coexistem contemporaneamente, embora não de forma pura, três grandes grupos de regimes de bem-estar: o Liberal, que corresponde ao anglo-saxão de Moreno (centrado no empoderamento dos indivíduos e na maior participação do mercado e da família, do qual o ícone são os Estados Unidos); o Conservador (cujas marcas são o conservadorismo e o apego às tradições, como nas nações católicas e regimes ditatoriais); o Social-democrata, ou nórdico na concepção de Moreno (ancorado na maior participação do Estado na distribuição universalista da proteção social). Quanto ao regime mediterrâneo, 
este foi acrescentado pelos estudiosos do sul da Europa para destacar as particularidades "latinas" da proteção social no velho continente.

Trazendo essa tipologia para âmbito dos cuidados dos idosos dependentes em um momento histórico de prevalecimento dos ditames neoliberais, tem-se que o regime nódico, de acordo com Rodriguez Cabrero (2011), tornou-se pioneiro no desenvolvimento de um sistema público de serviços sociais que, a partir da década de 1960, foi substituindo em seus quadros de cuidadores as mulheres à medida que estas aumentavam a sua participação no mercado de trabalho. Nesse regime de bem-estar, comparado aos demais, existe ainda um elevado nível de coordenação da assistência social e da saúde, os serviços são integrados, contribuindo para não sobrecarregar a área de saúde, a qual é mais onerosa. O regime continental dá proteção em caso de invalidez no âmbito da Previdência Social à família cuidadora. O mediterrâneo, até recentemente, seguiu ancorado no modelo de cuidados familiares sólidos com apoio residuais de um sistema de serviço social pouco desenvolvido. E o regime liberal combina responsabilidades individuais com apoio crescente por parte dos serviços sociais de natureza assistencial. Sobre as mudanças verificadas nos regimes de bem-estar existentes, Rodriguez Cabrero afirma que:

[...] a atenção à dependência ou cuidados de longa duração passou para o primeiro plano das reformas em matéria de política social em uma parte importante do Estado de Bem-estar no contexto de contenção e reestruturação profunda (1990-2007) e, nos últimos quatro anos, de corte e transferência do custo às pessoas afetadas e às famílias (e dentro destas, novamente às mulheres) (RODRIGUEZ CABRERO, 2013, p. 237, tradução nossa). ${ }^{4}$

Particularmente, o sistema espanhol retrata as mazelas do regime mediterrâneo, no qual a coordenação de assistência social e de saúde é precária e desigual. Além disso, a crise estrutural do capital já mencionada teve impacto regressivo, freando o desenvolvimento na implementação dos cuidados de longa duração às pessoas em situação de dependência. A título de ilustração, oferecem-se, a seguir, os quadros preparados por Rodriguez Cabrero a respeito das reformas referentes aos serviços de cuidados de longa duração levadas a cabo pelos diferentes modelos de bem-estar europeus nos períodos de 1980-2000 e de 2000-2010.

\footnotetext{
${ }^{4}$ Texto original: La atención a las situaciones de dependencia o cuidado de larga duración (CLD) (Long-term care o LTC en terminología académica y profesional) ha pasado al primer plano de las reformas en materia de política social en una parte importante de los Estados de Bienestar en un contexto de contención y restructuración profunda (1990-2007) y, en los últimos cuatro años, de recorte en las prestaciones y desplazamiento del coste a las personas afectadas y las familias (y dentro de éstas nuevamente hacia las mujeres).
} 


\begin{tabular}{|c|c|c|c|c|}
\hline $\begin{array}{l}\text { Reformas del } \\
\text { período } \\
\qquad 1980-2000\end{array}$ & $\begin{array}{c}\text { Modelo } \\
\text { anglosajón } \\
\text { (Reino Unido e } \\
\text { Irlanda) }\end{array}$ & $\begin{array}{c}\text { Modelo } \\
\text { continental } \\
\text { (Alemanha, } \\
\text { Francia, Austria, } \\
\text { Holanda, } \\
\text { Luxemburgo e } \\
\text { Bélgica }\end{array}$ & $\begin{array}{l}\text { Modelo nódico } \\
\text { (Suecia, Filandia, } \\
\text { Dinamarca) }\end{array}$ & $\begin{array}{c}\text { Modelo mediterrâneo } \\
\text { (Espanha, Italia, } \\
\text { Portugal) }\end{array}$ \\
\hline $\begin{array}{l}\text { Derecho Social a } \\
\text { la protección } \\
\text { social de la } \\
\text { dependencia }\end{array}$ & $\begin{array}{l}\text { Derecho } \\
\text { mixto:universal en } \\
\text { atención sanitaria } \\
\text { y protección } \\
\text { asistencial en } \\
\text { servicios sociales }\end{array}$ & $\begin{array}{l}\text { Derecho universal } \\
\text { com niveles: } \\
\text { contributivo y no } \\
\text { contributivo }\end{array}$ & Derecho Universal & $\begin{array}{l}\text { Derecho } \\
\text { mixto:universal en } \\
\text { atención } \\
\text { sanitaria;asistencial en } \\
\text { servicios sociales. }\end{array}$ \\
\hline Financiación & $\begin{array}{l}\text { Impuestos y } \\
\text { copago en servicio } \\
\text { sociales para los } \\
\text { que exceden un } \\
\text { nivel de renta. }\end{array}$ & $\begin{array}{l}\text { Cotizaciones en } \\
\text { nivel contributivo: } \\
\text { impuestos en el } \\
\text { nivel no } \\
\text { contributivo; } \\
\text { copago en las } \\
\text { prestaciones de } \\
\text { servicios. }\end{array}$ & $\begin{array}{l}\text { Impuestos } \\
\text { generales y } \\
\text { locales; copago. }\end{array}$ & $\begin{array}{l}\text { Impuestos generales, } \\
\text { cotizaciones y copago } \\
\text { para los que exceden } \\
\text { un nivel de renta. }\end{array}$ \\
\hline $\begin{array}{l}\text { Prestaciones } \\
\text { sociales }\end{array}$ & $\begin{array}{l}\text { Servicios y ayudas } \\
\text { monetarias.Ayuda } \\
\text { s técnicas }\end{array}$ & $\begin{array}{l}\text { Servicios y } \\
\text { prestaciones } \\
\text { monetarias } \\
\text { topadas. Ayudas } \\
\text { técnicas. }\end{array}$ & $\begin{array}{l}\text { Servicios sociales } \\
\text { y ayudas técnicas. }\end{array}$ & $\begin{array}{l}\text { Prestaciones } \\
\text { monetarias, servicios } \\
\text { sociales y ayudas } \\
\text { técnicas. }\end{array}$ \\
\hline $\begin{array}{l}\text { Responsabilidad } \\
\text { de organización y } \\
\text { gestión. }\end{array}$ & Municipal. & $\begin{array}{l}\text { Seguridad social, } \\
\text { Regiones y } \\
\text { Municipios. }\end{array}$ & $\begin{array}{l}\text { Municipal.Regiona } \\
\text { I y Municipal. }\end{array}$ & \\
\hline $\begin{array}{l}\text { Provisión de } \\
\text { servicios según } \\
\text { importancia. }\end{array}$ & $\begin{array}{l}\text { Empresas, ONG y } \\
\text { ayuntamientos. }\end{array}$ & $\begin{array}{l}\text { ONG, empresas, } \\
\text { papel residual de } \\
\text { los ayuntamientos } \\
\text { em modelo } \\
\text { alemán. }\end{array}$ & $\begin{array}{l}\text { Ayuntamientos y } \\
\text { crecente } \\
\text { importancia de } \\
\text { empresas. }\end{array}$ & $\begin{array}{l}\text { Ayuntamientos, ONG y } \\
\text { creciente importancia } \\
\text { de empresas. }\end{array}$ \\
\hline $\begin{array}{l}\text { Políticas de apoyo } \\
\text { al cuidado } \\
\text { informal. }\end{array}$ & $\begin{array}{l}\text { Apoyo limitado al } \\
\text { cuidador y } \\
\text { elevada } \\
\text { responsabilidad } \\
\text { individual. }\end{array}$ & $\begin{array}{l}\text { Amplio apoyo al } \\
\text { cuidador informal. }\end{array}$ & $\begin{array}{l}\text { Apoya y sustituye } \\
\text { a la familia } \\
\text { cuidadora. }\end{array}$ & $\begin{array}{l}\text { Limitado apoyo al } \\
\text { cuidador informal. }\end{array}$ \\
\hline $\begin{array}{l}\text { Situación sobre } \\
\text { los modelos. }\end{array}$ & $\begin{array}{l}\text { Debate político } \\
\text { sobre la } \\
\text { oportunidad de la } \\
\text { universalización } \\
\text { de la protección } \\
\text { social. }\end{array}$ & $\begin{array}{l}\text { Reformas en } \\
\text { Alemania } \\
\text { en } 2007 \text { para } \\
\text { lograr nuevos } \\
\text { equilibrios } \\
\text { institucionales y } \\
\text { financieros del } \\
\text { modelo. Reformas } \\
\text { previstas en } \\
\text { Holanda. }\end{array}$ & $\begin{array}{l}\text { Incremento de la } \\
\text { prestación de } \\
\text { servicio por parte } \\
\text { de las empresas } \\
\text { privadas en } \\
\text { Suecia y, en } \\
\text { general, en los } \\
\text { países nórdicos. }\end{array}$ & $\begin{array}{l}\text { Aprobación de la Ley } \\
\text { de la dependencia en } \\
\text { España. Libro Blanco } \\
\text { de la dependencia en } \\
\text { Italia. }\end{array}$ \\
\hline
\end{tabular}

Quadro 1 - Modelos europeus de cuidados de larga duración

Fonte: Rodriguez Cabrero (2014, p. 55) com base a: Gledinning (2007); Huber(2009); Pommer,

Weittiez y Stevens (2007); OCDE (2005). 


\begin{tabular}{|c|c|c|c|c|}
\hline $\begin{array}{l}\text { Reformas 2000- } \\
2010\end{array}$ & $\begin{array}{c}\text { Modelo } \\
\text { anglosajón } \\
\text { (Reino Unido e } \\
\text { Irlanda) }\end{array}$ & $\begin{array}{c}\text { Modelo } \\
\text { continental } \\
\text { (Alemania, } \\
\text { Francia, } \\
\text { Austria, } \\
\text { Holanda, } \\
\text { Luxemburgo, } \\
\text { Belgica) }\end{array}$ & $\begin{array}{c}\text { Modelo nódico } \\
\text { (Suecia, } \\
\text { Filandia, } \\
\text { Dinamarca) }\end{array}$ & $\begin{array}{c}\text { Modelo mediterrâneo } \\
\text { (Espanha, Italia, } \\
\text { Portugal) }\end{array}$ \\
\hline $\begin{array}{l}\text { Principios } \\
\text { orientadores }\end{array}$ & $\begin{array}{l}\text { Consumerismo } \\
\text { individualización } \\
\text { del riesco }\end{array}$ & $\begin{array}{l}\text { Refamiliarizació } \\
n y \\
\text { mercantilización }\end{array}$ & $\begin{array}{l}\text { Universalización } \\
\text {, familiarización } \\
y \\
\text { mercantilización } \\
\text { dual. }\end{array}$ & $\begin{array}{l}\text { Universalismo, } \\
\text { familiarización y } \\
\text { mercantilización. }\end{array}$ \\
\hline Accesibilidad & $\begin{array}{l}\text { Preferencia:pers } \\
\text { onas en grave } \\
\text { dependencia sin } \\
\text { recursos. }\end{array}$ & Universal. & Universal. & $\begin{array}{l}\text { Transición hacia } \\
\text { cobertura universal. }\end{array}$ \\
\hline Prestaciones & $\begin{array}{l}\text { Preferencias: } \\
\text { prestaciones } \\
\text { monetarias y } \\
\text { presupuesto } \\
\text { personal. }\end{array}$ & $\begin{array}{l}\text { Preferencia: } \\
\text { prestaciones } \\
\text { monetarias y } \\
\text { programas } \\
\text { conciliación. }\end{array}$ & $\begin{array}{l}\text { Servicios:crecimi } \\
\text { ento } \\
\text { prestaciones } \\
\text { monetarias y } \\
\text { presupuesto } \\
\text { personal. }\end{array}$ & $\begin{array}{l}\text { Preferencia: } \\
\text { prestaciones } \\
\text { monetarias; servicios } \\
\text { sociales municipales y } \\
\text { regionales. }\end{array}$ \\
\hline Provisión & $\begin{array}{l}\text { Privada } \\
\text { mercantil. }\end{array}$ & $\begin{array}{l}\text { Privada:mercanti } \\
\text { l;tercer sector en } \\
\text { declive. }\end{array}$ & $\begin{array}{l}\text { Pública con } \\
\text { crecimiento } \\
\text { sector mercantil. }\end{array}$ & $\begin{array}{l}\text { Mixta: provisión tercer } \\
\text { sector y crecimiento } \\
\text { sector mercantil. }\end{array}$ \\
\hline Financiación & $\begin{array}{l}\text { Mixta: pública y } \\
\text { copago. }\end{array}$ & $\begin{array}{l}\text { Mixta:impuestos, } \\
\text { cotizaciones y } \\
\text { copago. }\end{array}$ & $\begin{array}{l}\text { Pública y } \\
\text { copago. }\end{array}$ & $\begin{array}{l}\text { Mixtas: impuestos y } \\
\text { copago. También } \\
\text { cotizaciones. }\end{array}$ \\
\hline
\end{tabular}

Quadro 1 (continuação) - Modelos europeus de cuidados de larga duración Fonte: Rodriguez Cabrero (2014, p. 55) com base a: Gledinning (2007); Huber (2009); Pommer, Weittiez y Stevens (2007); OCDE (2005).

Em decorrência da crise e da reestruturação do Estado de bem-estar do segundo pósguerra, algumas medidas foram tomadas em relação à lei da dependência:

Em 2011, foi aprovado um decreto alterando o instrumental de avaliação "baremo" de dependência, dando o prazo de um ano para entrar em vigor a fim de permitir às Comunidades Autônomas e aos profissionais adaptação ao novo instrumento.

Em 12 de julho de 2012, o governo editou o Real-Decreto-Ley ํㅡㄹ, tomando medidas para garantir a estabilidade econômica e o fomento à competitividade da Lei da Dependência, destacando-se :

- Nova classificação da dependência em apenas três graus: grau III - grande dependência; grau II - dependência severa e grau I - dependência moderada;

- Melhoras na gestão; 
- Medidas para melhorar a capacidade de análise do SAAD - Sistema para Autonomia e Atenção à Dependência, com exploração estatística de dados do SISAAD;

- Criação do Conselho Territorial de Serviços Sociais e do Sistema para a Autonomia e Atenção à Dependência - SAAD;

- Medidas de poupança e redução do déficit público, reduzindo as horas de cuidados;

- Nova regulamentação de copago-ajuda financeira.

Houve também grandes reduções nos valores concedidos aos serviços prestados após aprovação do Real Decreto, que, conforme Prieto (2012), conseguiu poupar $€ 1.600$ milhões $(0,14 \%$ do PIB a preços de mercado de 2011). Os cortes efetuados alcançaram os seguinte montantes e distribuição: $21,24 \%$ na supressão do convênio dos cuidadores profissionais, 18,92\% com a redução dos valores pagos aos antigos beneficiários de prestação de cuidados no entorno familiar; $13,59 \%$ na redução a um nível mínimo da Administração Geral do Estado; 45,18\% nos serviços de atenção domiciliar e 1,08\% com a diminuição dos valores da prestação econômica para novos beneficiários (PRIETO, 2012, p. 48). Esses dados demonstram uma redução significativa dos recursos para os cuidados de longa duração.

O Real Decreto $\mathrm{n}^{0}$ 1.051/2013, de 27 de dezembro, unificou todas as normas relativas a prestações e serviços da Lei da Dependência, produzindo modificações na intensidade dos serviços e das prestações econômicas. Procedeu também modificação da classificação da situação da dependência e transparência no sistema de gestão. No entanto, tais modificações foram orientadas para diminuir valores nas prestações, tendo que seguir recomendações da União Europeia de cortar gastos.

A lei estabelece critérios que dão prioridade a pessoas com dependência grave. As comunidades autônomas estão cientes dos acordos do Conselho Territorial (nacional), segundo os quais, a partir da aprovação do real decreto de nível mínimo, não se transferirá dinheiro dos recursos gerais do Estado para cofinanciar a atenção à dependência de nível mínimo. Também foi acordado que as comunidades autônomas devem priorizar as prestações de serviços que recebem provisões econômicas por cuidados no entorno familiar. Além disso, para o cálculo do valor da contribuição financeira por parte do usuário, são levados em consideração a sua renda e o patrimônio, o que, conforme Rodriguez Cabrero (2007), poderá levar à expulsão da classe média e desincentivo à poupança. Esse é um problema a ser considerado. 
No entanto, ainda de acordo com Rodriguez Cabrero (2007, p. 82), as pessoas que estão abaixo da linha de pobreza são excluídas da contribuição financeira, assim como boa parte das pessoas cuja renda não chega a $€ 7.000$ anuais. Assim, a contribuição do usuário não tem um peso relevante no financiamento do sistema e, em consequência, o gasto assistencial terá que ser incrementado para complementar o custo do serviço, gasto esse que deverá ser assumido pelas Administrações Territoriais.

O custo total de atenção à dependência foi estimado, para 2013, em $€ 6.509$ milhões, o que supõe um gasto médio de $€ 8.695$ por beneficiário. A atenção residencial é o serviço com maior custo: $€ 2.919$ milhões, correspondendo a 44,84\% do custo total. Em seguida, vem ajuda a domicílio com $12,14 \%$ do custo total. As prestações econômicas equivalem a $50,71 \%$ do atendimento e têm um custo de 31,35\% do total (MORAGA y GONZÁLES, 2014, p. 83, tradução nossa) $)^{5}$.

Diante desse cenário, fica evidente a tendência de aumentar as prestações econômicas diante da facilidade de conceder a ajuda sem intermediários, a baixo custo, enquanto a institucionalização em residências (ILPI) consome quase a metade dos recursos disponibilizados para atenção à dependência.

$\mathrm{Na}$ Espanha, com a alta taxa do envelhecimento populacional, já existem várias experiências relacionadas aos serviços de atenção às pessoas idosas. Nas Comunidades Autônomas, começaram, em 1985, serviços como o SAD - Serviço de Ajuda Domiciliar, destinados às pessoas com dependência, principalmente as moderadas. Uma década depois (1985-1995), o cenário mudou com o aumento das pessoas com idade acima dos 80 anos e com problemas cognitivos, alterando-se também o perfil das famílias que tinham a mulher como cuidadora. Nesse contexto, até os profissionais mudaram a sua visão em relação aos cuidados das pessoas idosas dependentes, observando que necessitavam de um suporte maior, tanto no âmbito institucional quanto comunitário.

A dependência requer um trato especial, sendo este um dos grandes desafios para a política social. No entanto, a demanda por serviços é crescente e vem coincidindo com a crise do sistema de apoio informal, além dos cortes nos gastos sociais em decorrência da crise capitalista.

\footnotetext{
${ }^{5}$ Texto original: El coste total anual de la atención a la dependencia estimado para el año 2013 asciende a 6.509 millones de euros, lo que supone un coste medio anual por beneficiario de 8.695 euros. La atención mediante servicios supone el $68,65 \%$ del coste total a pesar de representar el $49,29 \%$ del total de prestaciones. En especial la atención residencial es el servicio que tiene asociado un mayor coste con 2.919 millones de euros, un $44,84 \%$ del coste total, seguido de la ayuda a domicilio con un $12,14 \%$ del coste total.

En cuanto a las prestaciones económicas, que son el $50,71 \%$ de las prestaciones, su coste solo es el $31,35 \%$ del coste total.
} 
De acordo com as projeções demográficas contidas no Libro Blanco (2005), havia, em 2011, na Espanha, 8.084.582 pessoas com 65 anos e mais de idade, o que correspondia a 17,6\% da população. Porém, em 2016, esse mesmo País terá 8.857.956 pessoas nessa faixa etária, equivalendo a $18,5 \%$ da população total. Todavia, como a população que mais cresce é a que está acima dos 80 anos, a previsão para 2016 é a de que essa faixa supere 2,9 milhões de pessoas. Assim, 3 de cada 10 idosos acima de 65 anos ultrapassarão os 80 anos, sendo este o grupo que mais estará submetido à situação de dependência; e mais, a dependência tornar-se-á um desafio para as políticas públicas.

Dada essa realidade e considerando-se o clima de austeridade econômica que se abate sobre as políticas de proteção social pública em escala mundial, a rede de serviços assistencial será insuficiente. Em contrapartida, haverá grande pressão sobre o sistema de cuidados, em demanda de uma infraestrutura adequada com equipamentos, recursos técnicos, humanos e financeiros condignos. De acordo com os dados do Instituto de Mayores y Servicio Social - IMSERSO (2014), em janeiro de 2012, estavam, na lista de espera para conseguir prestação de serviço dentro do modelo da dependência, 305.941 pessoas; e, em março de 2014, essa cifra situava-se perto de 186.138 pessoas, havendo uma redução de 39,16\% - o número mais baixo desde a implantação da lei da dependência. As pessoas com dependência moderada tinham acesso aos serviços, mas, a partir da crise financeira agudizada em 2008, houve alterações na lei e, atualmente, só são atendidas as pessoas com dependência grave.

Desde então, para ingressar em uma instituição de longa permanência, a lista de espera é tão grande que chega a durar 4 anos e, em um centro dia, 2 anos. Conforme informações concedidas por um coordenador técnico de uma instituição, a lista de espera está longe de ser reduzida, pois a demanda por serviços para as pessoas idosas dependentes continua aumentando.

Outro fato decorrente da crise financeira é o de várias pessoas idosas, que estavam institucionalizadas ou sendo assistidas em um centro dia, estarem sendo levadas para casa pelos seus familiares pois, em razão do desemprego, parte da pensão que era utilizada para pagar a instituição passa a subsidiar a manutenção da família.

\subsection{O ESTADO E CUIDADOS DE LONGA DURAÇÃO}

De maneira geral, na "idade de ouro" do Estado de Bem-estar, os cuidados de longa duração dispensados aos idosos nos países capitalistas centrais eram tratados como um "risco familiar", existindo poucas medidas estatais dispensadas às famílias, a não ser no caso dos acidentes de trabalho graves. 
No final da década de 1970 e início dos anos 80, com a transição demográfica, a situação começou a mudar e entrou na agenda política o tema da dependência. Nos fins dos anos 1980 e início dos 90, quando o "risco familiar" começou a transbordar a capacidade das famílias de enfrentá-lo, surgiram as primeiras leis de dependência como resposta institucional a essa realidade. A esse respeito, Rodriguez Cabrero afirma que:

[...] es preciso considerar que la respuesta institucional al risco sucede en un momento histórico en el que tiene lugar un cambio profundo o crisis en la naturaleza y modos de intervención del Estado de Bienestar lo que contribuirá a que progresivamente la respuesta al risco de dependencia redefina los papeles tradicionales del Estado, el mercado, la familia y la sociedad civil bajo nuevos clusters sócio-institucionales en los que el papel del Estado se acrecienta, se expande la oferta mercantil, se reestructura la atención familiar en el seno de los hogares y la sociedad organizada afianza su función colaboradora del Estado (RODRIGUEZ CABRERO, 2011, p. 68).

O cenário atual da idade de bronze do EBE deixa evidente o processo de mudança na proteção social e da dependência como risco social que vem aumentando com o envelhecimento populacional e deixando de ser responsabilidade familiar. Assim, em 2003, a Comissão Europeia definiu a importância de se garantir sistemas universais de dependência, com atenção à saúde e inclusão do sistema de pensões.

Quanto ao sistema de pensões, Esping-Andersen (2011) pondera que as reformas desse sistema converteram-se em tema-chave de debates políticos. Mas, para serem legítimas, afirma, tais reformas devem se pautar, prioritariamente, pelos princípios de justiça social. Contudo, avalia o autor, a referida justiça se torna muito mais espinhosa a partir do momento em que se constata que "a morte não é democrática": "os ricos vivem mais tempo que os pobres, o que gera imensas desigualdades entre aposentados de uma mesma geração"6 (ESPING-ANDERSEN, 2011, p. 101; tradução nossa). Além disso, com o aumento dos aposentados, a sociedade deve se preparar para um incremento da demanda por cuidados aos idosos dependentes, não só por causa do seu rápido e progressivo aumento, mas porque a reserva tradicional dos cuidadores informais saiu da família e está desaparecendo (ESPING-ANDERSEN, 2011, p. 103).

O difícil, portanto, conclui Esping-Andersen, é realizar a equidade em uma realidade em que os ricos estão cada dia mais ricos e os pobres, mais pobres, enfrentando as dificuldades decorrentes do envelhecimento com poucos recursos e da ausência de serviços capazes de lhes propiciar melhor qualidade de vida, em especial os idosos que apresentam dependência.

Diante dessa tendência, as estratégias europeias de proteção e de inclusão social integram os eixos da inclusão social, da sustentabilidade do sistema de pensões e da

\footnotetext{
${ }^{6}$ Texto original: "la muerte no es democrática": los ricos viven más tiempo que los pobres, cosa que ocasiona inmensas desigualdades entre jubilados de una misma generación.
} 
coordenação, e da sustentabilidade dos sistemas de saúde e atenção à dependência, estabelecendo-se uma inter-relação de governança e de apoio baseado na cooperação e na coordenação de qualidade (RODRIGUEZ CABRERO, 2011, p. 68).

O aumento da expectativa de vida é, como já salientado, uma grande conquista da humanidade e, como tal, não deve ser encarado como um risco social. Este é a dependência que vem sendo incrementada na faixa populacional com idade acima dos 80 anos, devido às incapacidades apresentadas por essa população para realizar atividades de vida diária - AVDs, em decorrência de demência e de outras restrições. Por isso, deve-se ter em mente o aumento da dependência associada às enfermidades mentais, laborais e os acidentes de trânsito e não na longevidade em si.

Com a saída da mulher para o mercado de trabalho, uma grande demanda social de cuidados voltados para idosos se verificou na Europa, exigindo-se a redefinição da estrutura de ofertas dos cuidados. Assim, as organizações voluntárias de mulheres, associações de pessoas afetadas e familiares têm sido agentes-chaves para inserção da dependência na agenda política. Inicialmente, as organizações não governamentais sem fins lucrativos cobriram a demanda de cuidados e atenção às pessoas dependentes, mas a magnitude dessa demanda passou a requerer maior engajamento das administrações públicas.

A política de cuidados na Europa faz parte das estratégias de proteção social e de inclusão, além do Método Aberto de Coordenação - o MAC Social - que vem estimulando a difusão das melhores práticas institucionais sobre autonomia e dependência, cobertura de novos sistemas com ajudas financeiras e serviços. Isso, sem abordar a avaliação do sistema visando à qualidade dos serviços destinados às pessoas idosas em situação de dependência. Mas, não obstante, vale salientar que não houve retrocesso em nenhum país da União Europeia no que se refere à função familiar do cuidado que sobrecarrega famílias cuja estruturação foge ao padrão tradicional.

O modelo social europeu de cuidados de longa duração é caracterizado, de acordo com Rodriguez Cabrero, da seguinte maneira:

[...] Permanencia y refuerzo de la familia; extensión de la responsabilidad del Estado en cuanto a cobertura, financiación y coordinación del sistema de atención bajo la forma de descentralización y nexos variables de colaboración con el sistema sanitario; consolidación selectiva del Tercer Sector como prestador de servicios en colaboración con el Estado a la vez defensor de derechos de los colectivos más vulnerables; y avance de la esfera mercantil como oferta propia mediante seguros complementarios de dependencia y como prestador de servicios públicos en competencia con el Tercer Sector (RODRIGUEZ CABRERO, 2011, p. 71).

Portanto, cabe frisar que os sistemas de atenção à dependência da União Europeia não substituem a família, que continua sendo a responsável central pelos cuidados. Está 
certo que as políticas públicas procuram dar apoio a essa função familiar, inclusive estimulando formas de cuidados que não recaiam somente sobre a mulher. De modo geral, está ocorrendo uma melhora e um aperfeiçoamento das políticas e programas que já existiam. O setor público atua na regulação e no financiamento dos serviços de atenção à dependência e na estruturação da rede de serviços públicos de apoio às famílias. Assim, se antes o Estado de Bem-Estar era desenvolvido por intermédio da assistência social ou da previdência social com regime contributivo, atualmente, a proteção é destinada a todos os cidadãos em situação de dependência, porém mediante a descentralização dos serviços para os municípios com financiamento do Estado e a participação do usuário.

Diante do aumento da esperança de vida e da demanda por cuidados, em decorrência da fragilidade e dependência das pessoas com 80 anos e mais de idade, a tendência é a de pensões e de aposentadorias minguarem a cada ano. De acordo com Esping-Andersen (2011), "a regra geral é as pessoas idosas consumirem em torno de 3,2 vezes mais de atenção de saúde que os demais, e até 4,1 vezes mais os idosos acima de 75 anos" (p.103, tradução nossa) ${ }^{7}$. Portanto, é certo que haverá incremento de gastos destinados aos cuidados das pessoas idosas.

A Organização das Nações Unidas, ao vislumbrar, por meio de seus estudos, que o envelhecimento populacional seria um tema de grande envergadura a ser discutido com todas as Nações signatárias, desde 1982, vem realizando eventos sobre o tema com a participação dos governos e da sociedade civil, tema que será tratado a seguir.

\footnotetext{
${ }^{7}$ Texto original: Por regla general, las personas ancianas consumen alrededor 3,2 veces más de atención sanitaria que los demás, y asta 4,1 veces más para los mayores de 75 años.
} 


\title{
3 POLÍTICA DE CRIAÇÃO DE GARANTIAS FORMAIS DOS DIREITOS DOS IDOSOS EM ÂMBITO INTERNACIONAL
}

\begin{abstract}
As pessoas idosas não são somente muito mais numerosas que antigamente; elas se integram também mais espontaneamente à sociedade; esta se vê obrigada a decidir a respeito de seu estatuto e esta decisão só pode ser tomada em nível governamental. A velhice se tornou objeto de uma política.
\end{abstract}

Simone de Beauvoir

Organização das Nações Unidas - ONU, por ocasião da Assembleia Geral realizada em 1973, chamou atenção sobre a necessidade de proteger os direitos das pessoas idosas. Porém, somente em 1982, foi elaborado um documento para balizar as políticas destinadas a esse segmento populacional.

Em 1982, foi realizada a 1a Assembleia Mundial sobre Envelhecimento, em Viena; e, por ocasião da 68ª Sessão Plenária das Nações Unidas, em 14 de dezembro de 1990, em cumprimento à Resolução no 46/106, foi designada a data de $1^{\circ}$ de outubro como o Dia Internacional das Pessoas Idosas.

Em 1991, a ONU editou a Resolução № 46, instituindo os princípios dessa Organização em favor das pessoas idosas, os quais são: independência, participação, assistência, autorrealização e dignidade, que devem ser assegurados às pessoas idosas para que estas realmente possam ter um envelhecimento ativo e digno.

O Comitê dos Direitos Econômicos, Sociais e Culturais - DESC afirmou, em 1999, que os Estados partícipes do Pacto do DESC devem prestar especial atenção ao fomento e à proteção às pessoas idosas no que diz respeito: à igualdade de direitos entre homens e mulheres, ao direito ao trabalho, à previdência social, à proteção da família, a um nível de vida adequado, à saúde física e mental, à educação e à cultura. Essa atenção está bem especificada no quadro abaixo, em que dispositivos normativos (à esquerda) estão desdobrados em obrigações correspondentes (à direita). 


\begin{tabular}{|c|c|}
\hline $\begin{array}{l}\text { Artículo del Pacto Internacional } \\
\text { de Derechos Económicos, Sociales } \\
\text { y Culturales (PIDESC) }\end{array}$ & $\begin{array}{l}\text { Interpretación del Comité de Derechos Económicos, } \\
\text { Sociales y Culturales (CDESC) }\end{array}$ \\
\hline $\begin{array}{l}\text { Igualdad de derechos para hombres } \\
\text { y mujeres } \\
\text { (artículo 3) }\end{array}$ & $\begin{array}{l}\text { Los Estados partes deberían prestar atención especial a } \\
\text { las mujeres de edad avanzada y crear subsidios no } \\
\text { contributivos u otro tipo de ayudas para todas las } \\
\text { personas mayores que, con independencia de su género, } \\
\text { carezcan de recursos. }\end{array}$ \\
\hline $\begin{array}{l}\text { Derecho al trabajo } \\
\text { (artículos } 6,7 \text { y } 8 \text { ) }\end{array}$ & $\begin{array}{l}\text { Los Estados partes deben adoptar medidas que eviten la } \\
\text { discriminación por edad en el empleo y la profesión; que } \\
\text { garanticen condiciones seguras de trabajo hasta la } \\
\text { jubilación, y que otorguen a los trabajadores de edad } \\
\text { avanzada empleos que les permitan hacer un mejor uso } \\
\text { de su experiencia y conocimientos, además de poner en } \\
\text { marcha programas preparatorios de jubilación. }\end{array}$ \\
\hline $\begin{array}{l}\text { Derecho a la seguridad social } \\
\text { (artículo 9) }\end{array}$ & $\begin{array}{l}\text { Los Estados partes deben fijar regímenes generales para } \\
\text { un seguro de vejez obligatorio; establecer una edad de } \\
\text { jubilación flexible; proporcionar subsídios de vejez no } \\
\text { contributivos y otras ayudas a todas las personas que, } \\
\text { alcanzada la edad establecida en la legislación nacional y } \\
\text { careciendo de ingresos, no hayan finalizado el período de } \\
\text { calificación contributivo y no tengan acceso a una } \\
\text { pensión de vejez u otro tipo de prestación de seguridad } \\
\text { social o ayuda. }\end{array}$ \\
\hline $\begin{array}{l}\text { Derecho de protección de la familia } \\
\text { (artículo 10) }\end{array}$ & $\begin{array}{l}\text { Los gobiernos y las organizaciones no gubernamentales } \\
\text { deben crear servicios sociales para apoyar a la familia } \\
\text { cuando existan personas mayores en el hogar, y aplicar } \\
\text { medidas especiales destinadas a las familias de bajos } \\
\text { ingresos que deseen mantener en su seno a las personas } \\
\text { de edad avanzada. }\end{array}$ \\
\hline $\begin{array}{l}\text { Derecho a un nivel de vida adecuado } \\
\text { (artículo 11) }\end{array}$ & $\begin{array}{l}\text { Las personas mayores deberían lograr satisfacer sus } \\
\text { necesidades básicas de alimentación, ingresos, cuidados } \\
\text { y autosuficiencia, entre otras. También deben } \\
\text { desarrollarse políticas que favorezcan la permanencia en } \\
\text { sus hogares por medio del mejoramiento y la adaptación } \\
\text { de sus viviendas. }\end{array}$ \\
\hline Derecho a la salud física y mental (artículo 12) & $\begin{array}{l}\text { Facilitar el acceso a intervenciones sanitarias dirigidas a } \\
\text { mantener la salud en la vejez con una perspectiva del } \\
\text { ciclo de vida. }\end{array}$ \\
\hline $\begin{array}{l}\text { Derecho a la educación y la cultura } \\
\text { (artículo 13) }\end{array}$ & $\begin{array}{l}\text { Debe ser abordado desde dos ángulos diferentes y a la } \\
\text { vez complementarios: i) el derecho de la persona de edad } \\
\text { a disfrutar de programas educativos, y ii) la posibilidad de } \\
\text { poner sus conocimientos y experiencias a disposición de } \\
\text { las generaciones más jóvenes. }\end{array}$ \\
\hline
\end{tabular}

Quadro 2 - Comité de Derechos Económicos, Sociales Y Culturales: contenidos de la Observación General № 6

Fuente: Elaborado sobre la base de Naciones Unidas, "Los derechos económicos, sociales y culturales de las personas de edad", Observación general N 6 (E/C.12/1995/16/Rev.1), Ginebra, Comité de Derechos Económicos, Sociales y Culturales, 1995 (HUENCHUAN, 2013, p. 25). 
O Protocolo de San Salvador, assinado pelos Estados integrantes da Organização dos Estados Americanos por ocasião do Décimo Período de Sessões da Assembleia Geral, em 17 de novembros de 1988, é o único documento de caráter juridicamente vinculante para América Latina e Caribe que inclui normas sobre os direitos básicos das pessoas idosas. Além disso, obriga os Estados a garantirem progressivamente proteção especial à velhice para que os idosos desfrutem de alimentação e de atenção médica especializada, de execução de programas trabalhistas específicos, que possibilitem a realização de atividades produtivas e a promoção da formação de organizações sociais destinadas a melhorar a qualidade de vida das pessoas idosas. Esse Protocolo foi aprovado pelo Decreto Legislativo no 56, de 19 de abril de 1995; porém o governo brasileiro só depositou o instrumento de adesão a esse Ato em 21 de agosto de 1996, apesar de o referido Protocolo ter sido amplamente contemplado no Estatuto do Idoso vigente.

Após vinte anos da la Assembleia Mundial, a Organização das Nações Unidas realizou a II Assembleia Mundial sobre o Envelhecimento no período de 8 a 12 de abril de 2002, em Madrid. A autora desta tese participou dessa Assembleia e assistiu, naquela cidade, pessoas idosas protestando nas ruas por não terem sido chamadas ou convidadas a participar de um evento que lhes dizia respeito. Efetivamente, esse é um aspecto que precisa ser considerado pelos promotores dos eventos internacionais para que as suas recomendações incorporem os pleitos de seu público-alvo. Nessa assembleia, pelo que se pôde observar, as organizações não governamentais participaram, sem, contudo, terem direito à voz. Em compensação, elas realizaram o Fórum Mundial das ONG's sobre envelhecimento, nos dias 5 a 9 de abril de 2002, em Madrid, e encaminharam os resultados de suas análises e discussões à Organização das Nações Unidas.

Dentre as recomendações do referido Fórum Mundial das ONG's, destacam-se: a aplicação da Declaração Universal dos Direitos Humanos para todos os cidadãos, a plena inclusão das pessoas idosas na vida social e econômica de suas respectivas sociedades, o aproveitamento de suas capacidades e experiências e a defesa de seus direitos diante de qualquer discriminação.

Entre 19 a 21 de novembro de 2003, foi realizada em Santiago do Chile, a I Conferência Regional Intergovernamental sobre Envelhecimento - América Latina e Caribe sob a organização do governo chileno em conjunto com a CEPAL, o Fundo das Nações Unidas sobre População - UNFPA, a Organização Panamericana de Saúde - OPS, a Organização Internacional do Trabalho - OIT, o Banco Interamericano de Desenvolvimento - BID, Banco Mundial e Programa sobre Envelhecimento das Nações Unidas. Essa Conferência foi a primeira de caráter intergovernamental sobre envelhecimento realizada na região, como instância de análise e de intercâmbio a respeito da situação do 
envelhecimento e de pessoas idosas. Nessa ocasião, foi acordada pelos países participantes a estratégia regional de implementação do Plano de Ação Internacional de Madri sobre o Envelhecimento (2004). Essa estratégia estabelece metas, objetivos e recomendações para ações em favor das pessoas idosas em cada uma das três áreas prioritárias acordadas no Plano de Madri, destacando-se as que se referem ao cuidado.

Nesse quesito "cuidado", a questão da sobrecarga que ele representa para a família geralmente para uma só pessoa que quase sempre é a mulher ou outra pessoa idosa - foi considerada alvo da seguinte recomendação: de que é preciso reconhecer o papel que a mulher tem exercido em relação aos serviços e cuidados e tomar as devidas medidas para que essas atividades sejam também responsabilidades dos homens (CEPAL, 2004, p. 16) ${ }^{8}$.

Foi reconhecido, ademais, que existem um desenvolvimento limitado e escassa fiscalização das regulamentações que regem o funcionamento das instituições de longa permanência, nas quais não há fiscalização adequada do respeito aos direitos humanos e tampouco monitoramento das obrigações internacionais assumidas pelos Estados, no que diz respeito ao tratamento e aos cuidados das pessoas idosas que residem nas ditas instituições, sendo definido como meta o acesso das pessoas idosas aos serviços de saúde integrais e adequados às suas necessidades, garantindo-se, assim, uma melhor qualidade de vida na velhice e na preservação de sua capacidade funcional e autonomia (CEPAL, 2004, p. 17).

E, como objetivo de uma cobertura universal das pessoas idosas nos serviços de saúde, que seja incorporado o envelhecimento como componente essencial das legislações e políticas nacionais de saúde com as seguintes recomendações:

- Desenvolver um sistema de saúde que enfatize a promoção da saúde, a prevenção de doenças e a provisão de cuidados equitativos e dignos às pessoas idosas;

- Formular políticas definindo os cuidados de que necessitam as pessoas idosas e os mecanismos de acesso a eles;

- Implementar um plano integral de saúde, dotando-o, progressivamente, dos recursos necessários tanto humanos como financeiros, no qual sejam coordenados os serviços destinados ao cuidados da saúde das pessoas idosas, em âmbito local, regional e nacional.

E ainda:

\footnotetext{
${ }^{8}$ Texto original: es preciso reconocer el rol que la mujer ha ejercido en la provisión de servicios y cuidados y arbitrar las medidas para favorecer que dichas actividades sean también responsabilidad de los hombres.
} 
- Fortalecer a capacidade governamental e institucional para estabelecer, difundir e fazer cumprir regras e normas que regulamentem os estabelecimentos que oferecem cuidados de longa duração às pessoas idosas, especialmente as dependentes, visando a proteção de seus direitos e de dignidade e o combate a violações dos mesmos;

- Estabelecer estreita colaboração multisetorial para educar os provedores e usuários desses serviços acerca da qualidade dos cuidados e dos direitos humanos, liberdades e condições de vida ótimas para seu bemestar, com o estabelecimento e difusão de mecanismos eficazes de transmissão de queixas de seus usuários e familiares;

- Fomentar a criação de redes de apoio aos cuidadores familiares para viabilizar a permanência da pessoa idosa em seu lar e prevenir o esgotamento físico e mental do cuidador;

- Fomentar a criação de alternativas comunitárias aos cuidados de longa duração às pessoas idosas (CEPAL, 2004, p. 18-20).

No cerne dessas recomendações, destacam-se as seguintes ideias-forças: envelhecimento ativo, protagonismo, respeito às diferenças das pessoas idosas, consideração do ciclo de vida e solidariedade intergeracional.

Pautada pelas mesmas ideias, a organização da sociedade civil realizou, no período de 17 a 20 de junho de 2003, a Reunião Regional da Sociedade Civil sobre Envelhecimento, em Santiago do Chile. Na ocasião, o Grupo Interagencial sobre Envelhecimento - GIE apresentou um documento com uma síntese do processo de seguimento da Assembleia Mundial do Envelhecimento, na qual estavam detalhadas as atividades de seguimento paralelo desenvolvido pela sociedade civil. Ademais, o documento concluía com uma seção de anexos que continham os acordos e as recomendações das reuniões dos especialistas.

O GIE é integrado pela CEPAL, Organização Panamericana de Saúde (OPS), Fundo de População das Nações Unidas - UNFPA, Programa de Envelhecimento das Nações Unidas, Banco Interamericano de Desenvolvimento - BID e Organização Internacional do Trabalho - OIT, e tem o apoio da Divisão de População das Nações Unidas e da Secretaria de Cooperação Técnica Iberoamericana. Esse grupo elaborou um plano de atividades que contemplava três documentos de Recomendações de Políticas referentes às Redes de Apoio Social, Saúde e Segurança Econômica das Pessoas Idosas. Tais recomendações têm por objetivo geral fortalecer as redes de apoio social aos idosos para melhorar sua qualidade de vida e potencializar seu desenvolvimento como sujeito de direito. 
Os princípios gerais nos quais se sustentam essas recomendações são:

- Pessoas idosas como sujeitos de direitos: referente ao respeito e à garantia da titularidade de direitos individuais e de grupos de pessoas idosas. Essa concepção implica também responsabilidades e deveres com o conjunto da sociedade;

- Independência e autonomia, entendida como a capacidade das pessoas idosas de desenvolver e de manter autonomia (econômicas, físicas e outras) que lhes permita decidir e controlar sua vida e seu destino;

- Integralidade das pessoas idosas e seus contextos, entendida como uma concepção holística do idoso como ser humano integral, com características diversas e, portanto, necessidades distintas. Implica não só reconhecer as dimensões social, cultural, histórica e biomédica da velhice e do envelhecimento, mas também o reconhecimento das relações de interdependência das pessoas idosas no seu contexto familiar, comunitário e societário;

-Enfoque do ciclo de vida e visão prospectiva, referindo-se à articulação direta da velhice com outras etapas prévias da vida, levando em conta as especificidades de gênero. Requer uma visão a longo prazo que conceba o envelhecimento como um processo e não só uma etapa da vida e, por conseguinte, dando maior importância às ações que fomentem a solidariedade e o intercâmbio intergeracional;

- Complementariedade das ações em âmbito nacional, regional e local, tendo em vista a necessidade de acordos e coordenação entre distintos âmbitos de intervenção das ações dirigidas às pessoas idosas (CEPAL, 2003).

A seguir, apresentam-se as recomendações sobre redes de apoio das pessoas idosas estruturadas em quatro áreas de planejamento e intervenção:

-Pessoas idosas como sujeitos de direitos;

- Disponibilidade dos sistemas de apoio social das pessoas idosas;

- Igualdade dos sistemas de apoio social às pessoas idosas;

- Mecanismos de seguimento. 


\subsection{PESSOAS IDOSAS COMO SUJEITOS DE DIREITO}

Esta área tem como objetivos habilitar as pessoas idosas como sujeitos de direitos e promover o reconhecimento de sua contribuição à sociedade, elegendo como estratégia a criação de condições favoráveis ao seu empoderamento, a saber:

- Vigiar o cumprimento dos direitos básicos das pessoas, tais como: acesso à alimentação, à água, à habitação, ao vestuário, à atenção à saúde e à concessão adequada de renda;

- Promover a elaboração de uma Convenção Interamericana dos Direitos das Pessoas Idosas e fomentar a compatibilização da legislação nacional com os princípios e as normas instituídas em âmbito internacional sobre os direitos das pessoas idosas;

- Elaborar leis e normas que deem respostas eficazes aos maus tratos e à violência praticada contra as pessoas idosas seja eles físicos, sejam emocionais e econômicos;

- Promulgar leis, quando necessário, e eliminar a legislação discriminatória, para combater a exclusão social das pessoas idosas.

- Realizar campanhas amplas e permanentes de sensibilização, via meios de comunicação de massa, direcionadas a promover uma imagem positiva do envelhecimento e da velhice e combater os estereótipos negativos sobre as pessoas idosas;

- Promover a conscientização das pessoas idosas e da sociedade em relação à discriminação por idade;

- Promover ações para combater o abandono e o autoabandono das pessoas idosas;

- Promover práticas de controle cidadão na formulação e na aplicação de políticas que afetem diretamente o bem-estar e a defesa dos direitos das pessoas idosas.

\subsection{DISPONIBILIDADE DOS SISTEMAS DE APOIO SOCIAL ÀS PESSOAS IDOSAS}

Com o objetivo de aumentar a disponibilidade dos sistemas de apoio social às pessoas idosas e, como estratégia, desenvolver iniciativas para complementaridade dos sistemas formais e informais de apoio, definiu-se como medidas: 
- Promover estratégias de coordenação interinstitucional para o desenvolvimento de serviços comunitários para pessoas idosas que tenham optado por ou devam viver só;

- Facilitar intervenções na etapa laboral que apoiem as pessoas idosas, em especial os homens, em sua passagem para a aposentadoria, com vista a minorar os efeitos negativos da deteriorização/redução de sua rede social;

- Fomentar a criação de grupos locais de voluntariado, formados por pessoas idosas e outros interessados, dirigidos a dar apoio às pessoas idosas;

- Traçar estratégias de capacitação sistemática, formal e de alta qualidade técnica, para aqueles que dão apoio às pessoas idosas;

- $\quad$ Criar, por parte do Estado e/ou organizações da sociedade civil, serviços sociais e comunitários de apoio à família quando existam pessoas idosas em seus domicílios que requeiram cuidados especiais por dependência física ou mental;

- Aplicar medidas, por parte do Estado, de apoio (econômico, social e psicológico) destinado às famílias de baixa renda que desejem cuidar das pessoas idosas, de idade mais avançadas, com necessidade de cuidado especial.

\subsection{IGUALDADE DOS SISTEMAS DE APOIO SOCIAL DAS PESSOAS IDOSAS}

Com o objetivo de diminuir as desigualdades dos sistemas de apoio social às pessoas idosas e de reduzir as diferenças de acesso e benefícios presentes de fontes formais e informais de apoio, foram definidas as seguintes estratégias:

- Garantir às pessoas idosas o desfrute de cuidados e a proteção da família e da comunidade em conformidade com os valores da sociedade;

- Desenvolver ações específicas de segurança pessoal, apoio afetivo, acesso à informação, à recreação, com ênfase nos grupos de pessoas idosas com mais desvantagens;

- Desenvolver ações específicas para as pessoas idosas migrantes que se encontrem com dificuldades de adaptação;

- Fortalecer os mecanismos tradicionais de apoio social nas comunidades indígenas e rurais; 
- Promover mecanismos inovadores de apoio social às pessoas idosas que vivem isoladas;

- Reconhecer o papel fundamental das mulheres de idade mediana no cuidado das pessoas idosas e favorecer iniciativas que lhes ajudem a cumprir adequadamente seu papel, preservando seus direitos e integridade.

\subsection{MECANISMOS DE SEGUIMENTO}

Têm tais mecanismos o objetivo de desenvolver formas de seguimento para implementação das recomendações supra-apresentadas e, como estratégia, desenvolver indicadores e fontes apropriados para medir as redes de apoio social às pessoas idosas. Para tanto, foram previstas as seguintes medidas:

- Criar um sistema de indicadores que meçam o nível de empoderamento, disponibilidade, acesso e uso de fontes formais e informais de apoio às pessoas idosas e avanços legais relacionados aos direitos das pessoas idosas;

- Criar fontes de dados públicos, acessíveis e homogêneos em âmbito regional e nacional que permitam o conhecimento da situação das pessoas idosas, considerando o gênero, as coortes de idade, a etnia, a zona residencial e outras variáveis relevantes;

- Desenvolver bases de dados de organizações sociais que trabalham com e para pessoas idosas em âmbito comunitário, favorecendo a coordenação de suas atividades;

- Incorporar a perspectiva da idade e gênero nas análises e na exploração dos dados dos censos e pesquisas domiciliares;

- Desenhar e incorporar, com periodicidade, módulos especiais relacionados à qualidade de vida das pessoas idosas, tais como: dependência, transição do emprego para a aposentadoria, previdência social etc.

A sociedade civil que atua na defesa dos direitos da pessoa idosa ganha, a cada dia, força e agrega mais pessoas na luta pelos direitos desse segmento social. O documento que resultou do GIE e foi aprovado na Reunião Regional da Sociedade Civil sobre Envelhecimento é amplo e foi discutido com especialistas, fornecendo grandes contribuições aos governos da América Latina e Caribe. Nele, as pessoas idosas que apresentam 
dependência para o desenvolvimento de suas atividades de vida diária são contempladas, faltando apenas à vontade política dos governos para aplicar as medidas propostas.

A Resolução n 44/1, da Comissão de Desenvolvimento Social da ONU estipulou ao Secretário-Geral que apresentasse, em seu $45^{\circ}$ período de sessões, um informe sobre os principais acontecimentos na esfera do envelhecimento desde a II Assembleia Mundial sobre Envelhecimento. Em atenção à referida resolução, foi elaborado pelo Secretário Geral (2006) um Informe contendo os principais acontecimentos regionais e mundiais sobre envelhecimento, os quais demonstram que esse processo representa um ganho social de primeira magnitude, além de manifestação de progresso e de melhora da condição humana. No entanto, esse tema, como se sabe, levanta preocupação geral e exige adoção de medidas políticas concretas bem definidas e orientadas para o futuro nos planos nacional, regional e mundial dos governos.

Os países em desenvolvimento, diz o Informe, têm pouco tempo para adaptar-se ao acelerado processo de envelhecimento populacional, cuja tendência revela que:

\begin{abstract}
El segmento de la población de edad que crece con mayor rapidez es el de las personas de 80 años o más, es decir, las "personas de mayor edad", cuya tasa de crecimiento se ha incrementado hasta llegar a un $4,2 \%$ anual. Además, está previsto que el número de personas de 100 o más años de edad se multiplique por 13 y pase de 287.000 en 2006 a 3,7 millones en 2050. Estos cambios demográficos también están modificando las ideas acerca de a quién se considera "persona de edad" e induciendo a los países a diferenciar diversas categorías de personas de edad (ONU, 2006, p. 4).
\end{abstract}

O Informe registra, ainda, que, nesses países, persistem as desigualdades generalizadas de disponibilidade de serviços de assistência social para as pessoas idosas e de programas de pensões. Em, alguns países, a maioria das pessoas trabalha no setor econômico não estruturado, tendo dificuldades para instituir, financiar e manter planos tradicionais de pensões contributivas.

Por outro lado, nos países desenvolvidos, as principais medidas adotadas têm sido a de frear o endividamento crescente com programas de assistência social. Dentre essas medidas, consta a de elevar a idade para aposentadoria já que se aumentou a expectativa de vida. A tendência é que os países ajustem os índices de seus programas de previdência social em função das variações demográficas, da variação da expectativa de vida ou das taxas de inatividade das pessoas idosas.

A implantação de serviços de atenção à saúde e assistencial exequíveis, sustentáveis e de boa qualidade, sobretudo de atenção de longa duração, é uma das dificuldades mais agudas para as sociedades que envelhecem progressivamente. Um dos aspectos importantes são os serviços de atenção preventivas, terapêuticas, de 
reabilitação, que incluirão a prestação de cuidados paliativos e o aumento do apoio aos cuidadores.

A defesa de direitos das pessoas idosas é um elemento imprescindível de toda política referente ao envelhecimento e um pré-requisito necessário para o bem-estar desse público-alvo.

Dentre as indicações contidas no referido Informe, destaca-se que a Comissão de Desenvolvimento Social tem a função de aconselhar os governos que redobrem seus esforços para integrar as pessoas idosas na corrente geral de suas políticas de desenvolvimento, estimular atuações coordenadas para melhorar as condições laborais dos trabalhadores de mais idade; suprimir obstáculos que dificultam a contratação e a retenção desses trabalhadores; promover a empregabilidade dos idosos e melhorar os serviços de assistência que têm direito.

As reuniões ou conferências regionais são de suma importância para as avaliações do seguimento do Plano de Madri sobre Envelhecimento. No entanto, como o plano não possui caráter vinculante, os governos não têm dado tanta importância ao envelhecimento populacional em seus países, em especial os em desenvolvimento, como o Brasil.

A sociedade civil também deve atentar para o fato de que são imperiosas a implementação de políticas públicas que assegurem os direitos humanos das pessoas idosas e a adoção, pelos governos, de estratégias, programas, projetos e serviços que assegurem o bem-estar desse público-alvo; de que as implicações sociais e econômicas do envelhecimento são numerosas. Portanto, faz-se necessária pressão junto ao Estado para que este ponha em prática as ações previstas nas legislações vigentes em cada país.

Como já citado, em 2007, foi realizada a II Conferência Intergovernamental sobre o Envelhecimento na América Latina e Caribe, da qual resultou a Declaração de Brasília. O Governo brasileiro apresentou, em seu informe nacional sobre a aplicação da Estratégia Regional de Implementação para América Latina e Caribe, do Plano de Ação Internacional de Madri sobre envelhecimento, seus avanços por intermédio da Secretaria Especial de Direitos Humanos da Presidência da República (SEDH). Tais avanços indicavam a promoção do fortalecimento das instâncias de controle democrático (Conselhos de Direito) por meio das seguintes ações: realização da I Conferência Nacional dos Diretos da Pessoa Idosa; elaboração do Plano de Ação para o Enfrentamento da Violência Contra a Pessoa Idosa; promoção de audiências públicas sobre as Instituições de Longa Permanência para Idosos; realização de cursos e oficinas de capacitação de conselheiros; promoção de cursos de capacitação de recursos humanos para profissionais que lidam com a população idosa; estimulo à integração e à articulação dos Conselhos de Defesa da 
Pessoa Idosa nos três níveis de governo (nacional, estadual, municipal e Distrito Federal), com a participação da sociedade civil. Foi também mencionado que o governo empenhouse em atribuir caráter deliberativo a todos os conselhos de direitos e em instruir os conselheiros quanto à importância de seu papel e de sua participação na atividade de controle democrático (INFORME BRASIL, 2007).

Dentre as iniciativas de cunho normativo de grande relevância do governo brasileiro, destacam-se: sanção do Estatuto do Idoso - Lei no 10.741/2003 - e da Lei n 11.433/2006, que instituiu 1ำ de outubro como o Dia Nacional do Idoso; a regulamentação da Lei no 5.296/2004, de Acessibilidade; publicação do Decreto № 5.934/2006, que regulamenta o Art. 40 do Estatuto do Idoso, referente à utilização dos transportes coletivos interestaduais para idosos com renda de até dois salários mínimos que poderão adquirir passagens gratuitas e com descontos de 50\%; aprovação da Resolução da Diretoria Colegiada - RDC/283/2005, da Agência Nacional de Vigilância Sanitária-ANVISA, que instituiu norma técnica definidora de padrões de funcionamento das Instituições de Longa Permanência para Idosos; publicação da Portaria ํㅗ 5.228/2006, que aprova a Política de Saúde para Pessoa Idosa e da Portaria nº 2.529/2006, que instituiu a internação domiciliar no âmbito do Sistema Único de Saúde.

Em 2006, foi firmado convênio entre a Secretaria Especial de Direitos Humanos SEDH e o Instituto de Pesquisa Econômica Aplicada - IPEA para realização de pesquisa nacional sobre as "Características das Instituições de Longa Permanência para Idosos ILPI", resultando em publicação na qual constam os números de ILPI's no Brasil, suas condições e a dos usuários.

Das ações realizadas pela SEDH em 2004-2005, figuram 52 cursos de capacitação para prevenção da violência contra a pessoa idosa, contemplando 649 pessoas; capacitação para a cidadania em todos os Estados da federação, formando 1.930 pessoas; cursos para gestores de ILPI's, capacitando 550 pessoas; formação de 400 conselheiros em direitos humanos; encontros anuais de conselhos de idosos, congregando público ao redor de 350 pessoas; capacitação de 500 operadores do sistema de transportes coletivos. Em 2006 e 2007, foram realizadas: oficinas para capacitação de conselheiros e gestores, formando 200 pessoas; oficina para preparação de recursos humanos para atuarem nos centros integrados de prevenção à violência contra a pessoa idosa. Foram, ainda, editadas 70.000 publicações para subsidiar cursos e oficinas, em especial os indicadores de condições de vida das pessoas idosas como recomendação do Plano de Madri. Além disso, o Ministério da Ciência e Tecnologia, em parceria com a Universidade Católica de Brasília, por intermédio da Fundação Universa, realizou pesquisa sobre violência contra as pessoas idosas, contemplando ocorrências, vítimas e seus agressores. E, ainda, foram implantados 
por meio de convênios com estados, municípios e organizações não governamentais Centros de Prevenção a Violência contra a Pessoa Idosa.

Em 2007, foi realizado, em Brasília, o Fórum das Organizações não governamentais, sob o patrocínio do Serviço Social do Comércio - SESC - Direção Nacional, em parceria com Organizações não governamentais da América Latina e do Caribe, destacando-se as seguintes participações: Coordenação de Organismos Regionais da Sociedade Civil da América Latina e Caribe - CORV; Programa Regional Adulto Mayor Cáritas na América Latina e da PRAM - Cáritas. Os resultados desse Fórum foram divulgados e repassados para CEPAL, nos quais constam as seguintes exigências:

-Que os organismos competentes conheçam e cumpram os compromissos estabelecidos pelos representantes dos governos na Declaração Política da II Assembleia Mundial sobre Envelhecimento, nas conferências da Organização das Nações Unidas, na Declaração do Milênio; e incorporem eficazmente o envelhecimento nas suas estratégias, políticas e ações socioeconômicas;

- Que os estados e governos promovam o irrestrito respeito aos direitos humanos das pessoas idosas e que seja elaborada a Convenção Internacional dos Diretos das Pessoas Idosas;

- Que haja a participação da sociedade civil, em especial das pessoas idosas, na formulação, na implementação, no monitoramento e na avaliação, tanto das políticas públicas, como dos serviços, programas e projetos em âmbito local, nacional e internacional na área do envelhecimento.

Essas foram algumas das principais reivindicações da sociedade civil em defesa dos direitos das pessoas idosas, apresentadas nesse Fórum, do qual participaram 200 pessoas e representantes de 16 países.

Em março de 2008, em Buenos Aires, por ocasião da 11a reunião de Altas Autoridades de Direitos Humanos e Chancelarias do MERCOSUL e Membros Associados, foi realizado o seminário Regional "Idosos: discriminação, direitos humanos e políticas públicas". Nessa ocasião, os países participantes concordaram em estudar a possibilidade de fazer uma declaração de apoio do MERCOSUL à criação de uma Convenção sobre os Direitos das Pessoas Idosas.

Em Santo Domingo, na República Dominicana, por ocasião do XXXII Período de Sessão da Comissão Econômica para América Latina e Caribe - CEPAL foi aprovada, em junho de 2008, a Resolução nํ 644. E, nessa Sessão, além de ser ratificada a Declaração 
de Brasília, a Secretaria Executiva da CEPAL solicitou assessoramento técnico da própria CEPAL para realização das reuniões de seguimento da referida Declaração, em particular no que se refere ao tema de mecanismos internacionais de proteção dos direitos das pessoas idosas.

A primeira reunião de seguimento da Declaração de Brasília foi organizada pela Secretaria Especial dos Direitos Humanos - SEDH e Ministério das Relações Exteriores, com o apoio técnico do Centro Latino Americano e Caribenho de Demografia-CELADE Divisão de População da CEPAL e do Fundo de População das Nações Unidas - UNFPA. Essa reunião foi realizada nos dias 16 e 17 de setembro, na cidade do Rio de Janeiro. Dela participaram treze países da América Latina e Caribe, Espanha, Portugal; representantes da CELADE, CEPAL, Departamento de Assuntos Econômicos e Sociais das Nações Unidas UM/DESA, Comitê do Pacto de Direitos Econômico, Sociais e Culturais - PDESC, organizações não governamentais internacionais, Cáritas Alemã, Associação Internacional de Gerontologia, Global Action on Ageing, HelpAge Internacional; organismos brasileiros, como: Associação dos Membros do Ministério Público de Defesa do Idoso e Pessoas com Deficiência - AMPID; Associação Nacional de Gerontologia; Sociedade Brasileira de Geriatria e Gerontologia; Serviço Social do Comércio - SESC; Centro Latino Americano de Violência e Saúde - CLAVES - FIOCRUZ; Confederação Brasileira de Aposentados Pensionistas e Idosos - COBAP; Associação Nacional de Defensores Públicos; Centro Interdisciplinar de Apoio e Pesquisa em Envelhecimento - CIAPE; representantes dos Conselhos de Defesa do Idoso do Piauí, Alagoas, Rio de Janeiro; Associação Municipal de Apoio Comunitário - AMAC; Assembleia Permanente pelos Direitos Humanos da Argentina; Centro de Capacitação e Desenvolvimento do Chile; Confederação de Pensionistas e Idosos de Curaçao; Frente Parlamentar de Entidades Civis e Militares em Defesa da Previdência Pública e dos Conselhos de Defesa dos Direitos da Pessoa Idosa; Associação Brasileira de Psicologia Aplicada, Grupo Iberoamericano Interdisciplinar de Gerontologia da Universidade de Sevilha.

Nessa reunião, expositores do Brasil e dos organismos internacionais abordaram a importância de uma Convenção dos Direitos das Pessoas Idosas, do reforço aos mecanismos de segmento do Plano de Ação Internacional de Madri sobre Envelhecimento, do enfoque dos direitos nos temas relacionados à velhice e da designação de um relator de direitos humanos para velar pelos direitos da pessoa idosa.

O ponto relevante da reunião foi a minuta da criação da Convenção dos Direitos da Pessoa Idosa apresentada pela Associação dos Membros do Ministério Público de Defesa do Idoso e Pessoas com Deficiência - AMPID, a qual foi repassada à representante da Argentina com o objetivo de dar seguimento às discussões. A esse respeito, vale salientar 
que a representante do governo argentino solicitou da AMPID a minuta da Convenção porque o então Subsecretário de Promoção e Defesa dos Direitos Humanos da SEDH se negou a apresentá-la como proposta brasileira, sob a justificativa de que o Brasil parecia estar impondo o documento aos demais países. Felizmente, o governo argentino abraçou a causa, dando ensejo a que essa minuta servisse de base à convenção que vem sendo discutida no âmbito da OEA. A AMPID, por sua vez, continuou dando grande contribuição à defesa dos direitos da pessoa idosa ao ponto de, como o Governo brasileiro se negou a apresentar a minuta da criação da Convenção, ter defendido como instituição não governamental um documento internacional que seja juridicamente vinculante e assegure os direitos humanos das pessoas idosas e ainda, segue participando ativamente das reuniões do GT de composição aberta sobre a defesa dos direitos humanos da pessoa idosa no âmbito da Organização das Nações Unidas.

Em 21 e 22 de maio de 2009, o governo argentino realizou a segunda reunião de seguimento da Declaração de Brasília, contando com o apoio da CEPAL, CELADE e da UNFPA, e com a participação de 22 países da América Latina, Caribe e Europa; dos Estados Unidos e organizações não governamentais. Contou, ainda, com a presença de organismos internacionais, tais como: Organização dos Estados Americanos - OEA; Comissão Interamericana de Direitos Humanos; Organização Panamericana de Saúde OPS/OMS; Departamento de Assuntos Econômicos e Sociais das Nações Unidas UN/DESA; Organização Internacional do Trabalho e o Fundo das Nações Unidas para População. Presentes também representantes da Organização Iberoamericana de Seguridade Social - OISS; International Network for the Prevention of Elder Abuse; Cáritas Alemã; Associação Internacional de Gerontologia; Health Foundation of South Flórida; HelpAge Internacional; Conferência Interamericana de Seguridade Social - CISS do Centro de Estudos de Seguridade Social - CIESS e a Associação Internacional de Geriatria e Gerontologia.

Os resultados dessa reunião foram apresentados pelo governo da Argentina ao Secretário-Geral da Organização das Nações Unidas e dos Estados Americanos, sob a forma de um documento que tinha como principal justificativa a necessidade de uma Convenção, além de conter uma lista de temas que deveriam ser incluídos em um instrumento de caráter vinculante.

O governo argentino se empenhou de tal maneira que assumiu a presidência do GT de Composição Aberta sobre os direitos da pessoa idosa, constituído pela Organização das Nações Unidas, e também a presidência do GT sobre a Convenção no âmbito da Organização dos Estados Americanos - OEA, conduzindo muito bem todos os trabalhos. 
A III Reunião de seguimento foi realizada nos dias 5 e 6 de outubro de 2009, em Santiago do Chile. Organizada pelo Governo chileno por intermédio do Serviço Nacional do Adulto Maior - SENAMA, com apoio da CEPAL, CELADE, Organização Panamericana de Saúde - OPS, UNFPA, Organização Iberoamericana de Seguridade Social-OISS e Rede Intergovernamental Iberoamericana de Cooperação Técnica-RIICOTEC, ela contou com a participação de 24 países. Nesse evento, foi discutido o documento da convenção. À Secretaria da CEPAL foi atribuída a tarefa de elaborar uma proposta de estratégia sobre como avançar os artigos 24 e 25, da Declaração de Brasília, e de elaborar conteúdos mínimos que deverão estar presentes, desde a perspectiva da América Latina e do Caribe, em uma convenção internacional sobre os direitos humanos das pessoas idosas. Foi sugerido, ainda, que a referida proposta fosse apresentada na reunião seguinte do Comitê de População e Desenvolvimento da CEPAL a ser realizada em 2010, que os Ministérios das Relações Exteriores de cada país fizessem gestão junto às suas missões na Organização dos Estados Americanos - OEA para a realização de uma sessão especial de especialistas e representantes de governos com vista à preparação de uma Convenção Interamericana de Direitos da Pessoa Idosa, com apoio da OPS e CEPAL - tal como foi estabelecido pela Assembleia Geral da OEA em sua Resolução AG/RES 2.455 do 39º período de sessões celebrado em San Pedro, Sula (Honduras, 4 de julho de 2009).

Por ocasião da 5a Conferência das Américas, realizada em abril de 2009, em Trinidad e Tobago, foi assinada a Declaração de Porto Espanha que, em seu artigo 42, dispõe que: "Neste contexto promoveremos um marco regional e com apoio da OPAS e CEPAL um exame sobre a viabilidade de elaborar uma Convenção Interamericana sobre os direitos das pessoas idosas" (DECLARAÇÃO DE PORTO ESPANHA, OEA, 2009).

Durante a realização do XXXIX Período Ordinário de Sessões da Organização dos Estados Americanos, em San Pedro Sula, Honduras, entre os dias 2 a 4 de junho de 2009, sob o AG2455-XXXIX-O/09, ficou assentado o que segue:

Recordando os resultados da Segunda Assembleia Mundial sobre Envelhecimento (Madrid, 2002) e as duas Conferências Regionais Intergovernamentais (Santiago, 2003 e Brasília, 2007);

Ressaltando que, na Declaração de Compromisso de Porto Espanha, as Chefes e os Chefes de Estado e de Governo das Américas comprometeram-se a continuar 'trabalhando para incorporar temas referentes aos idosos nas agendas das políticas públicas' e a promover 'no âmbito regional e com o apoio da OPAS e da CEPAL, uma análise da viabilidade de uma convenção interamericana sobre os direitos dos idosos',

RESOLVE:

1. Manifestar preocupação com a insuficiência de estudos e relatórios em nível hemisférico a respeito da institucionalidade e dos mecanismos singulares relacionados aos problemas das pessoas idosas, especialmente as violações e infrações de seus direitos, o que torna necessário avançar na 
criação de instrumentos internacionais para a sua devida avaliação e na adoção de medidas de proteção.

2. Encarregar o Conselho Permanente de incluir em sua agenda a abordagem da problemática que afeta as pessoas idosas no Hemisfério, com a perspectiva de promover uma cooperação regional para identificar suas necessidades específicas e as políticas públicas adequadas ao seu tratamento.

3. Instar o Conselho Permanente a convocar, com o apoio da Secretaria de Assuntos Jurídicos e da Secretaria Executiva da Comissão Interamericana de Direitos Humanos (CIDH), se possível, uma sessão especial de representantes nacionais e peritos oriundos do setor acadêmico e da sociedade civil, bem como de organismos internacionais, com o objetivo de trocar informações e boas práticas, e estudar a viabilidade da elaboração de uma convenção interamericana sobre os direitos das pessoas idosas.

4. Solicitar ao Conselho Permanente que informe a Assembleia Geral, no $40^{\circ}$ Período Ordinário de Sessões, sobre a implementação dos mandatos constantes desta resolução, cuja execução estará sujeita à disponibilidade de recursos financeiros alocados no orçamento-programa da Organização e de outros recursos (OEA, 2009, AG2455-XXXIX-O/09). ${ }^{9}$

Os presidentes dos Estados componentes do MERCOSUL e Estados Associados, reunidos na cidade de San Juan, República Argentina, em 3 de março de 2010, por ocasião da XXXIX Reunião do Mercado Comum, fizeram o seguinte comunicado:

Reiteramos o interesse em aprofundar o tratamento dos direitos das pessoas idosas na Organização dos Estados Americanos e nas Nações Unidas, com o objetivo de contar com um instrumento internacional

9 Texto original: RECORDANDO los resultados de la Segunda Asamblea Mundial sobre el Envejecimiento (Madrid 2002) y las dos Conferencias Regionales Intergubernamentales (Santiago 2003 y Brasilia 2007); DESTACANDO que en la Declaración de Compromiso de Puerto España, ' las Jefas y Jefes de Estado y de Gobierno de las Américas se comprometieron a continuar "trabajando para incorporar los temas de la vejez en las agendas de política pública" y a promover "en el marco regional y con el apoyo de la OPS y de la CEPAL, un examen sobre la viabilidad de elaborar una convención interamericana sobre los derechos de las personas mayores"; RESUELVE:

1. Manifestar su preocupación por la insuficiencia de estudios e informes a nivel hemisférico respecto de la institucionalidad y mecanismos particulares relativos a los problemas de las personas adultas mayores, en especial de las violaciones e infracciones a sus derechos, lo que hace necesario avanzar en la creación de instrumentos internacionales para su debida evaluación y en la adopción de medidas para su protección.

2. Encomendar al Consejo Permanente que incluya en su agenda el tratamiento de la problemática que afecta a las personas adultas mayores en el Hemisferio, en la perspectiva de promover una cooperación regional para identificar sus necesidades específicas y las políticas públicas adecuadas para su tratamiento.

3. Instar al Consejo Permanente a que convoque, con el concurso de la Secretaría de Asuntos Jurídicos y la Secretaría Ejecutiva de la Comisión Interamericana de Derechos Humanos (CIDH), de ser posible, a una sesión especial de representantes nacionales y expertos provenientes del sector académico y de la sociedad civil, así como de organismos internacionales, con el objetivo de intercambiar información y buenas prácticas, y examinar la viabilidad de elaborar una convención interamericana sobre los derechos de las personas adultas mayores.

4. Solicitar al Consejo Permanente que informe a la Asamblea General, en su cuadragésimo período ordinario de sesiones, sobre el cumplimiento de la presente resolución, cuya ejecución estará sujeta a la disponibilidad de recursos financieros en el programa-presupuesto de la Organización y otros recursos. 
juridicamente vinculante que assegure os direitos dos mesmos e uma velhice com dignidade. ${ }^{10}$

Além disso, durante a realização da sessão do Comitê Especial da CEPAL sobre População e Desenvolvimento, realizada entre 12 a 14 de maio de 2010, foi apresentada à Secretaria Executiva do referido órgão a seguinte solicitação: que transmitisse ao Secretário-Geral da Organização das Nações Unidas o interesse dos países presentes de constituir um grupo de trabalho encarregado de liderar o processo de elaboração de um tratado internacional para proteger os direitos das pessoas idosas.

Em cumprimento à referida solicitação, a Secretária-Executiva da CEPAL enviou carta ao Secretário-Geral da ONU, Ban Ki-moon, no dia 22 de outubro de 2010, na qual afirmava que os países da América Latina e do Caribe ficariam muito agradecidos em relação ao interesse de levar em frente a preparação para uma convenção que protegesse especificamente os direitos das pessoas idosas.

No mês de outubro de 2010, foi realizada uma sessão especial do Conselho Permanente da Organização dos Estados Americanos - OEA, que contou com a participação de representantes dos Estados membros, e especialistas em direitos humanos e da sociedade civil. Nessa ocasião, foi discutida a viabilidade de se criar um documento de caráter vinculante que protegesse e promovesse os direitos das pessoas idosas nas Américas, de acordo com a Resolução AG/RES 2.562 (XL0/10), reiterando a realização de uma reunião com especialistas, a qual ocorreu em outubro do mesmo ano.

Em 2011, a Assembleia Geral da OEA, por intermédio da AG/RES 2.654 (XLI-O/11), solicitou ao Conselho Permanente que criasse um grupo de trabalho composto por representantes nacionais, especialistas da área acadêmica, da sociedade civil, de organismos internacionais e agências especializadas. O GT apresentou uma minuta de convenção à Comissão de Assuntos Jurídicos e Políticos, a qual foi encaminhada ao Conselho Permanente no final do primeiro semestre de 2012.

De acordo com a Resolução AG/RES 2.726 (XLII-O/12), foi solicitado ao Conselho Permanente ampliar o mandato do Grupo de Trabalho com o objetivo de negociação formal do projeto de convenção interamericana sobre os direitos das pessoas idosas, para que fosse apresentado no 43ํㅜ Período Ordinário de sessões a ser realizado em 2013. Desde essa resolução, foram realizadas 19 reuniões formais e oito informais durante o processo de negociação que foi até maio de 2013.

\footnotetext{
${ }^{10}$ Texto original: En ese contexto, reiteraron su interés en profundizar el tratamiento de los Derechos de los Adultos Mayores en la Organización de Estados Americanos y en las Naciones Unidas, con el objetivo de contar con un instrumento internacional jurídicamente vinculante que asegure los derechos de los mismos, promoviendo de esa forma una vejez con dignidad.
} 
Apesar de o projeto de Convenção estar bastante avançado, o Grupo de Trabalho acima mencionado decidiu solicitar a extensão do mandato por intermédio da Resolução AG/RES 2.792 (XLIII-O/13). Em decorrência, a Assembleia Geral da OEA ampliou o mandato do Grupo de Trabalho até o segundo semestre de 2013, culminando com o processo formal de negociação do projeto de Convenção Interamericana sobre os Direitos Humanos das Pessoas Idosas.

A Resolução nº 65/182, da Assembleia Geral da Organização das Nações Unidas, realizada em 21 de dezembro de 2010, criou um grupo de trabalho de composição aberta, da qual podem participar todos os seus membros, com o objetivo de impulsionar a implementação do Plano de Madrid, visando aumentar a proteção dos direitos humanos das pessoas idosas. Para tanto, deveria ser examinado o marco internacional vigente em matéria desses direitos e identificadas suas possíveis deficiências para que fosse encontrada a melhor forma de saná-las, incluindo a realização de estudos sobre a viabilidade de novos instrumentos e medidas.

Entre 18 e 20 de abril de 2011, aconteceu, em Nova York, a primeira sessão do Grupo de Trabalho criado pela Resolução acima citada. Durante as atividades, foi analisada a situação dos direitos das pessoas idosas em âmbitos internacional e regional. Essa primeira sessão enfocou os estudos da atual situação dos direitos humanos das pessoas idosas ao redor do mundo e incluiu dois painéis de discussão sobre marcos internacional e regional de direitos humanos e sua contribuição à proteção dos direitos na velhice.

A segunda sessão do Grupo de Trabalho ocorreu no período de $1^{\circ}$ a 4 de agosto de 2011, também em Nova York. O referido GT concentrou-se na análise dos direitos econômicos, sociais e culturais das pessoas idosas, apresentando cinco painéis temáticos sobre discriminação e discriminação dupla múltipla; direito à saúde das pessoas idosas; violência e abuso na velhice; proteção social das pessoas idosas; idade e exclusão social. Sobre esse conjunto de temas, observou-se que todas as discussões estiveram voltadas para contemplar os paradigmas dos direitos humanos, com vista ao fortalecimento cada vez maior dos caminhos para se chegar a uma convenção.

Os países participantes das discussões em Nova York tiveram oportunidade tanto de fazer intervenções sobre os direitos das pessoas idosas de seus respectivos países, assim como de intercambiar opiniões para identificar as possíveis brechas de proteção dos direitos na velhice em âmbito internacional. Os países da América Latina e do Caribe demonstraram estar de acordo com a instituição de uma convenção de Defesa dos Direitos da pessoa idosa; porém a União Europeia não se manifestou favoravelmente, no que foi acompanhada 
pelos Estados Unidos, que só concordaram com a designação de um relator para velar pelos direitos das pessoas idosas.

A Resolução AG/RES 2.654 (XLI-O/11) sobre a "Proteção dos Direitos Humanos das Pessoas Idosas" incumbiu ao Conselho permanente a criação de um grupo de trabalho para preparar, antes do final de 2012, um informe sobre a situação das pessoas idosas no hemisfério. Nesse informe, também deveria constar a efetividade dos instrumentos universais e regionais vinculantes de direitos humanos com relação à proteção dos direitos das pessoas idosas, sendo delegada essa atribuição à Comissão de Assuntos Jurídicos e Políticos (CAJP). Esta, por sua vez, constituiu o Grupo de Trabalho sobre Direitos das Pessoas Idosas, designando como presidenta a representante Alterna da República Argentina.

O referido Informe expôs que a região enfrenta uma nova situação demográfica e epidemiológica, que demanda aos países se adequarem aos novos contextos e adotarem programas e medidas específicas de proteção aos direitos das pessoas idosas.

Em relação às normativas aprovadas, cada vez mais fica evidente que a necessidade da criação de um tratado que proteja os direitos humanos das pessoas idosas é imperiosa. Com a aprovação de um tratado de âmbito internacional, os benefícios serão inúmeros e os Estados terão que assegurar esses direitos.

Diante do cenário apresentado, ressalta-se a necessidade de serem criadas as normativas mais precisas quanto à garantia dos direitos das pessoas idosas, visto que as existentes não propiciam meios para que os Estados possam traçar políticas públicas e ações mais consistentes, o melhor, as normas existentes, por não terem caráter vinculante, são até adotadas pelos Estados, como é o caso do Brasil, porém não possuem recursos especificados para sua implementação.

Em janeiro de 2012, a presidenta do GT da OEA encaminhou às delegações o documento enviado pela CEPAL referente "a los lineamientos para una convención de los derechos de las personas mayores/edad", para que fosse utilizado como referência e as delegações enviassem comentários e propostas que achassem pertinentes, em cumprimento à Resolução AG/RES 2.654 (XLI-O/11).

Infelizmente, no Brasil, o referido documento, que era a minuta da Convenção, não foi repassado pelo órgão coordenador da Política Nacional do Idoso (Secretaria de Direitos Humanos) aos demais Ministérios para que dessem as suas contribuições, principalmente no tocante à previdência, assistência social e saúde. 
A Organização das Nações Unidas tem inserido em suas agendas das Assembleias Gerais o tema sobre o Seguimento da II Assembleia Mundial sobre o Envelhecimento. Prova disso é que, nos 66ำ e 67ำ períodos de sessões, o Secretário-Geral apresentou informe sobre o cenário mundial do envelhecimento populacional e solicitou aos governos que fizessem esforço para aplicar o Plano de Madri sobre o Envelhecimento. Em relação aos cuidados, solicita aos governos que assegurem condições que permitam às famílias e comunidades proporcionarem proteção às pessoas à medida que estas vão envelhecendo.

Em agosto de 2012, foram convidados todos os países signatários da Organização das Nações Unidas para dar continuidade às discussões do GT de composição aberta sobre os direitos da pessoa idosa. A maioria dos que estiveram presentes expuseram as políticas para as pessoas idosas praticadas em seus respectivos países, assim como concordaram em fazer algo que assegurasse os direitos humanos das pessoas idosas.

Alguns Estados-membros foram claros quanto a considerar o envelhecimento como questão de bem-estar e merecedor de apoio, porém afirmaram que todos os temas sobre direitos humanos deveriam ser esgotados antes de qualquer tipo de normalização.

Nesse mesmo encontro, foi abordada a necessidade de os tratados de direitos humanos serem agilizados, tanto no que se refere à sua adoção, quanto à sua ratificação. Também foi informado que a Convenção sobre os Direitos das Pessoas com Deficiência foi iniciada pelo México em 2001 e, em dezembro de 2006, foi aprovada.

O representante da Malásia, que, pela primeira vez, participou do GT, ressaltou a importância do diálogo nesse encontro, convencendo-se da necessidade de uma convenção sobre os direitos humanos das pessoas idosas no sentido de afirmar e fortalecer esses direitos.

Alguns Estados-Membros, dentre os quais os Estados Unidos, o Canadá e os países da União Europeia posicionaram-se contrários às normas específicas para assegurar os Direitos Humanos da Pessoa Idosa, sugerindo que fosse revisado o Plano de Madri, uma vez que a sua aplicação não tem sido monitorada, que fosse incluído o debate na Comissão de Desenvolvimento Social e as agências das Nações Unidas tivessem maior envolvimento.

As organizações não governamentais sugeriram convidar representantes das comissões de direitos humanos com o objetivo de serem discutidos os benefícios econômicos, o empoderamento das pessoas idosas para o desenvolvimento econômico, a permissão para que as pessoas idosas exponham suas experiências vividas e os mecanismos regionais de direitos humanos que estão sendo criados em seu benefício. A referida sugestão, além de aceita, foi confirmada pelos países latino-americanos e africanos. 
A missão da Argentina convidou as organizações não governamentais para uma reunião, em sua sede, com o objetivo de traçar estratégias de pressão junto aos seus governos - no caso, os que são contra a convenção - para que concordem em dar continuidade à discussão do tema, com a proposta de se produzir um documento de âmbito internacional e juridicamente vinculante.

Por fim, convém destacar que, apesar de não ter conseguido o apoio das grandes potências, o GT de composição aberta propôs-se a seguir discutindo o tema. Porém, a missão da Argentina deverá traçar estratégias para que as reuniões não tenham a mesma metodologia e que sejam mais proativas e com resultados mais positivos. Nessa terceira sessão do GT, houve maior participação dos países africanos e asiáticos, em comparação com as duas reuniões anteriores do GT.

Em 2013, a reunião do citado GT foi realizada no período de 12 a 15 de agosto. A metodologia adotada foi como das demais e vários países expuseram as ações desenvolvidas em benefício das pessoas idosas.

A União Europeia informou que 2012 foi o Ano Europeu do Envelhecimento Ativo, no qual várias atividades científicas foram realizadas, porém continua reafirmando que possuem um compêndio de normas e que o Plano de Madri vem sendo seguido em suas recomendações, não havendo necessidade de uma Convenção dos Direitos da Pessoa Idosa. O que precisa ser feito, afirma, é trabalhar para que os direitos humanos sejam assegurados a esse segmento populacional e que saúde e educação sejam concedidas a todos.

Enquanto isso, Argentina, Chile, Costa Rica, El Salvador, Brasil e alguns países africanos presentes à reunião continuam reafirmando a importância de uma Convenção. A Argentina coordenou um encontro com vários países da América Latina e Caribe, resultando na criação de um grupo "Amigos do Idoso" com o objetivo de lutarem pela Convenção.

Dentre os temas abordados, destacam-se: a vida profissional mais longa, a não discriminação, a saúde e a independência, os cuidados paliativos e a solidariedade intergeracional. As organizações não governamentais contribuíram com um documento que faz referência ao incentivo ao envelhecimento ativo, saudável e às campanhas, ressaltando a importância das pessoas idosas.

A representante da Missão da Argentina junto à Organização dos Estados Americanos - OEA ressaltou a relevância de uma Convenção que assegure os Direitos Humanos das Pessoas Idosas, informando que as discussões sobre o tema estão em um estágio bastante avançado no âmbito da OEA. 
A Resolução no 2.726 da OEA (2012) dispõe sobre um projeto amplo que fixa, como objetivo, promover e proteger todos os direitos humanos das pessoas idosas. Isso constitui um aporte para a sociedade garantir direito à saúde, educação, dentre outros. A minuta da convenção respalda a perspectiva de gênero, a situação da pobreza dos idosos, a seguridade social, os cuidados, o acesso à justiça e a tomada de consciência para eliminar os estereótipos em relação às pessoas idosas. O GT da OEA, criado com a finalidade de discutir a convenção, ficou de se reunir extraordinariamente, em dezembro de 2013, para aprovar o documento que vem sendo discutido desde 2012, porém a reunião deverá ser em junho de 2015.

Os Estados Unidos não têm respaldado a convenção da OEA por entender que os direitos dos idosos devem ser protegidos independentemente de convenção.

Em setembro de 2013, foi aprovado pelo GT da OEA o Plano de Trabalho sobre a proteção dos direitos humanos das pessoas idosas. O referido Plano servirá como marco geral para as atividades do grupo durante o período 2013-2014, ao qual poderão ser incorporadas as modificações que sejam requeridas durante os trabalhos para assegurar melhores resultados.

Em 19 de julho de 2013, o Secretário-Geral das Nações Unidas apresentou o Informe referente às resoluções da Assembleia Geral 67/143, intitulada "Seguimento da II Assembleia Mundial sobre o Envelhecimento", e da Assembleia Geral 67/139, intitulada "Um instrumento jurídico internacional amplo e integral para promover e proteger os direitos e a dignidade das pessoas idosas". O informe examina três esferas prioritárias-chaves para aplicação do Plano de Ação Internacional de Madri sobre o Envelhecimento de 2002, baseado nos resultados de âmbito mundial do segundo exame de avaliação do Plano de Ação realizado durante o $51^{\circ}$ período de sessões da Comissão de Desenvolvimento Social, a saber: acesso das pessoas idosas ao trabalho e ao emprego decente; maus tratos e violência contra as pessoas idosa e saúde mental.

Porém, uma das conquistas obtidas em 25 de setembro de 2013 foi a aprovação pelo Conselho de Direitos Humanos das Nações Unidas, no seu $24^{\circ}$ período de sessão, da Resolução no 20/24 (A/HRC/24/L.37/Rev.1), apresentada pelo governo da Argentina e com a participação e a aprovação dos seguintes países: Argentina, Bolívia (Estado Plurinacional de), Bósnia y Herzegovina, Brasil, Chile, Colômbia, Costa Rica, Cuba, Djibuti, Equador, EI Salvador, Etiópia, Guatemala, Honduras, México, Panamá, Paraguai, Peru, Turquia, Uruguai, Venezuela (República Bolivariana de). Tal Resolução dispunha sobre nomeação por três anos de um especialista independente para zelar pelos direitos humanos das pessoas idosas e para encomendar-lhe o seguinte mandato: 
[...] a) Evaluar la aplicación de los instrumentos internacionales vigentes por lo que se refiere a las personas de edad, determinando al mismo tiempo las mejores prácticas en la aplicación de la legislación vigente relativa a la promoción y protección de los derechos de las personas de edad y las deficiencias en la aplicación de la legislación vigente;

b) Tener en cuenta las opiniones de las partes interesadas, como Estados, mecanismos regionales de derechos humanos, instituciones nacionales de derechos humanos, organizaciones de la sociedad civil e instituciones académicas pertinentes;

c) Crear conciencia sobre los problemas que enfrentan las personas de edad para el ejercicio de todos los derechos humanos y velar por que las personas de edad reciban información sobre esos derechos;

d) Trabajar, en cooperación con los Estados, para fomentar la aplicación de medidas que contribuyan a la promoción y protección de los derechos de las personas de edad;

e) Integrar en su labor la perspectiva de género y de la discapacidad y prestar especial atención a las mujeres de edad, las personas con discapacidad, los afrodescendientes, las personas pertenecientes a pueblos indígenas, las personas pertenecientes a minorías nacionales o étnicas, religiosas y lingüísticas, las personas del medio rural, las personas que viven en la calle y los refugiados, entre otros grupos;

f) Evaluar las consecuencias en materia de derechos humanos de la aplicación del Plan de Acción Internacional de Madrid sobre el Envejecimiento;

g) Trabajar en estrecha coordinación, evitando al mismo tiempo las duplicaciones innecesarias, con el Grupo de Trabajo de composición abierta sobre el envejecimiento, con otros procedimientos especiales y órganos subsidiarios del Consejo de Derechos Humanos, con los órganos pertinentes de las Naciones Unidas y con los órganos de tratados (ONU, 2013).

O quinto período de sessão do GT de composição aberta sobre os direitos humanos da pessoa idosa foi realizado nos dias 30, 31 de julho e $1^{\circ}$ de agosto de 2013, na sede da Organização das Nações Unidas, em Nova York.

De acordo com a Resolução n 24/20, a Sra Rosa Kornfeld foi nomeada especialista independente do Conselho de Direitos Humanos das Nações Unidas, com a função de avaliar os instrumentos de direitos humanos existentes que contemplam a pessoa idosa, identificando as melhores práticas e suas eventuais deficiências, além de trocar opiniões com outros especialistas de universidades e da sociedade civil.

O referido período de sessão contou com exposições dos países ali representados e exposições de especialistas na área do envelhecimento. Houve um evento paralelo sobre fragilidade da pessoa idosa para identificar a melhor política sobre o tema, inclusive a adotada pela OMS sobre os cuidados de longa duração. Neste evento, foi pautada a necessidade de: garantir discussão regular e coerente no seio das Nações Unidas sobre as questões do envelhecimento; envolver, nessa discussão, as pessoas idosas e a sociedade civil; primar para que essas discussões não sejam só de natureza normativa, mas que 
tenham um foco mais acurado no acompanhamento dos idosos no sistema de direitos humanos; implementar com urgência o Plano de Madri.

A Grécia, representando os países da Europa Ocidental, expôs a importância de se inserir ações positivas nos documentos da ONU sobre envelhecimento e sobre o uso de eventos paralelos, por parte dos países, para que apontem soluções para determinados problemas e, ainda, para que o envelhecimento seja inserido nos planos estratégicos da ONU, do Fundo das Nações Unidas para População, da ONU Mulheres, da OIT, com vistas ao desenvolvimento de políticas acessíveis.

Os Estados Unidos pediu aos demais Estados que se concentrem em medidas práticas e oportunas para tratar do abuso e da violência contra a pessoa idosa, informando que foi assinada uma lei pelo Presidente Obama, que cria um conselho composto de 12 chefes de agências do governo para tratar do referido tema.

A China conta com 200 milhões de pessoas idosas e diz que os governos devem desempenhar papel de liderança por meio da incorporação do envelhecimento nos planos de desenvolvimento, além de estabelecer um sistema legal para proteger os direitos das pessoas idosas criando comissões locais.

O Brasil abordou o Estatuto do Idoso e informou que o Conselho Nacional dos Direitos do Idoso é um exemplo da sociedade civil no monitoramento e na aplicação das políticas públicas destinadas às pessoas idosas. Junto com a Argentina, propôs-se a apresentar uma Resolução ao Conselho de Direitos Humanos, em Genebra, que incluísse pedido de criação de uma convenção no âmbito dos Estados Americanos, cuja previsão é junho de 2015. Esta Convenção Interamericana é considerada de grande importância para o Brasil.

A presença da Sra. Rosa Kornfeld, nesta reunião, foi de suma importância. Na próxima, ela apresentará cenário das políticas públicas existentes nos países em benefício da pessoa idosa, suas boas práticas e deficiências, o qual, certamente, muito contribuirá para subsidiar um documento em âmbito internacional que assegure os direitos humanos das pessoas idosas.

Para a autora desta tese, todas as normativas de direitos humanos e de defesa dos direitos das pessoas idosas da Organização das Nações Unidas e da Organização dos Estados Americanos - OEA, assim como o Plano de Viena, não tiveram tanta influência como o Plano de Madrid e a Declaração de Brasília. Esta última teve grande impacto nas políticas para pessoas idosas não só na América Latina e no Caribe, mas em âmbito mundial. Entretanto, têm-se ciência e consciência de que, com o acelerado processo de envelhecimento populacional, não há mais como postergar a implantação e a implementação de políticas públicas que assegurem os direitos das pessoas idosas, assim 
como o incentivo ao envelhecimento ativo para que essas pessoas possam gozar de uma velhice digna e com qualidade de vida. 


\section{EVOLUÇÃO E TENDÊNCIAS DAS NORMATIVAS E POLÍTICAS DE PROTEÇÃO AO IDOSO NO BRASIL}

O problema filosófico dos direitos do homem não pode ser dissociado do estudo dos problemas históricos, sociais, econômicos, psicológicos, inerentes à sua realização: o problema dos fins não pode ser dissociado do problema dos meios.

Norberto Bobbio

Embora, nesta tese, as normativas e políticas de proteção ao idoso no Brasil tenham como parâmetro de influência as normativas internacionais contemporâneas, indicadas no capítulo anterior, considera-se pertinente apresentar, aqui, uma breve remissão ao passado, pois não só em influências externas as políticas públicas brasileiras se pautaram, assim como não só por meio de legislações e políticas elas foram determinadas. Como explicitado no Capítulo I, tais políticas têm determinações estruturais e históricas particulares que, não obstante fazerem parte de um processo mundializado, elas apresentam, tanto na sua origem quanto no seu desenvolvimento, características próprias do contexto político-institucional e da realidade socioeconômica em que se constituíram.

Portanto, com o intuito de não descurar dessas particularidades, muitas vezes congênitas, na análise da relação nem sempre harmônica entre normatização e política de proteção ao idoso - hoje, de abrangência supranacional - que se fará a reflexão a seguir.

O estudo da legislação da política brasileira de proteção ao idoso mostrará que essa legislação evoluiu a partir da crescente intensidade de conflitos de classes gerados pela produção e pela acumulação de bens, provocando ingerência do Estado no âmbito das relações de trabalho. Foram muitos os anos de luta e as conquistas vieram gradativamente, inicialmente por categorias funcionais, mais organizadas, combativas ou mais estratégicas para a economia do país.

Em 1890, foi editado o Decreto ํㅡ 565, de 12 de junho, que concede aposentadoria para os empregados da Estrada de Ferro Central do Brasil. Portanto, esse Decreto garantiu direitos de aposentadoria a todos os trabalhadores ferroviários do setor público nacional. Nesse mesmo ano, por meio do Decreto no 439, também foi criado o fundo de pensão para os funcionários do Ministério da Fazenda e da Estrada de Ferro Central do Brasil. No ano de 1903, foi reconhecido aos profissionais da agricultura e das indústrias rurais o direito de organizar e de formar sindicatos. Os sindicatos demonstraram a importância da organização social e de luta, principalmente no que dizia respeito às conquistas por direitos relacionadas ao trabalho. Assim, suas organizações foram marcantes desde a Revolução Industrial: 
[...] em 1923, inspirados pelos industriais, com os quais mantinha contatos estreitos (...), o Deputado paulista Eloy Chaves apresentou projeto logo transformado no Decreto-Lei de no 4.682, criando as Caixas de Aposentados e Pensão dos Ferroviários. Tipicamente ela se destinava à criação de um fundo, mediante a contribuição dos empregados, dos empregadores e do Estado (este através de recursos adicionais de tributação e, portanto, mediante recursos extraídos do público), com o objetivo de garantir parte do fluxo da renda normalmente auferida pelo empregado, no momento em que ele se desligasse da produção por velhice, invalidez ou por tempo de serviço - ou a seus dependentes em caso de morte, além da assistência médica (...) Não se tratava de um direito de cidadania, inerente a todos os membros de uma comunidade nacional, quando não mais em condições de participar do processo de acumulação, mas de um compromisso a rigor entre os membros de uma empresa e seus proprietários (SANTOS, 1979, p. 24).

Essa Caixa de Aposentadoria e Pensão cobria apenas os empregados de uma só. E, em assim sendo, a Previdência Social brasileira começou se caracterizando, basicamente, por estabelecer uma dimensão extra nos contratos de trabalho, em que "a empresa e seus empregados comprometiam-se a sustentar o empregado atual, no futuro, em troca de parcela de renda deste, no presente" (SANTOS, 1979, p. 24). Essa modalidade de proteção social guardava semelhança com o sistema de Seguridade Social instituído na Alemanha, no século XIX, pelo chanceler conservador Otto Von Bismarck, o qual ficou conhecido como modelo profissional por cobrir, sob a forma de seguro, apenas os trabalhadores inseridos no mercado de trabalho. Quem estivesse fora desse mercado e não pudesse contribuir no presente para sua segurança no futuro ficava desprotegido pelo Estado.

Em 1926, já funcionavam 33 caixas de Aposentadorias e Pensão com as mesmas características iniciais. Contudo, pelo Decreto Legislativo no 5.128, o governo foi autorizado a criar o Instituto de Previdência para os servidores da União, no qual o Estado passou a desempenhar as funções correspondentes ao do empregador privado. E, por meio do Decreto $n^{\circ}$ 19.646, de 31 de março de 1927, foi instituída a competência exclusiva do Estado para tratar da Previdência dos servidores públicos, dando origem ao Instituto de Pensões e Aposentadorias dos Servidores do Estado.

Todavia, em 1932, já estavam em funcionamento 140 Caixas de Aposentadoria e Pensões, cobrindo 189.482 segurados ativos, 10.279 aposentados e 8.820 pensionistas, ficando claro que, enquanto o Estado respondia lenta e seletivamente às demandas de ampliação da proteção social por parte da classe trabalhadora, as empresas avançavam na sua cobertura previdenciária, de caráter compensatório, mediante acordos privados de seguro entre empregadores e empregados.

No ano de 1933, foi criado, pelo Decreto 22.872, de 29 de julho, o Instituto de Aposentadoria e Pensões dos Marítimos - IAPM, com financiamento tripartido, semelhante aos das Caixas. E esse acontecimento, segundo Santos (1979), marcou uma inflexão no 
comportamento do Estado, já que este demonstrava uma preocupação não apenas em usar a Previdência Social como mecanismo de reorientação de processo de acumulação, mas também de proteção do trabalhador. Um exemplo a ser citado foi que "todos os profissionais marítimos, no caso do IAPM, estavam qualificados para receber os mesmos benefícios, independentemente da empresa à qual estivessem ligados produtivamente" (SANTOS, 1979, p. 32). Logo, a partir de então, tornou-se possível associar a Previdência com direitos coletivos.

A Constituição de 1934 introduziu um capítulo sobre a ordem econômica e social, reconhecendo a existência dos direitos sociais. Ainda em 1934, seguindo a mesma sistemática do IAPM, foram criados o Instituto de Aposentadoria e Pensões dos Comerciários - IAPC e o Instituto de Aposentadoria e Pensões dos Bancários - IAPB. E, após o golpe de 1937, protagonizado por Getúlio Vargas, surgiram o Instituto de Aposentadoria e Pensões dos Industriários - IAPI, o Instituto de Aposentadoria e Pensões dos Trabalhadores e Empregados em Cargas - IAPETEC e o Instituto de Previdência e Aposentadoria dos Servidores do Estado - IPASE. Mas, nesse processo, fica evidente que, não obstante o interesse governamental de construir uma política preventiva de proteção à velhice dos trabalhadores, com aposentadoria e pensões asseguradas pelo Estado, havia a intenção governamental de dividir a classe trabalhadora nas suas lutas e reivindicações sociais e controlá-la por meio de negociações com categorias profissionais particulares.

Em 1948, o sistema de Previdência Social era constituído por 30 Caixas de Aposentadorias e Pensões - CAPS e 6 Institutos de Aposentadorias e Pensões - IAPs, cobrindo aproximadamente 3.000 .000 segurados ativos, 158.800 aposentados e 171.000 dependentes. Vale destacar que, na Constituição democrática de 1946, no Capítulo da Ordem Social, não foi inserida nenhuma inovação. Porém, de acordo com Santos:

[...] a vinculação da política social, em sentido estrito, à política de acumulação não poderia ser mais óbvia e apenas repetia o que ficara claro, já desde 1933, a saber, que a política social do governo estava essencialmente ligada à política de acumulação e todo problema, do ponto de vista governamental, consistia em conciliar sua política de acumulação que não exacerbasse as iniqüidades sociais a ponto de torná-las ameaçadoras, e uma política voltada para o ideal da equidade que não comprometesse, e se possível ajudasse, o esforço de acumulação (SANTOS, 1979, p. 33).

Ao longo do tempo, a Lei Eloy Chaves foi sendo alterada, assim como a legislação que sucedeu as Caixas de Aposentadoria e Pensões - CAPs. O Decreto no 4.682, de 24 de janeiro de 1923, embora prevendo assistência médica aos beneficiários, não fixava fundos a serem destinados a tais serviços. Em $1^{\circ}$ de outubro de 1931, foi instituído o Decreto nํㅡ 20.465, que disciplinava a reforma da legislação das CAPs, além de fixar $8 \%$ do fundo 
disponível a ser gasto em assistência médica, sendo este montante ampliado para 10\% de acordo com o disposto no Decreto no 21.081, de fevereiro de 1932.

Por fim, a Lei Orgânica da Previdência Social (Lei n³.807, de 26 de agosto de 1960) unificou a legislação aplicável aos Institutos. Contudo, as imposições do governo demonstram que não se poderia ter uma proteção social universal e evidenciaram a possibilidade de corte na assistência médica mesmo de segurados que contribuíam com a manutenção superavitária do Sistema Previdenciário.

Com o Golpe Militar de 1964 e a instituição de um regime ditatorial que durou vinte e um ano ocorreu maior velocidade à expansão da cobertura previdenciária à população brasileira, sem, no entanto, vinculação entre benefícios sociais e acumulação de riquezas, pavimentando caminhos da universalização segmentada, para usar a expressão de Rodriguez Cabrero (apud PEREIRA, 2008); ou seja, só teria cobertura quem fosse segurado, o que contribuía para ratificar as desigualdades sociais. Mas, aqui se apresenta uma particularidade da Política Social brasileira que merece ser ressaltada, visto que ela aparece, de forma invertida, nos momentos de redemocratização do país. Trata-se do fato da Política Social no Brasil ter sido mais expansiva nos períodos de ditadura, quando era usada para compensar o cerceamento dos direitos civis e políticos, do que nos períodos de democracia, quando os direitos civis e políticos servem de pretexto para restringir políticas que deveriam concretizar direitos sociais. E esse fato ressalta a fragilidade da democracia brasileira, inclusive na atualidade, de domínio neoliberal.

Na mesma década, sob o Decreto no 72, de 21 de novembro de 1966, foi criado o Instituto Nacional de Previdência Social (INPS). Esse Instituto unificou todos os institutos existentes, com exceção do Instituto de Pensões e Aposentadoria dos Servidores do Estado - IPASE. Uniformizou também todos os benefícios e serviços e unificou toda parte políticoadministrativa das agências estatais incumbidas de promover a proteção social, independentemente da categoria profissional, sendo incluídos igualmente os trabalhadores rurais, empregados domésticos e autônomos.

Com a criação do INPS, iniciou-se um processo de modernização da Previdência, incrementando-se o número de contribuintes e de beneficiários; porém desintegram-se os esquemas associativos, e a política social foi submetida a uma racionalidade privatizante, resultando na queda da qualidade dos serviços. Nesse processo, foram definidos os espaços entre o público e o privado e, em 1975, instituído o Sistema Nacional de Saúde e a compra de serviços no mercado pelo Estado, transferindo a função provedora para a iniciativa privada. A partir daí, tiveram início as privatizações do sistema de saúde, 
desonerando o Estado e passando a responsabilidade ao contribuinte, o que representou retrocesso na política social no Brasil.

Para beneficiar a população do campo, foi criado o Programa de Assistência ao Trabalhador Rural - FUNRURAL, por meio da Lei Complementar ํㅜ 11, de 25 de maio de 1971, que previa a concessão de benefícios de aposentadoria por velhice e invalidez, pensão por morte, auxílio-funeral, serviço de saúde e serviço social (melhoria dos hábitos e de suas condições de assistência, mediante ajuda pessoal, nos desajustamentos individuais e da unidade familiar e, predominantemente em suas diversidades). E a aposentadoria correspondia a $50 \%$ do salário mínimo.

Outro tema de particularidade brasileira que deve ser enfatizado é a valorização, até hoje, da chamada por Santos (1979) de "cidadania regulada", em que só eram reconhecidos aqueles que tivessem a carteira de trabalho assinada. Assim, conforme Santos:

[...] sendo os benefícios previdenciários devidos aos cidadãos por via da regulação profissional, e sendo a contribuição de cada um função de seu nível de renda, a regulação da cidadania implicou, na prática, em uma discriminação na distribuição dos benefícios previdenciários na mesma medida em que quem mais podia contribuir, maiores e melhores benefícios podiam demandar. A universalidade aparente da lei em sua partição profissional convertia-se em desigualdades entre os cidadãos via sistema previdenciário (SANTOS, 1979, p. 77).

Como já abordado nesta tese, é evidente, nessa valorização, o cultivo da estrita relação entre trabalho, principalmente o assalariado ou remunerado, e políticas sociais. Hoje é muito difundido pelo neoliberalismo que o mercado é de acesso a todos; porém, cada um é responsável em conquistar seu bem-estar. Todavia, como afirma Pereira (2010), inspirada em Fagnani (2005) e em SANTOS (1979), "a inserção no mercado de trabalho formal ou com carteira assinada, tornou-se, no País, um divisor de águas entre a cidadania e a marginalidade cívica" (PEREIRA, 2010, p.13). Contra essa tendência, vale recorrer ao seguinte pensamento de Marshall (1950 apud BARBALET, 1989, p. 17):

À medida que o capitalismo evolui como sistema social e a estrutura de classe se desenvolve dentro dele, também a cidadania moderna passa de um sistema de direitos que nasce das relações de mercado e as apoiam para um sistema de direitos antagônico com os sistemas de mercado e de classe.

Assim, se todas as pessoas são iguais perante a lei em uma estrutura social, devendo exercer seus direitos de cidadãos, grupos particulares não devem ter mais e melhor atenção que outros. O exercício da cidadania não deve ter divisões de classes ou de qualquer natureza. A carteira assinada como instrumento de regulação do status de cidadania limita o contingente de beneficiários de políticas públicas. Tal distorção foi definida por Santos de cidadania regulada porque suas raízes: 
[...] encontram-se, não em um código de valores políticos, mas em um sistema de estratificação, e que, ademais, tal sistema de estratificação ocupacional é definido como norma legal. Em outras palavras, são cidadãos todos aqueles membros da comunidade que encontram localizadas em qualquer uma das ocupações reconhecidas e definidas por lei (SANTOS, 1979, p. 75).

Mas, gradativamente, a Política Social foi ampliando o seu escopo e considerando novas necessidades sociais. Em 1973, por meio da Portaria no 3.286, o Ministério do Trabalho e Previdência Social, regulamentou a aposentadoria por velhice, instituindo como beneficiário o segurado com 65 anos e mais de idade para o homem e 60 anos ou mais para as mulheres. E, em1974, o Ministério da Previdência e Assistência Social - MPAS foi criado pela Lei $n^{\circ} 6.062$, de 25 de junho, com a função de promover a maximização da equidade na sociedade brasileira.

Com a Lei ํo 6.179, de 11 de dezembro de 1974, instituiu-se o amparo previdenciário às pessoas maiores de setenta anos, incapacitados para o trabalho, sem exercer atividades remuneradas e que tivessem sido filiados ao INPS pelo menos 12 meses consecutivos, ou ainda, tivessem ingressado no regime do INPS após completar 60 anos de idade. 0 benefício chamado de Renda Mensal Vitalícia não ultrapassava $60 \%$ do salário mínimo.

Uma das medidas do Ministério da Previdência e Assistência Social - MPAS foi implantar o Programa de Pronta Ação - PPA, estipulando regras para prestação de serviços médicos e previdenciários. O Programa oferecia também atendimento emergencial gratuito aos segurados ou não da Previdência Social e o Estado sinalizava a universalização do sistema público.

Em 4 de julho de 1974, o MPAS editou a Portaria ํㅜ 82, ampliando a proteção social ao segurado idoso, além da assistência prestada em hospitais e ambulatórios de forma indireta ou por intermédio de convênios. O Ato propunha ainda atividades a serem programadas, enfatizava a importância do trabalho preventivo com ações motivadoras na comunidade e disciplinava condições para internação.

Em 1975, o Instituto Nacional de Previdência Social - INPS unificou e uniformizou as prestações de benefícios e serviços aos trabalhadores integrados no mercado formal urbano. O IPASE foi responsável por prestar benefícios e serviços aos servidores públicos dos Estados, cobrindo uma categoria especifica de servidores públicos.

Considerando-se somente a legislação previdenciária constituída pelo sistema INPS IPASE e FUNRURAL, é possível verificar a grande cobertura da população por algum tipo de proteção. Os benefícios do INPS cobriam, nessa época, aposentadorias por invalidez, velhice ou tempo de serviço, além de pensões e auxílios diversos (como natalidade, doença, 
reclusão, funeral, tratamento fora do domicílio e exame médico pericial também fora do domicílio), abonos, pecúlios, salário-família, salário-maternidade e acidente de trabalho.

Até 1978, o Ministério da Previdência e Assistência Social se reorganizara em agências de previdência e assistência médica, em função da Lei $n^{\circ} 6.439$, de 2 de setembro de 1977, criando o Sistema Nacional de Previdência e Assistência Social -SINPAS, voltado para: a universalização do atendimento médico com a implantação do Plano de Ações Integradas de Saúde; a concessão e a manutenção de benefícios; a prestação de serviços; o custeio de atividade e programas; a gestão administrativa, financeira e patrimonial da Previdência e Assistência Social. Para cumprir essa missão, foram criados o Instituto Nacional de Assistência Médica da Previdência Social - INAMPS, o Instituto de Administração Financeira da Previdência e Assistência Social - IAPAS, o INPS, a Central de Medicamentos - CEME, a Legião Brasileira de Assistência - LBA, a Empresa de Processamentos de Dados da Previdência Social - DATAPREV e a Fundação Nacional do Bem-estar do Menor - FUNABEM.

O governo, preocupado com a questão do envelhecimento no país, realizou, em 1976, por intermédio do Ministério da Previdência e Assistência Social, três seminários regionais (em São Paulo, Belo Horizonte e Fortaleza), com o objetivo de identificar as condições de vida da pessoa idosa. Em seguida a esses seminários, realizou-se no mesmo ano, em Brasília, um seminário nacional, com o tema "Política Social da Velhice", originando, com base nas suas conclusões, o documento "Política Social para o Idoso: diretrizes básicas", editado pelo Ministério da Previdência e Assistência Social, do qual resultaram as seguintes propostas:

- Implantação de sistema de mobilização comunitária, visando, dentre outros projetos, a manutenção do idoso na família;

- Revisão dos critérios para concessão de subvenção para as entidades de longa permanência para idosos, os antigos asilos;

- $\quad$ Criação de serviços médicos especializados para a pessoa idosa, incluindo atendimento domiciliar;

- Revisão do sistema previdenciário e preparação para aposentadoria;

- $\quad$ Formação de recursos humanos;

- $\quad$ Coleta de dados e informações sobre a situação da pessoa idosa pelo Serviço de Processamento de Dados da Previdência e Assistência Social - Dataprev, em articulação com a Fundação Instituto Brasileiro de Geografia e Estatística, dentre outros. 
Com o Decreto no 94.657, de junho de 1987, muitas das deliberações da VIII Conferência Nacional de Saúde foram colocadas em prática, tornando-se universal o atendimento médico e desaparecendo a distinção entre segurado e não segurado da Previdência e o privilegiamento da rede pública.

Segundo a Associação Nacional de Gerontologia (1989), embora 1976 tenha sido um marco na mobilização, nas discussões e na elaboração de propostas para a velhice, pouco ou quase nada foi implantado no curso de quinze anos.

O governo federal, visando dar respostas às demandas sociais do país, propôs reformulações nas ações do MPAS, definindo áreas específicas de atendimento. Com essas providências, coube à então Fundação Legião Brasileira de Assistência Social - LBA a responsabilidade de desenvolver todos os programas assistenciais, dentre eles, o de assistência à pessoa idosa. Antes, esse programa estava sob a responsabilidade do Instituto Nacional de Previdência Social - INPS, instituído pela Portaria 838/77.

A LBA passou a executar a Política Nacional de Apoio ao Idoso em suas próprias unidades executoras, via ação comunitária e, de forma indireta, por intermédio de convênios e contratos com entidades governamentais especializadas. As ações eram realizadas por meio dos projetos "Conviver" e "Asilar," que cobriram em torno de 1.200 entidades e 2.600 municípios. Para sua execução, eram repassados às instituições valores per capita pelos serviços prestados e, ainda, por meio de convênios de cooperação técnica e financeira e/ou repasse de recursos para revitalização e construção de equipamentos da rede pública e privada.

Entretanto, com a promulgação da Constituição Federal de 1988, conhecida como Constituição cidadã, novas normatizações entraram em cena. Pela primeira vez na História política do País, uma Constituição da República Federativa do Brasil contemplou um Sistema de Seguridade Social, composto pelas políticas de Previdência, Saúde e Assistência Social. Esta também foi reconhecida como política pública que deveria concretizar direitos sociais de caráter assistencial, assumindo, assim, um status legal diferente das ações assistências realizadas pela LBA, que foi extinta em 1995. Os artigos 203 e 204 da Carta Magna de 1988 garantiram à pessoa idosa um sistema de proteção social de acordo com as diretrizes emanadas das normativas internacionais. Foi a partir desse momento histórico que o Brasil não só passou a participar com maior regularidade das discussões internacionais sobre a temática do envelhecimento, como também passou a levar em conta as normativas produzidas com base nessas discussões.

Com efeito, a partir da Constituição de 1988, foram criadas as regras mais específicas, visando proteger os direitos dos segurados da Previdência Social, incluindo evidentemente o 
idoso, e as normas gerais de contabilidade, com o intuito de garantir o equilíbrio financeiro atuarial dos servidores públicos da União, dos Estados, dos municípios, dos militares dos Estados e do Distrito Federal.

O regime que protege a maior parte dos trabalhadores no país é o Regime Geral de Previdência Social - RGPS, o qual cobre os trabalhadores assalariados urbanos, autônomos, domésticos e rurais. Trata-se da Previdência dos trabalhadores da iniciativa privada e dos servidores públicos regidos pela Consolidação das Leis do Trabalho - CLT. De acordo com os dados do Ministério da Previdência Social (2012), existem cerca de 56 milhões de contribuintes, sendo este um dos mecanismos de proteção social mais efetivo no País. A Previdência Rural é contributiva por natureza, isto é, possui uma forma de contribuição diferenciada da urbana e adaptada à condição de vida no campo, a saber: é realizada de acordo com a produção comercializada, sendo $2,6 \%$ para pessoa jurídica e $2,1 \%$ para pessoa física.

A Lei Orgânica da Assistência Social, Lei no 8.742/1993, que regulamenta os artigos 203 e 204 da Constituição Federal vigente - e foi aprovada após vetos presidenciais e amplas mobilizações sociais -, prevê benefícios, programas e projetos destinados à população idosa, como o Benefício de Prestação Continuada (BPC), de caráter não contributivo. Mas, esse benefício em dinheiro, no valor de um salário mínimo mensal transferido pelo governo federal às pessoas idosas com 65 anos ou mais de idade com renda per capita familiar de $1 / 4$ do salário mínimo, revela-se focalizado na pobreza externa, em consonância com os preceitos neoliberais.

Com o objetivo de promover a autonomia, a integração e a participação efetiva do idoso na sociedade, foi sancionada a Lei no 8.842/94, instituindo a Política Nacional do Idoso. E para regular os direitos assegurados às pessoas com 60 anos e mais de idade, foi sancionada a Lei no 10.741/2003, que instituiu o Estatuto do Idoso. Essa lei foi fruto dos movimentos sociais de base em prol da ampliação dos mecanismos de proteção e de defesa dos direitos da pessoa idosa.

Com a extinção da Legião Brasileira de Assistência, as políticas assistenciais destinadas à pessoa idosa passaram a ser coordenadas pela Secretaria de Assistência Social, vinculada ao Ministério da Previdência e Assistência Social.

Contudo em 2003, foi criado o Ministério do Desenvolvimento Social e Combate a Fome (MDS), ao qual coube a coordenação tanto da Política de Assistência Social como da Política Nacional do Idoso. Entretanto, sob o Decreto n 6.800/2009, a coordenação da Política Nacional do Idoso foi atribuída à Secretaria Especial de Direitos Humanos da Presidência da República. 
Como bem definido nos documentos internacionais e nacionais, a importância da proteção às pessoas idosas com programas, projetos e serviços, tanto para estimulação do envelhecimento ativo quanto para assistir pessoas em situação de dependência, é inegável, destacando-se os cuidados de longa duração.

O Estatuto do Idoso veio a regular os direitos às pessoas com 60 e mais anos de idade previstos nos ordenamentos legais. Essa é uma lei que também se pautou pelas orientações do II Plano Internacional para o Envelhecimento, resultante da II Assembleia Mundial do Envelhecimento, realizada em Madrid, em 2002, pela Organização das Nações Unidas.

Os movimentos sociais em favor das pessoas idosas são importantes para somar esforços no sentido de fazer com que as leis saiam do papel ou não se transformem em letra morta. Já faz 20 e 11 anos que a Política do Idoso e o Estatuto do Idoso foram, respectivamente, sancionados; mas pouco se avançou em relação à implementação de serviços e, enquanto isso, a cada ano, a população idosa cresce de forma irreversível. Se o Estado é democrático de direitos, todos têm direito a ter direitos.

À guisa de síntese crítica da trajetória recente da política social voltada para as pessoas idosas no Brasil e do envolvimento tanto do Estado quanto da sociedade nesse processo, apresentam-se, a seguir, na íntegra, cinco depoimentos feitos por idosos que vivenciaram aspectos diferenciados dessa realidade sem perderem a visão de conjunto.

Depoimento 1, de Marcelo Antônio Salgado, Especialista em Gerontologia e Epidemiologia do Envelhecimento (Região Sudeste):

Nos anos 70, aconteceram as primeiras ações de definição de uma política social para idosos na sociedade brasileira, a partir do esforço de algumas instituições não governamentais, profissionais e voluntários que já se dedicavam a um trabalho de atenção aos idosos.

Com a criação do Ministério da Previdência Social e Assistência Social, ainda no Governo militar, a questão da velhice foi incorporada ao rol das políticas públicas, ainda que sofrendo resistência de muitos setores governamentais e grupos de profissionais que não reconheciam a evidência dessa nova questão social. Mesmo assim, por iniciativa da Secretaria de Assistência Social daquele ministério e sob a nossa orientação, aconteceu a primeira mobilização de que se tem notícia para a formulação de um diagnóstico sobre a questão da velhice na sociedade brasileira, recursos e programas de atendimento. Foram realizados três seminários regionais (regiões Sul/Sudeste, Norte/Nordeste e Centro-Oeste) para estudo e diagnóstico, e um seminário Nacional que elaborou as bases da primeira política social para velhice. Nesse movimento, destaca-se a participação do SESC - São 
Paulo, INPS e LBA (nacionais e regionais). Não menos expressiva foi a colaboração de inúmeras instituições, universidades e outros movimentos sociais de todas as regiões do País.

Os anos seguintes foram ricos em ações e políticas, destacando-se os programas de capacitação em Gerontologia social, os inúmeros seminários realizados (inclusive os eventos da SBGG), a criação do benefício da Renda Mensal Vitalícia, o surgimento de instituições de defesa do idoso (Mopi, Acepi, Assipa e outras), os diversos eventos de estudo realizados pelo SESC (Nacional e Regionais). As ações e programas para idosos proliferaram: centros de convivência, grupos de idosos, escolas abertas, programas de preparação para aposentadoria e muitos outros.

Nas décadas seguintes, os estudos sobre os diversos aspectos socioeconômicos sobre a questão da velhice se avolumara Proliferaram os programas e atividades para idosos, os conselhos de direitos e foram elaborados regulamentos e leis (Lei 8.842 e Estatuto do Idoso) que ampliaram as intenções de políticas sociais para esse segmento etário, porém com poucos resultados em ações efetivas.

A questão da velhice passou a ter muita visibilidade. Hoje os idosos são reconhecidos como um grupo etário sujeito a necessidades que implicam ações particulares. Entretanto, parece não serem reconhecidos como grupo social, visto não usufruírem de alguns direitos elementares de cidadania, como renda digna, assistência médica adequada, segurança, e muitas outras condições que promovem a qualidade de vida.

Mesmo reconhecendo a qualidade de programas e serviços mantidos em algumas cidades de diferentes regiões do País, no que diz respeito à política social para velhice, [esta]cresceu no discurso mas estancou na prática. Em alguns casos, recuou, sobretudo quando se trata de questões referentes à pobreza econômica e seguridade social. Reconhecer direitos não basta, pois é necessário proporcioná-los.

O futuro é preocupante, especialmente em tempos de crise econômica e social. O achatamento progressivo do valor das aposentadorias e a crescente inflação, geram nos cidadãos a perspectiva da perda da independência econômica e a dependência dos filhos adultos ou de outros. As dificuldades de acesso ao atendimento à saúde, a violência, os preconceitos, as reduzidas oportunidades de participação social, fazem do tempo da velhice um tempo de constrangimento e isolamento social. O envelhecimento não pode significar a 
morte social, resultando que muitos idosos se apresentem como um corpo estranho de indivíduos em nossa sociedade. ${ }^{11}$

Depoimento 2, de Edusa Pereira, militante dos direitos humanos no Estado de Pernambuco, conselheira do Conselho Estadual do Idoso (Região Nordeste):

Finda a ditadura, a primeira referência aos direitos humanos constou da nossa Constituição Cidadã, em 1988 (40 anos depois de instituída).

Com o advento da democracia, aqueles que fizeram oposição à ditadura passaram à defesa dos direitos humanos, em uma das faixas com as quais mais se identificavam (mulher, crianças, idosos, presos, etc...). Estando eu com 57 anos, o mais lógico era a escolha da defesa dos direitos do idoso.

Daí, passamos a criar grupos de estudos, que se reuniam mensalmente. Havia relativamente poucos idosos, pois a média de vida do Brasil, em 1980, era de 62,7 anos, além da acentuada discriminação, pois o idoso era sinônimo de doente, inativo, descartável. A sociedade se retraía ao abordarmos a questão do envelhecimento. E não foi fácil reverter isto.

Mas, com o aumento acelerado do número de idosos e os avanços na área da medicina, que garantiam mais saúde nos anos que foram agregados às nossas vidas, avançamos, conquistando, em 1994, a aprovação da Lei no 8.842 - Política Nacional do Idoso, regulamentada em 1996.

Daí, passamos a instituir Conselhos de Direitos, a realizar Conferências e a debater a elaboração do Estatuto do Idoso.

No início, a discussão política se apoiou nas Associações dos Aposentados, que tinham uma maior defesa dos direitos dos trabalhadores, mas eram, pelo menos, grandes grupos de idosos já organizados.

Ao chegarmos ao Estatuto, realizamos manifestos, caminhadas, cartas aos legisladores, tudo que pudesse influir na opinião pública. Fizemos reuniões nas capitais dos Estados e promovemos encontros nacionais. Tudo com recursos pessoais - passagens, diárias e materiais.

\footnotetext{
${ }^{11}$ Marcelo foi quem iniciou o trabalho com idosos no Brasil há quase 50 anos. O seu depoimento como idoso e especialista da área do envelhecimento revela as fragilidades das políticas que não são efetivadas, o tema não está na agenda política dos gestores nas três esferas de Governo, sendo simplesmente desanimador o quadro da Política do Idoso no Brasil.
} 
A primeira proposta do Deputado Paulo Paim foi em 1997, mas sua aprovação só foi alcançada em 2003 - vejam quanto tempo!

A partir daí, temos lutado para que as Políticas Públicas saiam do papel e o envelhecimento seja verdadeiramente protegido no Brasil.

No entanto, faz-se necessário mobilizar os idosos e a SOCIEDADE EM GERAL para impulsionar a lei escrita e convertê-la em realidade.

O idoso independente precisa ser "protagonista" dos seus direitos. Mas isso não é fácil culturalmente: esses idosos, quando crianças, tiveram uma educação doméstica repressora; o ensino básico não era obrigatório; carão de mãe era "rabo de olho"; ninguém contestava um pai; tiveram sua juventude no período da ditadura; direitos humanos já os alcançaram na fase adulta e até na velhice. Apesar dos avanços sociais, reverter essa configuração é difícil.

O idoso dependente precisa do auxílio da família. E a família precisa de uma rede de apoio e políticas públicas que Ihes possibilite viver sem sacrifício, com o conforto de assistirem seus idosos viverem suas velhices com dignidade. Atualmente, as famílias são de pequeno porte e as avós já estão ocupadas com os netos, cujas mães estão trabalhando fora de casa. E não há cuidadores. O Governo não tem tido sensibilidade para dar a esses idosos o devido apoio - na realidade, a saúde em geral, no Brasil, está desassistida.

Nos parece, no entanto, que a sociedade, embora recentemente tenha demonstrado alguma receptividade para a inclusão do idoso independente, ela ainda permanece com o antigo preconceito em relação ao idoso dependente: doente, improdutivo, incapaz, oneroso, descartável.

Embora nos debates políticos não tenhamos nenhuma referência às necessidades das pessoas idosas, a nossa luta pela conscientização de toda a sociedade continua. ISTO É O QUE IMPORTA.

Depoimento 3, de Vitória Góis de Araujo, servidora pública aposentada, exconselheira do Conselho Nacional dos Direitos do Idoso e ex-participante da coordenação da Política Nacional do Idoso (Região Centro-Oeste):

Considerando o Brasil como um país relativamente jovem, a questão do envelhecimento só passou a fazer parte do cenário político brasileiro, embora que de maneira tímida, a partir da década de 70, com a realização do 1 Seminário Nacional sobre o Envelhecimento, em 1976, em Brasília, promovido pelo então Ministério da Previdência e Assistência Social. A partir desse marco, outras iniciativas ocorreram, de forma não sistemática e esporadicamente, em outros Estados. 
Hoje, no Brasil, são inúmeras as leis que dão ampla cobertura à população idosa. Essas conquistas foram frutos, na sua maioria, da mobilização da sociedade civil organizada, destacando os direitos assegurados na Constituição Federal de 1988, conhecida como Constituição Cidadã pela grande abertura política e participação da sociedade.

A década de 90 foi marcada pelas discussões e debates com vistas à criação de uma Política Nacional que atendesse aos anseios e demandas da população idosa. Assim, em 1994, foi criada a Política Nacional do Idoso, PNI, Lei no 8.842/94, se constituindo em um grande marco na área do direito e garantia da cidadania dos idosos. Assegura direitos sociais, promovendo a autonomia, integração e participação efetiva da pessoa idosa na sociedade. No entanto, todos os artigos referentes ao conselho foram vetados na sua íntegra, vindo somente a ser criado em 2002, o Decreto no 4.227, de 13 de maio de 2002, posteriormente foi editado o Decreto $n^{\circ}$ 5.109, dando paridade ao referido Conselho.

O Conselho Nacional dos Direitos do Idoso - CNDI, que, em maio de 2012, fez 10 anos de existência, tem uma história, cuja criação se deu a partir das lutas empreendidas pelas instituições organizadas da sociedade civil, como as associações, movimentos sociais, e em decorrência da Segunda Assembleia Mundial do Envelhecimento, realizada em Madri, em 2002, que gerou uma sensibilização do governo brasileiro.

Apesar da existência de legislação desde 1994, como a Política Nacional do Idoso, Lei $n^{\circ}$ 8.842/94, e Decreto no 1.948/96, foi com o Estatuto do Idoso, Lei no 10.741/2003, que ações efetivas e concretas foram determinantes e organizadas no combate à violência contra a pessoa idosa, que até então eram negligenciadas pelos órgãos competentes. $O$ Estatuto do ldoso assinala que o idoso goza de todos os direitos fundamentais inerentes à pessoa humana, e que o envelhecimento é um direito personalíssimo e a sua proteção um direito social (art. $2^{\circ}$ e art. $8^{\circ}$ ), cabendo ao Estado a respectiva proteção quando os direitos reconhecidos na Lei forem ameaçados ou violados (art. 43).

Vimos que, em termos de legislação, o Brasil está muito bem aparelhado, inclusive à frente dos demais países da América do Sul, no entanto, a grande maioria da população idosa sofre de negligência institucional pública, familiar e social. Este segmento foi o único que não conseguiu até então sua Agenda Social, com metas e recursos adequados para enfrentar e atender às suas necessidades e garantir a sua qualidade de vida.

Enquanto conselheira do CNDI, por duas gestões, representando a sociedade civil, o que se observa é uma correlação de força e de poder, entre os representantes da sociedade civil e do governo. O Estado instrumentaliza a gestão pública com mecanismos de participação, tais como: Conselhos, Conferências Nacional, Estaduais, Municipais e do 
Distrito Federal, Reuniões Descentralizadas, Audiências Públicas. Entretanto, não materializa as demandas apresentadas pelas pessoas idosas, nem em serviços nem em financiamentos previstos na legislação em vigor, para reestruturação da Rede Nacional de Promoção e Defesa das Pessoas Idosas. Para reestruturação dessa Rede, a legislação garante modalidades de serviços, programas e projetos que deveriam integrar uma Política de Cuidado. Podemos mencionar a necessidade de modernizar as Instituições de Longa Permanência, ILPI's, Centro Dia, Residência Temporária, Assistência Domiciliar, Trabalho com as Famílias, dentre outras. Estas ações deveriam garantir a integração das Políticas Públicas previstas na PNI e no Estatuto do Idoso, no entanto, não são previstos recursos financeiros e nem recursos humanos. Cabe citar, ainda, que não bastasse a legislação já existente, o Governo Federal - Secretaria de Direitos Humanos da Presidência da República - SDH, instituiu o Compromisso Nacional para o Envelhecimento Ativo. Este documento, que conta com a adesão de 17 (dezessete) órgãos governamentais, não conta com metas e financiamento para atender as demandas das pessoas idosas explicitadas nas 3 (três) Conferências Nacionais realizadas em Brasília, nos anos de 2006, 2009 e 2012.

Como conselheira, posso dizer, que a participação social realizada pelas pessoas idosas e representantes de movimentos sociais se caracteriza por uma cidadania regulada, uma vez que o Poder Executivo investe em ouvir a sociedade civil e posteriormente não viabiliza suas necessidades e não leva em consideração suas propostas para a melhoria da qualidade de vida das pessoas idosas e das famílias.

Por fim, vale ressaltar que o Estatuto do Idoso avançou nos direitos, entretanto, as Políticas Públicas não conseguem se integra, e nem oferecem serviços de qualidade que atendam às necessidades da população idosa, previstas na PNI e no Estatuto do Idoso.

Depoimento 4, de Emídio Rebelo Filho, aposentado e militante de movimentos sociais em prol da pessoa idosa (Região Norte):

A nossa participação no movimento para a implementação de uma política própria que trouxesse resultados positivos às pessoas idosas teve início ainda na década de 80 , precisamente no segundo semestre de 1986, quando fomos convidados a ingressar na Comissão dos Direitos do Idoso de Belém - CODDIBE, reunindo diversas associações e grupos ainda sem uma estrutura que pudesse, com segurança, avançar nas reivindicações necessárias e pertinentes ao atendimento desse segmento que estava desprovido de qualquer garantia de direitos. Reuniões periódicas dessa Comissão foram se tornando o ápice para o fortalecimento de se alcançar o reconhecimento da sociedade e do governo, surgindo a feliz ideia de congregar todos os movimentos existentes no Estado do Pará, principalmente na capital, em um único organismo representativo. Daí, fixou-se na fundação 
da Federação das Associações de Aposentados e Pensionistas do Estado do Pará FAAPPA, filiada à Confederação Brasileira de Aposentados e Pensionistas - COBAP, criada em 24 de setembro de 1992. Assumimos a presidência para um mandato com a duração de um ano, culminando com recondução para um período de mais dois anos. Outros mandatos, intercalados, foram assumidos no período de 1996 a 2014. E assim, em mais de vinte anos de existência da Federação, continuamos com a participação em todos os movimentos que buscam a melhoria da qualidade de vida das pessoas idosas, dos aposentados e pensionistas, destacando-se a participação nos eventos, com:o encontros, seminários, congressos, conferências e fóruns, que se reúnam para discutir o realizado e o que se tem por realizar no presente e futuro. Um outro destaque de importância vital para o processo organizativo das pessoas idosas está na colaboração e participação efetiva da instalação dos Conselhos Municipais, Estadual e Nacional, representando o segmento, com o objetivo de assegurar o pleno cumprimento do estabelecido na Constituição Federal, com os direitos fundamentais do cidadão e nas Leis Complementares no 8.842/1994 (Política Nacional do Idoso) e 10.741/2003 (Estatuto do Idoso). Convém ressaltar a participação no Conselho Nacional de Previdência Social - CNPS e no Conselho Nacional dos Direitos do Idoso CNDI, representando como titular a Federação das Associações de Aposentados e Pensionistas do Estado do Pará - FAAPPA; Associação de Mantenedores - Beneficiários da Petros - AMBEP; Confederação Brasileira de Aposentados e Pensionistas - COBAP (dois mandatos); Ordem dos Advogados do Brasil (dois mandatos) e, na direção da FAAPPA, a coordenação e a realização de nove Congressos Estaduais com os seguintes temas: I - Anteprojeto do Estatuto do Idoso; II - Saúde do Idoso; III - Gerontologia Social e Geriatria em todos os Níveis da Educação Brasileira; IV - Formação e/ou Capacitação de Recursos Humanos em Gerontologia e Geriatria: V - O Idoso e o Transporte Coletivo no Estado do Pará; VI - Nutrição: Ação Decisiva à Vida Saudável da Pessoa Idosa; VII Previdência Social; VIII - O Envelhecimento e a Expectativa para o Futuro; IX - A Importância da Sociedade Civil Organizada: O papel das Associações de Aposentados e Pensionistas em todos os Municípios do Estado.

Depoimento 5, Sérgio Antonio Carlos, Chefe do Departamento de Serviço Social da Universidade Federal do Rio Grande do Sul e editor da Revista Interdisciplinares sobre Envelhecimento:

Em 1992, retornei da minha licença para o Doutorado. E retornando para a UFRGS, fui pressionado a assumir a coordenação da Universidade da Terceira Idade (UNITI) - projeto de extensão do Instituto de Psicologia, já que a criadora e coordenadora havia se aposentado. Embora a professora continuasse a trabalhar no projeto, era necessário que um professor não aposentado respondesse pela coordenação. Iniciou-se um trabalho junto 
aos estagiários e bolsistas que desenvolviam atividades na UNITI, ao mesmo tempo em que me aproximava do então Núcleo da Terceira Idade organizado pela PROREXT, que depois passou a se denominar Núcleo de Estudos Interdisciplinares sobre o Envelhecimento, coordenando-o diversas vezes. Vinculado ao Núcleo, representei a UFRGS, juntamente com a professora Vera Waldow, de 1995 a 1998, no projeto de pesquisa Idosos Urbanos do Rio Grande do Sul, realizado por catorze universidades do Estado do Rio Grande do Sul e coordenado pelo Conselho Estadual do Idoso (CEI). Participamos de todas as fases da pesquisa, mas principalmente da capacitação de supervisores de campo e da fase de relatório, desenvolvida a partir de processamento dos dados feito pela Universidade Católica de Pelotas. Como subproduto, foi produzido um relatório pelos representantes das Universidades da Região Metropolitana, denominado ldosos Urbanos Aposentados na Região Metropolitana de Porto Alegre. Foi produzido pelos pesquisadores da UFRGS, PUCRS, UNISINOS e ULBRA e foi publicado pelo CEDOP - UNISINOS em 1999.

Ainda relacionado à temática do envelhecimento, representei a UFRGS no Conselho Estadual do Idoso (CEI) como conselheiro titular de 1998 a 2002, tendo sido eleito como Diretor-Presidente para o período de 2000 a 2002. Foi um período de bastante efervescência. Tivemos a aprovação da Política Estadual do Idoso, discussões e aprovação do Estatuto do Idoso e a realização da I Conferência Estadual do Idoso em 2001. Em todas essas atividades, não só estive presente como também tive atuação destacada.

Representei o CEI no Seminário junto à Câmara de Deputados, que levou a algumas alterações do projeto, sendo uma das mais importantes a penalização. Participei também de diversos encontros junto a diversos Ministérios para a discussão de projetos e políticas voltadas para os idosos, inclusive a revisão de uma sistematização de programas de atendimentos a idosos, que subsidiou a ANVISA para a elaboração da norma sobre ILPIs. Na região Sul, participei de várias reuniões do Fórum para implantação da Política do Idoso, reunindo representações governamentais, não governamentais e Conselhos Estaduais dos Estados do Paraná, Santa Catarina e Rio Grande do Sul. Nestes fóruns, foram realizadas muitas trocas de experiências de trabalhos com idosos, avaliadas ações comuns (como a campanha de vacinação) e estabelecidas estratégias de relação com o governo federal.

Em nível estadual, participei da elaboração das diretrizes para a política estadual do idoso (elaborada pelo CEl, bem como a realização da primeira Conferência Estadual do Idoso em 2001). Foi a primeira Conferência do Idoso no Brasil. Participei também das discussões com outros conselhos estaduais para a criação do Conselho Nacional do Idoso.

Até os dias atuais, continuo a ser convidado para proferir palestras, participar de mesas redondas ou coordenar plenárias. Entendo que muito se deve à minha participação 
no Conselho Estadual do Idoso, mas também pelo trabalho que desenvolvo na UFRGS sobre a temática e minha relação com a Sociedade Brasileira de Geriatria e Gerontologia/RS.

Também inspirou a realização de outras pesquisas sobre o tema, como o projeto Identidade, aposentadoria e terceira idade, desenvolvido sob minha coordenação e da professora Maria da Graça Correa Jacques, que recebeu auxílio do CNPq. Para a publicação dos resultados desta pesquisa, iniciamos a publicação de um periódico que denominamos de Estudos Interdisciplinares sobre o Envelhecimento, cujo primeiro volume foi publicado em 1999. Sou o editor da revista desde 1999 até a presente data. Foram publicados 24 números e mais dois já estão prontos para serem publicados ainda em 2014, ano em que o periódico passou a ter a periodicidade de três números anuais. A revista hoje é classificada como Qualis B1 na área interdisciplinar e B2 na área de Educação Física, Fonoaudiologia, Terapia Ocupacional e Fisioterapia. A revista tem um reconhecimento pelos pesquisadores nacionais e internacionais da área do envelhecimento, que pode ser verificado pelos avaliadores "ad hoc", pela quantidade de artigos submetidos e também pelas citações dos artigos publicados, tanto em outras publicações quanto em teses e dissertações.

$\mathrm{Na}$ relação com o envelhecimento, é preciso ressaltar que trabalhei em algumas frentes: uma foi a de dar visibilidade à minoria masculina, outra foi a de discutir e defender que a representação nos conselhos estaduais e municipais não é uma atividade individual, mas precisa ser a de um porta-voz de um grupo ou de um segmento. Outros pontos que têm a ver com essas frentes dizem respeito a pensar o processo de aposentadoria e o desligamento do trabalho, as políticas para a população idosa e a impossibilidade de idosos dependentes poderem estar em mobilizações reivindicando suas necessidades. Penso que o envelhecimento é multidimensional, isto é, precisamos pensar em envelhecimentos, em idosos, com um leque grande de matizes que vão desde pessoas envelhecendo e velhos bastante ativos, reivindicativos e participantes até uma gama de pessoas dependentes, demenciadas ou não, que necessitam de auxílio não só para decisões políticas, mas para decisões no seu dia a dia.

O Brasil tem uma legislação avançada em relação à temática. Além do Estatuto do Idoso, deve-se ressaltar a Política Nacional do Idoso (PNI), anterior ao mesmo. O grande problema é a implementação desta Política e de ações concretas. Sabe-se que a PNI previa a existência de uma Coordenação Nacional da Política que trabalhasse na articulação de ações dos diversos ministérios. Não se pode dizer que não tenha existido. Existiu, mas quase sempre dependendo mais da intenção das pessoas responsáveis por esta articulação do que de uma ação institucional. Dá a impressão de que os governos ainda não se deram 
conta da prioridade das questões do idoso e do envelhecimento. Pode-se exemplificar com a realização das Conferências Nacionais: a primeira em maio de 2006, a segunda em março de 2009, a terceira em novembro de 2011 e a quarta prevista para outubro de 2015, onde somente entre a segunda e a terceira foram respeitados os dois anos de intervalo. Outro aspecto que se deve questionar é o destino das deliberações das Conferências que deveriam servir para correção de rumos da Política do Idoso e dos projetos e ações, o que levaria a uma continuidade independente de governo. O que se vê é que não existe uma política de Estado para a população idosa que seja assumida por cada um dos governos que tem-se sucedido.

Por fim, neste capítulo, cabe fazer referência a um ganho institucional significativo: a previsão do controle democrático sobre as legislações e a política do idoso prevista na Constituição Federal vigente.

\subsection{CONTROLE DEMOCRÁTICO COMO INSTRUMENTO DE DEMOCRACIA DIRETA}

Um canal institucional de controle democrático e, portanto, de tramitação direta de pleitos dos idosos, são os Conselhos de Defesa de Direitos existentes em cada esfera territorial de governo (União, Estados-membros, Municípios e Distrito Federal).

O Conselho Nacional dos Direitos do Idoso - CNDI foi criado pelo Decreto ํㅜ 4.227, de 13 de maio de 2002, ainda com caráter consultivo e sem paridade entre sociedade civil e Governo. Entretanto, o Decreto № 4.287, de 27 de junho de 2002, determinou a paridade de representação do Governo e da sociedade na sua composição. A primeira presidência do CNDI coube a uma instituição da sociedade civil - Confederação Nacional dos Bispos do Brasil - CNBB. Mas essa instituição não foi eleita de imediato: decorreram três meses após a posse dos conselheiros para eleição do presidente. Nessa gestão, nem todos os representantes eram de instituições de âmbito nacional.

Um dos temas muito questionado no CNDI era o seu caráter consultivo. Em vista disso, novamente foi editado um novo Decreto ํㅜ 5.109, de 17 de junho de 2004, por meio do qual o referido Conselho passou a ter caráter deliberativo, além de sua composição ser ampliada para vinte e oito membros (quatorze representante da sociedade civil e quatorze do Governo). De acordo com o Regimento Interno do Conselho, a presidência do mesmo deverá ser alternada, sendo um mandato da sociedade civil e o outro do governo. Dentre as deliberações do CNDI, destaca-se a realização da I Conferência Nacional dos Direitos da Pessoa Idosa, com o tema "Construindo a Rede de Proteção e Defesa da Pessoa Idosa". 
Os Conselhos Deliberativos do Idoso, assim como os Conselhos congêneres, são espaços políticos menos burocratizados: a participação, a articulação e as ações que Ihes dizem respeito são discutidas entre Governo e sociedade, visando o interesse público. A partir do momento em que passou a ser um órgão deliberativo, o Conselho Nacional dos Direitos do Idoso tem avançado muito no processo de construção da gestão participativa e democrática. Contudo, os Conselhos estaduais e municipais (incluindo o do Distrito Federal) de Defesa de Direitos da Pessoa Idosa, apesar de estarem se fortalecendo e exercendo o seu papel no controle democrático, ainda se ressentem de uma participação mais incisiva da população idosa nesse controle; ou melhor, observa-se um baixo engajamento desse segmento social nos condutos institucionais de controle democrático previstos na Constituição Federal de 1988.

Do mesmo modo, o colegiado do CNDI carece de atuação mais efetiva no processo de tomada de decisões que priorizem interesses legítimos da coletividade por ele representada. Nesse sentido, é preciso repensar o perfil dos conselheiros. Os representantes governamentais devem ser pessoas com maior autonomia de decisão e comprometidas com as demandas e necessidades dos seus representados. Os representantes da sociedade civil, por sua vez, devem buscar interagir entre si na defesa dos interesse de suas bases, evitando uma participação personalista.

No Conselho Nacional de Direitos do Idoso, não há possibilidades de ingerência em assuntos quanto ao controle do destino das verbas públicas dos Ministérios; o Conselho é deliberativo, mas não tem de intervir no orçamento específico da área do idoso nos órgãos públicos com assento no CNDI. A este Conselho é atribuída a gestão do Fundo Nacional do Idoso (FNI), a ele vinculado com base na Lei no 12.213, de 20 de janeiro de 2010, que dispõe sobre esse Fundo e assim define o seu objetivo: financiar os programas e as ações relativas às pessoas idosas com vistas a assegurar os direitos sociais e a criar condições para promover sua autonomia, integração e participação na sociedade.

De acordo com a referida Lei, o FNI deveria funcionar a contento, tal como previsto. No entanto, ele apresenta discrepâncias entre previsão e realização. Como dizia Marx (apud Harvey, 2010) entre direitos iguais, formais, a força decide. É o que acontece com as políticas referentes às pessoas idosas. Enquanto, o envelhecimento populacional não estiver no centro das preocupações políticas, pouco será feito para beneficiá-lo.

Com a criação do FNI, o Conselho Nacional dos Direitos do Idoso passou a ter poderes legais para interferir em assuntos referentes ao financiamento das políticas públicas na área do envelhecimento. $E$ mais, passou a acompanhar a execução orçamentária e financeira do Poder Executivo nacional na área do idoso e de fazer gestões, junto ao Poder 
Legislativo, com o objetivo de garantir verbas nos orçamentos públicos para o desenvolvimento e a ampliação de políticas nessa área.

Nos Conselhos (nacional, estaduais, municipais e do Distrito Federal) do Idoso, é prevista a participação de pessoas idosas nos seus respectivos colegiados, como representantes de instituições de atendimento e defesa de seus direitos. E vários idosos desempenham essa função com apreciável empenho. Importa observar também que há idosos politizados atuando em outros Conselhos, como os de Saúde e de Assistência Social. Muitos deles lutam por políticas mais efetivas nas áreas econômica e social, embora uns e outros apresentem, de quando em vez, certa incredulidade quanto à efetivação das leis, dadas às barreiras que as mesmas encontram para serem colocadas em prática.

De acordo com Pereira (2007):

Os Conselhos [dos idosos] devem pautar-se pelos mesmos princípios, critérios e regras de funcionamento que orientam os demais conselhos gestores previstos na Constituição Federal vigente. Assim, cada conselho, onde quer que esteja situado no âmbito da Federação, constitui um órgão ou instância colegiada, de caráter permanente que, necessariamente, deve:

- Possuir caráter público e não propriamente estatal ou privado. Sendo assim, ele não pode fazer parte da estrutura da Secretaria de Governo, que funcionará como órgão gestor - embora mantenha, com ela, vínculos funcionais -, nem tampouco de instituições particulares;

- Ser instrumento da democracia direta ou semidireta, sem deixar de reconhecer a importância da democracia representativa, e ter, com as instituições $e$ os seus mecanismos, relações recíprocas e complementares;

- Fazer parte de uma cadeia de mecanismos gestores voltada para defesa e atendimento dos direitos dos idosos, a qual incluirá as conferências, os órgãos gestores, os fundos especiais públicos, as entidades privadas e o Ministério Público;

- Reger-se pelos princípios da participação e da descentralização política, administrativa e financeira;

- Exercer o controle democrático das ações governamentais e privadas;

- Zelar pelo comando único da Política do Idoso, em âmbito nacional, estadual e municipal, e dos planos de ação elaborados em cada ente federado, evitando, assim, superposição de comandos e atividades;

- Possuir caráter deliberativo e não só consultivo, e composição paritária;

- Ser um órgão autônomo, imune a influências político-partidárias e a relações de dependência e lealdade, seja com o governo, seja com o setor privado (PEREIRA, 2007, p. 26).

Porém, não obstante, atualmente o CNDI está longe de realizar a democracia direta e participativa como preceitua a Carta Magna, pois a atual gestora da Secretaria de Direitos Humanos (SDH/2013) - a qual o CNDI está vinculado - confunde seu papel, impondo sua vontade, ao eleger como presidente do colegiado o representante da SDH. Essas são distorções que ferem o princípio da democracia participativa, tão ansiada e 
conquistada no período da redemocratização do País, a partir de 1987 com o funcionamento da Assembleia Nacional Constituinte.

Outro exemplo de autoritarismo da Secretaria de Direitos Humanos foi a não realização da IV Conferência Nacional dos Direitos da Pessoa Idosa, que deveria ocorrer em 2014. Em vez disso, a SDH optou por realizar um evento ibero-americano em 2013 na área do envelhecimento e, como o presidente do CNDI era o Subsecretário de Promoção e Defesa dos Direitos Humanos, apenas informou que não havia recursos suficientes para realizar a referida Conferência, ficando evidente o descumprimento por parte do Estado das normas legais que estipulam de dois em dois anos a realização das Conferências nacionais do idoso.

Por ocasião da reunião extraordinária do CNDI realizada em agosto de 2014, um dos representantes da Secretaria de Direitos Humanos - SDH apresentou a proposta inusitada de realização da próxima Conferência Nacional da Pessoa Idosa: que a mesma deveria ser realizada juntamente com a das pessoas com deficiência, crianças e adolescentes, LGBTT e a de direitos humanos, deixando transparecer, na sua exposição, que, mesmo que o colegiado fosse contra, iria prevalecer a decisão do Governo.

Percebe-se, com mais este fato, que a noção de democracia participativa no País está se esvaziando, seja na prática, seja na recusa institucional de lhe conferir legitimidade. E isso não acontece só na área do idoso. No caso dos Conselhos, a sociedade deve se manter atenta para que os mesmos primem pelos seus legítimos papéis e competências legais. É preciso não confundir participação democrática direta com ajuda mútua. Como afirma Dagnino (apud SILVA, 2009, p. 16),

Na década de 1990 [se instituiu no Brasil] outra noção de participação em disputa na atual conjuntura política e social. De acordo com esta autora, a ideia de participação passou por um processo de resignificação, passando a ser vista como "participação solidária". Esta noção de participação relaciona-se com a prática do trabalho voluntário e com a ideia de responsabilidade social de indivíduos e empresas. Neste sentido, há uma despolitização do significado da participação social, pois se enfatiza uma noção de participação individualista, ligada a valores morais, desconectada do coletivo. Esta perspectiva traz impactos negativos tanto para o desenvolvimento e efetivação dos espaços públicos participativos, como para implementação de políticas públicas de combate à pobreza e a desigualdade social.

Os Conselhos se diferenciam pelo grau de envolvimento dos movimentos populares afetos à sua área. Os movimentos na área da Saúde são os mais bem estruturados. protagonismo desses movimentos deu início ao processo de descentralização políticoadministrativa. Os sujeitos da área de Saúde sempre tiveram importante presença no cenário político nacional e têm um histórico de lutas. 
$\mathrm{Na}$ área do envelhecimento, os movimentos mais organizados são os dos aposentados, pensionistas e idosos. As mobilizações realizadas, principalmente sob a liderança da Confederação Brasileira dos Aposentados e Pensionistas, têm mostrado à sociedade a importância da organização das pessoas idosas para que as leis sejam respeitadas e as demandas da coletividade atendidas. Por um lado, as organizações de aposentados têm sido um exemplo para os idosos pouco motivados a lutar por seus direitos; por outro lado, os idosos organizados demonstram maior poder de conquista e de influência. No entanto, muitos dirigentes dessas instituições querem perpetuar-se no poder.

A sociedade precisa se preparar melhor para enfrentar a questão do envelhecimento. O mundo hoje está passando por uma revolução tecnológica e científica, permitindo maior expectativa de vida, e os idosos estão, ainda, necessitando ser mais ativos no exercício de sua cidadania. Uma das reivindicações que precisam estar em pauta são os serviços para as pessoas idosas dependentes, tema este a ser abordado no capítulo seguinte. 


\section{SERVIÇOS DE ATENÇÃO ÀS PESSOAS IDOSAS DEPENDENTES}

O cuidado entra na natureza e na constituição do ser humano. O modo-de-ser cuidado revela de maneira concreta como é o ser humano.

Leonardo Boff

\subsection{SERVIÇOS DESTINADOS AOS CUIDADOS DE LONGA DURAÇÃO NA ESPANHA}

Nos países com maior tradição de proteção social ao idoso, como a Espanha, que possui alta taxa do envelhecimento populacional, existem várias experiências relacionadas aos serviços de atenção às pessoas idosas dependentes. Nas Comunidades Autônomas desse País, começaram a existir, em 1985, serviços como o SAD - Serviço de Ajuda Domiciliar para esse público, principalmente para idosos com dependência moderada. Mas, em uma década (1985-1995), o cenário de demandas e de necessidades relacionadas ao envelhecimento mudou com o aumento do número de pessoas com idade acima de 80 anos e dotadas de acentuados problemas cognitivos. Mudou também o perfil das famílias que tinham a mulher como cuidadora natural e perderam-na para o mercado de trabalho. Acrescenta-se a esse fato a mudança de visão dos profissionais em relação aos cuidados das pessoas idosas dependentes, os quais concluíram que estas necessitavam de um suporte mais qualificado, tanto no âmbito institucional como comunitário.

No bojo dessas mudanças, os Centros Dia ganharam relevância. Eles constituem um lócus onde se desenvolvem uma prática de atenção às pessoas idosas dependentes e um serviço intermediário entre a atenção domiciliar e a instituição de longa permanência. De acordo com Rodriguez Cabrero et al. (2005), o IMSERSO publicou, em 1996, um guia prático sobre Centro Dia para Personas Mayores dependientes. Esse guia foi muito útil para chamar atenção dos responsáveis institucionais para a urgência em se criar em esses Centros, por serem eles um recurso assistencial intermediário ainda escasso. Entretanto, a necessidade urgente de criar esses espaços institucionais visava estimular, sem delongas, a autonomia das pessoas idosas dependentes que viviam em suas casas e, ao mesmo tempo, proporcionar "respiro" (termo equivalente a descanso) do cuidador informal, que, na sua maioria, são as mulheres.

Para Rodriguez Cabrero (2005), os Centros Dia são recursos de natureza social, ainda que incluam uma ampla atenção à saúde e à convivência:

Los objetivos fundamentales son el cuidado de la persona mayor dependiente y desarrollo de su autonomía y, al mismo tiempo, el apoyo a la família cuidadora a la que se libera parcialmente de la carga de cuidado dada la especial naturaleza profesional de los mismos. Es decir, el objetivo 
del Centro de Día es lograr el bienestar y calidad de vida de las personas mayores dependientes y de sus cuidadores informales. El tipo de estructura de cuidados es mixto tanto por la intervención del ámbito social como el sanitario, ya que se trata de cuidados integrales, así como por las funciones amplias que desarrolla: rehabilitadora y asistencial (RODRIGUEZ CABRERO, 2005, p. 9).

A maioria das famílias que possuem idosos dependentes não tem condições de prestar os cuidados que, de fato, requerem equipe interdisciplinar capacitada, por se tratar de um serviço combinado de assistência social e saúde. Logo as ações devem ser desenvolvidas de forma integrada devido à convergência de necessidades e de tipos de dependência, que podem ser físicas e mentais. As dependências mentais, como Alzhaimer, exigem muito mais dos cuidadores que as dependências físicas.

Dada essas exigências e características especiais, os Centros Dia de acordo com Rodriguez Cabrero, podem ser definidos como: "un centro gerontologico terapéutico y de apoyo a la familia que presta atención integral a la persona mayor en situación de dependencia en regímen ambulatorial y de manera especializada" (RODRIGUEZ CABRERO, 2005, p. 10).

Desta citação, depreende-se a importância do enfoque global, a visão holística da interdisciplinariedade e o trabalho social de acordo com a necessidade de cada pessoa idosa dependente. Para tanto, são fundamentais a formação dos profissionais e a existência de recursos materiais e humanos e de sistemas de avaliação dos serviços, da satisfação dos usuários, dos cuidadores e demais profissionais.

No sistema europeu, conforme Rodriguez Cabrero (2005), as Instituições de Longa Permanência e o serviço de ajuda em domicílio têm maior oferta de serviços pela sua tradição. No entanto, isso não acontece nos Centros Dia. À semelhança do Reino Unido, estes têm suas raízes nos hospitais-dia. Nos países nórdicos e demais países anglo-saxões, o Centro Dia nasce como um dos recursos da área de Saúde, enquanto no Sul europeu, ele se apresenta como Centro Social e, na Europa continental, como espaço misto com maior peso na saúde (Holanda), e no social (França e Alemanha). Esse tipo de serviço tem sido lento. Rodriguez Cabrero afirma que:

[...] dentro del sistema asistencial para las personas mayores en situación de dependencia, es una exigencia ineludible estando integrado nuestro Estado de Bienestar en el espacio europeo de protección social o "modelo social europeo". Un espacio constituido por experiencias ancladas en sólidas tradiciones nacionales pero progresivamente abierto al aprendizaje y convergencia relativa en materia de políticas sociales (RODRIGUEZ CABRERO, 2005, p. 12).

Em algumas comunidades de Madri, o Centro Dia é, vale ressaltar, um dos recursos de natureza assistencial. É destinado às pessoas dependentes. No entanto, muitas vezes, eles são confundidos com os Centros Sociais, Clubes e outros Centros que são destinados 
às pessoas independentes, tendo como objetivo a integração social, a participação e a promoção do envelhecimento ativo com uma série de atividades à semelhança dos Centros de Convivência para idosos no Brasil.

Os Centros Dia devem fazer parte da rede de serviços sociais prestados às pessoas idosas, porém com função especial:

Em definitivo [eles] são, dentro da rede de serviços sociais, uma alternativa idônea para o aumento da qualidade de vida das pessoas idosas que têm uma situação de dependência e que precisam dos programas que lhes são prestados, como dos familiares que Ihes cuidam (RODRIGUEZ CABRERO, 2005 , p. 19 , tradução nossa). ${ }^{12}$

Ademais, simultaneamente, os Centros Dia apoiam as famílias com idosos dependentes e dão suporte aos cuidadores que, na maioria das vezes, não encontram apoio institucional e chegam a um alto grau de estresse, reconhecendo, assim, a importância também de cuidar de quem cuida. Daí necessita-se de uma rede de recursos estruturada para proporcionar atendimento adequado a quem está na ponta desse atendimento, que demanda muitas horas de trabalho, esforço intensivo e atenção contínua. Ainda conforme Rodriguez Cabrero (2005), quase $45 \%$ das pessoas dependentes recebem, por semana, mais de 40 horas de cuidados, dispensados pelo cuidador principal.

O Centro Dia contribui significativamente tanto para o idoso dependente como para a família, uma vez que a assistência poderá ser dada permanentemente e contínua, parcial ou temporal, de acordo com as necessidades do idoso e da família. A maior demanda é para a assistência permanente que concilia horário de trabalho e menor sobrecarga dos familiares, além de contribuir com a qualidade de vida do idoso, recuperando ou mantendo o seu grau de dependência funcional, retardando sua institucionalização e proporcionando-lhe qualidade de vida.

Há o Serviço de Atenção a Domicílio - SAD também oferecido às pessoas com dependência. Sua gestão fica a cargo do município e nela também é utilizado o mesmo sistema de contribuição do Estado e do usuário, que varia de acordo com o tipo de serviço prestado, carga horária e grau de dependência.

No modelo espanhol, as Comunidades Autônomas - CA aportam a rede de saúde e a rede residencial especializada e, ainda, a rede de serviços sociais comunitárias sob a gestão das prefeituras. Com isso, garantem a manutenção da rede de serviços comunitários

\footnotetext{
${ }^{12}$ Texto original: En definitiva, los Centros de Día son, dentro de la red de servicios sociales, una alternativa idónea para el aumento de la calidad de vida tanto de las personas mayores que tiene una situación de dependencia y que precisen de los programas de atención que se prestan a ellos, como de los allegados que se ocupan de su atención.
} 
que compreende: Ajuda em Domicílio, Centro Dia, Instituições de Longa permanência e serviços complementares, como prestações econômicas.

A rede de serviços públicos é fundamental, tanto pela sua extensa cobertura, quanto pela necessidade de que seja referência de qualidade e lócus da acreditação da rede de instituições privadas que prestam serviços. Sem uma rede público-privada estruturada e confiável, dificilmente ter-se-ão serviços de qualidade. Assim, essa rede requer todo um processo de avaliação para que possa ser instituição parceira entre governo e sociedade.

\subsection{DEPENDÊNCIA E CUIDADO NO CONTEXTO ESPANHOL}

A Espanha é um país cujo regime de bem-estar, mesmo sendo classificado como conservador, propõe-se a enfrentar riscos e agravos sociais contemporâneos no abstrato princípio de justiça social. No entanto, para Pino e Lara (2013):

La posibilidad de hacerlo depende del estatus laboral, en concreto de si participa en el marcado laboral, por lo que el propio sistema tiende a perpetuar las diferencias de estatus. La familia e, en especial, el varón, como sustentador principal, y la mujer, como ama de casa, son los principales encargados del bienestar (PINO; LARA, 2013, p. 27).

Essa é uma realidade ainda presente em várias partes do mundo e tende a se aprofundar no rastro do atual predomínio de políticas públicas socialmente restritas, de inspiração neoliberal.

Conforme Rodriguez Cabrero (2006), entre 1996 e 2007, com base nas recomendações do Defensor do Povo de implantar um sistema de proteção à dependência, surgiram numerosos debates políticos e científicos, culminando com um compromisso no Pacto de Toledo de se criar um seguro dependência, tendo como grande conquista a aprovação, em 2006, da Lei da Dependência. Essa Lei está inserida no quarto pilar do Estado de Bem-Estar, que é o da assistência social. De acordo com Moreno (2012), o quarto pilar refere-se ao acesso universal e descentralizado da rede básica de prestações de serviços, aos direitos a cuidados por parte dos dependentes e à promoção da autonomia destes. No entanto, tanto Moreno quanto Rodriguez Cabrero esclarecem que:

[...] desde 1990, el desarrollo del estado de bienestar se ha caracterizado por una contención del gasto y reformas de viabilidad, descentralización territorial y cesión de la provisión hacia la sociedad civil mercantil y no lucrativa. El tardío EB español, por tanto, un sistema universal incompleto, relativamente fragmentado en distintos niveles de protección social, y con insuficiente inclusión de personas que acumulan déficits sociales (apud MORENO, 2012, p. 64).

Os europeus, de modo geral, compartilham a opinião de que o Estado de Bem-Estar deveria proteger as pessoas contra os riscos provocados pela ineficiência do mercado, impedindo o aprofundamento e a extensão das desigualdades sociais. Tal Estado deveria 
proteger, ainda, as pessoas na velhice, evitando, assim, os riscos provenientes da dependência e garantindo-Ihes renda suficiente nessa etapa da vida.

Portanto, para esses autores e vários outros analistas, a dependência requer um trato especial, não só por constituir-se um dos grandes desafios para as políticas públicas, mas também pela demanda por serviços ser crescente e vir coincidindo com a crise do sistema de apoio informal.

De acordo com projeções demográficas (LIBRO BLANCO, 2005), em 2011, existiam, na Espanha 8.084.582 pessoas com 65 anos e mais de idade (constituindo 17,6\% da população), estando previstas, para 2016, 8.857.956 pessoas dessa faixa etária ou 18,5\% da população. Todavia, como já informado, a faixa dos idosos que mais cresce é a de idade acima dos 80 anos, em relação a qual há previsão de que, em 2016, superem 2,9 milhões, configurando uma tendência de que 3 em cada 10 pessoas acima de 65 anos superarão os 80 anos. E, como também já informado, é nessa faixa etária em visível reprodução em que mais se concentra a situação de dependência.

Com a Lei $\mathrm{n}^{\circ} 39$, de 14 de dezembro de 2006, de promoção de "la autonomía personal y atención a las personas mayores en situación de dependencia", também conhecida como Lei da Dependência, o sistema de proteção social espanhol assegurou direitos sociais para as pessoas em situação de dependência, que, além de contribuir para melhoria da qualidade de vida dessas pessoas, gerou emprego e renda.

$A$ atenção às pessoas com dependência, na Espanha, já vinha sendo desenvolvida por intermédio dos serviços sociais, de saúde e de previdência social, pois a Constituição espanhola de 1978, em seus artigos 49 e 50, já preconizava proteção às pessoas com deficiência e idosas e previa um sistema de serviços promovido pelo poder público para atendê-las.

A Lei no 39/2006, de Autonomia Personal y Atención a las Personas en Situación de Dependencia - LAPAD foi uma demanda dos setores sociais adeptos dessa causa, sindicatos, organizações de pessoas com deficiência e idosos, constituindo-se em uma grande conquista para a sociedade.

Vilá assim resume os princípios que articulam a LAPAD como:

a) derecho subjetivo de la ciudadanía; b) nivel mínimo de protección garantizado por la Administración General del Estado; c) doble objetivo: la promoción de la autonomía personal y la atención a las personas en situación de dependencia; d) igualdad y universalidad; e) prestaciones del Sistema para la Atención a la Dependencia incardinadas básicamente en el ámbito de los servicios sociales; f) gestión mixta público-privada; g) cooperación interadministrativa a través del Consejo Territorial de SAAD; $h$ ) prioridad por los servicios sobre las prestaciones económicas; i) financiación mixta (Estado, CCAA y usuarios) (VILÁ, 2013 apud LANGE, 2014, p. 53). 
A Espanha financia a atenção à dependência com recursos da Administração Geral do Estado (Federal) e das Comunidades Autônomas, porém, para Cobo (2007 apud LANGE 2014), o financiamento por intermédio de impostos deixa o sistema mais vulnerável, uma vez que não existe um imposto específico para determinado fim. A vantagem desse sistema de financiamento é a de ser mais equitativo do que o baseado em cotizações. No entanto, como desvantagem, ressalta o fato de que a dependência compete com outros gastos sociais na divisão dos recursos.

$\mathrm{Na}$ Lei da Dependência, destaca-se, dentre seus objetivos, a promoção da autonomia das pessoas em situação de dependência. Contudo, segundo Lange (2014), esta tem sido um dos grandes déficits do sistema espanhol porque vincula sua proteção ao grau e nível de dependência, resultando "inapropriado para las intervenciones de promoción de la autonomía, que no deben vincularse a la gravedad de la afección, sino a las posibilidades de logro de cada caso" (CASADO, 2011 apud LANGE, 2014, p. 12). E no caso particular de promoção da autonomia, a Lei da Dependência demonstra ausência de estratégias adequadas para potencializar a referida autonomia.

A esse respeito, Vilá (2013 apud LANGE, 2014) assinala que a própria lei apresenta:

[...] un sesgo hacia la dependencia, dejando a un lado la promoción de la autonomía. Las reformas que siguieron a la aprobación de la Ley incluso han acentuado la rigidez del sistema, la uniformidad de las prestaciones $y$, en definitiva, eliminando la capacidad de elección de las personas en situación de dependencia en lo que se refiere a la prestación económica en el entorno familiar. Un reflejo de esta deriva es que la prestación para promoción de la autonomía solamente representa el 2,28\% del total (VILÁ, 2013 apud LANGE, 2014, p. 60).

Em verdade, as 1,2 milhões de pessoas dependentes, num total de 8 milhões de idosos, contam apenas com 400 mil vagas destinadas ao grau III de dependência (estado grave) e 186.138 estão na lista de espera para serem atendidas em todo o país (SAAD, 2014).

A Lei da Dependência veio reforçar as ações em benefício das pessoas idosas que, antes, vinham sendo desenvolvidas nas comunidades autônomas e em locais com serviços básicos, de saúde, assistência social e alguns serviços assumidos pela Seguridade Social. Mas nem por isso ela deixou de ser vista como um instrumento fundamental para melhorar a situação dos serviços sociais no País.

Na opinião de Beltrán (2012), a Lei da Dependência proporcionou avanços que vieram acompanhados de profissionalização dos serviços, fundamentados na formação e na preparação de profissionais para dar atenção adequada e proporcionar melhor qualidade de vida às pessoas em situação de dependência e aos seus familiares. 
Com a crise capitalista iniciada em 2008, houve a necessidade de alterar a Lei da Dependência, priorizando o atendimento domiciliar e Centros Dia, residências (ILPI) somente para as pessoas no grau III de dependência, ou seja, aquelas (es) que estão em estado grave. As pessoas que estão com dependência moderada só deverão ser atendidas a partir de julho de 2015 (Ley 20/2012). Outra mudança foi em relação ao atendimento de estrangeiros: antes todos tinham assistência de saúde e outros serviços; mas, atualmente, só estão sendo atendidos os cidadãos em situação regular que estejam no país há cinco anos ou mais.

Para a pessoa com dependência ter acesso aos serviços oferecidos, ela deverá, primeiramente, passar por uma avaliação de sua situação de dependência, realizada pelo serviço social da comunidade autônoma, após o preenchimento de um "baremo" (formulário de avaliação). Tal formulário, a ser adotado em todo o território nacional, foi aprovado por decreto e determina que a análise da situação da pessoa com dependência compete a um profissional capacitado. Existe um catálogo contendo a relação de serviços, tais como: atenção residencial, centro de dia, centro de noite, ajuda em domicilio, teleassistência. Após a visita domiciliar, precedida de avaliação, é elaborado um Plano Individualizado de Atenção - PIA. E, em um segundo momento, de acordo com a avaliação da equipe responsável pelo atendimento, será disponibilizado o tipo de serviço a ser prestado de comum acordo com o beneficiário e sua família.

O IMSERSO mantém um Catálogo de Servicios y Prestaciones estabelecido pela LAPAD, o qual foi aperfeiçoado. Para tanto, foram adotadas, inclusive, a cooperação e a lealdade institucional acordada no Conselho Territorial de Servicios Sociales y del Sistema para Autonomia y Atención a la Dependencia. Foi também simplificada a normativa de desenvolvimento das ações estatais e mantido o Convênio Especial com a Seguridade Social para filiação dos cuidadores de idosos. No entanto, a permanência da contribuição é por conta do cuidador. Até 31 de dezembro de 2013, existiam 16.736 cuidadores contribuintes.

Ressalte-se que não faz parte do catálogo a prestação econômica vinculada ao serviço, que é a ajuda financeira concedida pelo Estado à pessoa dependente. Essa ajuda tem a finalidade de cobrir a demanda do beneficiário para contratar o serviço de que necessita ou pagar cuidadores. No caso de familiares serem os próprios cuidadores da pessoa idosa dependente, eles devem receber formação adequada para que possam desenvolver com qualidade o seu trabalho.

Todo o processo não poderá exceder 6 meses, entre solicitação e direito de acesso ao serviço, isso quando a pessoa é chamada para ser atendida, uma vez que a lista de 
espera para uma residência e para o centro dia leva, em várias Comunidades Autônomas, anos.

No que se refere ao financiamento, o usuário deverá pagar uma parte, que é definida pela Comunidade Autônoma. De acordo com a sua renda, poderá pagar mais ou menos que o valor do serviço. Apesar de esse serviço ser um direito, o co-financiamento é exigido pelo Estado.

Foi criado um sistema de transparência da informação com vistas a introduzir o modo real da gestão do sistema de dependência, com data da efetivação da prestação do serviço. Foi instituído, também, intercâmbio de informações entre as Comunidades Autônomas, porque existem pessoas que passam temporada em uma Comunidade e depois vão para outra. Com esse intercâmbio, a atenção à pessoa dependente e ao seu familiar passou a ser melhor administrada.

Para que os resultados dos serviços prestados fiquem evidentes e transparentes, foram realizadas duas avaliações no período de 2007-2011 e em 2012, sendo publicadas no Diário Oficial do Estado. A Espanha tem um governo Estatal (Nacional), com 17 Comunidades Autônomas, e cada uma tem sua capital e seus municípios.

Um dado interessante é o que diz respeito ao aumento do número de empregos nos serviços profissionais de atenção à dependência. Esse número supera as prestações econômicas de cuidados familiares, tendo seu efeito no emprego de profissionais de serviço social. Em janeiro de 2013, existiam 335.929 assistentes sociais com cobertura previdenciária e, em $1^{\circ}$ de dezembro do mesmo ano, essa cobertura atingiu 342.147 profissionais, revelando um incremento significativo de novos empregos nessa área. Esses dados demonstram que a dependência não gera só despesas, mas também emprego e renda.

Outra mudança significativa, e para pior, foi em relação ao não pagamento da Previdência Social dos cuidadores de pessoas com dependência. O Governo, por motivo de contenção de despesas, deixou de pagar a Previdência a 147 mil cuidadores. Atualmente, como já citado, somente 16,7 mil cuidadores são beneficiários da Previdência Social. A Espanha gastava $0,36 \%$ do PIB com os serviços para pessoas idosas antes da Lei da Dependência, mas atualmente, seu gasto é de $0,6 \%$ do PIB, enquanto a média europeia é de 1,2\%. Apesar da contribuição dos usuários para Seguridade Social ter aumentado de 8 a 9\%, não houve incremento de recursos para a Lei da Dependência. As prestações econômicas diminuíram em $15 \%$ de seu valor.

O valor da prestação do serviço é calculado pela capacidade econômica do usuário, entrando nesse cálculo a pensão e outras rendas, como aluguel. Como exemplo, temos o 
seguinte: quem tem uma renda de $€ 1.000$, paga $80 \%$ da sua renda. O IMSERSO calcula que, para 2017, se gaste $1 \%$ do PIB, o que corresponde a $€ 6$ milhões, aproximadamente, para atender as pessoas idosas em situação de dependência.

Em relação ao financiamento dos serviços, do total de $€ 2,6$ milhões disponíveis, $€ 1,3$ milhões, ou seja, 50\%, cabe à Administração Geral do Estado (Federal), enquanto os outros $50 \%$ são destinados às Comunidades Autônomas. Porém estas, além dos $€ 1,3$ milhões, gastam mais $€ 1,3$ milhões com cuidados de longa duração, despesa esta que já vinha sendo feita.

Se o município não tiver serviços para oferecer, ou se nas instituições públicas existentes não houver vaga, é concedido à pessoa prestação econômica para que ela pague uma instituição privada ou um cuidador.

As prestações econômicas obedecem a seguinte gradação: quando um familiar é o cuidador principal, ele recebe $€ 500$ se a dependência for grau III; $€ 300$ se forem grau II e $€ 100$ se for grau I. Quando a família decide por um serviço em uma instituição privada, o valor concedido é de $€ 800$.

Consta, na Lei da Dependência, a criação de um Conselho para a avaliação dos serviços e do sistema. Com base nessa disposição, foi criado o Conselho Territorial do Sistema para Autonomia e Atenção a Dependência, sendo alterado pelo Real Decreto-Ley 20/2012 para Conselho Territorial de Serviços Sociais e do Sistema para Autonomia e Atenção a Dependência, o qual tem permitido subsidiar o Estado com medidas de melhoria. O referido Conselho tem representantes do Governo da nação, das comunidades autônomas, dos municípios, dos conselhos municipais por intermédio de entidades; e conta, ainda, com seus próprios órgãos consultivos e de participação, a saber: Conselho Estatal das Pessoas Idosas, Conselho das Pessoas com Deficiência, Conselho Estatal das Organizações Não governamentais de Ação Social e Comitê Consultivo do Sistema de Dependência. $\mathrm{Na}$ composição do referido Conselho Territorial, terá como maioria os representantes das Comunidades Autônomas.

Todas as pessoas dependentes requerem uma intervenção continuada, ainda que não seja necessariamente permanente, baseada no apoio e nos cuidados. A atenção à pessoa com dependência está enquadrada, no âmbito dos serviços sociais (LIBRO BLANCO, 2005).

No entanto, existe uma forte relação da dependência e saúde, tais como: 
- Um problema de saúde que precise de atenção de saúde pode ser um fator desencadeante ou acelerador dos processos de dependência nas pessoas idosas de idade avançada;

- De forma ocasional, a pessoa dependente pode sofrer um processo agudo em seu estado de saúde que requeira uma atenção de saúde pontual;

- A existência de uma rede adequada para dar cobertura aos casos de dependência em sua vertente social não iria sobrecarregar o sistema de saúde de um grande volume de custos, que são, por outra parte, desproporcionais em relação à atenção que as pessoas dependentes necessitam (LIBRO BLANCO, 2005, p.24, tradução nossa). ${ }^{13}$

Torna-se evidente, portanto, a relação da saúde com a situação da dependência. Nessa relação, as intervenções realizadas têm contribuído significativamente para a prevenção da dependência nas idades mais avançadas, assim como para a melhoria dos hábitos de vida, impactando positivamente na longevidade. No entanto:

[...] a mais que frequente coexistência de enfermidades ativas complica a situação, até o ponto em que os casos de pessoas com maiores necessidades assistenciais, sejam aquelas em que a situação de dependência funcional coincide com as várias patologias e a instabilidade clínica (LIBRO BLANCO, 2005, p. 25, tradução nossa). ${ }^{14}$

Essa correlação, conforme Libro Blanco (2005), tem dado lugar ao conceito de "espacio sociosanitario":

[...] a este respeito, cabe destacar que a assimetria existente atualmente entre os serviços de saúde e os de assistência social é, precisamente, uma das dificuldades mais significativas para a proteção das pessoas com dependência, pois, enquanto a saúde constitui um serviço de caráter universal gratuito como direito legal para todos os cidadãos, os serviços sociais públicos têm um caráter afável e um desenvolvimento muito desigual. Organizar e coordenar ambos os tipos de serviços é essencial

\footnotetext{
${ }^{13}$ Texto original: Las personas dependientes requieren una intervención continuada, aunque no necesariamente permanente, basada en el apoyo y los cuidados. La atención de la dependencia se enmarca, por tanto, en el ámbito de los servicios sociales.

Sin embargo, existe una fuerte relación con el ámbito sanitario, pues:

Un problema de salud que precise atención sanitaria puede ser el factor desencadenante o acelerador de los procesos de dependencia en las personas de edad avanzada.

De forma ocasional, la persona dependiente puede sufrir un proceso agudo en su estado de salud que requiera una atención sanitaria puntual.

La existencia de una red adecuada para dar cobertura a los casos de dependencia en su vertiente social descargaría el sistema sanitario de un gran volumen de costes, que son, por otra parte, desproporcionados en relación con la atención que las personas dependientes necesitan.

${ }_{14}$ Texto original: la más que frecuente coexistencia de enfermedades activas complica la situación, de forma que los casos de personas con mayores necesidades asistenciales son aquéllos en los que la situación de dependencia funcional coincide con la pluripatología y la inestabilidad clínica.
} 
para proporcionar uma resposta integral e eficaz (LIBRO BLANCO, 2005, p. 25 , tradução nossa). ${ }^{15}$

A proteção social é concedida de acordo com a gravidade da dependência que é avaliada por equipe multidisciplinar das Comunidades Autônomas. Os graus de dependência têm avaliação médico-psicossocial.

As ajudas poderão ser em dinheiro, em serviços ou mistas. Em serviços, elas são pagas diretamente pelo setor público (ou parcerias com o setor privado) ou mediante cheque. A ajuda monetária tem a finalidade de compensar o cuidador informal ou possibilitar à família a contratação de um cuidador de sua escolha. Contudo, a ajuda financeira pode ser um incentivo para a mulher cuidadora renunciar a busca da oportunidade por emprego ou abandonar seu papel de cuidadora se a ajuda financeira não for satisfatória.

Como já salientado, a proteção destinada à pessoa idosa dependente contempla também a proteção ao cuidador, reconhecendo o tempo que excede ao cuidado, assim como a oferta de serviços de respiro ao cuidador, de informação e de formação para o cuidado.

Tanto nos Centros Dia como nas Residências (ILPI's) visitadas, em torno de $85 \%$ dos usuários têm Alzheimer ou outros tipos de demência e $80 \%$ dos institucionalizados estão em estado grave, requerendo recursos humanos qualificados para o cuidado.

Nas Residências visitadas, tanto as públicas como as privadas sem fins lucrativos, os quartos são individuais ou duplos, todos adaptados e com banheiros, existindo ainda em cada andar um banheiro específico para as pessoas que necessitam de um lugar mais espaçoso para o banho, como os acamados. Em todos os andares, existem espaços para televisão e lazer. As instituições contam com equipe interdisciplinar composta por médicos, enfermeiras, assistentes sociais, fisioterapeutas, psicólogos e, em algumas, terapeuta ocupacional, além de cuidadores que são chamados de auxiliares ou geroncultores.

Em todas as residências e Centros Dia visitados na Catalunha, a alimentação é terceirizada; apenas as saladas, os sucos e o lanche são feitos no local. Como é costume na Espanha, as refeições têm sempre o primeiro e segundo prato; os pratos principais são destacados por cores para diferenciar a dieta de cada usuário. Toda a alimentação é feita sob a orientação de nutricionistas e é aprovada pelo responsável higiênico que, por lei, tem que ser enfermeiro.

\footnotetext{
${ }^{15}$ Texto original: A este respecto, cabe destacar que la asimetría existente actualmente entre los servicios sanitarios y los sociales es precisamente una de las dificultades más significativas para la protección de las personas con dependencia, pues mientras la sanidad constituye un servicio de carácter universal y gratuito como derecho legal para todos los ciudadanos, los servicios sociales públicos tienen un carácter graciable y un desarrollo muy desigual. Organizar y coordinar ambos tipos de servicios es esencial para proporcionar una respuesta integral y eficaz.
} 
Uma das instituições visitadas, de Vila Nova, tem também Hospital Dia e atendimento de assistência social e saúde (sócio-sanitário) que depende do Departamento de Saúde e do Conselho de Bem-Estar, especificamente no que diz respeito à fisioterapia, à alimentação e ao vestuário. Uma das linhas de atuação desses Centros é voltada para atender pessoas que saem do hospital, necessitando de reabilitação e de cuidados específicos que não têm como receber em sua casa. Outros serviços, na fase final, são os cuidados paliativos destinados a toda a população idosa. No entanto, a maioria atendida são os internos da Residência (ILPI).

Os serviços do atendimento social e de saúde são custeados pela área de Saúde. No entanto, esses serviços são administrados por fundações, consórcios ou sociedades mercantis com ou sem fins lucrativos e os usuários podem ficar até 3 meses nessa unidade sem terem que pagar nada.

Cada Comunidade Autônoma tem sua legislação para funcionamento e fiscalização dos serviços prestados às pessoas idosas em situação de dependência. São realizadas chamadas públicas, para as quais concorrem instituições privadas com e sem fins lucrativos, visando equipar e administrar a instituição que já está funcionando. Os governos compram vagas - que são chamadas de vagas concertadas - para certo número de pessoas a serem atendidas. Há, ainda, o sistema por meio do qual o governo dá um cheque no valor de $€ 1.800$ aos muito dependentes e $€ 1.400$ aos dependentes severos. Com esse cheque, a pessoa procura a instituição de sua preferência, a qual pode ser colaboradora ou privada mercantil.

Existem dois tipos de Residências: as públicas, administradas por instituições públicas e as privadas com ou sem fins lucrativos. As administradas pelo setor público geralmente têm mais recursos financeiros e humanos. Nas residências privadas, os preços variam de $€ 2.000$ a $€ 2.500$, e as que ficam mais distantes do centro da cidade possuem preços entre de $€ 1.600 \mathrm{a} € 1.700$.

Para os Centros Dia, também são realizadas licitações a serem administradas por empresas públicas, ou privadas. Em um dos Centros visitados, observou-se que os valores do atendimento são tabelados por dia, uma vez que têm idosos que vão duas, três ou cinco vezes por semana. Neste Centro, a diária custa $€ 22,96$, enquanto, em outro Centro, o custo do atendimento é de $€ 800$ ao mês.

Tanto as ILPls como os Centros Dia têm Conselho de participação constituído por um presidente - que é o diretor da instituição -, secretário, administrador local, Conselho de Bem-Estar Social, 2 (dois) representantes dos residentes ou usuários dos Centros Dia, representantes das famílias, Conselho da Pessoa Idosa da Comunidade Autônoma e 1(um) 
trabalhador da instituição. As reuniões são realizadas por intermédio de convocação dos integrantes, que discutem gestão, serviços e temas que visam proporcionar o melhor atendimento possível.

Em todos os anos, as instituições são inspecionadas por órgãos do governo, apesar da existência do sistema de transparência com auditorias da própria instituição e da Comunidade Autônoma. Os inspetores costumam fazer avaliação dos serviços com os usuários, quando estes têm condições de participar, ou com seus familiares.

As atividades desenvolvidas nos Centros Dia são diversificadas e contam com a orientação de fisioterapeuta, terapeuta ocupacional e educador social, que geralmente dividem os usuários em grupos, de acordo com o estado de dependência de cada um. $\mathrm{O}$ Plano Individual de Atenção - PIA dos usuários é avaliado a cada dois meses pela equipe técnica e, caso não haja melhora do idoso, a família é chamada para que, juntos, elaborem outro plano.

A instituição de Vila Nova desenvolve também pesquisas científicas sob a coordenação de um médico geriatra. Algumas instituições de atenção à dependência estão aplicando um método de estimulação cognitiva nos idosos com demência e vem dando resultados.

Como o maior percentual de usuários apresenta demência, alguns Centros Dia utilizam como meio de comunicação uma agenda para cada idoso, por meio da qual seus familiares são informados sobre seu dia a dia. Outro meio de comunicação adotado é o telefone. São também realizadas duas reuniões ao ano com o psicólogo e os familiares dos idosos. Vale salientar que o maior número de pessoas idosas atendidos tem mais de 80 anos.

Os cuidadores que atendem os idosos em suas casas são orientados a como proceder no cuidado. Há grande preocupação estatal com a formação dos cuidadores, assim como com o tempo para o repouso dos mesmos. É pouco comum, mas já existem Centros que funcionam de dia, à noite e nos finais de semana para que o cuidador possa descansar. Há Centros em que a hora da saída é às $20 \mathrm{~h}$. Há instituições que desenvolvem atividades de ajuda mútua entre os cuidadores.

Tanto os Centros Dia como as ILPIs dispõem de serviços de cabeleireiro e de podologia, os quais são pagos à parte. Vale destacar que há uma grande demanda dos usuários da instituição por esse tipo de serviço. 
A cidade de Madri tem 3,3 milhões de habitantes. O município conta com 60 instituições próprias e 41 concertadas (que compram vagas), porém de gestão privada. São ofertadas 4.463 vagas e o tempo de espera para um Centro Dia é em torno de três meses.

Foi realizada visita a uma Residência e Centro Dia municipal, porém de administração privada com fins lucrativos.Verificou-se que se trata de única instituição exclusivamente destinada a pessoas idosas com dependência física. Nela, residem 36 pessoas idosas institucionalizadas, 12 por andar. E em cada andar, há sala de lazer e quartos duplos com banheiros adaptados; o refeitório fica em outro andar, comum a todos, assim como espaços para atividades. O prédio também possui cozinha, onde são feitas as refeições da Residência e do Centro Dia, e a lavanderia.

A instituição é considerada de excelência, tanto na gestão quanto nos serviços. Possui auditorias internas e externas, acompanhadas pelo município. Para a pessoa ter acesso a ela, tem que passar por todo um processo de avaliação médica e social.

Os usuários dos dois serviços dispõem de fisioterapeuta, assistente social, terapeuta ocupacional e uma equipe de auxiliares. Como parte dos recursos humanos da residência, existe, ainda, médico e enfermeira. Caso haja necessidade, o médico e a enfermeira podem prestar socorro ao usuário do Centro Dia. No entanto, existe uma rede de assistência social e de saúde que oferece toda cobertura às pessoas em situação de dependência.

Um dos serviços de custo elevado para o usuário é o de transporte. O Centro Dia dispõe de três vans adaptadas com 7 lugares e com um auxiliar para acompanhar os idosos. Esse serviço custa em torno de $€ 200$ a $€ 300$ por mês, dependendo do número de dias. A mensalidade pública fica entre $€ 800$ e $€ 900$; uma vaga privada no Centro Dia custa $€ 800$ acrescidos $€ 300$ de transporte e de comida; a contribuição do usuário das vagas públicas é de $27 \%$. A instituição que disponibiliza o serviço de transporte colabora substancialmente com a atenção e qualidade de vida do idoso. Tal instituição privada atende 240 mil pessoas, em convênio com a administração pública, no território espanhol que emprega 8.400 trabalhadores.

Outro Centro Dia visitado em Madri - desta vez, público de gestão privada - atende deficientes físicos, idosos com Alzheimer e de outros tipos de demência. O atendimento é realizado em espaços diferentes de acordo com o grau de dependência de cada usuário.

Os técnicos trabalham com frequência a estimulação da capacidade funcional dos idosos com pássaros, terapia ocupacional, fisioterapia, massagens, passeios externos e atividades intergeracionais. A atuação interdisciplinar é bem diversificada e conta com serviços de transportes. 
Contudo a rede de serviços assistencial é insuficiente, o que sinaliza para o fato de que haverá grande pressão sobre o sistema de cuidados, demandando infraestrutura adequada com equipamentos, recursos técnicos, humanos e financeiros. De acordo o Instituto de Mayores y Servicio Social - IMSERSO (2014), em janeiro de 2012, estavam na lista de espera, para conseguir prestação de serviço dentro do modelo da dependência, 305.941 pessoas e, em março de 2014 , esse montante se situava em torno de 186.138 , havendo uma redução de $39,16 \%$ - sendo este o número mais baixo desde a implantação da Lei da Dependência. As pessoas com dependência moderada tinham acesso aos serviços, mas, a partir da crise financeira em curso, houve alterações na lei: atualmente só ingressam as pessoas com dependência grave.

Sobre essa tendência, vale registrar o seguinte pronunciamento do Secretário-Geral das Nações Unidas:

[...] o crescimento do número de pessoas de idade exigirá importantes ajustes econômicos e sociais. Na maioria dos países, os governos deverão responder a esses novos desafios com políticas e programas apropriados que atendam as necessidades da sociedade em seu conjunto. Ele implica modificar perspectivas no que diz respeito à proteção social, aos direitos humanos e à coesão social (CEPAL 2008, p. 4). ${ }^{16}$

Realmente, o envelhecimento populacional constitui um grande desafio para os governos; no entanto, ainda não há uma predisposição dos gestores públicos de assegurar recursos para viabilizar serviços adequados às pessoas idosas, especialmente as dependentes que necessitam de cuidados de longa duração.

\subsection{INSTITUIÇÕES NÃO GOVERNAMENTAIS QUE DESENVOLVEM AÇÕES EM PROL DAS PESSOAS IDOSAS}

$\mathrm{Na}$ Espanha, são numerosas as instituições não governamentais e sem fins lucrativos que desenvolvem trabalhos com pessoas idosas. No entanto, a Unión Democrática de Pensionados y Jubilados - UDP foi uma das indicadas pelo orientador da Universidade de Alcalá de Henares pela sua capilaridade em âmbito nacional, pela sua atuação em Fóruns e Conselhos da União Europeia e, ainda, pela ampla parceria que mantém com instituições de ensino superior para fins de estudos e pesquisas. Outras instituições indicadas foram a Organização Iberoamericana de Seguridade Social - OISS, pelos trabalhos de capacitação que vem desenvolvendo nas áreas do idoso e pessoa com

\footnotetext{
${ }^{16}$ Texto original: "[el] crecimiento del número de personas de edad exigirá importantes ajustes económicos y sociales. En la mayoría de los países los gobiernos deberán responder a esos nuevos desafíos con políticas y programas apropiados que atiendan las necesidades de la sociedad en su conjunto. Ello implica modificar las perspectivas en lo que respecta a la protección social, los derechos humanos y la cohesión social.
} 
deficiência, na Ibero América, e a Fundação Pilares para la Autonomia, que se trata de uma instituição de estudos, pesquisa e formação de recursos humanos para o trato com as pessoas idosas, sendo uma referência nacional.

A UDP é uma associação sem fins lucrativos com 1,7 milhões de associados e 2.600 instituições. Criada em 1977, tem por fim, não só defender os direitos das pessoas idosas e pensionistas sem distinção de classe social, raça, ideologia política, credo filosófico ou religioso, como também fomentar o envelhecimento ativo e a intergeracionalidade como vias de desenvolvimento social. Trata-se de uma instituição politizada, com representação na Plataforma Europeia de Associações de Mayores, no Conselho Estatal de Personas Mayores; nos Conselhos Autonómicos, Provinciales y locales; na Federação Europeia de Mayores, no Foro Europeu de Mayores Activos e na Plataforma Española de Promoción del Voluntariado - PVE. Ainda tem parceria com universidades para fins de estudos, de pesquisas, de publicações de cartilhas educativas, de atividades intergeracionais e de convênios com o governo para administrar instituições de longa permanência, Centros Dia, teleassistência, vivendas tuteladas, Serviço de Atenção em Domicílio e serviços de comidas.

Onde, observa-se uma gama de atividades desenvolvidas pelos aposentados e pensionistas espanhóis, com ações voltadas para todas as idades. Na visita à sede da UDP, percebeu-se elevado nível de organização da instituição.

Além das instituições que administra, a UDP desenvolve trabalho voluntário, escola de formação de idosos ativos, eventos científicos e, anualmente, realiza assembleia geral com a junta diretora para prestar conta dos serviços realizados e dos gastos efetuados e apresentar projetos a serem realizados no ano seguinte. A cada 4 anos, a referida instituição realiza um congresso com delegados para eleger o presidente, em processo democrático.

A OISS desenvolve atividades à distância, em oito países iberoamericanos, tais como cursos sobre envelhecimento ativo, cuidadores de idosos para multiplicadores, cursos sobre dependência em geral destinados a pessoas com deficiência. Realiza também reuniões anuais presenciais.

Uma das entrevistas realizadas por esta pesquisadora foi com a direção da Fundação Pilares para la Autonomia Personal, a qual está desenvolvendo a técnica de "A atenção centrada na Pessoa -AICP" que, de acordo com Rodriguez (RODRIGUEZ, 2013), consiste em:

[...] promueve las condiciones necesarias para la consecución de mejoras en todos los ámbitos de la calidad de vida y el bienestar de la persona, partiendo del respeto pleno a su dignidad y derechos, de sus intereses y preferencias y contando con su participación efectiva (RODRIGUEZ, 2013, p. 74). 
Com base nessas informações, percebe-se que, no modelo AICP, os programas e os serviços devem ser todos planejados de forma que proporcionem o bem-estar da pessoa e que diminuam a sua dependência, promovendo condições de continuar com seus projetos de vida. Para o desenvolvimento desse trabalho, esta pesquisadora estudou normas e serviços de vários países europeus, inclusive fazendo visitas para verificar de que forma estão sendo desenvolvidas as ações centradas na pessoa. E, neste particular, comunga com a avaliação de Rodriguez, para quem:

O Serviço de atenção domiciliar (SAD) e de apoio ao entorno consiste em um programa personalizado, de caráter preventivo e reabilitador, em que se articulam um conjunto de apoios e técnicas de intervenções profissionais consistentes em provisão de serviços, atenção pessoal (física e psicossocial), gestão, funcionamento e adequação da unidade de convivência, fomento das relações sociais e apoio a família, prestado em seu domicílio e no entorno de uma pessoa adulta em situação de fragilidade, incapacidade e dependência (RODRIGUEZ, 2013, p. 80, tradução nossa). ${ }^{17}$

É importante frisar a importância da recomendação de que, nas proximidades da comunidade, sejam criados serviços que possam auxiliar na atenção domiciliar, como: centros de saúde, serviço de fisioterapia, transporte, centros de assistência social e atividades socioculturais. A rede de serviços estruturada no entorno do atendimento facilita o planejamento e o diagnóstico da ação a ser desenvolvida. Devem-se considerar também a acessibilidade no domicílio e entorno e, se possível, a oferta de ajudas técnicas que favoreçam o máximo de independência da pessoa idosa.

Segundo Rodriguez (2013), há evidência científica sobre:

- A eficácia da prevenção primária, secundária e terciária na compressão da morbidade e na redução da dependência;

- As diferenças interindividuais de dependência e envelhecimento;

- A influência do ambiente no bem-estar e na percepção de controle e qualidade de vida;

- Os bons resultados que se obtém ao intervir desde o enfoque das capacidades preservadas e no empoderamento para promover autonomia pessoal e reduzir o excesso de dependência;

\footnotetext{
${ }^{17}$ Texto original: El servicio de atención domiciliaria (SAD) y de apoyo en el entorno consiste en un programa personalizado, de carácter preventivo y rehabilitador, en el que se articulan un conjunto de apoyos y técnicas de intervención profesionales consistentes en provisión de servicios, atención personal (física y psicosocial), gestión, funcionamiento y adecuación de la unidad convivencial, fomento de las relaciones sociales y apoyo a la familia, prestado en el domicilio y el entorno de una persona adulta en situación de fragilidad, discapacidad o dependencia.
} 
- A efetividade das intervenções que se aborda praticando a interdisciplinariedade (incluindo a participação da pessoa e, no caso, sua família) em situações de incapacidade, envelhecimento e dependência;

- Os benefícios derivados da aplicação de enfoques de normalização e intervenção comunitária, tanto nos contextos domiciliares, quanto nos centros de atenção diurna e residências;

- Os resultados positivos que se evidenciam na participação, auto-estima e bem-estar subjetivo quando se têm em conta a opinião e o respeito aos desejos das pessoas destinatárias dos programas;

- A interconexão existente entre desenhos arquitetônicos e características ambientais de alojamento (casa própria, apartamentos ou casas com serviços, ILPI) e a produção de bem-estar nas pessoas;

- A satisfação que se registra o desempenho do papel profissional quando se aplica a atenção centrada na pessoa;

- Os bons resultados traduzidos em grau de satisfação e bem-estar das pessoas com necessidades especiais e de seus familiares cuidadores quando se aplicam estas diferentes medidas de apoio $e$ as incluem no desenvolvimento dos programas (RODRIGUEZ,Rodriguez, 2013, p. 14-16, tradução nossa). ${ }^{18}$

${ }^{18}$ Texto original: La evidencia científica producida por la que se ha constatado:

- La eficacia de la prevención primaria, secundaria y terciaria en la compresión de la morbilidad y en la reducción de la dependencia.

- Las diferencias interindividuales en los procesos de discapacidad y de envejecimiento.

- La influencia del ambiente en el bienestar y en la percepción de control y calidad de vida.

- Los Buenos resultados que se obtienen al intervenir desde enfoque de las capacidades preservadas y el empoderamiento para promover autonomía personal y reducir el exceso de dependencia.

- La efectividad de las intervenciones que se abordan practicando la interdisciplinariedad (incluyendo la participación de la persona y, en su caso, su familia) en situaciones de discapacidad, envejecimiento y dependencia.

- Los beneficios derivados de aplicar enfoques de normalización e intervención comunitaria tanto en contextos domiciliarios como en los centros de atención diurna y residencias.

- Los resultados positivos que se evidencian en participación, autoestima, y bienestar subjetivo cuando se tiene en cuenta la opinión y se respetan los deseos de las personas destinatarias de los programas.

- La interconexión existente entre diseños arquitectónicos y características ambientales de alojamiento (vivienda propia, apartamentos o viviendas con servicios, residencias) y la producción de bienestar en las personas.

- La satisfacción que se registra en el desempeño del rol profesional cuando se aplica la atención centrada en la persona. 
Os órgãos responsáveis pelas políticas sociais, em especial a do idoso, poderiam apostar nessa possibilidade de trabalho articulado e integrado com os órgãos que compõem a Seguridade Social. E um dos meios estratégicos para essa articulação é o segurocuidado.

\subsection{SEGURO-CUIDADO E A QUESTÃO DO FINANCIAMENTO}

Trata-se, essa modalidade de seguro, de uma alternativa de financiamento à dependência que, de acordo com Rodriguez Cabrero (2005), tem vários aspectos a considerar: a tradição de cada país, o entorno econômico e equilíbrio das contas públicas, o tipo de acordo entre os agentes sociais e econômicos e, finalmente, o tipo de contribuição do usuário. O financiamento das prestações é direcionado à cobertura de uma parte dos custos da dependência e não exclui o usuário de contribuir. Nenhum modelo europeu de proteção social da dependência tem uma cobertura ilimitada. O financiamento da dependência, nos diferentes modelos continentais e nórdicos, limita-se a garantir prestações monetárias, ajudas básicas ou prestações de serviços. O financiamento deve ser misto, uma vez que são várias as administrações públicas de proteção à dependência. A contribuição do usuário não deve exceder a certo valor de sua renda para não recair sobre ele o custo da carga do cuidado.

O modelo de financiamento deverá ser discutido entre o setor público e os agentes sociais. Existem dois modelos básicos de financiamento: o tradicional dos países nórdicos, financiado com impostos, e o modelo continental, financiado com cotizações sociais, tendo uma combinação mista de impostos e cotizações, em função da natureza contributiva e não contributiva da via de acesso às prestações.

O sistema de financiamento se articula como um modelo de seguro da Previdência Social, que financia as prestações da população dependente, tanto monetária, quanto em serviços com taxas contributivas para não sobrecarregá-la. No entanto, isso pode gerar resistência nas empresas, por ser um risco individual.

Mesmo que seja considerada um risco individual, a dependência não deve estar somente na esfera familiar. Os cuidados de longa duração extrapolaram essa esfera. Há que se considerar, ainda, as políticas de austeridade que sempre beneficiam os ricos e penalizam a população que realmente necessita de apoio, como no caso das pessoas em situação de dependência.

- $\quad$ Los buenos resultados que se obtienen en grado de satisfacción y bienestar de las personas con necesidades especiales y de sus familias cuidadoras cuando se aplican a éstas diferentes medidas de apoyo y se las incluye en el desarrollo de los programas. 
De acordo com Rodriguez Cabrero (2005), no modelo japonês, a única opção de apoio às pessoas em situação de dependência são os serviços. No modelo alemão, a liberdade é quase absoluta para escolher a ação desejada, podendo se estabelecerem formas intermediárias; e, no caso de Luxemburgo, restringem-se os serviços à liberdade de escolha, à medida em que aumenta a gravidade da dependência. As equipes de saúde e de assistência social, ou de avaliação da situação da dependência, são as que elegem entre serviços, prestação ou mesmo uma combinação determinada, de acordo com os desejos da pessoa dependente e de sua família.

De acordo com Lange (2014), na Alemanha, em 1994, foi aprovada a lei que regula o seguro de cuidados. Essa lei entrou em vigor em janeiro de 1995, sendo gradual a sua implementação. Começou, primeiramente, com o atendimento às pessoas com nível moderado de dependência. O que levou à edição da lei foi que muitos municípios se viram forçados a assumir parte dos gastos de atenção à dependência, por intermédio de subsídios sociais, uma vez que as pessoas recorriam à ajuda municipal por não terem condições financeiras para custear os cuidados.

O tema da dependência não é novo. Na Alemanha, já havia sido criada, em 1963, a prestação de serviços de caráter não contributivo destinado às pessoas em situação de dependência. Essa prestação assistencial passou de 165.000 beneficiários no ano de sua criação até alcançar 660.000 beneficiários em 1993 (STANTISTICHES BUNDESAMT, 2010 apud LANGE, 2014, p. 7). Com a introdução do seguro-cuidado, houve uma importante redução de gastos, que passou de $€ 9.000$ milhões, em 1994, para $€ 3.500$ milhões em 1997 (BUNDESREGIERUNG, 2004; TEOBALD, 2013 apud LANGE, 2014).

A Alemanha tem dois tipos de seguros, os quais, de acordo com LANGE (2014), têm suas peculiaridades:

El sistema público se rige por el principio de la solidaridad que se traduce en la determinación de las cotizaciones en función de los ingresos y en la concesión de prestaciones con independencia de los ingresos. El seguro privado no determina las cotizaciones en función de los ingresos pero sí en función del riesgo individual (LANGE, 2014, p. 17).

Conforme Lange (2014), o seguro alemão é regido pelo princípio da cobertura parcial em função de um catálogo de prestações de serviços, e não das reais necessidades das pessoas em situação de dependência. O seguro-cuidado é uma boa opção pela cobertura de serviços às pessoas em situação de dependência. No entanto, o ponto negativo é o de não ter ampla cobertura. A assistência de cuidados de longa duração é demandada em função das necessidades do usuário e a cobertura é parcial, não atende na totalidade. O segurado, além de pagar o seguro-cuidado, tem que contribuir com parte dos gastos com o cuidado. Na Alemanha, 51,1\% dos usuários desse seguro têm mais de 80 anos. Observa-se 
que, em um país desenvolvido, são inúmeras as dificuldades para implementação dos cuidados de longa duração - CLD e no Brasil, são poucos os que têm condições de pagar um plano de saúde que lhes dê cobertura de, pelo menos, home care. A situação é muito complexa. Para se ter ideia, na Alemanha, foram mais de 20 anos discutindo o tema e, no Brasil, sequer entrou-se na agenda política.

Quando reconhecida a situação da dependência, o sistema define o serviço a que se tem direito, pois combina o acesso universal às prestações de serviços com o objetivo de conter os gastos. O seguro de cuidados financia os serviços com as cotizações dos empresários e dos trabalhadores.

Para Lange, o princípio do financiamento por intermédio das cotizações é mais transparente do que as baseadas em impostos. Até 2005, o financiamento era paritário entre empresários e trabalhadores, mas, a partir de $1^{\circ}$ de janeiro de 2014 , entrou em vigor a lei para consideração da educação dos filhos que:

[...] transpone una sentencia del Tribunal Federal Constitucional. En la actualidad la cuotas es 2,05\% para asegurados con hijos (1,025 a cargo de trabajadores y empresarios respectivamente) y del 2,3 para aquellos que no tiene hijos (LANGE, 2014, p. 6).

Esse modelo está mais exposto à redução do número de cotizantes em decorrência do envelhecimento populacional e da crise econômica financeira.

No seguro alemão, como já mencionado, os serviços foram introduzidos de forma gradual. Em janeiro, começou a arrecadação; em 1ํ de abril de 1995, os serviços iniciaram com a atenção domiciliar; e, em julho de 1996, foram introduzidos os serviços nas instituições de longa permanência para idosos ILPI. Como o atendimento nas ILPI's só começou a ser ofertado um ano e meio depois da arrecadação, foi possível acumular um fundo de reserva. Quatro anos depois de implantado, o seguro privado de cuidados registrou um déficit de ingressos e gastos: $€ 820$ milhões em 2004, devido ao retrocesso do número de trabalhadores sujeitos a seguridade social e ao moderado incremento dos salários (LANGE, 2014).

Vale salientar que, por ser um sistema de cobertura parcial, a contribuição dos usuários é considerável. Conforme Schneider, "em 1999, 21\% do custo do serviço e em 2007, 27\%, e, em 2011, 33\%" (TEOBALD, 2013; ZUCHANDKE, 2011 apud LANGE, 2014).

Na Alemanha, a Lei do Seguro de Cuidados define a dependência de acordo com Lange:

São dependentes aquelas pessoas que, devido a una enfermidade ou deficiência física ou mental, não podem valer-se por si mesmas para realizar de forma regular as atividades de vida diária por um período de seis meses 
ou mais e que necessite de forma considerável de uma ajuda (artículo 14, Tomo XI del Código Social, apud LANGE, 2014, p. 9, tradução nossa). ${ }^{19}$

O seguro-cuidado alemão é quem determina a quantia financeira da prestação do serviço, o qual é determinado de acordo com a solicitação do beneficiário e o nível da dependência. Os cuidados englobam o asseio pessoal, a alimentação, a mobilidade e as tarefas domésticas. As delimitações das tarefas têm sido motivo de grande debate ainda em aberto.

Vale ressaltar, ainda, que o seguro-cuidado alemão divide-se em dois tipos de prestações de serviços, que são: atenção no entorno familiar e em residências (ILPI). Tanto os serviços prestados, como as ajudas financeiras, não são em relação às necessidades reais do beneficiário, e, sim, pelas quantias fixas; independente do caso, a cobertura é parcial e o segurado tem que contribuir com uma parte (SKUBAN, 2004, apud LANGE, 2014, p. 10).

Desde que foi implementado na Alemanha, o seguro-cuidado às pessoas com nível moderado de dependência passou de $40,1 \%$ para $56,1 \%$, enquanto a grande dependência (nível III) e a dependência moderada (nível II) caíram consideravelmente, passando de $16,6 \%$ para $11,9 \%$ e de $43,3 \%$ para $32 \%$, respectivamente. Esses dados demonstram a importância da prevenção que se reflete no retardo da dependência severa. Assim, penalizar a atenção aos dependentes moderados, como no caso da Espanha, para contenção de despesas, vai contribuir para acelerar a dependência para o estado grave e, consequentemente, haverá mais despesas, principalmente para as famílias, e aumento de cuidados.

Os usuários, para terem acesso aos serviços, deverão ser avaliados pelo serviço médico do seguro de enfermidades, que utiliza procedimento de avaliação com os mesmos critérios em todo país. O seguro público, em 2010, realizou 1.317.248 avaliações, 716.924 delas foram de novos beneficiários (BUNDESMINISTERIUM FÜR GESUNDHEIT, 2011b, apud LANGE, 2014).

Muitos seguros facilitam às pessoas uma cobertura. Contudo, essa facilitação constitui uma faca de dois gumes: por um lado, tem que existir a contribuição para se obter o serviço e, por outro, no caso da dependência, com o avançar da idade, as cotizações vão aumentando e os seguros, limitando o serviço.

\footnotetext{
${ }^{19}$ Texto original: "Son dependientes aquellas personas que, debido a una enfermedad o discapacidad física, psíquica o anímica no puedan valerse por sí mismas para realizar de forma regularlas tareas de la vida cotidiana para un período previsiblemente no inferior a los seis meses y que por ello necesiten de forma considerable o importante de una ayuda." (artículo 14, Tomo XI del Código Social, apud LANGE 2014).
} 
De acordo Rodriguez (2013), os bebês que nasceram na Espanha em 2013, quando alcançarem os 40 anos de idade, ao redor de 2050, viverão em um país mais envelhecido do mundo, com mais de 12 milhões de pensionistas. Muitos serão dependentes, implicarão altos custos para as famílias, e haverá um poder público com os cuidados de longa duração, requerendo-se que sejam desenhados sistemas sustentáveis de pensões e ajuda as pessoas em situação de dependência. Por isso sugere:

[...] debería ser un objetivo a largo plazo fortalecer la financiación de la dependencia tanto desde el plano público como en colaboración con las entidades aseguradoras, que pueden ser agentes que colaboren a sostener un nivel de bienestar elevado para el mayor número posible de ciudadanos (RODRIGUEZ, 2013, p. 80).

Rodriguez (2013) sugere, ademais para cobrir os riscos vinculados à dependência, soluções para as pessoas já dependentes:

Cabe recordar que las compañías del ramo vida pueden tanto ser gestoras de planes de pensiones, asegurar riesgos de vida a corto y largo plazo, conceder hipotecas y realizar hipotecas inversas.

Existen varias soluciones en el ámbito asegurador.las más conocidas son:

- Disponer de lo ahorrado previamente a través de planes de pensiones o de PPAs.

- Seguro de renta vitalicia. El tomador paga la prima con un inmueble y a cambio recibe una renta vitalicia para hacer frente a su nueva situación.

- Hipoteca pensión asegurada. Sin necesidad de vender su vivienda, el cliente opta por pedir un crédito hipotecario convencional y con el importe (o parte de éste) contrata una renta vitalicia.

- Seguro vivienda-pensión. El asegurado enajena la nuda propiedad de una vivienda y adquiere una renta de supervivencia inmediata. Por tanto se queda con el usufructo de la vivienda, pudiendo vivir en ella.

- Hipoteca inversa. El cliente recibe un capital o una renta vitalicia o temporal garantizando el pago con una hipoteca creciente sobre su vivienda.

- Ninguna de las soluciones es la panacea. De hecho todas tienen ventajas e inconvenientes, resalta la paradoja de que somos más ricos los europeos del sur (RODRIGUEZ, 2013, p. 81).

São inúmeras as sugestões do autor, porém, como ele cita, elas possuem suas vantagens e desvantagens, apesar de serem um grande filão para o mercado, merecendo serem bem pensadas as decisões a serem tomadas.

A Política de Cuidado na Europa forma parte das estratégias de proteção e de inclusão que vêm estimulando melhores práticas, com a permanência e o reforço da família, porém com extensão de responsabilidade do Estado.

A tendência de os países optarem por prestações econômicas em detrimento da contratação de serviços volta a jogar para a mulher a função de cuidar. Na atual conjuntura, 
como no caso da Espanha, são tantos os desempregados que se deveria buscar alternativas de emprego com os serviços destinados aos cuidados de longa duração.

\subsection{SERVIÇOS DESTINADOS AOS CUIDADOS DE LONGA DURAÇÃO NO BRASIL}

Sobre os serviços de cuidados às pessoas idosas dependentes, no Brasil, pouco se tem a explanar. Isso significa a breve referência que aqui se fará sobre eles. Sabe-se, com base em vivência profissional, em informações e em pesquisas, que esses serviços são escassos no país em virtude do número de Centros Dia existentes e da atenção domiciliar ainda não está disponível.

Felizmente, em relação às ILPI's, existem dados publicados resultantes da pesquisa intitulada "Características das Instituições de Longa Permanência", realizada pelo IPEA, coordenada por Camarano (2007/2010). As informações a seguir referenciam-se nos resultados dessa pesquisa e em outros estudos da referida pesquisadora, os quais também retratam a particularidade das disparidades socioeconômicas regionais prevalecentes no Brasil.

De acordo com a publicação mencionada, na região Norte - que é composta pelos Estados do Acre, Amazonas, Amapá, Pará, Roraima, Rondônia e Tocantins, e possui uma população de 15,8 milhões de habitantes, o percentual de idosos em relação à população total é de 5,5\%, sendo a mais baixa do País. Existem, nessa região, 49 ILPI's com 1.159 internos, sendo que, destes, $60 \%$ são do sexo masculino, $25 \%$ são semidependentes, $31 \%$ são dependentes e 10\% não são idosos. Das instituições pesquisadas, 15 são públicasmunicipais e 2 mistas, isto é, pública com gestão privada. A média de custo per capita é de $\mathrm{R} \$ 639,00$, sendo o maior gasto (55\%) com recursos humanos e, em segundo lugar, alimentação com 18\%. Dos recursos humanos, 22\% são cuidadores e 10\%, outros profissionais, tais como: médicos, fisioterapeutas, terapeuta ocupacional e dentistas. As instituições são fortemente apoiadas com recursos públicos, exceto nos Estados de Tocantins e Pará, nos quais a maior parte da receita provém da contribuição (pagamento) dos internos. Da população total de idosos, somente $0,3 \%$ vivem em ILPI. Na região, de acordo com os dados da PNAD 2003 (apud CAMARANO, 2007), vivem na região 90 mil idosos com dificuldades para atividades mais básicas de vida diária - AVD's.

Na região Centro-Oeste - formada pelos Estados de Goiás, Mato Grosso, Mato Grosso do Sul e Distrito Federal, com uma população de 13,04 milhões de habitantes, o cenário já começa a mudar para melhor. Existem 249 ILPI's (CAMARANOa, 2008) com $6,6 \%$ da população total, 5.529 internos e, destes, 59\% são homens. Quanto a sua personalidade jurídica, $66,1 \%$ são filantrópicas, isto é, privadas não lucrativas; $24,6 \%$, 
públicas; 4,8\% são privadas com fins lucrativos e 4,4\%, mistas. No Distrito Federal, 85,7\% dessas instituições são filantrópicas. Dos internos, 18\% não são idosos; 38,8\% são idosos dependentes; 29,3\% são semidependentes; 22\% têm serviços de saúde próprios; $69 \%$ recebem atenção do PSF e 93\% fazem uso do SUS. Os serviços de saúde, realizados em parceria com a rede pública, são: fisioterapia, 49\%; psicologia, 32,1\%; terapia ocupacional, $28 \%$ e fonoaudiologia, $10 \%$. O custo per capita desses serviços, na região, gira em torno de $\mathrm{R} \$ 479,24$ e, no DF, R\$ 726,0; desses, 44\% são destinados aos recursos humanos e $18,2 \%$, à alimentação. Dentre os recursos humanos, $22 \%$ são cuidadores. A média regional dos recursos provenientes dos residentes é de $31,3 \%$. Da população idosa, $0,6 \%$ reside em ILPI. Na região, residem 145 mil idosos com dificuldades para desenvolver as AVD's (PNAD, 2003 apud CAMARANOa, 2008).

A região Sul - constituída pelos Estados de Santa Catarina, Paraná e Rio Grande do Sul, com 27,38 milhões de habitantes, possui 8,3\% da população total de idosos e 693 ILPI's, com 15.422 internos. Destes, 61\% são mulheres; $13 \%$ não são idosos; $32 \%$ são semidependentes e 32,65\% dependentes. Quanto às instituições, 51\% são filantrópicas; $42,2 \%$ são privadas com fins lucrativos; $3,9 \%$ são públicas e $3,0 \%$, mistas. Quanto aos serviços oferecidos, $76 \%$ das ILPI's têm serviço médico próprio; $41 \%$ de serviços de fisioterapia, terapia ocupacional e psicólogo; $6 \%$ de fonoaudiologia e $41 \%$ recebem o PSF. O custo per capita das instituições varia entre $R \$ 500,00$ a $R \$ 1.000,00$; destes, $48 \%$ são destinados a pagamento de recursos humanos, dos quais $19 \%$ são cuidadores e $16 \%$ utilizados em alimentação. Quanto à proveniência de recursos, 67\% provêm dos residentes ou seus familiares. Apenas $0,7 \%$ dos idosos em relação à população total, vivem em ILPI (CAMARANO, 2008c). A Pnad 2003 (apud CAMARANO, 2008) aponta que 358 mil idosos da região apresentam dificuldades para desenvolver as AVD's.

Na região Nordeste - composta pelos Estados de Alagoas, Bahia, Ceará, Maranhão, Paraíba, Piauí, Pernambuco, Rio Grande do Norte e Sergipe, com 53,59 milhões de habitantes, 8,3\% da população são idosos. Nela, existem 302 ILPI's com 8.386 residentes, o equivalente a $0,2 \%$ dos idosos da região. Dos internos, $11 \%$ não são idosos, $25,1 \%$ são semidependentes e 40,5\%, dependentes. Das instituições, $81 \%$ são filantrópicas; $12,6 \%$, privadas com fins lucrativos e $6,0 \%$ são públicas. O custo médio per capita dessas instituições é de $R \$ 582$ em $70 \%$ delas, sendo que em $54,6 \%$ delas, o custo é inferior a $R \$ 500,00$ e, em $10 \%$ delas, é superior a $R \$ 1.000,00$. Quanto aos recursos, $52 \%$ deles são provenientes dos internos; $57,1 \%$ dispõem de serviços médicos: $27,2 \%$ possuem terapeuta ocupacional; 18,4 \%, serviços de psicologia; 13,9\%, serviço dentário e 90\% dos internos, quando necessitam, recorrem aos serviços do SUS. Dos recursos humanos, 25,7\% desenvolvem a função de cuidador (CAMARANO, 2008). De acordo com Pnad 2003(apud 
CAMARANO, 2008b), 358 mil idosos na região encontram dificuldades para desenvolver as AVDs.

A região Sudeste - constituída pelos Estados de Espírito Santo, Minas Gerais, Rio de Janeiro e São Paulo, com uma população de 80,35 milhões de habitantes, possui 10,9\% de idosos em relação à população total. Conta com 2.225 ILPI's, porém apenas 2.035 responderam aos questionários da pesquisa. Nessas instituições, são 53.374 internos, sendo $11 \%$ não idosos; $33,1 \%$ são semidependentes e $27,96 \%$, dependentes. Dos dependentes, $71 \%$ têm mais de 80 anos de idade, com a média de 0,6\% institucionalizados em relação à população total de idosos. Das instituições, 2,5\% são públicas, 67,0\% são filantrópicas e 9,7\%, privadas. Dentre os serviços oferecidos, $63,9 \%$ oferecem serviço médico; $61,3 \%$ de fisioterapia; $32,7 \%$ de terapia ocupacional e 23,3\%, serviços psicológicos. Como os serviços não são suficientes, 93,2\% recorrem aos postos do SUS e $46 \%$ usam serviços particulares. O custo médio per capita por residente dessas instituições é de $R \$$ 796,42 . Das ILPIs, $77,8 \%$ informaram ter gastos inferiores a $R \$ 1.000,00$, sendo que $44,3 \%$ das despesas estão entre $R \$ 500,00$ e $R \$ 1.000,00$ e $22 \%$, acima de $R \$ 1.000,00$. Dentre os gastos, $53,8 \%$ são destinados a recursos humanos e $12,4 \%$ à alimentação. Dos recursos humanos, $11,5 \%$ desenvolvem a função de cuidadores. Um dado diferenciado nessa região é que $56,8 \%$ oferecem cursos para cuidadores ou funcionários. Quanto aos recursos para manutenção das instituições, 58\% são oriundos dos residentes ou familiares; $17,5 \%$ são públicos e 14\% provêm de bazares e leilões; $8,3 \%$, de doações em dinheiro e 1,8\% de outras fontes. A maior fonte de financiamento público ocorre em São Paulo com 21,8\% e a de doações em dinheiro, em Minas Gerais com 10,7\% (CAMARANO, 2010).

No Brasil, as Instituições de Longa Permanência, quando criadas e, até há duas décadas, proporcionavam serviços de longa duração com caráter mais caritativo, ou seja, fornecendo cama e comida, sendo a maioria filantrópica. Atualmente, com os estudos mais avançados na área do envelhecimento, o perfil das instituições vem mudando e se adequando às novas legislações, dentre as quais destacam-se a RDC no 283/2005 da ANVISA e o Estatuto do Idoso.

Os governos, no entanto, não têm mais repassado recursos para revitalização das referidas instituições, tornando difícil adequá-las às normas vigentes. A atuação do Ministério Público Estadual, em especial nos Estados em que a Associação dos Membros do Ministério Público de Defesa do Idoso e Pessoas com Deficiência - AMPID tem representação, tem sido constante a fiscalização das ILPI's para que proporcionem serviços adequados e humanizados aos seus usuários. 
Além disso, ainda é muito cultural a família brasileira cuidar do idoso dependente e existe certo preconceito em deixá-lo em uma ILPI, como se esse ato caracterizasse abandono. Isso se se comprova na pesquisa de Camarano, a qual mostra que, em todas as regiões do País, há menos de 1\% dos idosos em ILPI's, apesar de ter demanda por esses serviços em razão do elevado número de idosos em situação de dependência e de as famílias não terem condições de prestar os cuidados adequados.

Essa cultura é também observada nas normas legais. Tanto na Política Nacional do Idoso - PNI e no Estatuto do Idoso - El, assim como na Constituição brasileira, é "obrigação da família [em primeiro lugar], da comunidade, da sociedade e do Poder Público assegurar ao idoso, com absoluta prioridade, a efetivação dos seus direitos”. Ademais, no El e na PNI, o atendimento ao idoso deve ser priorizado na família em detrimento do atendimento asilar e, somente quando este não for mais possível, deve-se recorrer a uma instituição, sendo importante lembrar que não existem ILPIs suficientes para a atual demanda.

Nesse contexto, os serviços em Centros Dia e a atenção domiciliar seriam alternativas nem sempre viáveis, pois, apesar desses serviços serem amplamente assegurados nas legislações em vigor, não conta com recursos disponibilizados pelo Governo, tornando-se imprescindíveis e urgentes medidas que assegurem uma política de serviços para os idosos em situação de dependência e que possam ser mantidos em seus lares.

Uma tematização imperiosa em relação aos cuidados de longa duração é a discussão do parágrafo único do art. 4 da PNI, que assim dispõe: "é vedada a permanência de portadores de doenças que necessite de assistência médica e de enfermagem permanente em instituições asilares de caráter assistencial". Na opinião da autora, é necessário criar Unidades de Cuidados Paliativos nas ILPIs, que tenham condições para tal serviço. O idoso deve viver e morrer dignamente e não ficar meses em UTIs que não são nada humanizadas.

Cabe ao Ministério do Desenvolvimento Social e Combate a Fome - MDS a implementação dos serviços destinados às pessoas idosas dependentes e independentes, tais como: Centros Dia, atenção domiciliar, institucionalização, centros de convivência, casalar. Esse Ministério, entretanto, só está desenvolvendo ações com enfoque na transferência de renda, com o Sistema Único de Assistência Social, que prevê os repasses per capita aos municípios de acordo com o número de habitantes.

A porta de entrada para os serviços de assistência social são os Centros de Referência de Assistência Social - CRAS ou os CREAS, que são os Centros de Referência Especializado de Assistência Social. 
Convém assinalar, ainda, que, no Brasil, não existe uma rede estruturada de proteção e de defesa dos direitos da pessoa idosa. São insignificantes os serviços oferecidos nas modalidades de Centro Dia. De acordo com a pesquisa realizada pela autora desta tese junto aos Conselhos de Defesa dos Direitos do Idoso, foi possível verificar que, no município de Belo Horizonte existe Centros Dia privados, mas ainda não estão cadastrados no CMI. No estado do Maranhão, há dois centros privados; Palmas possui um com fins lucrativos; o Paraná, em torno de 10 privados com fins lucrativos. No DF, um do Hospital Universitário e um com fins lucrativos.

De acordo com o Suplemento de Assistência Social da Pesquisa de Informações Básicas Municipais (MUNIC, apud CAMARANO, 2010, p.85), realizada em 2009, aproximadamente $4,1 \%$ dos municípios brasileiros contavam com Centros Dia financiados em algum grau pelo MDS. Vale salientar que o MDS vem apoiando Centros Dia para pessoas com deficiência porque o Brasil ratificou, em agosto de 2008, junto à Organização das Nações Unidas, a Convenção sobre os Direitos da Pessoa com Deficiência.

Os CREAS são destinados ao atendimento de alta complexidade, garantindo proteção integral ao indivíduo e às famílias que perderam seus vínculos familiares ou não têm mais condições de convívio familiar ou comunitário, estando disponíveis serviços aos idosos nas modalidades de atenção integral institucional, que, no caso, são as ILPI's, casa lar, república, casa de passagem, albergue e família acolhedora.

Fazendo uma análise comparativa entre Brasil e Espanha, que é considerado um país com regime de Bem-estar mediterrâneo e um dos países empobrecidos da União Europeia, o cenário mostra que, na Espanha, existe uma rede de serviços estruturada para as pessoas idosas em situação de dependência com serviços de atenção domiciliar, Centros Dia, ILPI, Hospital-Dia com unidade de cuidados paliativos, teleassistência e ajudas financeiras. Apesar da crise, mesmo com numerosas dificuldades, lá os serviços vêm sendo desenvolvidos de forma descentralizada com recursos do Governo federal e maior parte das Comunidades Autônomas. A política de cuidados de longa duração vem funcionando; a Lei da Dependência, mesmo com as dificuldades acarretadas pela crise estrutural e financeira do capitalismo, vem sendo implementada: mais de $50 \%$ dos idosos em situação de dependência têm algum tipo de cobertura. Além disso, não é só o Estado que arca com as despesas, mas também o usuário ou a família contribuem com o co-financiamento (co-pago) de acordo com a renda de cada um.

No Brasil, as ações destinadas aos cuidados de longa duração são desenvolvidas não como uma política destinada especificamente às pessoas em situação de dependência ou uma política de cuidado; tais ações são destinadas às pessoas idosas com ou sem 
dependência. No entanto, a Portaria MPAS/SEAS nำ 73/2001 elenca todas as modalidades de atendimento aos idosos dependentes e independentes. As ações desenvolvidas nos Centros Dia, no domicílio, são muito menos onerosas do que as ILPI e ainda contribuem para manutenção do idoso na família.

A ausência de recursos assegurados e as legislações brasileiras que dificultam os repasses de recursos para a implantação da atenção domiciliar, construção de centros dia, humanização e revitalização das IIPI's, impedem que os serviços sejam assegurados às pessoas idosas dependentes. Isso não ocorre com as pessoas com deficiência, que têm uma Convenção, como já citado, que Ihes assegura direitos e os Estados-partes da ONU devem cumpri-los.

Portanto, o Brasil ainda está anos-luz atrás de uma atenção aos cuidados de longa duração às pessoas idosas, apesar da existência do Benefício de Prestação Continuada, que é uma renda de caráter não contributivo; das ações desenvolvidas elo PSF e das ações pontuais em alguns municípios. Mas, isso é ainda insuficiente para um país que, daqui a 10 anos, será o sexto em população idosa do mundo. O Brasil não pode mais esperar para inserir os temas da dependência e do cuidado na agenda governamental. A sociedade é abastecida de leis, mas os entraves práticos e políticos são muitos para efetivá-las, o que faz com que a sociedade civil não tenha como garantir direitos. Contudo, há como ajudar na pressão política e no trabalho social para o alcance desse desiderato. 


\section{ARREMATES FINAIS E INFORMAÇÕES ADICIONAIS}

Definitivamente, o envelhecimento já não é apenas um "problema de Primeiro mundo". O que era de importância secundária no século XX tende a se converter em tema dominante no século XXI.

Kofi Annan

Ao longo desta tese, procurou-se demonstrar que o envelhecimento humano e populacional em curso é mundial e irreversível. E, em virtude disso, apesar de ele constituir uma conquista da humanidade, representa um grande desafio para as políticas sociais públicas.

Sendo essas políticas um produto das relações conflituosas entre Estado e sociedade - as quais, por sua vez, são determinadas pelo antagonismo estrutural entre capital e trabalho - seu desempenho perante esse desafio revela-se contraditório: ao mesmo tempo em que elas são movidas por pressões de movimentos sociais, para atender necessidades humanas postas pelo processo de envelhecimento, deve também incorporar demandas de um capitalismo em crise que luta pela sua reprodução. Logo, há um fundamental conflito de interesses a pressionar as políticas sociais públicas.

Esse foi o pano de fundo da pesquisa realizada em função desta tese que, para melhor compreender o desempenho das referidas políticas, destinadas aos idosos brasileiros, precisou analisá-las à luz das normativas internacionais, das quais o Brasil teve, em muitas delas, participação. Afinal, a pesquisa debruçou-se sobre uma temática de escopo supranacional. Além disso, para não ficar restrita a fontes indiretas, de caráter documental, a investigação contemplou atividades de coleta de dados e de informações em fontes primárias, que incluíram pessoas e instituições, não só no Brasil, mas também na Espanha, onde a experiência de trabalho com idosos é mais antiga. $E$ mais, fornece indicações dos dilemas comuns enfrentados na Europa ante as demandas do envelhecimento em meio às restrições colocadas pela crise capitalista também nesse continente, que foi pioneiro no campo do Estado Social e das políticas sociais públicas.

Dentre essas demandas, os serviços de cuidados às pessoas idosas dependentes foram eleitos como unidade de análise privilegiada da pesquisa. E é sobre eles que este arremate final irá se debruçar, trazendo informações adicionais.

Como é amplamente conhecida, a dependência é um dos fatores que afeta decisivamente a qualidade de vida das pessoas idosas. No Brasil, não existe uma política estruturada de atenção aos cuidados de longa duração. O País tem seguido as normativas internacionais da Organização das Nações Unidas e da Organização dos Estados Americanos, inserindo nas suas legislações as recomendações disponíveis. No entanto, 
existe uma grande distância entre as leis e a sua efetivação, o que, nesta tese, demonstrase pela oferta irrisória e problemática de serviços de cuidados às pessoas idosas dependentes.

Os resultados obtidos, por meio de pesquisa - de campo e documental - sobre os Conselhos de Defesa dos Direitos do Idoso, no Brasil, indicam que a maioria deles (90,5\%) foi criada na década de 90, levando, assim, à dedução de que o seu surgimento ocorreu na mesma época em que a Lei que instituiu a Política Nacional do Idoso foi sancionada. A partir de 1996, com a regulamentação da referida Política, foram criados os Fóruns Regionais; posteriormente, os Fóruns estaduais começaram a ser gradativamente criados, assim como ocorreu a implementação dos Conselhos nos Estados e nos Municípios. Há, portanto, um expresso aparato legal e institucional, em relação ao idoso, em vigor no País; mas, sua eficácia, comparada às suas finalidades, deixa a desejar.

$\mathrm{Na}$ pesquisa em apreço, chamam atenção as dificuldades de articulação e o distanciamento entre os Conselhos Estaduais e o Nacional, sobretudo e particularmente com o gestor nacional, demonstrando, segundo os entrevistados, uma relação classificada como: tumultuada, inexistente ou simplesmente parca. Mas, à medida que se avaliam os gestores estaduais da Política do Idoso e dos CEls, fica demonstrado que, apesar das dificuldades e da precariedade também verificadas, existe um pouco mais de aproximação entre os Conselhos estaduais com os municipais, predominando respostas positivas.

Quanto ao acompanhamento das normas internacionais sobre os direitos humanos da pessoa idosa no âmbito da Organização das Nações Unidas - ONU e da Organização dos Estados Americanos - OEA, é elevado o número de Conselhos $(85,7 \%)$, no Brasil, que não acompanham tais normatizações por não terem informações do CNDI, tampouco da Coordenação Nacional da Política do Idoso. E o mesmo acontece com as discussões sobre temas importantes de âmbito nacional. Quanto aos Conselhos, 80,9\% deles não têm informação, por exemplo, da designação de um relator do Conselho de Direitos Humanos da Organização das Nações Unidas para velar pelos diretos das pessoas idosas, revelando-se, mais uma vez, que essas informações estão sendo negligenciadas por parte dos órgãos nacionais.

Foi constatado, também, que o Órgão Coordenador da Política do Idoso nos Estados não vem discutindo com os Conselhos os serviços destinados às pessoas idosas em situação de dependência, o que constitui mais uma negligência injustificável por ser este um tema relevante que necessita de urgência no seu enfrentamento. Constata-se que, nas três esferas de Governo (federal, estadual e municipal, além do Distrito Federal), pouco tem sido realizado para fornecer suporte a essas pessoas idosas, cujo número tende a aumentar. 
Apenas quatro municípios brasileiros realizam projetos que beneficiam as pessoas idosas em situação de dependência; outros quatros informaram possuir serviços a esse público, mas em fase embrionária ou sendo desenvolvidos, em pequena escala, pelo Programa Saúde da Família - PSF.

Ao se procurar informação sobre a existência ou não de rede de serviços de saúde estruturada nos Estados observou-se que mais da metade dos entes estaduais afirmaram que esses serviços não existem (57,1\%); e, no que se refere à atenção domiciliar, a maioria é realizada por intermédio do PSF. Alguns Centros Dia funcionam como Centros de Convivência destinados aos idosos independentes.

No que tange à existência de Instituições de Longa Permanência para Idosos - ILPIs percebeu-se a urgente necessidade de acompanhamento dessas Instituições por parte dos Conselhos, em ação conjunta com a Vigilância Sanitária e o Ministério Público. Isso ocorre, pois ficou evidente que, tanto nas ILPI's, como nos Centros Dia e na atenção domiciliar, os serviços, na sua maioria, são precários, sugerindo a necessidade de atualização das suas estatísticas e de controle democrático.

Nas avaliações dos Conselhos, sobre a gestão da Política do Idoso no Brasil, nos âmbitos nacional, estadual, municipal e do DF, chama atenção a diversidade das respostas, - que não permitiu uma classificação mais precisa da sua situação. A maioria das avaliações foi negativa, identificando-se tal gestão como precária, inexistente, tímida, incipiente e ainda fraca. No entanto, no âmbito de município, alguns Conselhos se manifestaram de maneira mais positiva quanto a essa gestão, declarando que a mesma investe muito em projetos, ganhando visibilidade com a implantação das academias da Terceira Idade e dos Centros de Convivência, a criação da Coordenadoria da Política do Idoso e o processo de valorização da pessoa idosa, dentre outros.

Alguns Conselhos municipais sugeriram mudanças no sentido de ampliar as parcerias entre os Conselhos das demais esferas de Governo, principalmente com o Nacional, para avançarem nas propostas e nos projetos e, sobretudo, dar maior visibilidade às demandas e necessidades da pessoa idosa no cenário brasileiro. Verifica-se, assim, que tanto a gestão do CNDI como a Coordenação Nacional da Política do Idoso deixam muito a desejar em relação à integração com os seus congêneres saber: falta de recursos financeiros assegurados, de rede estruturada de proteção e defesa dos direitos da pessoa idosa, de efetivo controle democrático, de satisfatória interlocução da Coordenação Nacional com os gestores estaduais; de consistentes programas e projetos nas esferas infranacionais. 
A pesquisa também permitiu o conhecimento mais especificado das barreiras existentes para a implementação da legislação referente aos idosos no Brasil, a destinados às pessoas idosas em situação de dependência. Demonstra-se que, dentre outras providências, há necessidade urgente de formação continuada dos gestores da política do idoso nas três esferas de Governo, assim como a dos conselheiros, pois restou evidenciada a negligência com a garantia dos direitos das pessoas idosas, em especial das que se encontra em situação de dependência.

Dessa forma, a não oposição do Brasil à influência das decisões acordadas no âmbito internacional tem encontrado maiores obstáculos internamente. Mesmo assim, são dignas de nota incorporações, no ordenamento jurídico e nas práticas políticas brasileiras, de medidas de proteção ao idoso, que espelham preocupações supranacionais, tais como: no âmbito da Previdência Social, os idosos têm ampla cobertura de caráter contributivo; na Assistência Social, cobertura de caráter não contributivo; na Saúde, assistência pelo Sistema Único de Saúde. No entanto, é imperiosa a necessidade de se assegurar serviços às pessoas idosas em situação de dependência. A atenção às pessoas idosas no âmbito da Saúde é baseada no princípio da universalidade, porém se trata de uma universalidade que não alcança todos que necessitam de atenção especializada.

Torna-se imperioso, portanto, conforme indica a pesquisa, buscar alternativas que conciliem o crescimento econômico com o bem-estar social. Para tanto, a participação e a organização da rede de proteção e de defesa das pessoas idosas são primordiais para que se possa melhor administrar a transformação demográfica em curso e em progresso. De acordo com Harvey (2010):

[...] os mais avançados centros de acumulação de capital, como parte da Europa ocidental e o Japão, entraram numa linha de crescimento populacional negativo (com problemas decorrentes do envelhecimento das populações, que levam a todo tipo de problemas para acumulação do capital sustentada) enquanto o resto da Ásia, a América Latina e a África continuam a ter aumentos (HARVEY, 2010, p. 122).

Dentre os centros avançados, estão a Europa, que levou um século para sua população envelhecer, enquanto os países em desenvolvimento, como o Brasil, levaram apenas três décadas. O tema está presente no cenário atual, não havendo como ignorá-lo. Deve-se agir, buscando alternativas para se obter uma Previdência sustentável, serviços de saúde, educação e esporte que promovam um envelhecimento ativo e com qualidade de vida. Afinal, em 2025, o Brasil será o sexto país em população idosa do mundo.

No Brasil, existem leis que dão ampla cobertura à população idosa. Esse fato não é casual. Trata-se de conquistas, as quais, na sua maioria, foram frutos de mobilização da sociedade civil organizada, destacando-se os direitos inscritos na Constituição Federal 
vigente, promulgada em 1988. Mas, o conteúdo dessas leis, que expressam necessidades legítimas da sociedade, precisa ganhar concretude e coerência com a realidade que as demandaram.

Uma ilustração que respalda essa consideração é a recente criação do Decreto no 8.114, de 2013. O Brasil tem duas leis que asseguram os direitos sociais às pessoas idosas. No entanto, esse decreto de 30 de setembro, que estabelece o Compromisso Nacional para o Envelhecimento Ativo com vista à valorização, promoção e defesa dos direitos do idoso, afigura-se descabido, porque, se não existem recursos assegurados para a implementação da Política Nacional do Idoso, que contemplaria o disposto no Decreto, este tornar-se-á letra morta.

As pessoas, à medida que envelhecem, precisam de apoio em relação à renda e às oportunidades de trabalho decente para permanecerem ativas, além de serviços sociais e de saúde apropriados, destacando-se os cuidados de longa duração para as que se encontram em situação de dependência. A implementação de políticas públicas para atender essas novas e aumentadas demandas revela-se um desafio, principalmente, em um sistema socioeconômico em que essas políticas são consideradas "gastos", como o é no capitalismo de extração liberal. Assim, se "o capitalismo está fundado, tanto em termos de ideologias dominantes quanto nas práticas necessárias, sobre as liberdades individuais e as de participar de atividades especulativas de fazer dinheiro" (HARVEY, 2010, p. 132), fica evidente que o idoso será descartado por não ter a capacidade produtiva e o poder de consumo que têm os jovens e os empreendedores - mesmo que, os domicílios com pelo menos um idoso, 90,4\% tenham chefes ou cônjuges idosos (PNAD 2012) e ainda que o capitalismo já esteja lucrando com a velhice. Um exemplo são os seguros de vida na Espanha, a qual, superando a crise financeira, alcançou um crescimento de $3,48 \%$ em dezembro de 2013.

Constata-se, por fim, que, de acordo com a hipótese do trabalho desta tese, o Brasil é frequente interlocutor das discussões internacionais sobre envelhecimento e tem reconhecido a relevância do tema. Porém, no que se refere aos cuidados das pessoas em situação de dependência, ainda não inseriu na agenda governamental uma política de cuidados, nem tampouco assegura recursos para sua implementação. Com um documento juridicamente vinculante em âmbito internacional ou interamericano, como uma Convenção que assegure os direitos humanos às pessoas idosas, todos os países signatários das Nações Unidas e da Organização dos Estados Americanos serão obrigados a segui-lo e, assim, as pessoas terão seus direitos sociais assegurados. Em vista desse cenário, considera-se que a hipótese foi confirmada em parte, faltando a efetivação das ações contidas nas legislações brasileiras. 
A Lei da Dependência da Espanha, apesar de este País está enfrentando sérias dificuldades financeiras, veio reforçar as ações em benefício das pessoas em situação de dependência, com instrumentos para melhorar os serviços sociais no País, profissionalizando os serviços, formando recursos humanos, melhorando a qualidade do atendimento e contribuindo para um envelhecimento digno e com qualidade de vida.

$E$, para que as pessoas idosas possam desfrutar de uma velhice com qualidade de vida, é importante o investimento nas políticas relacionadas ao envelhecimento ativo de acordo com as recomendações da Organização Mundial de Saúde - OMS. Os exemplos de São Paulo e Belo Horizonte permitem vislumbrar uma noção da importância dos cuidados de longa duração e dos mecanismos que asseguram esses cuidados com comprometimento do gestor público.

Os idosos com limitações funcionais são os que apresentam maior incidência de pobreza, seguidos dos idosos com limitações instrumentais. Quanto às mulheres idosas, que são consideradas mais pobres que os homens, elas têm maior expectativa de vida e, consequentemente, são as mais afetadas pela dependência e pela ausência de cuidados de longa duração (PASINATO; KORNIS,2009, p.18).

A profunda crise estrutural, que vivencia, atualmente, o capitalismo, deixa, mais uma vez, o Estado abrindo as portas para a atuação do mercado nos cuidados de longa duração e colocando em segundo plano a proteção social às pessoas idosas dependentes. Em vista disso, urge a necessidade de a sociedade civil pressionar os governos para que seja inserida uma agenda de atuação na política brasileira com alternativas que assegurem os direitos humanos a esse segmento populacional. Não há mais como esperar. A dependência é considerada um risco social a ser enfrentado pelo Estado, pela família e pela sociedade. É agudizante o cenário atual, principalmente para os idosos de baixa renda, que são os mais afetados. Dentre os caminhos a perseguir para a conquista dos direitos, está a união de esforços entre governo e sociedade. E quanto mais organizada for a sociedade, maior poder de conquista se terá. 


\section{REFERÊNCIAS}

ALCOCK, Pete. A disciplina Política Social. Tradução livre de Potyara A. P. Pereira. In: ALCOCK, P. et al. The student's companion to social policy. Oxford: Blackwell, 1992.

ALVES, Rubem. Filosofia da Ciência: introdução ao jogo e suas regras. 16. ed. São Paulo: Loyola, 2011.

ASSOCIAÇÃO NACIONAL DE GERONTOLOGIA. Recomendação sobre Políticas Sociais para o Idoso nos anos 90. São Paulo, 1989.

BARBALET, J. M. Lisboa: Estampa, 1989.

BATISTA, A. S., Jaccoud, L.; AQUINO, El-moor. Envelhecimento e dependência: desafios para a organização da proteção social. Coleção Previdência Social. V. 28, 2008.

BELTRÁN, César Antón. Red de servicios sociales y atención a la dependencia. Madrid: Fundación Caser para la Dependencia, 2012.

BEHRING, Elaine; BOSCHETTI, Ivanete. Política Social: fundamentos e história. 9. ed. São Paulo: Cortez, 2011.

BOBBIO, Norberto. A Era dos Direitos. Tradução de Carlos Nelson Coutinho. 10. reimpressão. Rio de Janeiro: Elsevier, 2004.

BOSCHETTI, Ivanete. Avaliação de políticas, programas e projetos sociais. In: Serviço Social, direitos sociais e competências profissionais. Brasília: CFESS, 2010.

Os custos da crise para a política social. In: BOSCHETTI, Ivanete et al. (Org.) Capitalismo em crise, política social e direitos. São Paulo: Cortez, 2010.

BRASIL. Constituição da República Federativa do Brasil. Brasília: Senado Federal, 1988. Decreto $n^{\circ}$ 6.949, de 25 de agosto de 2008. Promulga a Convenção Internacional sobre os Direitos da Pessoa com Deficiência e seu Protocolo Facultativo, assinado em Nova York, em 20 de setembro de 2007. Lei $n^{\circ} 10.741$, de $1^{\circ}$ de outubro de 2003. Estatuto do Idoso. Brasília: Secretaria Especial dos Direitos Humanos, 2004.

. Lei no 8.842, de 4 janeiro de 1994. Dispõe sobre a Política Nacional do Idoso. Presidência da República. Lei n 8.742, de 7 de dezembro de 1993. Lei Orgânica da Assistência Social (LOAS).

. Lei no 6.179, de 11 de dezembro de 1974. Institui amparo previdenciário para maiores de setenta anos de idade e para inválidos, e dá outras providências. 
Decreto $n^{\circ}$ 4.227, de 13 de maio de 2002. Cria o Conselho Nacional dos Direitos do Idoso - CNDI e dá outras providências. Brasília: Presidência da República. Disponível em: $<$ www.planalto.gov.br>.

Decreto $n^{\circ}$ 5.109, de 17 de junho de 2004. Dispõe sobre a composição, estruturação, competências e funcionamento do Conselho Nacional dos Direitos do Idosos, e dá outras providências. Brasília: Presidência da República. Disponível em: $<$ www.planalto.gov.br>.

Lei no 12.435/2011. Dispõe sobre o Sistema Único de Assistência Social. Lei $n^{\circ}$ 12.213/2010. Dispõe sobre o Fundo Nacional do Idoso.

Ministério da Previdência Social. Informe de Previdência Social. Brasília, 2014.

Ministério da Previdência Social. Secretaria de Políticas de Previdência Social. Consulta a Coordenação de Estudos Previdenciários. Brasília, 2011.

Ministério da Previdência Social. A importância dos Regimes Próprios de Previdência Social para municípios. Brasília, 2011.

Ministério da Previdência Social. Panorama da Previdência Social Brasileira. 4. ed. Brasília, 2010.

REUNIÃO COM OS SETORES DE APOSENTADOS DAS CENTRAIS SINDICAIS, 5. Ata, Brasília, out./2013.

Ministério da Saúde. Portaria nº 2.528. Institui a Política Nacional de Saúde do Idoso, 2006.

Informe Brasil. CONFERÊNCIA REGIONAL INTERGOVERNAMENTAL SOBRE ENVELHECIMENTO NA AMÉRICA LATINA E CARIBE, II. Secretaria Especial de Direitos Humanos. Brasília, 2007.

Plano Nacional de Implementação das Deliberações. CONFERÊNCIA NACIONAL DOS DIREITOS DA PESSOA IDOSA, I. Conselho Nacional dos Direitos do Idoso. Brasília: Presidência da República, 2007.

. CONFERÊNCIA NACIONAL DOS DIREITOS DA PESSOA IDOSA, I. Construindo a Rede de Proteção e Defesa dos Direitos da Pessoa Idosa. Anais. Conselho Nacional dos Direitos do Idoso. Brasília, 2006.

. CONFERÊNCIA NACIONAL DOS DIREITOS DA PESSOA IDOSA, II. Avaliação da Rede de Proteção e Defesa dos Direitos da Pessoa Idosa: avanços e desafios. Anais. Conselho Nacional dos Direitos do Idoso. Brasília, 2009. 
. CONFERÊNCIA NACIONAL DOS DIREITOS DA PESSOA IDOSA, III. Envelhecimento e Políticas de Estado: Pactuar caminhos intersetoriais. Deliberações. Brasília: Conselho Nacional dos Direitos do Idoso. 2011.

Direitos Humanos: documentos internacionais. Secretaria Especial de Direitos Humanos. Brasília: Presidência da República, 2006.

. Informe Brasil. Brasília: Secretaria Especial de Direitos Humanos, 2007. Plano Mais Brasil PPA 2012-2015: agendas transversais-monitoramentos participativo: ano base 2012. Ministério do Planejamento, Orçamento e Gestão. Secretaria de Planejamento e Investimento Estratégico. Brasília, 2012.

. Resolução no 130. Brasília: Conselho Nacional de Assistência Social. 2005.

CAMARANO, Ana Amélia (Org.) Cuidados de longa duração para a população idosa: um novo risco social a ser assumido? Secretaria de Assuntos Estratégicos da Presidência da República/IPEA. Rio de Janeiro: IPEA, 2010.

Envelhecimento populacional brasileiro: bem-estar da população idosa e Seguridade Social. Seminário de Preparação para Aposentadoria. Brasília: ANFIP, 2010. . Características das instituições de longa permanência para idosos - Região Norte. Coordenação geral: Ana Amélia Camarano. Brasília: IPEA; Presidência da República, 2007. . Características das instituições de longa permanência para idosos - Região CentroOeste. Coordenação geral: Ana Amélia Camarano. Brasília: IPEA; Presidência da República, 2008a. . Características das instituições de longa permanência para idosos - Região Nordeste. Coordenação geral: Ana Amélia Camarano. Brasília: IPEA; Presidência da República, 2008b.

. Características das instituições de longa permanência para idosos - Região Sul. Coordenação geral: Ana Amélia Camarano. Brasília: IPEA; Presidência da República, 2008c.

Características das instituições de longa permanência para idosos - Região Sudeste. Coordenação geral: Ana Amélia Camarano. Brasília: IPEA; Presidência da República, 2010.

KANSO, Solange. Como as famílias brasileiras estão lidando com idosos que demandam cuidados e quais as perspectivas futuras? A visão mostrada pelas PNADs. In: CAMARANO, Ana Amélia (Org.) Cuidados de longa duração para população idosa. Rio de Janeiro: IPEA, 2010. 
CARVALHO, José Murilo. Cidadania no Brasil: o longo caminho. 12. ed. Rio de Janeiro: Civilização Brasileira, 2009.

CASADO, Demetrio. Aproximación a la dependencia funcional in La protección social de la dependencia en España. Documentación Social. Revista de Estudios Sociales y Sociología Aplicada, 141. Madrid: Caritas Española, 2006.

CEPAL - CELADE. Carta de San Jose sobre los derechos de las personas mayores de América Latina y el Caribe. Santiago do Chile, 2012.

Envejecimiento y desarrollo. Divisão de população. Notícias y actividades. Santiago do Chile, 10/03/2011.

. Los derechos de las personas mayores, mód. 2. Los derechos de las personas mayores en el ámbito internacional. Material de estudio y divulgación. Santiago do Chile, 2011.

. Observatório Demográfico - América Latina e Caribe. Envejecimiento poblacional. Santiago do Chile, 2011.

. División de población de la CEPAL. Los derechos de las personas mayores y los instrumentos internacionales de protección. Consideraciones generales. Santiago do Chile, 2008.

Los derechos de las personas mayores y los instrumentos internacionales de protección. Consideraciones generales. Santiago do Chile, 2008.

. Proyecto de resolución patrocinado por Argentina, Brasil, Chile, Cuba Jamaica, México e Panamá. Santo Domingo - República Dominicana, 2008.

REUNIÓN DE SEGUIMIENTO DE LA DECLARACIÓN DE BRASÍLIA, II. Buenos Aires, 2009.

REUNIÓN DE SEGUIMIENTO DE LA DECLARACIÓN DE BRASÍLIA, III. Santiago do Chile, 2009.

. Contribuição da CEPAL na implementação Regional do Plano de Ação Internacional de Madri sobre Envelhecimento (2008-2010). Santiago do Chile.

. Resolución $n^{\circ}$ 644. Santiago do Chile, 2008. Disponível em: <www.cepal.org.>. Acesso em: 28/08/2009.

REUNIÓN DE SEGUIMIENTO DE LA DECLARACIÓN DE BRASÍLIA. Rio de Janeiro: CEPAL, 2008.

. Declaração de Brasília. CEPAL, Santiago do Chile, 2007. 
Estrategia regional de implementación para América Latina y El Caribe del Plan de Acción Internacional de Madrid sobre el Envejecimiento. Santiago do Chile: Comissão Econômica para América Latina e Caribe, 2004.

REUNIÓN REGIONAL DE LA SOCIEDA CIVIL SOBRE ENVEJECIMIENTO.

Proceso de Seguimiento regional de la Segunda Asamblea Mundial sobre Envejecimiento, Madrid 2002 en América Latina y el Caribe. Grupo Interagencial sobre Envejecimiento. Santiago do Chile, 2003.

UNFPA. Perspectivas globales sobre protección de los derechos humanos de las personas mayores 2007-2009. Santiago do Chile.

COORDINACIÓN DE ORGANISMOS REGIONALES DE LA SOCIEDAD CIVIL DE AMERICA LATINA E EL CARIBE - CORV. Envejercer con Derechos "Princípios y Estrategias de La Sociedad Civil de América Latina y el Caribe”. Santiago do Chile, 2009. . Consejo del mercado común. Comunicado Conjunto de los Estados Partes del Mercado y Estados Asociados. REUNIÓN DEL CONSEJO DEL MERCADO COMÚNL, XXXIX. República Argentina: San Juan, 2010. Disponivel em <www.oas.org>. Acesso em: 20/06/2011.

CONFEDERAÇÃO BRASILEIRA DE APOSENTADOS E PENSIONISTAS. Disponível em: $<$ <ww.cobap.org.br>. Acesso em: 06/2011.

COBAP. Carta Compromisso. Camboriú, 2013. Recebido por e-mail.

DEAN, Hardley. Social Policy. Cambridge: Polity Press, 2006.

DEBERT, Guita. Imigrantes, Estado e família: o cuidado do idoso e suas vicissitudes. In: HIRATA, Helena; GUIMARÃES, Nadya Araujo. Cuidado e cuidadoras - as várias faces do care. São Paulo: Atlas, 2012.

Real-Decreto-Ley $n^{\circ}$ 20, de 12 de julho de 2012. Espanha: Madrid, 2012.

Real Decreto $n^{\circ}$ 1.051, de 31 de dezembro de 2013. Espanha: Madrid, 2013.

ESPING-ANDERSEN, Gosta; PALIER, Bruno. Los tres grandes retos del Estado del Bienestar. 2. impr. Barcelona: Planeta, 2011.

. Los tres grandes retos del Estado del bienestar. Barcelona: Planeta, 2010.

FAGNANI, Eduardo. Política Social no Brasil (1964-2002): Entre a cidadania e a caridade. Tese de Doutorado. Instituto de Economia da Universidade Estadual de Campinas. Campinas-SP: UNICAMP 2005. 
FERICGLA, Josep M. Envejecer una antropologia de la ancianidad. Barcelona: Anthopos, 1992.

FÓRUM NACIONAL da Sociedade Civil em Defesa de Direitos da Pessoa Idosa. Carta do Ceará II. Fortaleza, 2010.

FREITAS, Elizabete Viana. Demografia e epidemiologia do envelhecimento. In: PY, Ligia et. al. Tempo de envelhecer: percursos e dimensões psicossociais. 2. ed. Holambra, SP, 09/ 2006.

SEDEST. Governo do Distrito Federal. Portaria nํ 31. Brasília, 2013.

GOHN, Maria da Glória. Movimentos sociais e redes de mobilizações civis no Brasil contemporâneo. Petrópolis, RJ: Vozes, 2010.

Protagonismo da sociedade civil: movimentos sociais, ONGs e redes solidárias. 2. ed. São Paulo: Cortez, 2008. (Coleção Questões da Nossa Época).

HARVEY, David. O enigma do capital e as crises do capitalismo. Tradução de João Alexandre Peschanski. São Paulo: Boitempo, 2011.

HOFLING, Eloisa de Mattos. Cadernos CEDES, ano XXI, n. 55, nov./2001.

HUENCHUAN, Sandra. Perspectivas globales sobre la protección de los derechos humanos de las personas mayores, 2007-2013. Comisión Económica para América Latina y el Caribe (CEPAL), 2013.

La Protección de la salud en el marco de la demográfica y los derechos. Santiago do Chile: Centro Latino Americano y Caribeño de Demografía (CELADE) - División de Población de la CEPAL, Santiago do Chile, 2011.

IANNI, Octávio. Estado e planejamento econômico no Brasil. 4. ed. Rio de Janeiro: Civilização S.A., 1986.

INSTITUTO BRASILEIRO DE GEOGRAFIA E ESTATÍSTICA. Pesquisa Nacional de Amostra por Domicilio - PNAD 2008, 2010, 2012. Censo 2010.

IMSERSO, Revista Sesenta y Más, n. 325/2014. Madrid. Sistema para la Autonomía y Atención a la Dependencia-SAAD. Madrid, 2014. Sistema para la Autonomía y Atención a la Dependencia-SAAD. Avance Evaluación 2013. Sistema de Dependencia. Madrid, 2013. Libro Blanco, Madrid, 2005. 
JELIN, Elizabeth. Cidadania revisitada: solidariedade, responsabilidade e direitos. In: JELIN, Elizabeth; HERSHBERG, Eric (Orgs.) Construindo a democracia: direitos humanos, cidadania e sociedade na América Latina. São Paulo: EDUSP, 2006.

JESSOP, Robert. El futuro del Estado Capitalista. Madrid: Catarata, 2008.

LANGE, Miguel Montero. Análisis Comparados y Atención a La Dependencia en Alemania y España. Actas de la Dependencia, n. 10. Madrid: Fundación Caser para la Dependencia, 2014.

LEBRÃO, Maria Lúcia; DUARTE, Yeda Aparecida de Oliveira. Saúde e independência: aspirações centrais para os idosos. Como estão sendo satisfeitas. In: NERI, Anita Liberalesso (Org.) Idosos no Brasil: vivências, desafios e expectativas na terceira idade. São Paulo: Fundação Perseu Abramo, SESC/SP, 2007.

MARSHAL, T. H. Cidadania, classe social e status. Tradução de Meton Porto Gadelha. Rio de Janeiro: Zahar, 1967.

MASCARO, Alysson Leandro. Estado e reforma política. São Paulo: Boitempo, 2013.

MÉSZÁROS, István. Crise estrutural do capital. São Paulo: Boitempo,2009.

moraga, m. d. de prada; gonzáles, borge I. m. una aproximación al coste de la dependencia en España y su financiación. Universidad de Valladolid: Fundación Caser para la Dependencia, 2014.

MORENO, Luis. La Europa Asocial caminos hacia un individualismo posesivo? Barcelona, 2012.

MORENO, Luis. Ciudadanos precarios."La última red de protección social". Revista Del Ministerio de Trabajo y Asuntos Sociales. Barcelona, 2000.

MINAYO, Maria Cecília de Souza. O desafio do conhecimento pesquisa qualitativa em saúde. 12. ed. São Paulo: Hucitec, 2010.

MINAYO, Maria Cecília de S; ODÉCIO, Sanches. Quantitativo - Qualitativo: oposição ou complementariedade. Caderno de Saúde Pública. Rio de Janeiro, 1993.

MINISTÉRIO DA PREVIDÊNCIA SOCIAL. Secretaria de Políticas de Previdência Social. Consulta a Coordenação de Estudos Previdenciários, 2011.

A importância dos Regimes Próprios de Previdência Social para municípios.

Brasília, 2011. 
Panorama da Previdência Social Brasileira. 4. ed. Brasília, 2010. Barcelona: Ariel

Sociologia, 2000.

NETO, J. P. Introdução ao método da teoria social. Universidade Federal do Rio de Janeiro. São Paulo: Expressão Popular, 2012.

NETTO, Matheus Papaléo. Processo de envelhecimento e longevidade. In: NETTO, Matheus Papaléo. Tratado de Gerontologia. São Paulo: Atheneu, 2007.

ORGANIZAÇÃO DAS NAÇÕES UNIDAS. Asamblea General del Consejo de Derechos Humanos. Informe 24ํㅡㄹ Período de Sesiones. A/HRT/24/L.37/Rev. 1. New York, 2013. . Conselho de Direitos Humanos. Resolución no 20/24 - 20/24/HRC/24/L37/Rev.1. New York, 2013. . Consejo Económico y Social. Comisión de Desarrollo Social. 49º periodo de sesiones. New York, 2011. Consejo Económico y Social. Comisión de Desarrollo Social. 46ํperiodo de sesiones. New York, 2008. Informe Asamblea General. 68ํㅜ período de sesiones. Tercera Comisión, New York, 2013 Informe Secretario General 67/143 e 67/139. New York, 2013. Informe Asamblea General 67º período de sesiones. Tercera Comisión, New York, 2012. Informe Asamblea General 66 período de sesiones. Tercera Comisión, New York, 2011.

Conselho Econômico e Social da Organização das Nações Unidas. Informe E/cn.5/2011/L3 do. 49ํo período de sessão, ano 2011

. Comisión de Desarrollo Social. Informe del Consejo Económico y Social. 45은 periodo de sesiones. Principales acontecimientos en la esfera del envejecimiento desde la Segunda Asamblea Mundial sobre El Envejecimiento. New York, 2006.

. Plano de Ação Internacional Para o Envelhecimento. Tradução de Arlene Santos, revisão de português de Alkmin Cunha; revisão técnica de Jurilza Mendonça e Vitória Araújo. Brasília: Secretaria Especial dos Direitos Humanos, 2003.

Resolução no 65/189, 2012.

Resolução nº 67/139, 2012. 
Resolução nº 65/182. Assembleia Geral das Nações Unidas, 2010.

Resolução nº 46/91. Dispõe sobre os Princípios das Nações Unidas em favor das pessoas idosas. 1991.

Resolução no 45/106. Dispõe sobre o dia Internacional do Idoso. 1990

ORGANIZAÇÃO DOS ESTADOS AMERICANOS - OEA. AG/RES2562 (XLO/10), 2010.

. AG/RES 2.654 (XLI-O/11), 2011.

AG/RES 2.726 (XLIIO/12). 2012.

AG/RES.2.792 (XLIII-O/13). 2013.

- Consejo Permanente de la OEA. Comisión de Asuntos Jurídicos y Políticos.

CAJP/DHPM-100/13, Rev. 3, Washington, 2013.

- Consejo Permanente de la OEA. CAJP. Nota de la Presidenta Remitiendo el Documento Enviado por la CEPAL Referente a los Lineamientos para una Convención de los Derechos de las Personas Mayores/Edad. 24 de enero 2012.

. Consejo Permanente de la OEA. Comisión de Asuntos Jurídicos y Políticos. Informe sobre la Situación de las Personas Mayores en el Hemisferio y La Efectividad de los Instrumentos Universales y Regionales Vinculantes de Derechos Humanos Con Relación a la Protección de los Derechos de las Personas Mayores. OEA. Ser.G.CAJP/GT/DHPM14/11, Rev1, dec./2011.

Declaración de Compromiso de Puerto España. Quinta Cumbre de Organización de las Américas Puerto España, Trinidad y Tobago, 19 de abril de 2009. AG/RES.2455 (XXXIXO/09).

Protocolo de San Salvador, 1988.

ORGANIZACIÓN MUNDIAL DE LA SALUD y Milbank Memorial Fund. Programa sobre Envejecimiento y Salud. Hacia un consenso internacional sobre programas de cuidados de larga duración para las personas mayores. Tradución Guiomar Manso de Zúñiga Spottorno, oct./2002.

PASINATO, Maria Tereza de M.; KORNIS, George E. M. Textos para discussão n. 1.371. Rio de Janeiro: IPEA, 2009.

PEREIRA, Potyara A. P. Política social do segundo pós-guerra: ascensão e declínio. In: Revista Serviço Social \& Saúde. v. IX, n. 10, dez./2010.

. Do Estado Social ao Estado Anti-Social. In: PEREIRA, P. A. P. et al. (Orgs.) Política social, trabalho e democracia em questão. Brasília: Universidade de Brasília, 2009. 
Política social: temas \& questões. São Paulo: Cortez, 2008.

- Controle Democrático como garantia de direitos da pessoa idosa. Brasília: Secretaria Especial dos Direitos Humanos, Subsecretaria de Promoção e Defesa dos Direitos Humanos, 2007.

PESSOA, Izabel. A Política Nacional do Idoso frente ao fenômeno do envelhecimento populacional no Brasil: da formulação a implementação. Tese de doutorado. Brasília: Universidade de Brasília, 2007.

PRIETO, Cristina Vilaplana. Valoración Económica de las Medidas de Mejora del Sistema de Autonomía y Atención a La Dependencia Aprovados por el Real Decreto $n^{\circ}$ 20/2012, de 13 de Julio-Fundación Caser para la Dependencia. Universidade de Murcia y FEDEA, 2012.

PINO, Eloísa Del; LARA, Ma Josefa Rubio. El estúdio comparado de las transformaciones del Estado de bienestar y las políticas sociales; definiciones, metodología y temas de investigación. In: Los Estados de bienestar em la encrucijada-políticas sociales en perspectiva comparada. Madrid: Tecnos (Grupo Anaya S.A.), 2013.

PISON, Jose Martinez de. Políticas de Bienestar: un estudio de los derechos sociales.

Madrid: Tecnos, 1998.

POULANTZAS, Nicos. O Estado, o poder, o socialismo. Rio de Janeiro: Graal, 1981.

Biblioteca de Ciências Sociais, série: Política, v. 19.

PREFEITURA MUNICIPAL DE BELO HORIZONTE. Pensar BH/ Política Social, n. 31 , mar./2012. Belo Horizonte, Câmara Intersetorial de Políticas Sociais. 1. Política Social 2. Administração 3. Prefeitura de Belo Horizonte.

PREFEITURA DO MUNICÍPIO DE SÃO PAULO. Documento Nortedor Programa Acompanhante de Idoso. São Paulo: 2012.

QUIVY, Raymond e Campenhoudt. Manual de Investigação em Ciências Sociais. Tradução: João Minhoto Marques, Maria Amália Mendes e Maria Carvalho. Lisboa: Gradiva, 2008.

REVISTA ESPAÑOLA DE GERIATRIA E GERONTOLOGIA. Madrid: Sociedad Española de Geriatria y Gerontologia, v. 37, suplemento 2, ago./2002.

RODRIGUEZ CABRERO, Gregorio. Los Sistemas Públicos Europeos de Atención a la Dependencia, In: RODRIGUEZ, Pilar; VILÁ, Mancebo A. (Coord.) Modelo de Atención Integral y Centrada en la Persona - Teoría y Práctica en Ámbitos del Envejecimiento y la Discapacidad. Madrid: Fundación Pilares para La Autonomía Personal, 2014. 
Tendencias Recientes en el desarrollo de los Sistemas Públicos Europeos de Atención a la Dependencia. In: Actas de la dependencia. Madrid: Fundación Caser 01, mar. 2011.

- La protección social de la dependencia En España. Un modelo sui generis de desarrollo social de los derechos sociales. Política y Sociedad, v. 44, n. 2, p. 69-85. 2007.

- La protección Social a las personas mayores en situación de dependencia en España en el contexto de las políticas europeas de cuidado de larga duración. In: Actores Sociales y reformas del bienestar. Consejo Superior de Investigaciones Científicas. Unidad de Políticas Comparadas - UPC. Madrid, 2005.

et al. In: Los Centros de Día. Aproximación a la experiencia internacional y española. Fundación Pfizer. Madrid, 2005.

Por un nuevo contrato social: el desarrollo de la reforma social em el ámbito de la Unión Europea. In: Unión Europea y Estado Del Bienestar. Luis Moreno (copilador). Consejo Superior de Investigaciones Científicas-Instituto de Estudios Sociales Avanzados.Madrid, 1997.

RODRIGUEZ, Pilar Rodriguez; VILÁ, Antoni Mancebo. Modelo de Atención Integral y Centrada en la Persona, Teoria y Práctica en Ámbitos del Envejecimiento y la Discapacidad. Fundación Pilares para la Autonomía. Madrid: Tecnos (Grupo Anaya S.A.), 2014.

RODRIGUEZ, Pilar Rodriguez. La atención integral centrada en la persona. Madrid:

Fundación Pilares para la autonomia personal. Colección Papeles de La Fundación № 1, 2013.

RODRIGUEZ, Manuel Álvarez. Soluciones para Cubrir Riescos-Vinculos a la Dependencia. In: Actas n. 10. Madrid: Fundación Caser, 2013.

SANTOS, Wanderlei Guilherme. 1979 - Cidadania e Justiça: a política social na ordem brasileira. Rio de Janeiro: Campus, 1970.

SILVA, Enid Rocha Andrade. Texto para discussão nº 1.378. Brasília: IPEA, 2009.

SOUZA, Celina. Política pública: uma revisão da literatura. In: Sociologias, ano 8, n. 16, jul.dez./2006, p. 20-45.

TAYLOR-GOOBY, Peter (Org.) Welfare States under pressure. London/Tousand Oaks/New Delhi: Sage, 2003. 


\section{ANEXOS}

ANEXO I - VISITAS REALIZADAS

CENTRO DIA e Residência Instituição: Sant Antoni - L'Onada (público com gestão privada) - Vila Nova - Barcelona (27/03).

CENTRO DIA e Residência Porta - Fundação Vella Terra (público, com gestão privada) Barcelona (27/3).

CENTRO DIA e Residência Masbau e Los Joseps - Fundação Privada Sant Antoni Abat (privado mas com plazas concertadas) - Villanova (28/03).

CENTRO DIA e Residência Santa Engrácia (público com gestão privada - EULEN) Madri (10/04).

CENTRO DIA ASISPA - Asistencia a Personas Mayores (público com gestão privada) Madri (09/04).

SERVIÇO DE ATENÇÃO DOMICILIAR - SAD - ASISPA (público com gestão privada) Madri (09/04).

SERVIÇO DE TELEASISTÊNCIA - ASISPA - Madri (09/04).

CENTRO DIA e São José de Villareal para idosos com demência e deficiência física (público com gestão privada - La Casona) - Madri (24/04).

CENTRO DIA Atalaia - Consórcio Gallego (público com gestão pública) - Vigo (02/05).

CENTRO DIA Beiramar AFAGA para idosos com demência (público com gestão privada) Vigo (02/05).

CENTRO DIA Parque Castrelos (privado algums vagas públicas) - Vigo (02/05).

UNIÓN DEMOCRÁTICA de Pensionista y Jubilados - UDP. 


\section{ENTREVISTAS}

ANA MOHEDANO - Organização Iberoamericana de Seguridade Social - OISS - Madri (31/03).

JESUS NORBERTO FERNÁNDEZ MUÑOZ - Subdiretor General Adjunto de Análisis Presupuestario y de Gestión Financeira do Instituto de Mayores y Servicio Social IMSERSO/Ministério de Salud - Madri (25/03).

ANTONI VILÁ - Professor Pesquisador em Política Social da Universidade Autônoma de Barcelona - Barcelona (27/03).

EULÁLIA CUCURELL - Presidente da Fundação Alzheimer da Catalunha e trabalhadora social responsável pelos centros próprios do Departamento de Bem-Estar Social e Família da Generalitat da Catalunya - Barcelona (28/03).

PILAR RODRIGUEZ - Presidente da Fundação Pilares - Madri (03/04).

DEMETRIO CASADO - Especialista em Política Social, educativa e sanitária, funcionário público aposentado do Ministério do Trabajo, diretor técnico do Real Patronato sobre Discapacidad - Madri (07/04).

JUAN DE LA TORRE VIDAL - chef del Departamento de Centros de Dia y Residenciales Director General de Mayores y Atención Social de Ayuntamiento de Madrid - Madri (10/04). 